UNIVERSIDADE DE SÃO PAULO

FACULDADE DE ECONOMIA, ADMINISTRAÇÃO E CONTABILIDADE DEPARTAMENTO DE CONTABILIDADE E ATUÁRIA

PROGRAMA DE PÓS-GRADUAÇÃO EM CONTROLADORIA E CONTABILIDADE

\title{
HEGEMONIA DO DISCURSO CIENTÍFICO CONTÁBIL NO BRASIL
}

\author{
Iracema Raimunda Brito Neves Aragão
}

Orientador: Prof. Dr. Gilberto de Andrade Martins 
Dr. Marco Antonio Zago

Reitor da Universidade de São Paulo

Dr. Adalberto Américo Fischmann

Diretor da Faculdade de Economia, Administração e Contabilidade

Dr. Gerlando Augusto Sampaio Franco de Lima

Chefe do Departamento de Contabilidade e Atuária

Dr. Andson Braga de Aguiar

Coordenador do Programa de Pós-Graduação em Controladoria e Contabilidade 


\section{HEGEMONIA DO DISCURSO CIENTÍFICO CONTÁBIL NO BRASIL}

Tese apresentada ao Programa de PósGraduação em Controladoria e Contabilidade do Departamento de Contabilidade e Atuária da Faculdade de Economia, Administração e Contabilidade da Universidade de São Paulo, como requisito parcial para a obtenção do título de Doutor em Ciências.

Orientador: Prof. Dr. Gilberto de Andrade Martins

Versão Corrigida

(versão original disponível na Biblioteca da Faculdade de Economia, Administração e Contabilidade) 
Está autorizada a reprodução e divulgação, total ou parcial desta obra, por quaisquer meios convencionais ou eletrônicos, para fins de estudo e pesquisa, desde que seja citada a fonte.

FICHA CATALOGRÁFICA

Elaborada pela Seção de Processamento Técnico do SBD/FEA/USP

Aragão, Iracema Raimunda Brito Neves

Hegemonia do discurso científico contábil no Brasil / Iracema

Raimunda Brito Neves Aragão. - São Paulo, 2016.

$179 \mathrm{p}$.

Tese (Doutorado) - Universidade de São Paulo, 2016.

Orientador: Gilberto de Andrade Martins.

1. Contabilidade - Pesquisa 2. Discurso científico 3. Hegemonia 4. Argumentação I. Universidade de São Paulo. Faculdade de Economia, Administração e Contabilidade. II. Título.

$$
\text { CDD - } 657.07
$$


ERRATA 
Nome: Aragão, Iracema Raimunda Brito Neves

Título: Hegemonia do Discurso Científico Contábil no Brasil

Tese apresentada ao Programa de PósGraduação em Controladoria e Contabilidade do Departamento de Contabilidade e Atuária da Faculdade de Economia, Administração e Contabilidade da Universidade de São Paulo, como requisito parcial para a obtenção do título de Doutor em Ciências.

Aprovada em:

\section{Banca Examinadora:}

Prof. Dr. Gilberto de Andrade Martins

Instituição Universidade de São Paulo Assinatura:

Prof. Dr. Gerlando Augusto Sampaio Franco de Lima

Instituição Universidade de São Paulo

Assinatura:

Prof. Dr. Valdir Heitor Barzotto

Instituição Universidade de São Paulo Assinatura:

Prof. Dra. Márcia Martins Mendes de Luca

Instituição Universidade Federal do Ceará Assinatura:

Prof. Dr. Romualdo Douglas Colauto

Instituição Universidade Federal do Paraná Assinatura:

São Paulo (SP), __ de ___ de 2016. 
Dedicada a ...

Gumercindo das Neves (in memoriam) Ionete Neves dos Anjos (in memoriam)

Masayuki Nakagawa (in memoriam) 


\section{AGRADECIMENTOS}

Agradecer é a forma mais bela de reconhecer que nos tornamos maiores quando entendemos que sozinhos somos incompletos, somos pequenos... Penso que a experiência com o outro, sob qualquer circunstância, é motivo maior de agradecimento por causa do aprendizado que nos proporciona. Todavia, é necessário que consigamos extrair das relações que nos desafiam a força que precisamos para lutar, vencer e nos tornarmos humanamente melhores... É preciso viver das ternas lembranças que se cravam em nosso coração, é preciso se colocar no lugar do outro, é preciso render graças a Deus pelo dom da fé, da esperança e do amor.

Estas verdades estão comigo desde a graduação, mas se tornaram ainda maiores, no meu processo de doutoramento. Assim, agradeço a Deus por se fazer presente em minha vida por meio de pessoas muito especiais:

Meu esposo, Raelson Aragão, meu filho Lucas Aragão e minha mainha, Idalva Neves. Meus sobrinhos Anderson Neves e Vinicius Neves; meus irmãos e minhas irmãs; cunhadas e demais sobrinhos e sobrinhas.

Meus mestres, aqueles que me ensinaram muito além do que há de mais preciso nas teorias e técnicas: Prof. Dr. Gilberto de Andrade Martins, o meu orientador, sinônimo de competência, criticidade e apoio sem os quais esta conquista seria apenas um sonho - eterna gratidão; Prof. Dr. Gerlando Augusto Sampaio Franco de Lima: personificação da generosidade e inteligência - apoio constante e amizade imensurável; Prof. Dr. Valdir Heitor Barzzoto: humanidade, sapiência, "visão além do alcance" - grande domínio dos conhecimentos linguísticos. Prof ${ }^{a} \mathrm{Dr}^{\mathrm{a}}$ Márcia Martins Mendes de Luca e Prof. Dr. Romualdo Douglas Colauto pelas preciosas contribuições.

Aqueles que deram parte de seu tempo para o projeto DINTER USP/UEFS e que, com competência e corresponsabilidade, me fizeram acreditar e vencer: $\operatorname{Prof}^{\mathrm{a}}$. $\mathrm{Dr}^{\mathrm{a}}$. Marluce Assis, Prof ${ }^{a}$ Ms.Tânia Cristina Azevedo, Prof. Dr. Rosemberg Valverde, Prof. Dr. Rossini Cruz, Prof. Dr. Nelson Carvalho, Prof. Dr. Bruno Salotti, Prof. Dr. Luiz Fávero, Prof. Dr Andson Braga, Prof. Dr. Lucas Ayres, Prof. Dr. Oliveiros Ferreira, Prof ${ }^{a}$ Dra $^{a}$. Sílvia Casa Nova e Prof. Dr. Luís Afonso. As competentes, proativas e atenciosas funcionárias Márcia Bento (USP) e Vilânia Maria Santana da Silva (UEFS) e o funcionário amigo-irmão Rodolfo Ferrari (USP). 
Os que nos acolheram e nos fizeram sentir o calor baiano no coração de São Paulo: Evandro Ferreira, Belinda Ludovico, Juliana Rodrigues, Róbson Alves e D. Maria e sua equipe.

Colegas do DINTER que me remetem a nobres sentimentos de vitória e superação: Sandra Maria Matos, Róbson Braga, Edmilson Patrocínio, Raimundo Nonato e Emílio Maltez. Em especial, pela presença constante de José Renato Sena Oliveira: generosidade, acolhimento, atenção e cumplicidade; Márcia D’Souza: conselho, cuidado e fé; Ana Santos: companheirismo, amizade e força.

Colegas que partilharam conhecimentos com generosidade e carinho Juliana Amaral, Cíntia Nascimento e as "donas” do meu Abstract: Verônica Santana e Samantha Telles.

Josué Braga que dedicou seu tempo para a materialização do nosso sonho. Ana Meire Santos: amizade e fé. Bruna Camargo e Eduardo Nascimento: os mineiros da minha vida, as aulas não seriam as mesmas sem vocês, amo. Dieng Mamadou: conselheiro-amigo para toda uma vida; Daniel Pereira: pelas orações constantes, carinho e amizade.

Amigos de laboratório, de congresso e companheiros de bandejão Bianca Checon, Cristiane Tiemi, Ludmila Melo, Marília Nascimento, Allan Góis e Raquel Sarquis.

Pesquisadores que participaram com atenção e generosidade do processo de entrevista desta tese e funcionários da Revista Contabilidade e Finanças, na pessoa do Prof. Dr. Fábio Frezatti.

Minha eterna gratidão a Deus por me oportunizar cada um de vocês! 
"O Senhor é meu Pastor, nada me faltará."

(Salmo 23, 1) 


\section{RESUMO}

Aragão, I. R. B. N. (2016). Hegemonia do discurso científico contábil no Brasil. Tese de Doutorado, Faculdade de Economia, Administração e Contabilidade, Universidade de São Paulo, São Paulo.

O objetivo que perseguimos nesta pesquisa foi conhecer especificidades do discurso subjacente às publicações da área contábil a fim de verificar como elas contribuem para o que poderíamos chamar de cultura escrita da área. Secundariamente, buscamos conhecer as identidades/ideologias que emergem da política editorial do contexto da investigação, Revista Contabilidade e Finanças (RC\&F), bem como as decorrentes de instituições e fontes de pesquisa representadas pela visão de mundo dos pesquisadores que exercem influência intelectual sobre a concepção de ciência traduzida por esse periódico. A investigação se fundamentou na visão tridimensional de discurso que emerge da Análise do Discurso (AD) de tradição anglo-saxônica de Fairclough (2008) - texto, prática discursiva e prática social. Essa AD considera o discurso como construção histórica e social, apropriando-se de conhecimentos da linguística para evidenciar, no caso específico desta investigação, marcas textuais impactantes na concepção hegemônica de ciência na área contábil. $O$ corpus examinado foi selecionado dos 355 artigos publicados nos últimos 15 anos da RC\&F online: inicialmente, identificamos a linha de pesquisa hegemônica (Linha 2 - Contabilidade para usuários externos), em seguida, identificamos agrupamentos em função da Abordagem Temática (AT) para determinar proximidade ideológica dos textos, sem perder o foco na atualidade do discurso produzido. Os resultados revelaram que o discurso emergente dos artigos possui léxico técnico, fundamentado na área Contábil e afins, Administração e Economia, além da Matemática, Estatística e do Direito. Há prevalência de termos com polaridade semântica positiva, estrangeirismos e fragilidade no emprego de alguns argumentos de coesão textual. Como interessa-nos o contínuo aperfeiçoamento dos discursos científicos para fortalecimento da cultura escrita da área, focamos os operadores de argumentação para identificar elementos hegemônicos na tessitura desse discurso. Detectamos superficialidade crítica e reflexiva, uso inapropriado de operadores argumentativos e apoio contínuo em intertextos que acabam homogeneizar o discurso analisado. Há prevalência de ideologia normativa e técnica, pouco ou nada interdisciplinar, com tímida potencialidade de provocar inquietações ou trazer efetivas contribuições à cultura escrita da área. $\mathrm{O}$ texto com prática discursiva e social acaba por gerar uma hegemonia fundada no silenciamento dos pesquisadores, e conseguinte reprodução e pactuação com o óbvio, distanciamento de teorias e fuga da criticidade e da realidade social circundante. Tal fato é ratificado pela opinião estabelecida por pesquisadores experientes da área, os quais consideram o discurso científico contábil como: desestruturado, acrítico, intuitivo, imaturo, moldado e descomprometido com a realidade social.

Palavras-chave: Contabilidade - Pesquisa. Discurso científico. Hegemonia. Argumentação. 


\begin{abstract}
Aragão, I. R. B. N. (2016). Hegemony of the Accounting scientific discourse in Brazil. Doctoral Dissertation, School of Economics, Business and Accounting, University of São Paulo, São Paulo.

The objective we seek in this research is knowing discourse specificities underlying Accounting scientific publications in order to verify how they contribute to what we may call the area's strict culture. We also sought to identify the identities/ideologies that arise from editorial policies of the journal Revista de Contabilidade \& Finanças (RC\&F), as well as the ones emerging from institutions and research sources represented by the researchers' view of the world, who exercise intellectual influence on the conception of science translated by this journal. The investigation was based on the discourse's three-dimensional view that arises from the Anglo-Saxon tradition of Fairclough's (2008) Discourse Analysis (DA) - text, discursive practice and social practice. The DA considers the discourse as a social and historical construction which appropriates the linguistic knowledge to highlight, in the specific case of this research, the textual marks that impact the hegemonic conception of science in the Accounting field. The examined corpus was selected from the 355 papers published in the last 15 years in the online version of RC\&F: we first identified the hegemonic area of research (Area 2 - Accounting for external users) and, then, we identified groups formed according to the Thematic Approach (TA) in order to determine the texts' ideological proximity, without losing focus on the discourse timeliness. The results show that the discourse arising from the papers has technical lexicon from Accounting and similar areas, Business and Economics, besides Mathematics, Statistics and Law. Expressions with positive semantic polarity, foreign expressions, and lack of textual cohesion while employing some arguments are prevalent. As we are interested in the continuous improvement of scientific discourse to strengthen this area's writing culture, we focus the argument operators to identify hegemonic elements in discourse construction. We detect critical and reflexive superficiality, inappropriate use of argumentative operators and ongoing support in inter-texts that end up homogenizing analyzed discourse. There is prevalence of normative and technical ideology, with little or none interdisciplinarity and timid potential to cause concerns or to bring effective contributions to the written culture of the area. The text with discursive and social practice ends up generating a hegemony founded on researchers silencing, and, latter, reproduction and agreement with the obvious, detachment to theories, and avoidance of the criticality and the surrounding social reality. This fact is ratified by the opinion established by experienced researchers in the field, which consider the accounting scientific discourse as unstructured, uncritical, intuitive, immature, molded and unengaged with social reality.
\end{abstract}

Keywords: Accounting - Research. Scientific discourse. Hegemony. Argumentation. 


\section{LISTA DE ILUSTRAÇÕES}

Figura 1.Concepção tridimensional do discurso em Fairclough (2008).

Figura 2. Categorias de análise do discurso como texto, visão tridimensional de Fairclough (2008).

Figura 3. Operadores argumentativos das relações pragmáticas em coesões sequenciais frásticas, conforme Koch (2010).

Figura 4. Estabelecimento da concepção hegemônica em Laclau e Mouffe (1987).

Figura 5. Composição do Conselho Editorial de um periódico científico conforme Anpad...66

Figura 6. Entidades representadas pelo Conselho Editorial de um periódico segundo Trzesniak.

Figura 7. Equipe Editorial da RC\&F/2015: pesquisadores, suas funções e país da IES de vínculo.

Figura 8. Entidades representadas na RC\&F por meio do Editor-chefe e dos Editores Associados.

Figura 9. Formação no nível de graduação dos Consultores Ad Hoc da RC\&F.

Figura 10. Maior nível de formação dos Consultores Ad Hoc (avaliadores) da RC\&F e IES onde o curso foi concluído.

Figura 11. Distribuição dos artigos publicados pela Revista Contabilidade e Finanças (RC\&F) por linha de pesquisa nos últimos 15 anos.

Figura 12. Comportamento da distribuição dos artigos publicados na Revista Contabilidade e Finanças (RC\&F) por linha de pesquisa entre 2001 e 2015.

Figura 13. Abordagens Temáticas (ATs) dos artigos publicados na Linha 2 "Contabilidade para usuários externos" - Revista Contabilidade \& Finanças (RC\&F) de 2001 a 2015.

Figura 14. Agrupamentos dos artigos da RC\&F da linha "Contabilidade para usuários externos" por abordagem temática (2001-2015).

Figura 15. Composição do artigo 25.66.2 a partir da análise dos operadores argumentativos de Koch (2010).

Figura 16. Composição do artigo 26.67.4 a partir da análise dos operadores argumentativos de Koch (2010).

Figura 17. Comparação das relações argumentativas nos artigos analisados.

Figura 18. Nuvem com as 50 palavras mais frequentes do artigo 25.66.2. 
Figura 19. Imagens exibidas para detalhar informações metodológicas e de resultados no artigo 25.66.2 da RC\&F.

Figura 20. Nuvem com as 50 palavras mais frequentes do artigo 26.67.4.

Figura 21. Nuvem com as 50 palavras mais frequentes nos artigos da "Contabilidade para usuários externos" publicados entre $2001-2015$.

Figura 22. Imagens exibidas para detalhar informações sobre os resultados do no artigo 26.67.4 da RC\&F.

Figura 23. Características do discurso de textos científicos publicados no formato de artigos em periódicos contábeis.

Figura 24. Característica do discurso científico contábil em artigos de periódicos da área e fatores que contribuem para essa característica....

Figura 25. Característica do discurso científico contábil em artigos de periódicos da área e fatores que contribuem para essa característica. 


\section{LISTA DE TABELAS}

Tabela 1: Dimensões da análise do discurso em Fairclough 38

Tabela 2: Condições para o estabelecimento da hegemonia em Laclau e Mouffe...... 60

Tabela 3: Missão, objetivos e composição da equipe editorial da $R C \& F$ 72

Tabela 4: Escopo e linhas de pesquisa da $R C \& F$. .75

Tabela 5: Informações sobre as referências mais citadas nos seis últimos anos de publicação da $R C \& F$.

Tabela 6: Distribuição das fontes por país e idioma 87

Tabela 7: Tipo e origem do material referenciado 88

Tabela 8: Nome da instituição ou periódico científico que está entre as 20 mais referenciadas $n a R C \& F$ de 2010 a 2015

Tabela 9: Objetivos dos artigos publicados pela $R C \& F$ agrupados na AT1.1 97

Tabela 10: Operadores para estruturação de textos nas relações discursivas, conforme Koch (2010) 104

Tabela 11: Estrutura frástica dos parágrafos dos artigos 25.66 .2 e 26.67.4 da $R C \& F$. 105

Tabela 12: Ocorrências de operadores argumentativos de contrajunção por artigo..... 110

Tabela 13: Ocorrências de operadores argumentativos de conjunção por artigo 116

Tabela 14: Ocorrências de operadores argumentativos de conclusão por artigo 119

Tabela 15: Ocorrências de operadores argumentativos de explicação/justificativa por artigo

Tabela 16: Ocorrências de operadores argumentativos de especificação/exemplificação por artigo

Tabela 17: Ocorrências de operadores argumentativos de comparação por artigo

Tabela 18: Ocorrências de operadores argumentativos de comprovação por artigo

Tabela 19: Ocorrências de operadores argumentativos de contraste por artigo .....

Tabela 20: Ocorrências de operadores argumentativos de generalização por artigo.

Tabela 21: Ocorrência dos operadores argumentativos no corpus examinado.

Tabela 22: Palavras com polaridade positiva encontradas no artigo 25.66 .2 da $R C \& F \ldots . .134$

Tabela 23: Palavras com polaridade negativa artigo $25.66 .2 \mathrm{da} R C \& F$ 
Tabela 24: Palavras com polaridade positiva artigo $26.67 .4 \mathrm{da} R C \& F$

Tabela 25: Palavras com polaridade negativa artigo $26.67 .4 \mathrm{da} R C \& F$.....

Tabela 26: Palavras mais frequentes do artigo 25.66.2 da revista $R C \& F$.

Tabela 27: Classificação das palavras mais frequentes no artigo 25.66.2 de acordo com campo léxico.

Tabela 28: Palavras mais frequentes do artigo 26.67.4 da revista $R C \& F$.

Tabela 29: Classificação das palavras mais frequentes no artigo 26.67.4 de acordo com campo léxico 


\section{LISTA DE ABREVIATURAS E SIGLAS}

AAA

ABNT

$\mathrm{AD}$

$\mathrm{ADC}$

ANEFAC

ANPAD

ASD

AT

Bacen

$\mathrm{BC}$

BM\&FBOVESPA

$\mathrm{BP}$

CAPES

CFC

$\mathrm{CNPq}$

$\mathrm{CPC}$

CTC/ES

CVM

$\mathrm{CV}$

DFC

DRE

DVA

EAA

$\mathrm{EMH}$

EUA

EVG\&D

FEA

FIPECAFI

GRI

IAA

IAAER
American Accounting Association

Associação Brasileira de Normas Técnicas

Análise do Discurso

Análise do Discurso Crítica

Associação Nacional dos Executivos de Finanças, Administração e Contabilidade

Associação Nacional de Pós-Graduação e Pesquisa em Administração

Análise Sociológica do Discurso

Abordagem Temática

Banco Central do Brasil

Banco Central do Brasil

Bolsa de Valores, Mercadorias e Futuros de São Paulo

Balanço Patrimonial

Coordenação de Aperfeiçoamento de Pessoal de Nível Superior

Conselho Federal de Contabilidade

Conselho Nacional de Desenvolvimento Científico e Tecnológico

Comitê de Pronunciamentos Contábeis

Conselho Técnico-Científico da Educação Superior

Comissão de Valores Mobiliários

Currículos Vitae

Demonstração do Fluxo de Caixa

Demonstração do Resultado do Exercício

Demonstração do Valor Adicionado

European Accounting Association

Hipótese dos Mercados Eficientes

Estados Unidos da América

Valor Econômico Gerado e Distribuído

Faculdade de Economia, Administração e Contabilidade

Fundação Instituto de Pesquisas Contábeis, Atuariais e Financeiras

Global Reporting Initiative

International Actuarial Association

International Association for Accounting Education and Research 
IASB

IBRACON

IES

IFES

IFRS

LLPA

LPA

PE

PIB

PLPA

PPGCC

PUC/MG

PUC/SP

$\mathrm{RC} \& \mathrm{~F}$

RCPA

Redalyc

SBFin

SciELO

SIBi

SIBI

SPELL

TCC

TCLE

UCSAL

UFBA

UFCE

UFSC

UnB

USP
International Accounting Standards Board

Instituto dos Auditores Independentes do Brasil

Instituições de Ensino Superior

Instituições Federais de Ensino Superior

International Financial Reporting Standards

Lucro Líquido por Ação

Lucro por Ação

Pesquisadores Entrevistados

Produto Interno Bruto

Patrimônio Líquido por Ação

Programa de Pós-Graduação em Controladoria e Contabilidade

Pontifícia Universidade Católica de Minas Gerais

Pontifícia Universidade Católica de São Paulo

Revista Contabilidade e Finanças

Riqueza Criada por Ação

Revistas Científicas de América Latina, el Caribe, España y Portugal

Sociedade Brasileira de Finanças

Scientific Electronic Library Online

Sistema Integrado de Bibliotecas

Sistema Universitário de Bibliotecas

Scientific Periodicals Electronic Library

Trabalhos de Conclusão de Curso

Termo de Consentimento Livre e Esclarecido

Universidade Católica de Salvador

Universidade Federal da Bahia

Universidade Federal do Ceará

Universidade Federal de Santa Catarina

Universidade de Brasília

Universidade de São Paulo 


\section{SUMÁRIO}

1 HISTÓRIA DA INVESTIGAÇÃO: MOTIVAÇÕES, PROPÓSITOS E CONTRIBUIÇÕES

2 TEORIA DO DISCURSO E TEORIA HEGEMÔNICA: CONCEPÇÕES E CAMINHOS DA INVESTIGAÇÃO .........................................................................

2.1 Concepção de discurso e formação discursiva .................................................31

2.2 Análise do discurso de tradição anglo-saxônica .....................................................35

2.3 A prática da análise do discurso de acordo com Norman Fairclough ................37

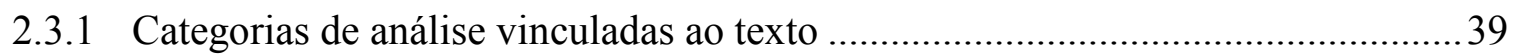

2.3.2 Processo de análise textual: significado das palavras e coesão ............................. 40

2.3.3 Categorias de análise vinculadas à prática discursiva .........................................43

2.3.4 Categorias de análise vinculadas à prática social ............................................... 43

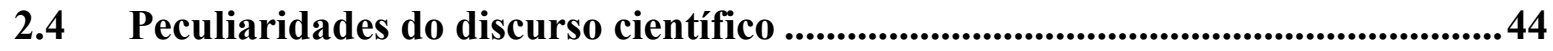

2.5 A pesquisa científica como produção ideológica ...................................................47

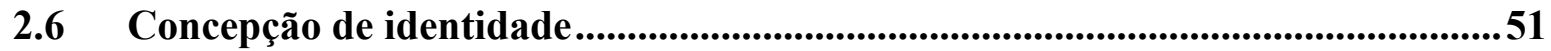

2.7 Sobre a opção da teoria hegemônica de Laclau e Mouffe .......................................54

2.8 Hegemonia em Ernesto Laclau e Chantal Mouffe...................................................57

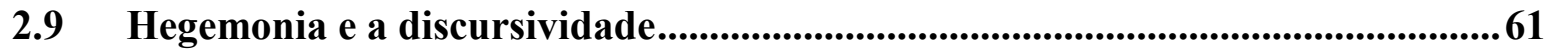

2.10 Práticas que organizam a divulgação do conhecimento ........................................62

2.11 A equipe editorial de um periódico ..................................................................65

3 CONTEXTO DA INVESTIGAÇÃO: REVISTA CONTABILIDADE E FINANÇAS

3.1 Regras editoriais: Revista Contabilidade \& Finanças..........................................71

3.2 Equipe Editorial da Revista Contabilidade \& Finanças .....................................77

3.3 Fontes referenciais da RC\&F nos últimos seis anos .........................................84

3.4 Seleção do corpus: foco na hegemonia das linhas de pesquisa da RC\&F ..........90

3.5 O discurso científico em artigos da área contábil: seleção dos entrevistados ....98

4 A ANÁLISE DO DISCURSO CIENTÍFICO CONTÁBIL ........................................101

4.1 Exame do corpus: $\operatorname{artigos} 25.66 .2$ e 26.67.4

4.2 Análise da coesão textual por meio das relações argumentativas ......................104

4.3 Efeitos ideológicos da prática discursiva: a intertextualidade manifesta .......... 144

4.4 Discurso contábil nos artigos: perspectiva de pesquisadores ............................149 


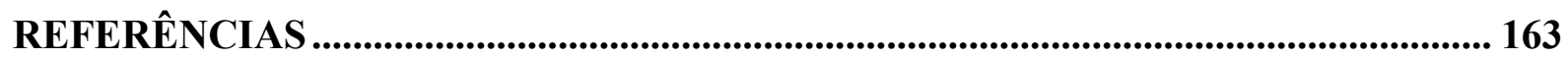

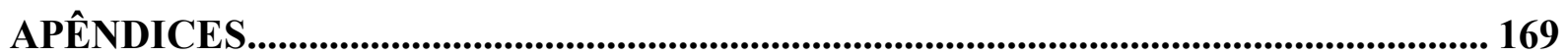

Apêndice A: E-mail encaminhado à Comissão de Pesquisa da FEA/USP .................. 169

Apêndice B: E-mail convite para a participação na investigação.................................. 170

Apêndice C: E-mail para validação da transcrição da entrevista ................................ 171

Apêndice D: Termo de consentimento livre e esclarecido .............................................. 172

Apêndice E: Parágrafos selecionados para análise no artigo 25.66.2 ........................... 173

Apêndice F: Parágrafos selecionados para análise no artigo 26.67.4 ........................ 177 


\section{HISTÓRIA DA INVESTIGAÇÃO: MOTIVAÇÕES, PROPÓSITOS E CONTRIBUIÇÕES}

Recorrendo à memória, entre as motivações que encontro para propor que o discurso latente na pesquisa contábil seja objeto de investigação está a minha experiência em ministrar componentes curriculares vinculados à elaboração de projetos de pesquisa na área contábil. Percebi que parte das propostas apresentadas pelos estudantes se propunha a replicar estudos realizados em grandes centros de pesquisas. As fontes de inspiração, mais frequentes, eram as investigações publicadas nos anais do Congresso de Controladoria e Contabilidade da Universidade de São Paulo ou a Revista de Contabilidade e Finanças [RC\&F], ambos da Faculdade de Economia, Administração e Contabilidade da Universidade de São Paulo (FEA/USP).

Sem perder de vista a relevância da FEA/USP como centro de referência, no contexto nacional e internacional, e a sua tradição em pesquisa na área contábil, uma vez que possui o mais antigo programa de Pós-Graduação em Contabilidade do Brasil (FEA/USP, 2015), o fato mencionado anteriormente suscitou algumas considerações. Se há satisfação em perceber que os estudantes buscam replicar experiências científicas de um centro de referida importância, nos parece interesse pensar sobre o fato de que esses estudantes não demonstravam compreender a importância de tornar a sua universidade em um centro de excelência também. Do mesmo modo, é digno de nota que, ao replicar tais experiências científicas, abre-se mão de tomar para estudo questões próprias da prática contábil da região em que se vive. Entendemos que a pesquisa científica é atividade cultural de uma nação no que diz respeito à construção de novos conhecimentos, mas também expressa atividade prática, vinculada à busca de novas tecnologias, capaz de trazer resultados sociais e econômicos significativos para o país, considerando suas especificações regionais. Embora replicações tenham sua importância, é preciso ter em conta que elas podem refrear a capacidade crítica e a percepção do entorno.

Estas reflexões nos moveram a buscar um caminho para a nossa tese que levasse em consideração que uma pesquisa precisa ter utilidade para o mercado e para a sociedade em geral, efetivando a interação entre academia, prática social e desenvolvimento tecnológico. Entendemos como "produções oportunistas" aquelas que se vinculam a fins que sobrepõem os objetivos sociais e acadêmicos da investigação, pois fragilizam a capacidade de inovação e a dimensão das análises e de contribuição para o desenvolvimento da área contábil, além de paralelamente limitarem a chance de discussões criativas sobre problemas reais e urgentes.

Como a Contabilidade é uma Ciência Social, e tendo em vista as peculiaridades 
socioeconômicas, culturais e políticas do Brasil, é imperativo e coerente que os pesquisadores da área contábil elaborem estudos sobre temas de interesse do nosso país, ou seja, histórica e socialmente circunstanciados, e que direta ou indiretamente podem ser significativos a outros países. Coadunamos com Morin (2005) ao afirmar que a ciência é intrínseca ao seu contexto social e histórico e com Minayo (2002, p. 17) quando a diz que “... nada pode ser intelectualmente um problema, se não tiver sido, em primeiro lugar, um problema da vida prática". Nossa preocupação sobre a relação entre a produção do conhecimento, sua utilidade social e o poder transformador que exerce sobre a qualidade de vida, bem como, sobre o desenvolvimento tecnológico e social de uma nação já estava manifesta em Aragão, Martins, \& Casa Nova (2012).

Nesta linha de reflexão, entendemos que a ruptura da relação entre a ciência e a sociedade desfigura o sentido do próprio fazer científico, uma vez que a ciência é o caminho "mais pleno" e, até então, "mais competente" que o homem criou para compreender e explicar a realidade e para encontrar soluções de dilemas emergentes na sociedade contemporânea. Essa ruptura representa precariedade da função social do pesquisador e inutilidade da pesquisa. A percepção da gravidade, bem como, das consequências negativas que os fatos relatados podem gerar, tanto para a cultura escrita da área contábil, quanto para a sociedade que urge pela compreensão/solução de seus dilemas, são para nós elementos que, também, legitimam a relevância do estudo que propomos. Sabemos da responsabilidade científica imanente desta proposta, todavia, o alcance acadêmico e o sentido social agregado à mesma são fundamentos que nos instigam.

Assim, dessa experiência na formação de estudantes nos componentes curriculares vinculados a projetos de pesquisa em Contabilidade, surgiu o propósito de tomar artigos resultantes de pesquisas contábeis, justamente na revista RC\&F. Isso porque entendemos que era relevante buscar as causas das propostas de replicação, não diretamente no aluno, mas na produção da área como objeto de estudo na presente tese de doutorado. Acreditamos que uma análise desses artigos pode evidenciar aspectos significativos para reflexões de um modo de fazer que hipotetizamos, poderia se disseminar na cultura da própria área. Ou seja, há nesta tese uma oportunidade de explorar o discurso dos artigos científicos por meio de uma perspectiva teórica não oriunda das áreas afins geralmente exploradas, como a Administração e/ou a Economia, mas da Sociologia e da Linguística.

A motivação para a escrita desta tese, portanto, origina-se de um conjunto de propostas de pesquisas e Trabalhos de Conclusão de Conclusão de Curso (TCCs) e que tinham seu contexto de produção marcado por dois elementos fundamentais: a área de 
contabilidade e a origem geográfica em que estavam. Estes dois elementos, como já apontamos, estavam presentes de dois silenciamentos: a) embora as propostas fossem de contabilidade a replicação silenciava o próprio estudante, que não apresentava disposição para fazer aparecer seus próprios posicionamentos e b) a região não estava presente. Isso levou a busca do entendimento a respeito do que segue: o discurso sofre influência do contexto social e, ao mesmo tempo, o contexto social é influenciado pelo discurso, já que o discurso capta, modifica e propõe realidade. Queremos dizer com isso que relatos, descrições e replicações de experiências são formas de captar o que há de concreto em algum lugar. Essas ações linguísticas inserem novos elementos na realidade captada e, ao serem divulgados, em parte indicam que a realidade coincide com o que está em seu interior.

Por isso é importante reconhecer que nos discursos, entre eles o científico, as convicções construídas ao longo do tempo por um sujeito encontram-se marcadas. Por meio das ideias professadas pode-se verificar a identidade do pesquisador que guarda estreita relação com sua produção científica. Ademais, a compreensão do discurso passa pela compreensão de suas condições de produção (Pêcheux, 1990) ${ }^{1}$, ou seja, as circunstancias que levaram a sua elaboração e a conjuntura histórica no qual foi gerado. O discurso científico, como todos os outros, é construído social e historicamente, que o sentido se consolida ancorado em textos, por meio das ideologias expressas nos enunciados que compõem sua tessitura (Coracini, 1991) ${ }^{2}$.

Dessa maneira, estabelecemos como propósito dessa tese conhecer algumas das especificidades do discurso subjacente às publicações da área contábil a fim de verificar como elas contribuem para o que poderíamos chamar de hegemônico na cultura científica escrita da área.

O discurso científico textualizado é, para nós, ambiente de confluência de ações cognitivas, sociais e linguísticas, ambiente onde os sujeitos sociais se manifestam e se interrelacionam, uma tipificação que busca atender às necessidades do público a que se destina. Essa noção de discurso encontra apoio em autores de diferentes perspectivas teóricas. Bakhtin (2003) afirma que o discurso de um indivíduo é marcado por elementos linguísticos, históricos e sociais, cuja manifestação se dá por meio do dialogismo (presença de polifonia nos textos). Foucault $(1996)^{3}$, ao considerar que o sentido do discurso não se encontra nas

\footnotetext{
${ }^{1}$ A noção de condições de produção está desenvolvida na obra Por uma análise automática do discurso: uma introdução à obra de Michel Pêcheux Análise automática do discurso.

${ }^{2}$ Remetemos a obra da autora por ela ter desenvolvido longa pesquisa sobre a suposta neutralidade das chamadas ciências duras.

${ }^{3}$ Discussão propiciada no Arqueologia do Saber.
} 
palavras professadas, mas nas suas formações discursivas e ideológicas que constituem a sua identidade. Logo, assumimos que o discurso que se apresenta nos textos científicos, e todas as escolhas para o proceder sistematizado do método da pesquisa estão impregnados de identidades - nesta tese interessa-nos o discurso de artigos científicos.

Essa discussão pode trazer atenção para a cultura escrita do campo da Contabilidade. Embora nessa cultura escrita ofereça objetos de investigação tais como regulamentos, normas técnicas, relatórios, correspondências oficiais e particulares a respeito de temas ao fazer cotidiano dos contabilistas e seus contratantes, escolhemos para nossa análise os textos acadêmicos. Os achados decorrentes têm potencial para instigar pesquisadores e estudiosos da área a uma reflexão acerca do próprio fazer laboral e científico manifesto pela escrita. Os documentos escritos da área podem definir e direcionar a visão de mundo, impedindo que sejam concebidas discussões ousadas em matéria de discurso científico. Pensamos no quanto será frutífero perceber inquietações intelectuais que se traduzam em questionamentos, autocríticas e/ou reconstrução de entendimento sobre o papel social e os interesses do cientista contábil, bem como sobre os fundamentos que os têm movido para materializar e disseminar os resultados de suas investigações.

Quando elaboramos o projeto inicial para apresentar a proposta desta tese, fizemos uma varredura sobre os conhecimentos produzidos por pesquisadores que nos precederam no estudo da temática "pesquisa contábil”. Nesta varredura, encontramos trabalhos bibliométricos; outros sobre questões metodológicas, e outros de cunho epistemológico. Os trabalhos bibliométricos desenvolvidos apresentam características da pesquisa contábil analisada e têm perfil exploratório, demonstram tendências; já os que estudaram aspectos metodológicos, em geral, discutem sobre os procedimentos adotados pelos pesquisadores, bem como sobre técnicas de coleta e de análise de dados; os epistemológicos, por sua vez, destacam a consistência metodológica e cientificidade das pesquisas.

A existência dessas pesquisas apontou para a falta de uma pesquisa como a que estamos fazendo. Por isso, não pretendemos replicar quaisquer desses percursos anteriormente descritos, visto que os consideramos como lacunas preenchidas. No entanto, algumas investigações nos chamaram a atenção e serão citadas por estabelecerem críticas próximas as que movem este estudo: Cardoso, Pereira \& Guerreiro (2004), por exemplo, realizaram pesquisa bibliométrica e apontam que o crescimento quantitativo da participação de trabalhos na área contábil, não foi acompanhado proporcionalmente por aspectos qualitativos dessas publicações; Martins (2008) afirma em seus resultados de pesquisa que as investigações apresentam apreciações de caráter intuitivo, primitivo e impressionista que fragilizam o 
aspecto cientificidade, configurando-se em meros relatos históricos. Compreendemos que em ambas as análises há evidencias da precariedade tanto no que se refere ao conteúdo e às contribuições quanto em relação aos aspectos metodológicos, tais fatos contribuem para a elaboração de estudos pseudo-científicos e evidenciam certo grau de imaturidade da pesquisa científica contábil brasileira.

Os resultados das investigações sobre a pesquisa contábil realizadas por Zanchet, Marques \& Martins (2011) e Martins \& Zanchet (2012) também trouxeram elementos significativos que fortalecem nossas convicções acerca da lacuna que procuramos preencher. Os primeiros perceberam que há nas investigações predominância da influência positivista, de abordagens metodológicas homogêneas e de tímido aprofundamento ao manifestar compreensão dos resultados. Já estes últimos assinalam uma postura simplista e ingênua acerca do processo de construção do conhecimento, em outras palavras, há evidências da fragilidade de nossas concepções sobre possibilidades/coerências científicas.

Oliveira (2002, p. 72) fez uma pesquisa sobre o “. . . estado-da-arte dos periódicos brasileiros especializados em contabilidade. Essa pesquisa nos interessa porque, além do fato de enfatizar a importância das investigações que se propõe a analisar os periódicos contábeis, oferece resultados que remetem à regionalização/insularização das pesquisas na área e, nos faz retomar a reflexão sobre o fato de que: os pesquisadores, especialmente os iniciantes, preocupam-se em observar as regras e os interesses de estudo dos grandes centros de pesquisa para tornar possível a publicação de seus artigos. A autora constatou que as publicações analisadas originam-se de regiões onde havia concentração de cursos de pós-graduação em Contabilidade - principalmente aqueles que têm por objetivo a formação de corpo docente e pesquisadores.

As conclusões de Oliveira (2002) são relevantes para a nossa discussão porque, nos levam à reflexão sobre as fragilidades apresentadas (insularização da pesquisa, a elaboração de "produções oportunistas" e preocupação em atender a parâmetros de qualidade internacionais decorrente de países de realidade antagônica, por vezes) também nos fazem perceber o peso da intervenção, nem sempre positiva, do Estado no âmbito da pesquisa. Não se pode negar que, em partes, a inserção da avaliação e incentivo à pesquisa para pesquisadores das Instituições de Ensino Superior (IES) e a atuação da Coordenação de Aperfeiçoamento de Pessoal de Nível Superior (CAPES) é um fator que levou à inclusão da pesquisa na pauta dos departamentos e cursos de pós-graduação, e ao consequente aumento do número de trabalhos publicados em todas as áreas. Se hoje podemos criticar a avaliação praticamente toda centrada em critérios quantitativos, é graças a ela que podemos fazer 
pesquisa como a nossa, que tenta incidir sobre a qualidade do texto, não só no sentido de corresponder às pesquisas em termos formais, e de escolhas temáticas, àquelas realizadas nos grandes centros, mas de pensar também uma identidade acadêmica para nossas pesquisas em função da identidade regional em que é realizada.

Apesar de trazerem à tona fatos graves e preocupantes, as pesquisas citadas anteriormente são para nós oportunidade de indagação e delimitam a temática que exploramos. Notamos ainda que os achados dessas investigações possuem um eixo transversal, um sentido comum que os unem e os tornam complementares entre si: a questionável qualidade em artigos científicos de Contabilidade. Ponderamos que a busca por aceitação, prestígio e poder no ambiente acadêmico podem ser fatores que desvirtuam as publicações científicas da área.

A aceitação quer significar a validação da produção científica, ou seja, indica que o artigo científico foi validado por pares e o conhecimento será difundido à sociedade em geral. O prestígio, por sua vez, representa status diante da comunidade acadêmica, consagração do indivíduo como autor no mundo intelectual nacional e/ou internacional. Já o poder seria atributo inerente ao pesquisador aceito e prestigiado, uma consequência dos atributos anteriores. O poder confere ao pesquisador-autor a autoridade discursiva, pois a autoria do texto torna remota a possibilidade de questionamento acerca do conteúdo abordado, o proceder científico torna-se personagem coadjuvante diante da autoridade do pesquisador. A este respeito, Barzotto (no prelo, p. 103-104) afirma que “o julgamento negativo contra o senso comum tende a não aparecer nos casos em que é enunciado por um autor bem posto em lugar de poder".

Entendemos que para pesquisadores de centros "periféricos", aqueles que não pertencem aos grandes centros de pesquisa, seguir o fluxo das temáticas, das teorias de base, das metodologias e das técnicas de coleta e análise de dados de grandes centros de produção intelectual, a exemplo da FEA/USP, pode significar vantagem competitiva para ser introduzido no corporativo mundo da ciência - oportunidade de se tornar um "igual". No entanto, essa vantagem competitiva acaba por manter os que se colocam na condição de seguidores numa vantagem apenas dentro de sua faixa de competição, pois não eleva esses competidores à condição dos que buscam figurar como ponta na produção de conhecimento.

Como os grandes centros de pesquisa são geralmente pioneiros o pesquisador do centro "periférico" acaba aderindo/replicando a maneira de pensar e conceber o mundo, além de inibição na escrita e do desconhecimento, perpassa no mesmo um sentimento de insegurança e/ou imaturidade cientifica. Concordamos com Barzotto (2011, p. 15) ao afirmar 
que “. . é preciso escrever, dominar a maquinaria da escrita e, além disso, procurar fazer esta escrita significar diferentemente daquela pertencente ao poder. . .”. Outro fator que nos interessa relatar é que os grandes centros de pesquisa são formadores de professorespesquisadores (egressos) que estão diretamente "imprintados" com a concepção de mundo desses, tornando-se por vezes em reprodutores intelectuais dos centros.

Como contribuições consequentes, não menos significativas, temos: a elaboração de uma base com informações primárias e o caminho metodológico percorrido neste estudo, conforme veremos no Capítulo 2. As informações que constituem a base foram condensadas em planilha Excel, extraídas de sites fidedignos - RC\&F (periódico em estudo) e periódicos nela referenciados, Plataforma Lattes (Currículo Lattes), o Google Scholar e SCImago Journal \& Country Rank. Tais informações auxiliam na explanação do contexto e são fonte de continuidade dos estudos que ora iniciamos - ampliação do corpus, análises a partir de outras fontes teóricas, dentre outras possibilidades. O nosso caminho metodológico, é peculiar e incomum, incluso há contribuições significativas de aspectos histórico-sociais discutidos e da Linguística para composição dos aspectos analíticos empregados.

Os achados a partir desta base de dados e evidências nos permitem defender a tese de que as formações discursivas das publicações definitivas da área contábil no Brasil contêm ideologias que inibem materialização de contribuições e inovações decorrentes da investigação na área. $O$ estabelecimento desta tese está atrelado à hipótese de que os discursos que emergem das produções definitivas em Contabilidade, disseminada em formato de artigo, geralmente, não se expõem ao risco de tecer críticas desconcertantes. Neste sentido, os autores de artigos científicos em contabilidade reproduzem vozes e, ao mesmo tempo, silenciam sua capacidade crítica, deixando emergir um discurso que omitem por meio desse silêncio.

Esta tese está dividida em cinco capítulos. Este é o Capítulo 1, onde expusemos as motivações, os propósitos e as contribuições deste estudo, o Capítulo 2 apresenta o marco teórico que fundamenta nossas concepções e caminho metodológico percorrido para consecução dos resultados. No Capítulo 3, apresentamos o contexto da nossa investigação, bem como o processo de seleção do corpus deste estudo e como das etapas percorridas para a realização e análise das entrevistas. No Capítulo 4, temos a análise dos resultados da investigação onde tratamos sobre peculiaridades inerentes ao discurso enunciado em artigos científicos e sobre os efeitos ideológicos desta prática. No Capítulo 5, apresentamos as nossas conclusões. 


\section{TEORIA DO DISCURSO E TEORIA HEGEMÔNICA: CONCEPÇÕES E CAMINHOS DA INVESTIGAÇÃO}

Neste capítulo, apresentamos as concepções e conceitos dos quais nos apropriamos para a realização desta investigação. Trata-se de fundamentação teórica e metodológica, conceitos vinculados à Linguística, mais especificamente à Análise do Discurso e à Teoria Hegemônica de Laclau e Mouffe (1987) que alicerçam o exame do corpus adotado: artigos e entrevistas. Além disso, trouxemos uma discussão sobre as peculiaridades do discurso científico, da sua função como produção ideológica e identitária, bem como sobre a estrutura e a função da equipe editorial no processo de disseminação do conhecimento científico. Em seguida, apresentamos as peculiaridades/regras relacionadas à forma textual com que o discurso científico se apresenta.

A pesquisa que desenvolvemos é fundamentalmente qualitativa uma vez que buscamos compreender, descrever e interpretar os fenômenos estudados. Porém, complementarmente, nos utilizamos de valores relativos para mensuração e emissão de parecer acerca de aspectos relacionados ao corpus examinado, daí o seu caráter quantitativo (Martins \& Theóphilo, 2009). Utilizamos como estratégia o exame de documentos combinados com entrevistas para apreciação e interpretação, fontes primárias, fator que tem potencialidade para minimizar o risco de vieses analíticos. Os documentos examinados foram a Política Editorial da RC\&F, os artigos selecionados e as gravações das entrevistas, conforme veremos a seguir.

Ressalta-se que não temos qualquer intenção inferencial nesta pesquisa, o nosso interesse maior é descrever e analisar com critério e profundidade o contexto e o corpus em estudo de tal forma que possamos compreender e interpretar o discurso emergente dos textos contábeis por meio de um prisma não usual - teoria do discurso e teoria hegemônica.

\subsection{Concepção de discurso e formação discursiva}

Melo (2009) trata sobre as dificuldades do estabelecimento de um sentido e do número de equívocos que se tem cometido quando se faz referência ao termo "discurso" ou à expressão "análise do discurso". Segundo este autor, "a expressão análise de discurso tem suscitado uma série de equívocos em razão da diversidade de significados atribuídos ao termo discurso" (p. 2). Seja nas distintas áreas de conhecimento, seja em cada tradição, ou em cada vertente dentro de uma mesma tradição, o termo "discurso" pode ser adotado com base em 
diferentes conotações em função da conjuntura em que se insere.

Não se pretende aqui explorar todas as possibilidades de entendimento acerca do termo ou denotar qualquer juízo de valor para estas possibilidades, mas apresentar algumas delas a título de ilustração, ratificando a importância da delimitação do seu sentido diante da densidade de interpretações ao reconhecer o seu devido valor para o desenvolvimento da ciência e sua compreensão no contexto em que foram elaboradas.

Os estudos antigos sobre retórica se apropriam do termo discurso para elucidar uma maneira de persuadir, ou seja, o discurso é base estratégica utilizada para convencer por meio da oratória (Barros, 2012; Brandão, 2004). Na concepção linguística o discurso é estático, e a análise decorrente dele enfoca sua estrutura como agregado de frases ou termos. Dubois (2007) aponta três entendimentos distintos para discurso: no primeiro, o discurso é acepção de fala, ou seja, a linguagem em ação; no segundo, tem-se o discurso como uma mensagem sequenciada, um enunciado; e no terceiro, o discurso toma o sentido explorado por Fiorin (1993, p. 80) "toda combinatória de elementos linguísticos provida de sentido". As concepções apresentadas pelo autor evidenciam uma ampliação do conceito à medida que as ideias são expressas, deslocando-se de uma visão de fala para formulações mais amplas e complexas que se combinam na busca de conceber a comunicação. Fiorin (1993) também considera o discurso como estrutura e ressalta a existência intrínseca a ele de uma sintaxe e uma semântica, essa última como seu campo de determinação ideológica. Já em Foucault (1997) o discurso se constitui de "práticas sociais" ou "práticas discursivas", que se condensam em um conjunto de enunciados atrelados a um sentido histórico.

Para Pêcheux (1990), o precursor da análise do discurso de tradição francesa que fundamenta as ideias de algumas das outras escolas da análise do discurso, a exemplo da linha anglo-saxônica, o termo discurso é entendido como substância ideológica.

Carrieri $(2001 ; 2009)$, pesquisador que estuda análise do discurso francesa, considera o discurso como redes de relações nas quais os indivíduos se inserem, exprimindo regras de conduta atreladas e direcionadas por uma ideologia. Percebe-se que, ainda que inseridos em uma mesma abordagem de análise do discurso, o conceito de Pêcheux (1990) é ampliado e contextualizado pela introdução das ideias de "rede de relações" e "regras de conduta" em Carrieri (2001).

Van Dijk (2008), estudioso da análise crítica do discurso francesa, concebe o discurso como maneira de estabelecer o poder no contexto contemporâneo que guarda profunda relação com a cognição e com o social. Ao definir discurso, van Dijk (2008) afirma que ele é uma das importantes condições das 'mentes' que todos os indivíduos em sociedade desfrutam. 
Percebe-se que suas ideias constituem uma base de pensamento focada na cognição, fortemente atreladas à Psicologia Social.

Van Dijk (1990) descreve características contemporâneas da AD, fundadas nas diferentes abordagens que são: transdisciplinaridade, descrição textual e contextual, interesse pela fala da cotidianeidade, interesse pela multiplicidade de gêneros do discurso e abertura da base teórica. Estas características vão ao encontro de aspectos relacionados ao sujeito ou ator social que elabora o discurso, bem como ao contexto em que ele está situado, cuja materialidade se dá por meio das formações discursivas.

Uma segunda definição significativa para a investigação que realizamos é o sentido da expressão "formação discursiva". Orlandi (2009, p. 43), que fundamenta suas ideias em Pêcheux (1995), define formação discursiva (FD) como algo que determina o que deve ser dito em uma determinada formação ideológica. Observa-se que a ideia de formação discursiva é bastante semelhante e vai ao encontro do sentido explorado por Pêcheux (1995), dado que enfatiza a questão da predeterminação ideológica como constituída baseada em tal formação discursiva.

O conceito de formação discursiva está diretamente relacionado com a questão do sujeito linguístico e sócio-histórico. Pêcheux (1995) repensa o conceito de formação discursiva elaborado por Foucault e reconstrói a ideia considerando-a como: "aquilo que, numa conjuntura dada, determinada pelo estado de luta de classes, determina o que pode e deve ser dito", definição marcada pelo viés marxista ao se referir à ideia de luta de classes. Nesse primeiro momento, as formações discursivas se relacionam com as formações ideológicas no contexto de uma realidade social conduzida por uma ideologia dominante. Pode-se afirmar que a formação discursiva (FD) é ambiente teórico no qual se evidencia relação entre Michel Pêcheux e Michel Foucault na elaboração da teoria e análise do discurso, visto que, posteriormente, as ideias desses estudiosos vão se articulando numa crescente perspectiva de heterogeneidade. Guilhaumou (1986) considera que, por ser parte das categorizações básicas, a noção de formação discursiva foi aquela que mais provocou efeitos significativos sobre o processo de metamorfose da análise do discurso ao longo do tempo. Este é, portanto, um dos aspectos que entendemos como fomentadores da pluralidade teóricometodológica da AD.

Althusser, que faz uma releitura da obra de Marx, considera a formação discursiva como uma construção ideológica. Em sua concepção, a ideologia dominante é a da classe dominante. Foucault, por sua vez, não compreende as formações discursivas como ideologia, mas como termo vinculado à ideia de saberes e poderes. Jean Jacques Courtine, estudioso da 
análise do discurso com viés político de tradição francesa, tem papel central no desenvolvimento do sentido de formação discursiva por estimular a interlocução às produções de Pêcheux e de Foucault. Courtine (2009) trata a formação discursiva como elemento fundamental da análise do discurso, uma vez que demonstra os saberes que se estabelecem por meio do interdiscurso - local em que se organizam os objetos de que o enunciador se utiliza para a construção do seu discurso.

Conforme Sargentini e Navarro-Barbosa (2004), a formação discursiva é um conjunto de enunciados que se concatenam a outros enunciados, baseado em regularidades internas, constituindo-se num sistema de autonomia relativa. Essa autonomia e regularidade interna não guardam linearidade e homogeneidade, dado que não definem uma unidade de conceitos imutáveis com relações definidas entre si. Pelo contrário, o quadro é de configurações mutáveis e de conceitos em transformação; assim, a formação discursiva contemporânea deve estar atrelada à dinâmica do contexto histórico-social, aos variados meios tecnológicos de circulação e propagação dos discursos. Esses meios tecnológicos exploram enunciados verbais e não verbais que se sustentam e instauram por meio da comunicação em massa.

Adinolfi (2006, p. 4) considera que "a formação discursiva é o locus onde arbitrariamente são determinados os sentidos de um discurso, o dizível e o indizível, é onde ocorre a produção do sentido de verdade em contraposição aos sentidos inverídicos”. Assim, pode-se dizer que a FD representa a tessitura do discurso hegemônico - uma prática, não perene e heterogênea, atrelada à realidade sócio-histórica, portanto, ideológica e permeada por identidades. É nesse sentido que o corpus discursivo desta tese será analisada.

Nesta tese, adotamos a visão tridimensional de discurso de Fairclough (2008), tradição anglo-saxônica, que o considera como uma materialização ideológica que favorece a criação de identidades. Ou seja, "a forma por meio da qual as pessoas podem agir sobre o mundo e especialmente sobre os outros, como também um modo de representação" (p. 91). Esta concepção de discurso evidencia o poder que ele possui tanto para influenciar quanto para ser influenciado por meio da língua, exprimindo concepções de mundo (ideologias) e valores por meio da formação discursiva - em Fairclough (2008) a formação discursiva indica o que pode e o que deve ser dito baseado em uma posição ideológica, assim ela é uma construção que reflete a maneira pela qual o indivíduo percebe o mundo à sua volta.

As ideias de Fairclough sobre discurso e formação discursiva vão ao encontro do que apregoa Laclau \& Mouffe (1987) em sua teoria hegemônica do discurso, visto que o termo discurso é definido como uma totalidade transitória, não neutra, estruturada, com base na prática articulatória constitutiva da formação discursiva - é esta hegemonia que buscamos 
evidenciar no corpus que tomamos para análise, e confrontar com a concepção dos pesquisadores da área contábil que foram entrevistados.

\subsection{Análise do discurso de tradição anglo-saxônica}

No âmbito da análise crítica do discurso, a linguagem é considerada como uma prática social. Nesse sentido, o contexto torna-se aspecto crucial para estudos inerentes a questões como domínio, controle e poder, relacionadas à questão hegemônica do discurso. Essa é a maneira de conceber a AD com base na tradição anglo-saxônica de Fairclough (1989, 1995, 2003, 2008), a qual será acomodada neste estudo.

Segundo Silva \& Ramalho (2008), a Análise do Discurso Crítica (ADC) foi introduzida no Brasil em 1993, por meio da investigação de Magalhães (2001), realizada na Universidade de Brasília (UnB), fortalecendo-se em 1996 com a publicação do livro "Texts and practices: readings in critical discourse analysis", organizado por Caldas-Coulthard e Coulthard, da Universidade Federal de Santa Catarina (UFSC) e da Birminghan University, respectivamente.

A ADC, desenvolvida por Fairclough (2008), considera o texto, a interação (prática discursiva) e a ação social (prática social) como dimensões do discurso. A atividade crítica a que esse autor se refere consiste na capacidade de fazer emergir a natureza interligada das coisas. Nesta perspectiva, o texto é entendido como linguagem escrita ou falada que contribui para a transformação social, para a composição de identidades e relações sociais, bem como para compor um sistema de conhecimento e de crença (Halliday, 2004).

Nesta abordagem, a prática discursiva se realiza por meio da linguística. Ou seja, refere-se à utilização da linguagem nos procedimentos de elaboração, distribuição e consumo dos textos. Já prática social guarda relação com significado e construção da realidade (ideologia) e relações de dominação (poder). Segundo Fairclough (2008), as formações discursivas mantêm integração com outras formações discursivas por meio da interdiscursividade, afetando os sujeitos de maneira inconsciente e criando uma percepção utópica de que eles são fontes de sentidos. Todavia, esse entendimento de discurso como prática social, além de determinar uma maneira de os indivíduos agirem no mundo e sobre outros indivíduos, é também uma forma de representação social.

Wodak (2010) ressalta que a ADC considera o discurso, situado em tempo e espaço, como uma estrutura construída por meio da dominação institucionalizada por grupos poderosos. Portanto, favorece a análise das pressões e da resistência que emergem em forma 
de convenções sociais. Tanto os discursos gerais quanto aqueles que se originam de disciplinas específicas que possuem enunciados específicos (discursivos e não discursivos), são modelados e alterados por estruturas sociais, as quais influenciam e sofrem influência desse discurso, estabelecendo, assim, uma relação dialética.

Fairclough (2008) se apropria das concepções de poder do discurso e agrega às concepções de ideologia e hegemonia, propiciando a implementação de um salutar avanço interpretativo para esta abordagem de análise, sobretudo no que diz respeito à ideologia.

\begin{abstract}
A investigação do discurso como prática social é feita a partir de um conceito de discurso ao qual se relacionam "ideologia" e "poder". Fairclough (2001:116) situa o discurso numa perspectiva de poder como "hegemonia" e de evolução das relações de poder como luta hegemônica. Para tanto, toma partido dos conceitos de hegemonia e poder conforme apresentados por Gramsci (1971) e de ideologia tomando por base o conceito de Althusser (1971); entretanto, problematiza-o por não dar atenção à resistência, à luta e à transformação. Permeia a proposta teórica faircloughiana a premissa de que as situações opressoras podem ser mudadas, uma vez que são criações sociais e, como tal, passíveis de transformações sociais.(Barros, 2008).
\end{abstract}

Compreendemos que a proposta faircloughiana se aproxima da proposta de hegemonia anunciada por Laclau e Mouffe em função da perspectiva de mutação e não perenidade decorrente das criações sociais propiciadas por meio dos discursos - em Gramsci a hegemonia há certa estabilidade hegemônica em função do poder coercivo do Estado. A instituição da desigualdade e da discriminação são objetos de análise da ADC, uma vez que seus estudiosos entendem que o discurso é meio de estabelecer relações de poder e dominação social. Nesta tese, consideramos que o discurso científico evidenciado nos textos de artigos da área contábil tem o poder de estabelecer uma hegemonia ideológica, reprodutora de uma maneira homogênea e pouco crítica de pensar e fazer ciência.

Ao tratar sobre a utilização da Análise Sociológica do Discurso (ASD) no contexto contemporâneo, Fairclough (2008, p. 272) ressalta que "uma das justificativas para uma abordagem da análise do discurso centrada na intertextualidade e na interdiscursividade, e noções associadas, tais como heterogeneidade e ambivalência do discurso, é que as ordens do discurso contemporâneas são cheias de semelhantes textos híbridos" - fato marcante quando nos referimos a textos científicos da área contábil, como os que nos propusemos a analisar.

A ASD de Fairclough (2008) foi, então, adotada como prática metodológica para essa investigação em virtude de suas concepções convergirem com aquelas inerentes à hegemonia do discurso empreendidas por Laclau \& Mouffe (1987). Em outras palavras, pode-se afirmar que a teoria do discurso hegemônico estabelecida por meio da prática discursiva (Laclau \& Mouffe, 1986) vai ao encontro do discurso como prática social em Fairclough (2008). Parte-se da concepção de que o discurso e o contexto social interagem, dialeticamente, em um 
ambiente contemporâneo complexo e dinâmico, produzindo as identidades e impossibilitando a fixação de um sentido a esse discurso.

O discurso como prática social em Fairclough (2008) contribui sobremaneira para a constituição das identidades. Essas identidades são elementos que podem se manter vinculados à formação discursiva hegemônica por meio da prática articulatória, ou isolados da estrutura discursiva, constituindo o contra-hegemônico (Laclau \& Mouffe, 1987). Além dos aspectos descritos, a ASD oferece dimensões e categorias de análise, verbal e não verbal, algumas das quais foram exploradas para o alcance do objetivo geral desta pesquisa.

\subsection{A prática da análise do discurso de acordo com Norman Fairclough}

A análise do discurso, metodologia qualitativa de cunho interpretativo, se estabelece neste estudo como atividade prática necessária para a consecução do objetivo geral perseguido nesta tese: investigar a formação hegemônica do discurso científico da pesquisa contábil disseminada na forma de artigo.

O desenvolvimento da análise por meio da Teoria Social do Discurso objetiva propiciar interpretações por meio da linguística. Para Fairclough (2008), o discurso é abordado como texto, prática discursiva e como uma prática social, coadunando com a concepção de discurso expressa em Laclau \& Mouffe (1987). Fairclough (2008) concebe como funções significativas da linguagem para a análise do discurso: a função identitária, a função relacional e a função ideacional. A primeira refere-se à maneira pela qual as identidades sociais se manifestam no discurso; a segunda, como as relações sociais entre os partícipes de um grupo são representadas; a terceira, por sua vez, exprime os modos pelos quais os textos denotam o mundo.

A Figura 1 a seguir evidencia a maneira pela qual o discurso é concebido por Fairclough (2008, p. 101). As dimensões evidenciadas na figura representam a percepção desse autor acerca do discurso. Tais dimensões são explicadas por categorias de análise, as quais permitem inferências acerca desse discurso em relação a aspectos da prática social. 


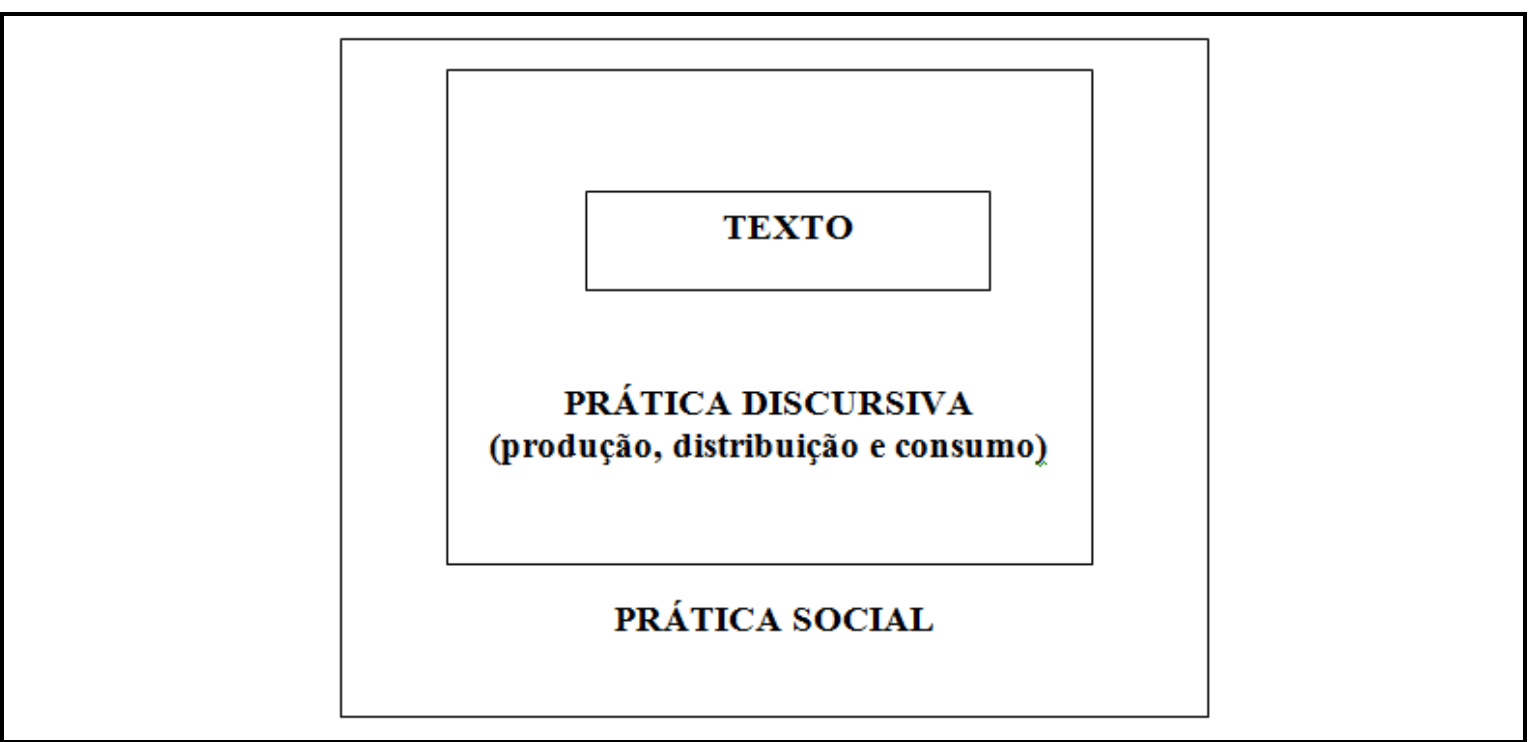

Figura 1.Concepção tridimensional do discurso em Fairclough (2008).

Complementarmente, o autor oferece como proposta de planejamento a preparação de três etapas para concretização da análise do discurso. Porém, ele ressalta que durante o processo de execução do método tais etapas acabam por se sobrepor - não há rigidez na sua execução, pois elas ocorrem de acordo com a intenção do analista. Nesta tese, analisamos inicialmente o discurso enquanto texto, e em seguida, enquanto prática discursiva. Para o primeiro momento consideramos o vocabulário e a coesão realizada por meio de operadores argumentativos. No segundo, analisamos a intertextualidade manifesta para identificação das ideologias que emergem do discurso. A sequência oferecida por Fairclough torna-se uma estratégia auxiliar a esse processo: (1) análise das práticas discursivas; (2) análise de texto; e (3) análise da prática social da qual o discurso faz parte.

Tabela 1:

Dimensões da análise do discurso em Fairclough

\begin{tabular}{ll}
\hline \multicolumn{1}{c}{ (etapas propostas) } & \multicolumn{1}{c}{ Categorias de análise } \\
\hline $1^{\text {a }}$ Prática discursiva & Intertextualidade manifesta; Interdiscursividade; \\
& Cadeias intertextuais, coerência e condições da prática discursiva. \\
& Controle interacional, coesão, polidez, ethos, gramática (transitividade, tema, \\
$2^{\text {a }}$ Texto & modalidade) significado das palavras, criação de palavras e metáforas. \\
& $\begin{array}{l}\text { Matriz social do discurso, ordens do discurso, efeitos ideológicos e políticos } \\
\text { do discurso. }\end{array}$ \\
\hline
\end{tabular}

As categorias apontadas por Fairclough (2008), conforme Tabela 1, se constituem na possibilidade de materializar investigações e apreciações científicas de cunho qualitativo acerca do discurso. Tais investigações integram questões culturais, sociais e políticas relevantes ao contexto contemporâneo por favorecerem o estabelecimento de novos olhares e a compreensão de fenômenos relevantes para o desenvolvimento da ciência e das diversas 
áreas de conhecimento.

\subsubsection{Categorias de análise vinculadas ao texto}

As categorias a serem descritas relacionam-se a aspectos formais do texto. Algumas delas se direcionam aparentemente a formas linguísticas, enquanto outras aparentemente são orientadas para os sentidos. Todavia, Fairclough (2008) argumenta a inutilidade de tal distinção em virtude do fato de que o analista de texto trabalha concomitantemente com a questão de forma e significado.

O processo de apreciação analítica do texto pode ser organizado em quatro elementos: vocabulário, gramática, coesão e estrutura textual (Fairclough, 2008). O primeiro relaciona-se a uma análise individualizada das palavras; o segundo, das palavras estruturadas em orações e frases; o terceiro, da amarração das frases e orações; e o quarto, da questão organizacional numa ampla escala do texto. Segundo Fairclough (2008, p. 104).

Toda oração é multifuncional e, assim, toda oração é uma combinação de significados ideacionais, interpessoais (identitários e relacionais) e textuais ... As pessoas fazem escolhas sobre o modelo e a estrutura de suas orações que resultam em escolhas sobre o significado (e a construção) de identidades sociais, relações sociais e conhecimento e crença.

As categorias de análise textuais são sobremaneira relevantes para esta pesquisa uma vez que denotam sobre as identidades constitutivas dos textos, ou seja, têm a potencialidade de caracterizar uma identidade à medida que refletem relações sociais (grupos a que se pertence), e ainda os conhecimentos e as crenças que constroem com base em tais relações. Nesta tese, analisamos a coesão por meio dos operadores argumentativos, já que é nosso interesse perceber as contribuições/limitações estabelecidas por meio destas argumentações. Tomamos também o significado das palavras para identificar aspectos como a polaridade do léxico e estrangeirismos, bem como analisamos as áreas de conhecimento que estão presentes nos discurso científico da área contábil destas palavras - acreditamos que estes elementos podem nos oferecer pistas sobre as influências culturais refletidas no léxico.

Assim, quando se faz alusão à categoria de significado das palavras, direciona-se a atenção para as palavras-chave no texto, cuja apreciação permite ao analista verificar o significado cultural geral expresso como um modo de foco na hegemonia. Fairclough (2008, p. 230) afiança que “... os significados das palavras e a lexicalização de significado são questões que são variáveis socialmente e socialmente contestadas e facetas de processos sociais e culturais mais amplos". A análise do significado das palavras permite a interpretação 
acerca de aspectos hegemônicos, elemento de interesse desta pesquisa.

A coesão, outra categoria relacionada ao discurso como texto, tem como finalidade "mostrar como as orações e os períodos estão conectados no texto" (Fairclough, 2008, p. 286), auxiliando no processo de reconhecimento da sua retórica - espécie de argumentação utilizada - bem como os modelos de racionalidade por ela pressupostos a fim de identificar as identidades sociais que o permeiam e dão significado cultural, teórico e ideológico, aspectos a serem explorados no contexto da investigação aqui proposta.

\subsubsection{Processo de análise textual: significado das palavras e coesão}

Dentre as categorias de análise vinculadas ao texto em Fairclough (2008), tomamos para exame dos artigos o significado das palavras (léxico) e a coesão argumentativa, conforme representado na Figura 2, a seguir:

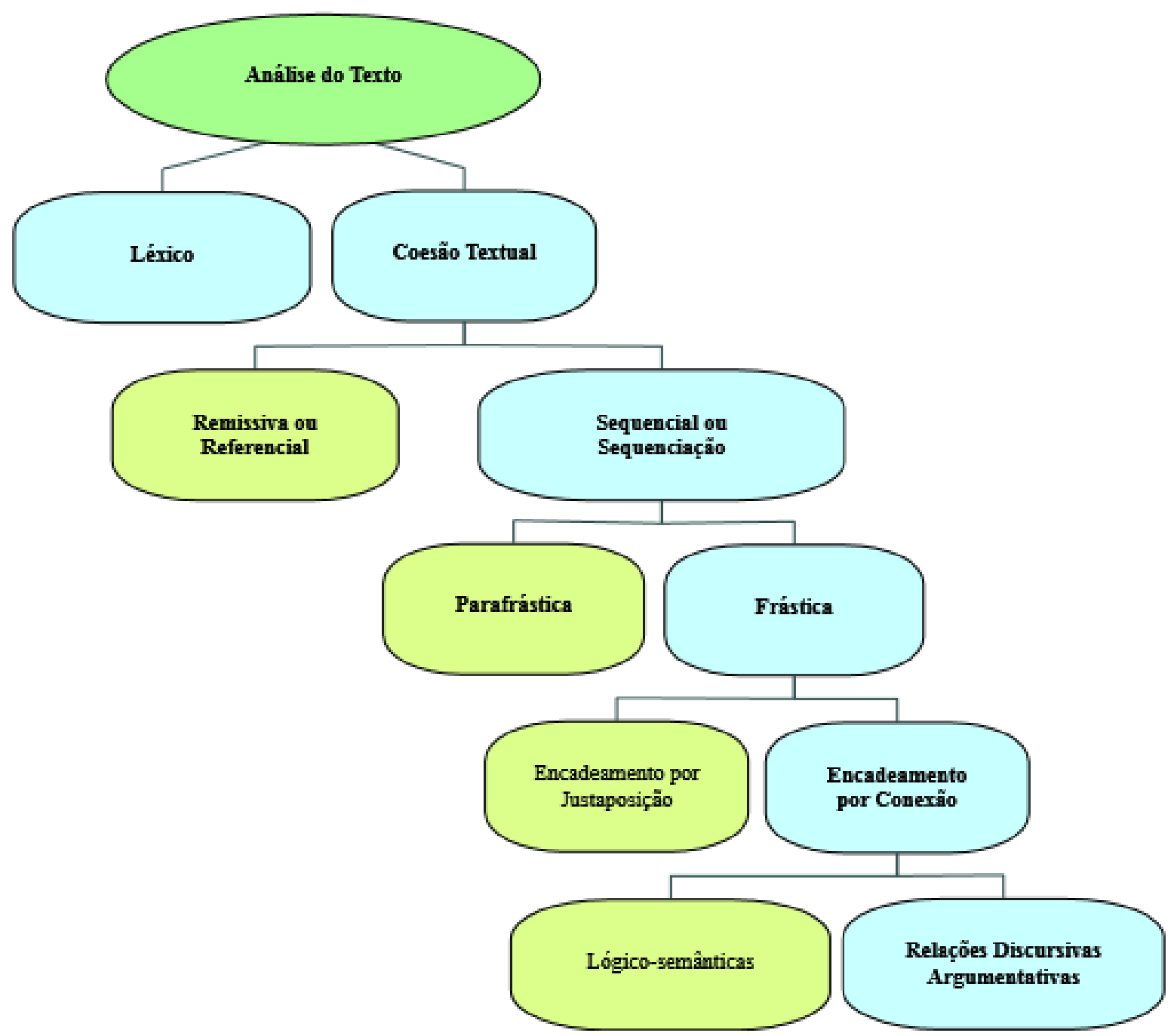

Figura 2. Categorias de análise do discurso como texto, visão tridimensional de Fairclough (2008). 
Para a análise do léxico, os artigos foram exportados para o software NVivo 11; em seguida, realizamos a análise de frequência agrupada por "correspondência exata" as cem palavras mais frequentes com extensão mínima de quatro caracteres. A partir do resumo de frequências obtido, eliminamos as palavras que não guardavam sentido no texto (funcionavam apenas como conectivos). Solicitamos mais uma vez a análise de frequências, desta vez para as cinquenta palavras mais frequentes, agrupada "com palavras derivadas". Em seguida, geramos uma sumarização que exibimos em forma de nuvem de palavras (imagem evidenciada na análise de resultados).

Em função da análise que realizamos com base na sumarização obtida (resumo de frequências), criamos quatro classificações para o léxico: léxico contábil, no léxico político/administrativo; léxico matemático/estatístico; léxico econômico/financeiro e estrangeirismos - as palavras foram segregadas em função dessas classificações, conforme análise de resultados. Verificamos a polaridade semântica das palavras no texto, análise da representação das palavras de polaridade negativa e polaridade positiva. Elaboramos ainda a nuvem de palavras, para representação da frequência e analisamos o jogo de palavras utilizadas no Referencial Teórico dos artigos para delimitar a lacuna explorada, conforme Fairclough (2008), para perceber se há um significado cultural mais geral ou mais local.

Na perspectiva da coesão, verificaremos os "laços" ou "elos" que utilizamos como recurso semântico para conexão do texto, cuja função é oferecer maior legibilidade e estabelecer coerência argumentativa à superfície textual. Trabalhamos especificamente com a coesão textual sequencial frástica que se dá nas relações discursivas ou argumentativas por meio de operadores argumentativos (conectores). Tais operadores argumentativos estabelecem as chamadas relações pragmáticas ou argumentativas, conforme ilustrado na Figura 3. 


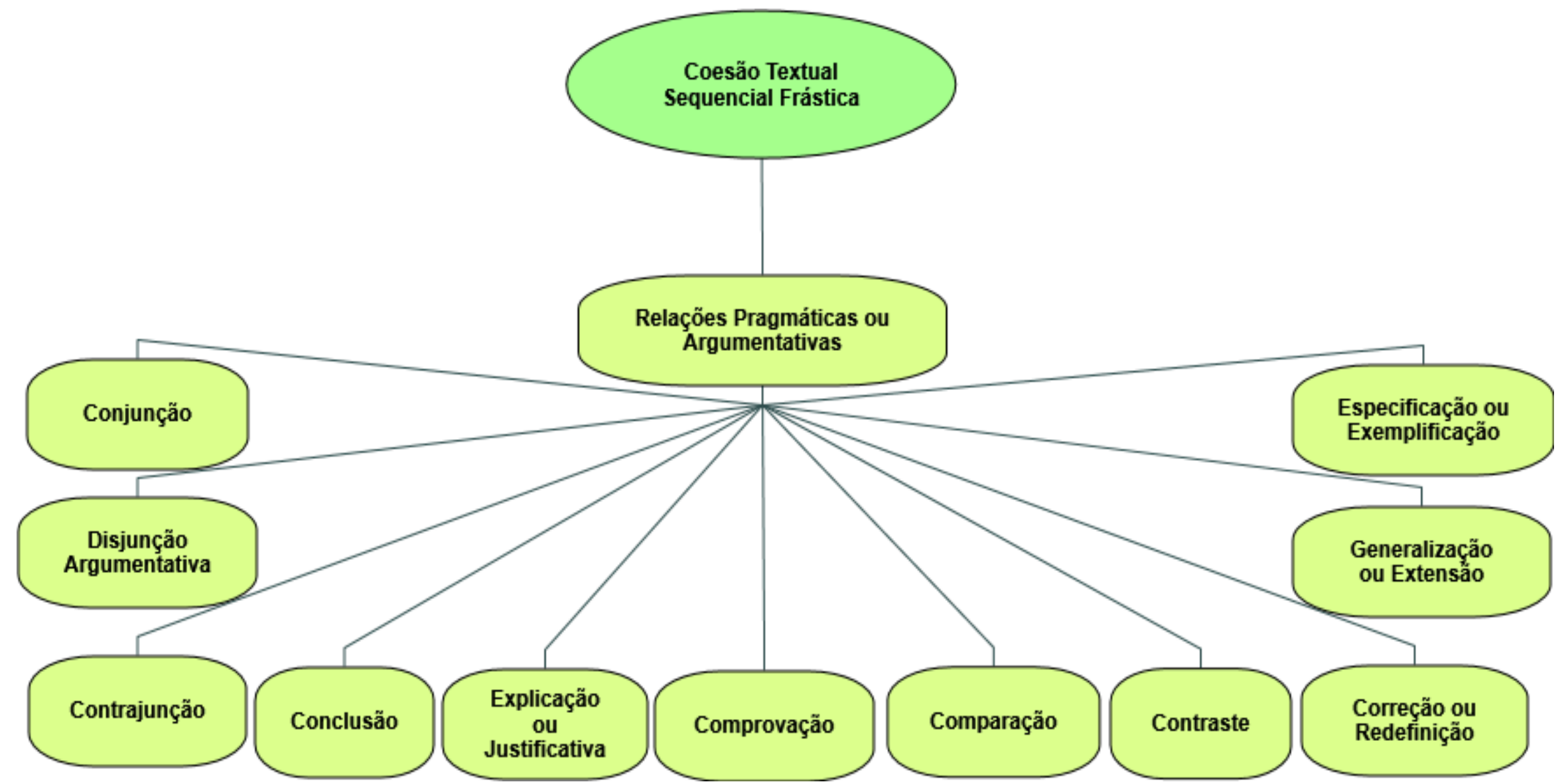

Figura 3. Operadores argumentativos das relações pragmáticas em coesões sequenciais frásticas, conforme Koch (2010). 
A fim de que nosso discurso não se torne repetitivo, as relações evidenciadas anteriormente por meio da Figura 3 serão detalhadas no Capítulo 4, especificamente no tópico 4.2, o qual apresenta a análise corpus.

\subsubsection{Categorias de análise vinculadas à prática discursiva}

As categorias de análise relacionadas à prática discursiva permitem uma leitura do discurso fundamentada em aspectos sociais e contribuem para elaboração de inferências sobre diversas perspectivas desse discurso, incluso a ideológica. Essas categorias são: interdiscursividade, cadeias intertextuais, coerência, condições da prática discursiva e intertextualidade manifesta, nesta tese interessa-nos esta última.

Para Fairclough (2008), a intertextualidade deve ser a principal categoria a ser estudada na análise do discurso contemporânea devido à fugacidade e reestruturação das tradições textuais e ordens de discurso. Essa categoria guarda uma proeminente relação com a hegemonia. Tal intertextualidade se caracteriza pela propriedade que os textos possuem de serem constituídos por fração de outros textos, mesclados ou evidenciados de maneira explícita, estabelecendo com eles relação de ironia, reverência, contradição, assimilação, dentre outras.

A intertextualidade manifesta ocorre quando outros textos são apresentados de maneira explícita no texto sobre análise, e a interdiscursividade (intertextualidade constitutiva) aponta os tipos de discursos demarcados na amostra discursiva em apreciação. Segundo Fairclough (2008, p. 152), "a intertextualidade manifesta é o caso em que se recorre explicitamente a outros textos específicos em um texto, enquanto a interdiscursividade é uma questão de como um tipo de discurso é constituído por meio da combinação de elementos de ordens de discurso". O objetivo de análise da intertextualidade num texto é evidenciar os tipos de discursos presentes na amostra discursiva sobre análise.

\subsubsection{Categorias de análise vinculadas à prática social}

As categorias de análise do discurso relacionadas à prática social não são facilmente reduzidas, tendo em vista a natureza complexa e dinâmica da prática social na qual a prática discursiva se integra. Tais categorias visam mostrar os efeitos da prática discursiva na prática social, a saber: matriz social do discurso, ordens do discurso e efeitos ideológicos e políticos do discurso. Nesta tese ela não será examinada, porque não estamos realizando análise 
longitudinal - o discurso que analisamos está circunstanciado historicamente nos anos de 2014 e 2015; portanto, não cabe a análise de efeitos sociais decorrente dos mesmos. Desta forma, apresentaremos, sucintamente, as categorias relacionadas a essa dimensão do texto.

A matriz social do discurso busca refletir "as relações e estruturas sociais e hegemônicas que constituem a matriz dessa instância particular da prática social e discursiva; como essa instância aparece em relação a essas estruturas e relações" (Fairclough, 2008, p. 289-290). As ordens do discurso buscam clarificar a relação existente entre a prática discursiva e as ordens do discurso, bem como os efeitos de reprodução e transformação de tais ordens. Por fim, os efeitos ideológicos e políticos do discurso visam evidenciar ideologias que permeiam as práticas discursivas, uma vez que essas estão enraizadas no discurso, contribuindo para a permanência ou mudança do poder hegemônico.

\subsection{Peculiaridades do discurso científico}

Com metodologia própria, a ciência adquiriu respeito e credibilidade social por ser a maneira mais competente e objetiva de exprimir a verdade sobre a origem do universo e do próprio homem. Cada revolução científica culminou na rejeição de determinada teoria e no estabelecimento de novas regras e de um novo paradigma científico, não implicando perda da "cientificidade" e da relevância do percurso trilhado anteriormente - as formas de praticar ciência sofreram metamorfoses, porque o mesmo aconteceu com as formas de perceber o mundo. A respeito dessas revoluções e da contínua busca pela verdade, Kunh (2011, p. 27) assinala que "o mundo cientista é tanto qualitativamente transformado como quantitativamente enriquecido pelas novidades fundamentais de fatos e teorias”. Assim, cada revolução científica representa o desenvolvimento de novos conhecimentos e, ao mesmo tempo, transformação social em função do poder e da autoridade que a ciência exerce sob a humanidade.

Nesta busca pela verdade científica, o pesquisador tornou-se mediador entre a ciência e a sociedade, entendido por muitos como um indivíduo capaz de isolar-se de todo o seu repertório cultural e social para dar "voz" à ciência, produzindo um discurso científico livre de contaminações decorrentes da subjetividade, concepção de uma ciência imparcial e pura. Por consequência, o texto científico é tido como expressão e materialização dessa verdade imparcial, na qual o sujeito-enunciador emudece e a ciência fala: tradução de um discurso monológico e fechado (Freitas, 2011).

Sabemos que a produção científica prima por um padrão léxico, em que as 
nominalizações e os termos ou jargões técnicos, acessíveis só aos especialistas, prevalecem. Todavia, além disso, o discurso expresso no texto científico é norteado por regras que buscam imprimir objetividade e impessoalidade, a saber:

(1) emprego usual da $3^{a}$ pessoa do singular (que, acrescida da partícula se, evidencia indeterminação do sujeito) ou da $1^{\text {a }}$ pessoa do plural (sujeito universal); (2) concisão ou economia linguística; (3) precisão ou cuidado máximo com ambiguidades; (4) objetividade ou rejeição a traços inerentes à linguagem afetiva, pautada pela expressão de sentimentos, que o autor vivencia ou que deseja provocar no ânimo do interlocutor; (5) formalismo ou exclusão de termos do dia a dia ou de uso vulgar (Targino, 2010, p. 21).

As peculiaridades apresentadas não fazem inferência à superestrutura do texto científico (Introdução, Referencial Teórico, Metodologia, Resultados e Conclusão), percebemos que elas dizem respeito aos aspectos intrínsecos que orientam a produção textual. Desta forma, disseminar o discurso científico significa pactuar com a forma de expor textualmente tal discurso com base nas imposições estabelecidas por uma instituição: a academia. A autoridade do discurso científico se confunde com a autoridade institucional, tendo em vista a necessidade de observarmos as imposições referentes aos aspectos de padronização do formato do documento, bem como aquelas relativas ao léxico para expressão das ideias e dos achados.

Assim, o "fazer ciência" torna-se um acordo tácito entre quem produz o discurso científico, aqui sinônimo de discurso acadêmico, e as partes envolvidas no citado processo de avaliação e validação desse discurso, uma vez que o meio acadêmico é ambiente controlado e monitorado por regras. O questionamento e/ou destituição dos resultados obtidos por meio do procedimento científico resulta/m de novos argumentos cientificamente construídos; a autoridade do método é mantida como garantia da credibilidade do conhecimento gerado.

Ainda que se trate de um discurso científico, entendemos que cada texto possui objetivos delimitados, refletindo as concepções do indivíduo que são influenciadas por sua função social e pelas relações estabelecidas em sociedade. Hendges (2002, p. 118) afirma que “... o texto é a materialização da linguagem em determinado ambiente social, no qual essa linguagem desempenha uma função específica”. Assim, ao observar as regras apresentadas por Targino (2010) na produção do texto científico, o pesquisador busca escamotear a origem do discurso e de todo trajeto científico por ele percorrido ao realizar a investigação científica. Esta tentativa de construir um texto livre de passionalidade e de marcas sociais é, para nós, prova material de intencionalidade, ou seja, marca de subjetividade científica.

Pactuamos com a opinião de Bakhtin (2006, p. 77) que considera o "texto como uma unidade de linguagem social historicamente construída”, e de Ivanic (1998, p. 78) que, 
alicerçado numa visão socioconstrutivista, afirma: “o texto acadêmico é construído como reflexo de normas e convenções, valores e práticas sócio-historicamente produzidos por um grupo de pessoas que se definem, entre outras coisas, por suas práticas discursivas”. Todavia, os autores não fazem menção ao discurso construído e das ideologias que o compõe. Nossa opinião é de que os indivíduos não são eficazes na tentativa de eliminação das identidades e ideologias que permeiam o discurso por causa da subjetividade intrínseca ao indivíduo que o produz.

Ademais, compreendemos que a capacidade crítica e a racionalidade do indivíduo fornecem subsídios para ele decidir e argumentar, logo, longe de ser a representação da imparcialidade, o seu discurso científico textualizado é um gênero permeado por intenções. Segundo Koch (2010), o sujeito-organizador-planejador constrói o texto partindo de fatores complexos, por exemplo, suas expectativas, convicções e crenças, regras e convenções culturais e sociais, sua inter-relação com outros sujeitos e conhecimentos partilhados, dentre outros - esses fatores complexos imprimem sentido ao texto. No caso de uma investigação científica podemos afirmar que já na elaboração do problema de pesquisa há prioridades e preocupações decorrentes da relação do autor com o mundo circundante e da sua história de vida, tornando-se a primeira manifestação concreta de subjetividade no processo. Por conseguinte, as teorias utilizadas como lente para o estudo e o proceder metodológico da investigação são manifestações resultantes das ideologias que formam a identidade do sujeitoorganizador-planejador (pesquisador).

Goldmann, citado por Japiassu (1975, p. 19), afirma que "toda realidade social é constituída ao mesmo tempo de fatos materiais, de fatos intelectuais e afetivos que estruturam . . . a consciência do pesquisador e que implicam. . . valorizações". Por sua vez, van Dijk (2008, p. 48) considera que "as ideologias (incluindo as científicas) englobam uma (re)construção da realidade social dependente de interesses". Sem deixar de lado os aspectos inerentes do fazer científico - sistematização e organização dos procedimentos que ratificam a validade dos achados - admitimos a subjetividade das interpretações científicas, a qual se faz presente nos objetivos, na justificativa, na teoria de base e nos critérios de coleta e interpretação de resultados que norteiam a investigação. Tal subjetividade é própria da historicidade científica, questão tempo e espaço onde se manifestam a cultura, os paradigmas e anseios sociais, ou seja, maneira pela qual o pesquisador compreende e descreve o fenômeno em análise.

O fato de discordarmos da constituição de uma ciência isenta não implica que discordamos das regras de estruturação do conhecimento científico - a elaboração desta tese é 
uma manifestação explícita dessa aceitação -, apenas consideramos que elas não são plenamente eficazes e efetivas aos propósitos a que se destinam, porque o texto produzido possui um locutor que está inserido histórica e socialmente e que exprime sua concepção de mundo já no momento em que concebe as primeiras ideias acerca do objeto que pretende investigar. Os cuidados excessivos com a manutenção de uma pseudoimparcialidade podem provocar pudores e limitações discursivas por parte dos pesquisadores e, por conseguinte, funcionar como uma "censura" que refreia a sua criticidade e a possibilidade de o mesmo estabelecer o seu ponto de vista de maneira plena, a forma acaba por comprometer a essência. Vilela \& Daros Junior (2005) afirmam: “o cientista ganhou o status que outrora fora do sacerdote, permitindo frequentemente sua cooptação pela classe dominante para justificar com sua obra os interesses hegemônicos e econômicos dessa classe" e, em nosso entendimento isso se reflete, inclusive, na tessitura do discurso de tais cientistas.

Para serem aceitos como publicações, os textos científicos disseminados estão alicerçados num raciocínio capaz de provocar por meio da argumentação efeitos de neutralidade e convencimento. A intenção dos pesquisadores é que esses textos se constituam num discurso que acarrete em aceitação por parte dos pares acadêmicos e demais interessados para que sejam aceitos e publicados. Segundo Koch (1999), as relações ideológicas do discurso envolvem subjetividade intrínseca ao poder da argumentação; para a autora "não existem enunciados neutros e, em decorrência, de que a argumentatividade é uma característica inerente à linguagem humana" (p. 85). Entendemos que a disseminação é uma das formas de conferir ao texto científico o atributo da relevância e persuasão, ou seja, ao ser publicado em periódico, o texto científico passa pela primeira etapa de um processo de avaliação de qualidade e utilidade científica. Isto significa que o proceder científico e as argumentações que ele traz foram capazes de convencer/persuadir os avaliadores.

\subsection{A pesquisa científica como produção ideológica}

Ao trazer à tona a discussão sobre a produção científica como produção ideológica, Minayo (2002, p. 14) afirma que “. . . não é apenas o investigador que dá sentido ao seu trabalho intelectual, mas os seres humanos, os grupos e as sociedades dão significado e intencionalidade a suas ações e a suas construções". Esta afirmação está alinhada com a nossa forma de perceber os discursos científicos, principalmente quando estes discursos decorrem de produções do campo das ciências sociais. Isto porque entendemos que a subjetividade do discurso científico se materializa em ideologias indissociáveis do pesquisador e, por 
conseguinte, de sua produção. André, Henriques \& Alves (2005, p. 8) afirmam que “. . . acreditar que a ciência é exclusivamente objetiva é por si só assumir uma postura ideológica..." - esta postura é completamente contrária à concepção e ao raciocínio desenvolvidos nesta pesquisa.

Empregado inicialmente no sentido político por Marx ao se referir à contraposição de ideias dos burgueses e trabalhadores, o sentido clássico da "ideologia" denota consciência deformada, ou seja, uma ilusão oriunda do discurso da classe dominante para sobrepujar a massa. Todavia, atualmente o termo possui distintas acepções. Em Chauí (2001), a ideologia é definida historicamente e se aproxima da ciência na medida em que o conhecimento da verdade científica não está isolado do mundo e dos fenômenos sociais. Dessa maneira, além de ser o resultado de um processo sistemático de construção do conhecimento, a investigação científica é expressão de pensamentos e percepções de um indivíduo sobre o objeto/fenômeno em estudo. O cientista está imerso na realidade social circundante, e a observação dos procedimentos metodológicos da ciência, as perguntas que elabora, bem como a delimitação do objeto/fenômeno em estudo e as interpretações desenvolvidas, sofrem influência da sua forma de ver o mundo, seus valores e sua história de vida, impossibilitando a constituição de uma ciência completamente neutra.

A visão de mundo do indivíduo está atrelada à sua linguagem, e é por meio dessa linguagem que suas ideias se externalizam, constituindo a tessitura da formação discursiva. Para Fiorin (1993, p. 32) “a formação ideológica impõe o que pensar, uma formação discursiva determina o que dizer" e, desta maneira, elas se completam, se delimitam e passam a representar a visão de mundo de um grupo de indivíduos ou entidade social. Franco (2004) e Cardoso (2006) também considera que a linguagem explicita o pensamento, é a forma de perceber as situações e a opinião que se formula sobre um objeto ou circunstância. Desta forma, entendemos que existe um currículo oculto em contínua formação, gerado com base nas relações sociais estabelecidas. Pois à medida que o indivíduo interage socialmente, acaba por impregnar o outro com suas concepções ideológicas, da mesma maneira que é impregnado por aquelas inerentes dos indivíduos/grupos. E seus enunciados refletem posicionamentos solidificados ou alterados por essas relações - e isto se reflete também nos textos científicos que ele produz.

Campos (2012) considera que a produção do conhecimento é um instrumento estabelecido com base em posturas ideológicas e políticas. Portanto, esse conhecimento científico é um sistema ideológico pelo qual a humanidade apreende o mundo. Pode-se afirmar que, na perspectiva dos autores anteriormente citados, todo o conhecimento 
cientificamente elaborado encontra-se comprometido e impregnado de interesses sociais, portanto: “... não há uma separação, como queriam muitos autores, entre ciência e ideologia" (Fiorin, 1993, p. 29). A pesquisa social é produto de um processo científico que envolve escolhas e julgamentos constituídos com base em uma postura ideológica, ou seja, uma maneira de pensar e conceber o real, a qual é intrínseca ao homem enquanto ser social.

Para Eagleton (1997), a ideologia pode ser compreendida como um texto marcado por distintas histórias e concepções, impregnadas de diferentes fios conceituais. Complementarmente, podemos afirmar que o cientista produz um discurso que sofre influências ideológicas, porque suas apreciações acerca dos achados são justificadas com base em argumentos marcados pelo poder de convencimento. Desta maneira, a ciência não está livre dos aspectos ideológicos intrínsecos ao indivíduo. A opinião do pesquisador e a sua impressão acerca dos fenômenos passam a ser respeitadas cientificamente por meio da sistematização investigativa inerente ao processo científico. Essa investigação condensa um conhecimento que emana do objeto - conhecimento objetivo -, por conseguinte, as reflexões decorrentes ultrapassam o senso comum.

A ciência é, pois, uma ideologia inteligente à medida que busca depurar o real mediante instrumentos científicos, sem negligenciar os próprios interesses (Demo, 1995). O autor a apresenta como fenômeno inerente às ciências sociais por ser produto histórico construído por atores políticos não neutros - diz-se que a ideologia não é suprimida pela ciência, mas manifestada por meio dela de maneira escamoteada, controlada. Para Chauí (2001), os resultados da pesquisa são verdades circunstanciadas historicamente, as quais são apresentadas como dogmas ou criticamente por meio das suas bases. Logo, da sua particularidade e dos interesses a que servem. A autora ainda descreve a ideologia como um corpo sistemático de representações e de normas que nos "ensinam" a conhecer e a agir. A sistematicidade e a coerência ideológicas nascem de uma determinação muito precisa: o discurso ideológico é aquele que pretende coincidir com as coisas, anular a diferença entre o pensar, o dizer e o ser e, destarte, engendrar uma lógica da identificação que unifique pensamento, linguagem e realidade para, por meio dessa lógica, obter a identificação de todos os sujeitos sociais com uma imagem particular universalizada.

Apreende-se que o pensamento ideológico compõe-se de maneira ordenada e busca a universalização, de maneira próxima à elaboração do conhecimento científico. A reprodução da ideologia constitui consenso e poder, os quais, posteriormente, tomam forma de hegemonia (van Dijk, 2008). Entretanto, o autor ressalta que as práticas e instituições no exercício e reprodução da ideologia não se confundem com ela em si. A ideologia é, pois, uma forma de 
cognição social.

Assim, a ideologia aqui discutida quer expressar “... uma posição que o sujeito toma na vida em relação às coisas que faz. E a pesquisa é uma das maneiras que ele vai buscar para firmar, para dar maior validade a esta sua posição" (van Dijk, 2008, p. 48). Trata-se, especificamente, de uma ideologia expressa no conhecimento, nas opiniões e nas representações sociais, desvelada na produção científica. Segundo esse autor, essa estrutura ideológica se fundamenta em metas, princípios e valores proeminentes para a sociedade, os quais são selecionados, combinados e aplicados de maneira que acabam por promover a percepção, interpretação e ação das práticas sociais, favorecendo aos interesses de um grupo (membros de formações ou instituições sociais).

A sociologia aponta que a sociedade se autoproduz de forma perene, da mesma maneira que seus processos e produtos. A ciência, como produção humana, também é recriada de diversas formas na sociedade moderna. É dessa maneira que ela origina o conhecimento científico. Para Morin $(2005$, p. 8) "a ciência é ... complexa porque é inseparável de seu contexto histórico e social". Tal ideia se torna ainda mais significativa quando atrelada à ciência que se produz na área das humanidades e as ciências sociais. Todavia, o desenvolvimento científico precisa imperativamente das seguintes condições: garantir nas instituições e comissões científicas a sustentação e desenvolvimento do pluralismo teórico (ideológico, filosófico) e tolerar/promover/proteger os desvios no seio dos programas e instituições (Morin, 2005). Percebemos que Morin traz um discurso que incita à pluralidade de ideias e de concepções, à diversidade, à transdisciplinaridade e à autonomia como elementos essenciais à construção do conhecimento científico.

Conforme Morin (2005, p. 26), “o conhecimento científico está em renovação desde o começo deste século"; essas mudanças se dão, em geral, por mudanças paradigmáticas promovidas pelas revoluções científicas. Todavia, muito além da extensão e do crescimento, o conhecimento científico se dá por meio das transformações e rupturas, as quais o projetam de um estado para outro, de uma teoria para outra, há efemeridade e contingência no saber científico. A propriedade mutante deste saber se integra à concepção contemporânea de hegemonia apregoada por Laclau \& Mouffe (1987) que é sustentação teórica desta tese.

Schwartzman $(1981 ; 2002)$ traz uma discussão que merece a nossa reflexão. O autor afirma que a politização exacerbada do conhecimento científico gera frustração por parte dos intelectuais, visto que se torna uma ameaça ao próprio campo, corrompendo a autonomia da atividade intelectual. $\mathrm{O}$ autor ressalta que o controle da atividade científica supõe controle dos cidadãos por parte do Estado. Entende-se, pois, que só a tomada de consciência pode, de fato, 
permitir a percepção daquilo que tem sido considerado como marginal e hegemônico no âmbito da ciência.

Já Patto (2006) discorre sobre a relação, explícita ou implícita, que existe entre ciência e ideologia, bem como sobre a desigualdade social, presente nos discursos que são definidos como politicamente neutros, mas que para o autor são instrumentos de exercício do poder, oriundos de uma sociedade dividida, desigual e injusta. Os programas de fomento e políticas relacionadas à ciência são a materialidade das ideias e planos que permeiam os objetivos do Estado. Os órgãos e instituições ligados à ciência no Brasil, a exemplo dos programas de pósgraduação, acabam por replicar tais planos na medida em que se enquadram no panorama de ciência imposto (principalmente em relação às temáticas de pesquisa). Daí a importância da idiossincrasia e formação ideológica para constituição de um movimento contra-hegemônico.

Morin (2005, p. 36) afirma que "a recuperação do controle intelectual das ciências pelos cientistas necessita da reforma do modo de pensar, que, por sua vez, depende de outras reformas, havendo naturalmente, interdependência geral dos problemas". O autor considera que a escola e a universidade são os responsáveis pelos imprintings, os quais atuam na maneira de pensar e agir enquanto cientista - os que sofreram menos imprinting são considerados dissidentes ou discordantes. Entendemos que hegemonia sempre existirá como parte do processo social e é necessária para o estabelecimento da ordem.

Apregoa-se que em ciência é discutível, e isto não se apresenta como uma fraqueza, mas uma preciosa oportunidade de construção em função das múltiplas abordagens e metodologias e impossibilidade de comportamentos idênticos em função da mesma experiência (Richardson, 1999; Martins \& Theóphilo, 2009). Precisa-se de produções que criem ideias, sugiram alternativas, procurem consequências acerca do uso de procedimentos junto aos investidores, gestores e outros usuários.

É nosso interesse investigar as ideologias que emergem da argumentação do discurso científico proferido pelos artigos científicos da área contábil, porque acreditamos que esse discurso pode contribuir para a marginalização de discussões imprescindíveis à área. Essa ideologia contribui para uma identidade de pesquisa vinculada à área contábil; assim, acreditamos ser significativo compreender a concepção do termo identidade.

\subsection{Concepção de identidade}

O termo identidade possui diferentes acepções que a isto se ratifica ao se permear as áreas de conhecimento desde aquelas que se vinculam a uma interpretação mais 
singularmente focada no indivíduo às que se referem ao ator coletivo como representação de grupos sociais.

Freud concebe a identificação como processo de transformação realizado pelo aparelho psíquico (Nasio, 1997) e define o ego como portador de múltiplas identidades que são evidenciadas pelo sujeito no decorrer de sua vida (Chnaiderman, 2001) - segundo essa autora, o termo identidade foi desenvolvido por analistas que elaboraram a noção de self com o intuito de relatar acerca da totalidade da experiência do indivíduo. A ideia de identidade como representativa do sujeito psíquico é severamente criticada pela psicanálise, logo não é um conceito freudiano.

Segundo Le Page (1980), as opções linguísticas, por sua vez, fazem parte de um processo inconsciente realizado pelo sujeito falante que possui diversos papéis sociais e está relacionado às variadas dimensões formativas da identidade social, e os atos de fala decorrentes se constituem em identidade. A linguagem é o indicador da identidade, porém o sentido das palavras não está nelas mesmas, mas nas formações discursivas e ideológicas segundo Orlandi (2001), os enunciados possuem um cunho ideológico.

No âmbito da $\mathrm{AD}$, tem-se o entendimento de identidade atrelado à relação sujeito, língua e história; essa relação é embasada na noção conceitual de indivíduo e de sujeito, refletida pelas teorias de Foucault (relação sujeito e enunciado) e Althusser (relação sujeito e ideologia). Para Orlandi (1996), "não é vigente, na Análise de Discurso, a noção psicológica de sujeito empiricamente coincidente consigo mesmo" (p. 26); a relação entre os fatos sociais (história) e a língua é fundamental para a constituição dos sentidos - é nessa concepção sociológica que se pretende trabalhar o termo identidade nesta tese.

Assim, na acepção sociológica compreende-se a identidade como um processo de elaboração do significado fundado em um conjunto de atributos culturais inter-relacionados que prevalecem sobre outras fontes de significado - em Castells (1999), a identidade é compreendida como a raiz do significado e da experiência de um povo. Esse autor considera a existência de identidades múltiplas como produto da tensão existente no processo de distinção da identidade e do papel social, ou seja, da contradição decorrente da autorrepresentação e da ação social. Neste sentido, entendemos que os papéis sociais instituem funções e são definidos por instituições e/ou organizações, influenciando no comportamento dos indivíduos por meio de acordos estabelecidos entre eles e tais instituições/organizações.

Partindo de uma visão estritamente política, Bauman (2005) considera que a identidade nasce após a crise disciplinadora das funções de integração do pertencimento em decorrência do poder de coerção e convencimento do Estado - percebe-se que a possibilidade 
da identidade como produto institucional é desconsiderada. Todavia, quer por perda de poder, quer por desinteresse na manutenção do Estado como nação, o autor acredita que a concepção de que a globalização dá livre curso à identidade permite que o indivíduo delimite-a, a partir de seus próprios recursos e ferramentas - percebemos, neste caso, a transferência do poder instituidor.

Todavia, "a mesma globalização que intensifica as misturas e pulveriza as identidades implica também a produção de kits de perfis-padrão... para serem consumidos pelas subjetividades, independentemente de contexto geográfico, nacional, cultural etc." (Rolnik, 1997, p. 19). A globalização favorece a formação de identidades globalizadas que sofrem mutação em decorrência dos movimentos de mercado e passam a dividir espaço com uma quantidade restrita de identidades locais fixas. O autor complementa: "esta nova situação, no entanto, não implica forçosamente o abandono da referência” (p. 19). Desta maneira, compreendemos que apesar de haver uma luta no sentido da adesão de uma figura de representação moderna num contexto globalizado, as subjetividades não conseguem se desvencilhar das forças que as constituem.

Concebemos que a identidade se constitui com base na participação ativa e na intencionalidade discursiva dos sujeitos/atores sociais e coadunamos com Castells (1999); Silva (2009), Bauman (2005) e Pallú (2013) ao conceberem a identidade como relação social vinculada a uma definição discursiva e linguística norteada e sujeita a vetores de força e relações de poder, o qual se revela no campo da identidade por meio das normas. A normalização apresenta determinada identidade de maneira discricionária como positiva e desejável (identidade hegemônica), a qual, por consequência, se torna parâmetro para estabelecimento de hierarquia e avaliação de todas as outras identidades como negativas e indesejáveis (marginais).

O processo de produção da identidade oscila entre dois movimentos: de um lado, estão aqueles processos que tendem a fixar e a estabilizar a identidade; de outro, os processos que tendem a subvertêla e a desestabilizá-la. É um processo semelhante ao que ocorre com os mecanismos discursivos e linguísticos nos quais se sustenta a produção da identidade. Tal como a linguagem, a tendência da identidade é para a fixação. Entretanto, tal como ocorre com a linguagem, a identidade está sempre escapando. A fixação é uma tendência e, ao mesmo tempo, uma impossibilidade (Silva, 2009, p. 84).

Percebe-se que a constituição de identidade sem influência dos fatores culturais e históricos refletidos na relação tempo/espaço é impraticável. Quando se diz que a fala e o texto são instrumentos de expressão dessa identidade, a perenidade do sentido constituído para o signo que a representa se torna uma improbabilidade, mesmo que haja uma busca contínua por um sentido fixo e determinado por parte do sujeito. No contexto da teoria 
cultural contemporânea, a identidade se manifesta por meio da representação (traço visível, exterior), concebida como sistema de significação/atribuição de sentido que não guarda qualquer vínculo com a filosofia clássica, mas atrela-se perfeitamente a uma visão pósestruturalista.

Para Butler (1999), a produção da identidade é considerada um ato performativo. Austin (1998) afirma que performativo é o enunciado que, em circunstâncias apropriadas, escamoteia/disfarça o que de fato quer exprimir, realizando parcial ou totalmente uma ação; o enunciado performativo se consolida no fazer - introduz o poder da ação por meio de palavras, ele é uma concepção de linguagem. Os enunciados performativos de identidade precisam ser repetidos, ou seja, a ocorrência isolada do enunciado não guarda efeito relevante, pois é a repetição que dá poder ao ato linguístico na formação de uma identidade; nesse sentido o pronunciamento faz parte de uma rede extensa que auxilia no processo de definir/reforçar a identidade que está sendo descrita.

Todavia, quando autores discutem acerca da identidade, geralmente atribuem a um dizer sobre um "fato" social preexistente, negligenciando a questão de que o dizer do indivíduo está imerso em um contexto mais amplo de atos linguísticos que também guardam relação com esse processo de construção do significado e da própria identidade. É nesta perspectiva de que a identidade é um efeito, um processo de produção, um ato performativo ligado às estruturas discursivas em estreitas conexões com relações de poder, dominação e hegemonia, que buscaremos identificá-las no discurso científico da área contábil.

\subsection{Sobre a opção da teoria hegemônica de Laclau e Mouffe}

Esta seção traz à tona a discussão acerca do sentido do termo hegemonia. Consideramos esta discussão como imperativa ao estudo que realizamos, uma vez que delimita o significado de termos como: ideologia, discurso e hegemonia na perspectiva da teoria hegemônica de Laclau \& Mouffe (1987), bem como justifica a adoção da mesma como fundamentação deste estudo em detrimento das outras teorias hegemônicas. Não estamos apontando a hegemonia discutida em Laclau e Mouffe como a "melhor" base teórica, mas aclarando a sua aderência à tese que elaboramos. Concomitantemente, provocamos reflexões sobre as inconsistências que as outras teorias poderiam gerar a esse estudo por causa da maneira como o fenômeno hegemônico é aqui interpretado.

Apesar de o termo hegemonia ser bastante difundido nos estudos de Gramsci, Bobbio (1982) considera que este autor complementa as bases teóricas do pensamento de Lênin e 
Marx, trazendo contribuições adicionais. O próprio Gramsci considera que o conceito histórico-político de hegemonia foi a mais significativa contribuição de Lênin.

$\mathrm{Na}$ perspectiva leninista, a hegemonia expressa a necessidade de possuir na maioria das classes subalternas (massa camponesa), questão central a ser resolvida teórica e politicamente pelo proletariado e seu partido político. De acordo com Paiva (2001), tal perspectiva possui visão reducionista fundada na ideia de estrutura social a partir de uma determinante econômica (plano político).

$\mathrm{Na}$ formulação gramscista de hegemonia há o deslocamento do fundamento do plano político para o da supremacia fundada na formação econômico-social (cultura, ideologia e direção moral). Neste sentido, a hegemonia se expressa: pelo domínio e pela direção intelectual e moral. A primeira se estabelece por função coercitiva e a segunda por meio ideológico, constituindo a função propriamente hegemônica. Segundo Gramsci $(1995 ; 1999)$ e Katz (2006), o sentido da hegemonia ideológica, comum às sociedades modernas, configurase no exercício do poder instituído por meio de consenso, das alianças e do convencimento no âmbito cultural em detrimento da violência.

Para Portelli (1977), a essência da hegemonia em Gramsci se cristaliza na formação de um bloco ideológico que dá condições de supremacia e permanência no poder à classe dirigente, cujo potencial de atração garante a adesão das demais camadas de intelectuais, materializando a manutenção do monopólio intelectual. Ao considerarmos a hegemonia como a concepção de mundo que impera, podemos afirmar que na medida em que o processo de unidade de uma concepção se estabelece a hegemonia é também estabelecida. No contexto da hegemonia, esse processo se caracteriza como a interação estabelecida entre dirigentes e subordinados no sentido de manter a ordem na atenção de seus interesses.

Entendemos que a teoria hegemônica de Gramsci é uma evolução do pensamento marxista por deixar de tratar a ideologia negativamente como "falsa consciência" e passar vislumbrá-la como "visão de mundo" sob a ótica das classes sociais. Ademais, apesar de conceber a sociedade estratificada em classes, o seu conceito de ideologia também elimina a problemática reducionista, uma vez que os elementos ideológicos articulados pela classe hegemônica não têm uma pertinência, uma classe específica - os intelectuais, que são responsáveis pelas concepções hegemônicas, podem se originar de qualquer classe social.

Nesta perspectiva, os intelectuais têm a função de integrar os conceitos para concepção de uma nova compreensão de mundo e comportamento. Gramsci (1999) entende a academia como organização cultural de sistematização, expansão e criação que trabalha para 
elevar a intelectualidade das camadas populares e formar elites capazes de modificar o panorama ideológico de uma época. Essa concepção é tomada por nós nesta tese, todavia não compreendemos que esse agrupamento de intelectuais se dê especificamente em função de sua classe social.

No primeiro instante da pesquisa, pensamos adotar a teoria da hegemonia de Gramsci como lente teórica desta investigação. Porém, apesar de ela ser o fundamento da teoria que adotamos, percebemos no decorrer do estudo que a mesma não era tão aderente quanto à teoria hegemônica de Laclau e Mouffe ao estudo que realizamos em função de adotarmos como corpus de análise o discurso de artigos científicos definitivos da área contábil. A teoria de Gramsci pressupõe uma sociedade estratificada em classes sociais sobre as quais se exerce poder de coerção e/ou ideológico para o estabelecimento da hegemonia. Todavia, em Laclau e Mouffe (1987) a hegemonia é lastreada em adesão ideológica e estabelecimento de um grupo dominante que atrai adeptos em função da adesão ao discurso do mesmo, ou seja, a hegemonia é estabelecida por meio de aderência a uma concepção de mundo e representatividade intelectual e não guarda relação com classes sociais como em Gramsci.

A atenção de Gramsci se volta à discussão acerca das diferenças estruturais nas formações sociais como fator que explica a dificuldade de conquista do poder em sociedades capitalistas avançadas - a exemplo daquelas situadas no Ocidente (Coutinho, 1999). Para ele, quanto mais "evoluída e organizada" a sociedade, maior resistência será encontrada para destituir o pensamento predominante estabelecido. Neste sentido, o pensamento gramscista vai ao encontro da nossa maneira de pensar sobre o estabelecimento da pesquisa na área contábil, visto que há uma "organização" e "sistematização" hegemônica estabelecida institucionalmente que compactua entre si com a forma de pensar e fazer ciência, impelindo os grupos de pesquisadores (conforme descrevemos na Introdução) a se posicionarem desta ou daquela maneira diante das imposições do sistema.

Acreditamos que a capacidade de produzir conhecimentos é um dos aspectos determinantes da distribuição do poder econômico-político e, atualmente, é uma das maneiras mais eficientes de manutenção do poder hegemônico, já que o desconhecimento/ignorância torna-se arma de imposição ideológica. Além disso, a imposição ideológica pode prejudicar a capacidade crítico-reflexiva dos indivíduos - fato bastante agravante para um país que necessita tomar os rumos do desenvolvimento como o nosso - a este respeito Goergen (1998) ressalta que as nações com melhor índice de produção de conhecimentos posicionam como líderes da economia.

Para Laclau \& Mouffe (1987), a hegemonia tratada por Antonio Gramsci nos cadernos 
do cárcere teoriza o que já se conhece como soft power - poder que mantém a sua autoridade, sem a necessidade de coerção violenta - e faz alusão à questão ideológica. Tal ideologia não pode ser imposta, porque ela pressupõe uma cumplicidade ativa por parte de quem é administrado; tais condições tornam impossível a ocorrência de revolução, ou pelo menos tornam altamente improvável. Esta ideologia cúmplice consolida a hegemonia, e é esta concepção que trazemos à tona ao tratar do discurso científico; em nossa opinião há um acordo tácito e, ao mesmo tempo, indução a um pensamento de ciência que não deixa espaço para a inovação e consequentes contribuições. A união de crenças, convicções ou ideias que determinam as ações, ligadas a um grupo particular ou não, consubstancia a hegemonia ideológica de Laclau \& Mouffe (1987), os quais afirmam que o papel de qualquer política é derrubar o estado das coisas para dar lugar a uma nova ideologia em substituição à anterior em função de determinados interesses do grupo - a concepção marxista vai de encontro do pensamento de Laclau e Mouffe por considerar que se trata de consciência de classe e não aquela representativa de um grupo.

\subsection{Hegemonia em Ernesto Laclau e Chantal Mouffe}

A noção de hegemonia na teoria de Laclau e Mouffe está imersa num contexto em que o discurso se torna elemento principal (Mendonça, 2007). Dessa forma, o estudo referente aos elementos que fundamentam a teoria do discurso permite a compreensão do significado da hegemonia para Laclau e Mouffe.

Para Ferreira (2011, p. 13), “o discurso é o terreno primário no qual a realidade se constitui. Ele toma como pressuposto a ideia de que a linguagem é constituidora da realidade e, portanto, ela só existe dentro de um discurso que a torna possível”. Nesta perspectiva, o discurso é comprendido, torna-se ferramenta constituidora da existência e do significado.

Alves (2010a; 2010b) afirma que o sentido de um determinado evento social se constitui com base em um sistema de relações, cujo estabelecimento se dá por meio do discurso. Todavia, destaca que, diante da complexidade e dinâmica das relações sociais, não há possibilidade de fixação de um sentido único, constitui-se sentidos parciais que são mantidos em determinado espaço de tempo.

Para Laclau \& Mouffe (1987), a prática da articulação no discurso se fundamenta no caráter parcial da fixação de significado; o caráter parcial, por sua vez, decorre da abertura do social, o qual provém do contínuo extravasamento do discurso no campo da discursividade. Nesse sentido, o discurso pressupõe a impossibilidade de encontrar o "real", o "verdadeiro", o 
“correto", o "objetivo", bem como a quebra de perspectivas idealistas (Laclau, 1986). Mendonça (2007) destaca que o campo da discursividade é espaço social onde acontecem as disputas discursivas, prática social significativa de natureza material.

Nesta acepção, o significado do discurso é concebido em função das práticas articulatórias entre elementos, ao passo que também modifica as suas identidades - são relações entre os elementos de uma formação discursiva. Dessa maneira, pode-se afirmar que a hegemonia estabelecida por meio do discurso é precária e contingente, porque o discurso fundamentado em práticas articulatórias se configura, conforme Laclau (1986), em uma tentativa parcial de sustentação do sentido.

As relações contemporâneas são norteadas por uma pluralidade de centros constituidores de identidades como implicação de sua complexidade. Tais identidades podem ser hegemônicas num processo de articulação, no processo de constituição do discurso e na disputa pelo significado da realidade (Laclau, 1986).

Todavia, na perspectiva de Laclau, o discurso é concebido como o deslocamento de situações que propiciam a desestrutura, tornando necessário o reestabelecimento do senso de identidade à medida que os elementos de conexão são afrouxados. Em virtude disso, Laclau (1986) concebe o indivíduo como sujeito errante em busca de uma sutura de algo que lhe falta e que ele não é capaz de identificar - quando a identificação do que lhe falta ocorre, ela é percebida como uma aposta num projeto transitório.

A manipulação por meio do discurso e práticas de linguagem determina a posição do dominado e dominador. Ao transpor tal concepção ao sentido da teoria da hegemonia de Ferreira (1986), tem-se a demarcação de atores que possuem posição política alta, a qual é exercida por uma minoria intelectual; e atores que possuem posição política baixa, vivenciada por uma maioria simples - nesta acepção, o discurso é a representação de demandas particulares.

Chia (2000) destaca a dificuldade de compreensão de como uma dada realidade se estabelece em primeiro plano, ou seja, como uma realidade se manifesta hegemônica em detrimento da realidade marginalizada. Tal resposta pode ser explicada tomando por base as práticas discursivas, visto que elas são uma parte da socialização ideológica, e nelas a economia política mais ampla e contextos históricos de hegemonia tornam-se práticas materiais (Boje, Oswick, \& Ford, 2004).

Laclau \& Mouffe (1987) enfatizam a ampliação da recomposição política e da hegemonia com base na ideia de direção intelectual, corroborando com a necessidade de uma liderança intelectiva e moral para além da aliança de classes, conforme propõe Gramsci. 
Permite-se, portanto, o abandono de posturas corporativistas que permitem aos grupos sociais se unirem aos interesses de outros grupos.

A teoria do discurso de Laclau (1986) permite a evidenciação dos pontos de exclusão; esse autor acredita que não se trata de eliminar as formas de poder, dada a impossibilidade e o desejo da existência de múltiplas ideologias. Entretanto, é essencial que essas ideologias sejam desconstruídas e explicitadas. Laclau e Mouffe (1987) acreditam que o estabelecimento de uma relação hegemônica representa a tentativa de constituir uma relação de ordem; desta forma, o discurso hegemônico tem caráter essencialmente sistematizador e aglutinador.

A concepção de Laclau \& Mouffe (1987) evidencia a dinâmica da hegemonia, dada a sua incompletude, precariedade e contingência. Ao fazer uma analogia da concepção hegemônica de Laclau e Mouffe com aquelas de Lênin e de Gramsci, Mendonça (2007) destaca que

um elemento decisivo para entendermos a ideia de hegemonia no contexto discursivo é que, não há como necessariamente estabelecermos previsões de quais identidades políticas assumirão papéis de representação social. Não há aqui a "segurança" do projeto político marxista que previa que a entidade proletária assumiria as lideranças moral, intelectual e política da sociedade industrial.

O caráter hegemônico aglutinador, sistematizador e constituidor de ordem não perene, anteriormente citado, infere que a concepção de hegemonia vinculada não pode ser utilizada para descrição ou enquadramento em momento político hegemônico, mas para evidenciar a ausência de ordem política hegemônica do momento em questão.

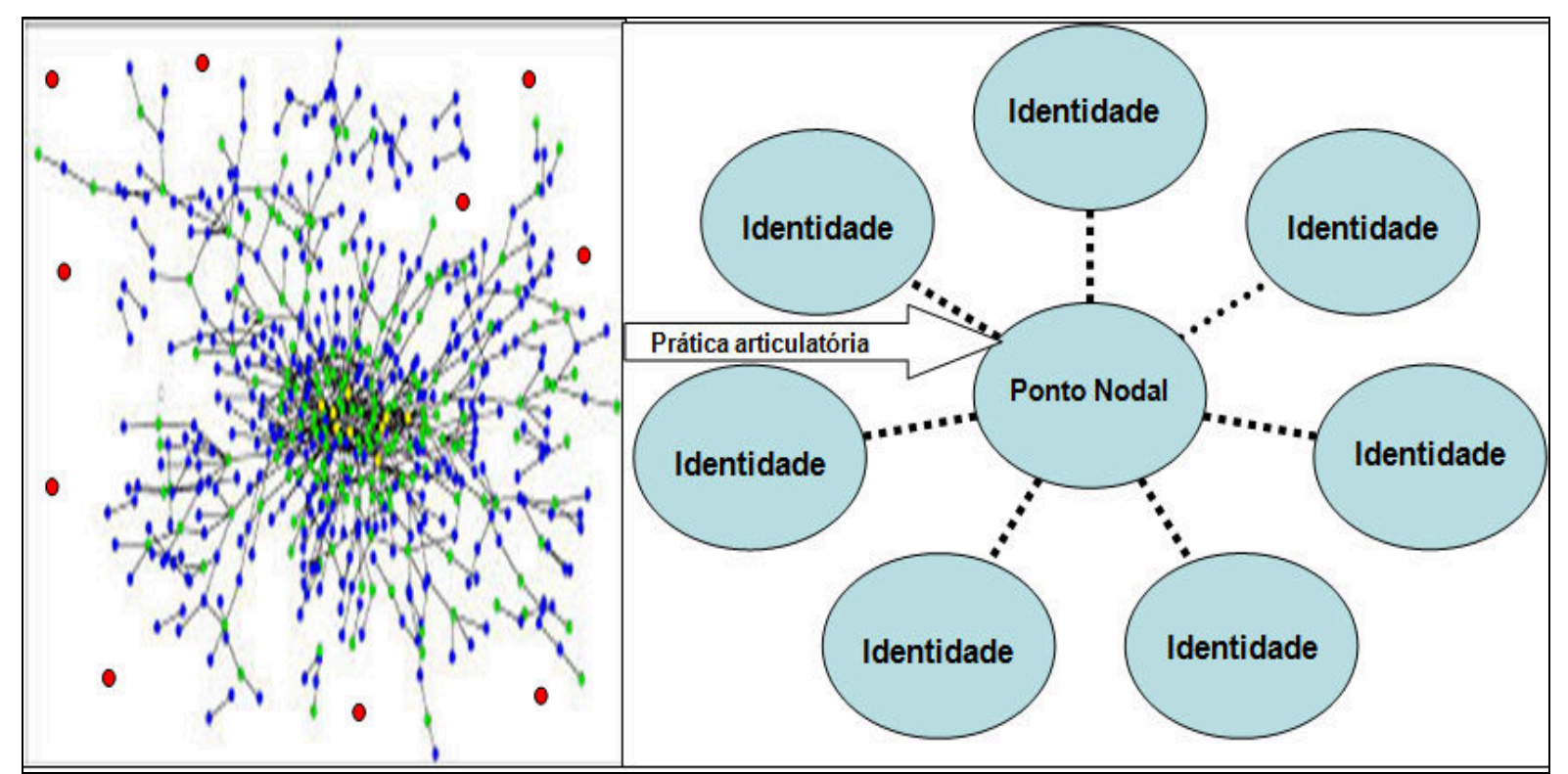

Figura 4. Estabelecimento da concepção hegemônica em Laclau e Mouffe (1987).

A Figura 4 evidencia a constituição de uma ordem hegemônica que parte de um 
discurso particular (identidade) para representar discursos ou identidades que se encontravam dispersos. A prática articulatória é que constitui e organiza as relações entre o discurso privilegiado (ponto nodal), o qual fixa parcialmente os sentidos dos discursos, vinculando elementos que, inicialmente, não estavam articulados entre si. Destaca-se que, partindo dessa ideia de hegemonia, o ponto nodal de articulação de multíplices identidades se esvazia à medida que incorpora sentidos indeterminados, passando a representar as identidades que a ele se aglutinam.

Mendonça (2007) é contundente ao afirmar que "sem representação não há hegemonia, visto que a relação de representação é o momento em que uma determinada particularidade consegue universalizar seus conteúdos, articulando em torno de si outras particularidades que anteriormente não estabeleciam qualquer elo". Cada formação hegemônica contém um discurso privilegiado que representa todas as identidades a ele aglutinadas.

O entendimento da proposta de discurso de Laclau, na elaboração de uma realidade, pressupõe a delimitação de categorias centrais, as quais expressam suas concepções. Segundo Ferreira (2011), tais categorias são: o caráter aberto do social, a multiplicidade de posições que podem ser ocupadas por um sujeito na sociedade contemporânea; os antagonismos inerentes às práticas sociais e à teoria da hegemonia, temporariamente estável, para constituição das identidades.

Em Butler (2000) são apresentadas condições ou dimensões necessárias à constituição da hegemonia exposta por Laclau e Mouffe, conforme a seguir:

Tabela 2:

Condições para o estabelecimento da hegemonia em Laclau e Mouffe.

\begin{tabular}{ll}
\hline \multicolumn{1}{c}{ Condições/Dimensões } & \multicolumn{1}{c}{ Descrição } \\
\hline Desigualdade de poder & A instituição do poder nas mãos de determinado grupo depende da \\
habilidade que possui para apresentar seus objetivos, inicialmente \\
particulares, como compatíveis e representativos com os anseios de outros \\
grupos.
\end{tabular}


complexo ambiente social da contemporaneidade. Ademais, a volatilidade e a dinâmica das relações, estabelecidas entre o discurso privilegiado e as concepções particulares (identidades) na cadeia de equivalências, favorecem a agregação ou afastamento das mesmas. As concepções originalmente antagônicas, que constituem as identidades, dão liberdade para sua aglutinação ou afastamento. Não há qualquer segurança de que o ponto nodal (discurso ou grupo social) consiga articular distintos discursos ou grupos sociais.

\subsection{Hegemonia e a discursividade}

De acordo com Nascimento (2011, p. 91), “o conceito de hegemonia é central na teoria do discurso. A hegemonia é o discurso que se tornou naturalizado, fixo. Isto ocorre em função de o discurso abarcar interesses de diferentes grupos, universalizando demandas particulares" - pode-se afirmar que o discurso hegemônico representa ideologias e constitui identidade.

Ao fazer uma analogia da concepção hegemônica de Laclau e Mouffe com aquelas de Lênin e Gramsci, Mendonça (2007) destaca que a compreensão da ideia de hegemonia no contexto discursivo se fundamenta na impossibilidade de estabelecer previsões acerca de quais identidades assumirão papéis de representação social. Essa representação se dá de maneira não perene, uma vez que a hegemonia dela decorrente tem caráter parcial de fixação de significado, porque decorre do contínuo extravasamento do discurso - tem-se que a relação hegemônica estabelecida pelo discurso é aglutinadora, sistematizadora e constituidora de uma ordem não perene, porque essa relação é mecanismo de fixação de identidades para manutenção do domínio.

Nesse sentido, o discurso pressupõe a impossibilidade de encontrar o "real", o "verdadeiro", o "correto", o "objetivo", quebrando as perspectivas idealistas que buscam dar conta das situações concretas. Ratifica-se a ideia da dinâmica morfológica das concepções contemporâneas como fruto da intervenção da consciência e vontade na história, as quais são carregadas de transitoriedade e contingência. Interessa-nos, portanto, evidenciar as ideologias que emergem do texto de discurso científico para compreender a hegemonia que se estabelece por meio delas, uma hegemonia capaz de fomentar replicações e que tem provocado apatia e silenciamentos no que diz respeito à inovação e às contribuições no ambiente científico da área contábil.

De acordo com Chia (2000), a realidade moderna é continuamente estabelecida e sustentada por meio dos atos discursivos agregativos da realidade construída, que se 
materializam em uma versão particular da realidade social com a exclusão de outros mundos possíveis. Neste sentido, as práticas discursivas e linguísticas são componentes da socialização ideológica. Segundo Reed (2000), alguns agentes possuem vantagens poderosas para manipular partindo do discurso e das práticas de linguagem. O discurso é um sistema de relações que torna possível a atribuição de sentido para o evento retratado, por isto diz-se que ele é matéria-prima constituidora da existência. Para esse autor a linguagem constrói a realidade e, portanto, ela só existe dentro de um discurso que a torna possível. Da mesma maneira, a realidade circundante guarda significativa influência sobre a forma com que os indivíduos interpretam as produções do campo da discursividade.

\subsection{Práticas que organizam a divulgação do conhecimento}

Além de expressar aderência à política editorial de um periódico e aos aspectos de cientificidade consolidados em determinada área de conhecimento, a publicação de um artigo científico representa a difusão de ideias e achados pactuados por atores que, direta ou indiretamente, contribuem para a constituição do discurso proferido. Segundo Frezatti, Nascimento e Junqueira (2009, p. 7), “... o sistema de publicação funciona dentro dos paradigmas estabelecidos pelos periódicos, o que torna a inovação um risco quando o construto teórico e metodológico fugir do mainstream estabelecido". Com base na ideia dos autores, entendemos que as normas e as perspectivas estabelecidas pelo periódico tanto podem favorecer a um dado universo de pesquisa, quanto podem limitar o avanço do conhecimento e exploração de temas emergentes. Essas limitações favorecem a discursos repetitivos, cujo foco de análise torna-se trivial, promovem poucos debates intelectuais e tornam mais lento o crescimento da área.

A mencionada difusão tem sido matéria relevante na agenda da Associação Nacional de Pós-graduação e Pesquisa em Administração [Anpad] ,a qual elaborou um manual de orientação de boas práticas de pesquisa, objetivando “ajudar os periódicos brasileiros a alcançar elevado desempenho e a ampliar o seu impacto como fonte de pesquisa referencial nas áreas de Administração e Contabilidade” (Anpad, 2010, p. 1). A perspectiva dessa associação é de que, ao adotar tais práticas, essas áreas se firmem como campo de produção do conhecimento.

A estrutura da equipe editorial e sua relevância para a continuidade, a qualidade e a cientificidade das produções de um periódico científico são assuntos abordados no mencionado manual. Nessa abordagem, o elemento central da referida estrutura é o Conselho 
Editorial, o qual imprime sua concepção de mundo a outros pesquisadores à medida que delineiam as linhas de pesquisa, caracterizam e selecionam textos baseados em determinado rigor científico. É interessante tratarmos sobre o fato de que essa concepção ou "rigor científico" é apenas uma dentre as possibilidades de expressão da forma de conceber a ciência, a qual representa um grupo hegemônico circunstanciado em um tempo histórico que delimita seu espaço ideológico ou, até mesmo, desbrava e conquista territórios que sequer foram explorados. Acreditamos que as hegemonias culturais/ideológicas são estabelecidas em determinadas áreas de conhecimento por causa da negligência, apatia ou descomprometimento de indivíduos, ou seja, falta de visões alternativas plausíveis que ofereçam contraponto.

Não nos cabe, portanto, conceber como "boas" ou "ruins" as práticas científicas apresentadas. Pensamos que o termo "boa" já traz em si um pré-conceito em relação a outras formas de concepções científicas. Todavia, desde a década de 90 , momento da aceleração das publicações, até 2010, ano de publicação do manual de "Boas Práticas da Publicação Científica", não havia um tratamento objetivo para a área de Administração e Contabilidade sobre as especificidades nele contidas. Em vez de ponderarmos sobre a existência de práticas "boas" ou "ruins", focalizaremos no fato de que o que se entende por boa prática, por vezes, corresponde a um determinado modelo de ciência a ponto de nos sentirmos por ela representados e a ela representar.

Para Oliveira (2002), a aceleração da publicação em periódicos científicos, anteriormente mencionada, se deu em consonância com a avaliação quantitativa da produção científica pela Coordenação de Aperfeiçoamento de Pessoal de Nível Superior (CAPES) e Instituições Federais de Ensino Superior (IFES), bem como com o surgimento da pósgraduação. Mas, segundo a autora, a qualidade - mensurada com base em padrões internacionalmente considerados relevantes - ainda era incipiente. Em decorrência dessas constatações, nossa interpretação primeira é de que a publicação contábil brasileira foi dinamizada em função de circunstâncias que pouco favorece a organização estrutural dos periódicos e a própria maturação da pesquisa são "produções oportunistas".

Entendemos que produções maturadas decorrem de projetos de pesquisas que se solidificam no decorrer de um tempo relativamente maior que aquele necessário para atender às prerrogativas impostas e gozar dos ditos incentivos de carreira oferecidos aos docentes. Além disso, entendemos também que há uma necessidade política do grupo hegemônico de atenção a características a que a autora se refere como "aquelas internacionalmente consideradas" para fins de aceitação e visibilidade internacional dos estudos nacionais, uma 
subordinação/vinculação ideológica. Segundo Frezatti et al (2009, p. 7), “os tempos de crescente globalização exigem que os pesquisadores estejam muito atentos ao desenvolvimento dos demais centros, não apenas acompanhando contemplativamente, mas trazendo contribuições”. A nosso ver, o maior problema na área contábil centra-se no fato de que os centros internacionais de pesquisa científica a que direcionamos nosso olhar, vislumbrando paridade ou contribuições, em geral, nada ou quase nada têm de similaridade com o Brasil, vivem situação histórica, social, política, econômica e cultural, extremamente, distinta daquelas que enfrentamos.

Retomando a discussão sobre a publicação de conhecimento científico, temos que tanto a concepção do autor sobre a publicação científica, quanto sobre as regras impostas pelo periódico, veículo responsável pela disseminação de conhecimentos científicos, refletem (ou deveriam refletir) sobre a decisão do pesquisador ao submeter um artigo à avaliação de determinada revista científica. Desta maneira, ou o autor se sente contemplado pelo periódico em função das concepções que coaduna e submete o seu trabalho, ou o autor se sente "obrigado" a comungar das ideias impostas para disseminar as suas próprias e atender às prerrogativas imperativas de avaliação, ou o autor se sente demovido de apresentar suas contribuições científicas e não as publica, se cala.

Cordeiro (2008, p. 1) entende o periódico científico como lugar de veiculação de um discurso prescritivo, uma prescrição materializada nas “... opções que resultam em escolhas do que se diz e do que não se diz, do que se publica e do que não se publica ...”. Neste sentido, são expressas as formas mais legítimas e adequadas de produção científica por meio das temáticas prediletas, teorias de base, autores e linhas de pesquisa, por exemplo. Segundo esse autor, as convenções apresentadas acabam por demarcar territórios específicos, tanto no campo intelectual mais amplo, quanto em campo intelectual restrito. Tensões ideológicas que enriquecem e favorecem ao desenvolvimento e estudo em uma área de conhecimento.

Assim, ao imprimir sua concepção de mundo, o Conselho Editorial, representado significativamente na pessoa do Editor do periódico, promove a formação de três grupos: o primeiro, constituído por simpatizantes das ideias hegemônicas (conformidade com sua visão de mundo); o segundo, por marginalizados (anti-hegemônico em função de suas próprias concepções) e, paralelamente; o terceiro grupo, constituído por seguidores que não chegam a trazer contribuições para a área. Este terceiro grupo deve ser alvo de preocupação por formadores, pois se constitui como grupo por se tornar adepto daquilo que os discursos acadêmicos propõem como verdades para o seu tempo. Quanto aos simpatizantes e aos marginalizados, podemos pensar que se trata de opções epistemológicas diferentes; no 
entanto, o terceiro grupo é basicamente resultado de falta de formação. Por isso Morin (2005, p. 150) afirma que “... é preciso deixar de sonhar com uma ciência pura, uma ciência libertada de toda ideologia", afinal, seja por meio dos métodos e temáticas adotados, seja por meio das ideias discutidas, os autores constroem uma retórica científica, cuja aderência às ideologias do periódico (objetivos e missão) se manifesta no aceite encaminhado aos mesmos pelo editor.

Conscientes de que o periódico científico está impregnado por uma ideologia representativa do pensamento de um grupo de intelectuais de determinada área de conhecimento, buscamos conhecer a Revista Contabilidade \& Finanças - aspectos relacionados à sua Política Editorial e a Equipe Editorial, bem como alguns artigos por ela publicados. Tomamos tais aspectos como significativos para análise porque acreditamos que contribuem para a constituição de uma identidade ao conhecimento científico produzido e publicado pela área contábil.

\subsection{A equipe editorial de um periódico}

Em geral, a motivação primeira de uma investigação científica decorre do interesse pessoal do pesquisador. Esse interesse primeiro é natural e esperado e se origina dos valores culturais, do conhecimento acumulado e das relações sociais estabelecidas - base de uma concepção de mundo fundada na relação entre o contexto social e o contexto histórico, tratada no capítulo "História da Investigação".

Porém, o interesse primeiro do pesquisador não é justificativa suficiente/significativa para sustentar a existência de um periódico científico, por exemplo. Trzesniak (2009, p. 88) faz uma reflexão sobre os fundamentos e representatividade da estrutura da equipe editorial de um periódico científico como condição precípua para a sua continuidade e afirma: "não é saudável um periódico científico existir unicamente com base no sonho e no entusiasmo de uma pesquisadora ou de um pesquisador, embora encontremos essa situação com frequência muito maior que o desejável". Concordamos com o autor e entendemos que os riscos decorrentes da ação de um único(a) pesquisador(a) como responsável(is) por um periódico científico são refreados com a constituição de uma Equipe Editorial, assim, antes de discutir sobre o nosso contexto de pesquisa, consideramos salutar apresentar considerações relacionadas à composição desse conselho de um periódico científico.

A Figura 5, a seguir, nos permite conhecer as subequipes que, segundo Trzesniak (2009), geralemente constituem uma Equipe Editorial de um periódico científico: 


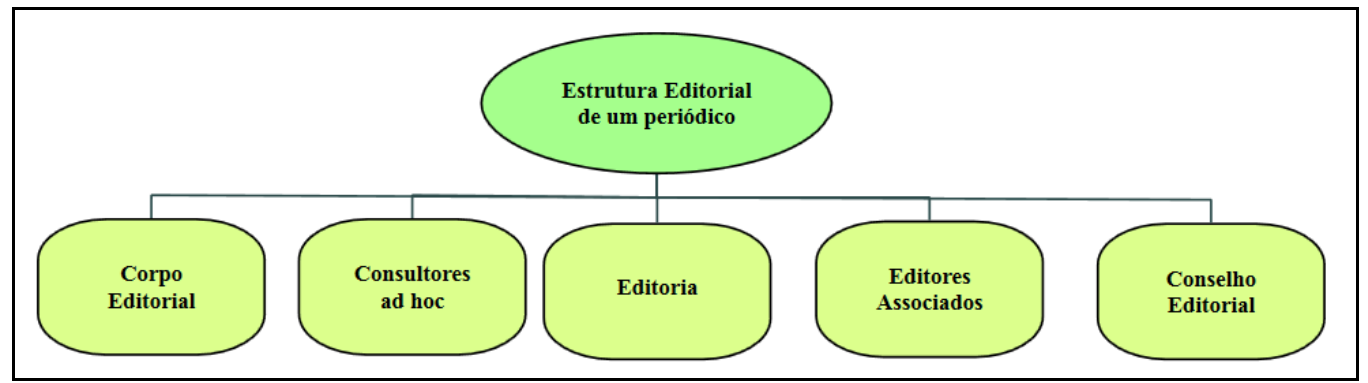

Figura 5. Composição do Conselho Editorial de um periódico científico conforme Anpad.

A estrutura editorial é formada pelo Editor, também denominado Editor-chefe ou Editor-geral, aquele cujo nome vincula-se diretamente ao periódico por ser nessa estrutura a sua representação máxima; pelo Conselho Editorial ou Conselho/Comitê de Política Editorial, que é responsável pela conjuntura política (ideológica) do periódico, atribuindo ao mesmo uma "personalidade"; por Editores Associados, também conhecidos como Adjuntos, de Área ou de Seção, cuja responsabilidade se vincula a determinada(s) linha(s) de pesquisa; pelo Corpo Editorial Científico, que contribui individualmente à medida que é requisitado pelo Editor-chefe; e pelos Consultores Ad Hoc (pareceristas, avaliadores, revisores e árbitros) que analisam os artigos e emitem sobre estes uma opinião embasada nas diretrizes e nos interesses do periódico. É interessante ressaltar que os membros da Equipe Editorial podem exercer diferentes funções no periódico, à exceção do Editor, que só pode acumular competências inerentes a essa função e àquelas decorrentes do Conselho Editorial.

Passemos agora a conhecer algumas especificidades relacionadas às competências das subequipes (grupos) que compõem a Equipe Editorial. A nosso ver, tais especificidades: elucidam sobre o funcionamento; evidenciam as responsabilidades atribuídas a cada grupo; delimitam o poder exercido pelos membros dessas equipes - tanto no processo de elaboração da Política Editorial quanto na avaliação do conhecimento disseminado, concomitantemente.

De acordo com Trzesniak (2009), quando não há divisão entre tarefas administrativas e científicas, o Editor Chefe/Geral assume as funções de Editor Gerente/Executivo e de Editor Científico. Enquanto o primeiro direciona suas ações a aspectos administrativos do periódico, o segundo ocupa-se do processo de avaliação dos artigos; portanto, precisa ler todos os artigos que deseja publicar. A decisão de publicação é consubstanciada pelos pareceres (emitidos pelos Consultores Ad Hoc), cujo objetivo é instrumentalizar o processo com base em opinião argumentada. Todavia, antes mesmo de chegar aos pareceristas, o material encaminhado pode ser retirado do processo de submissão baseado no julgamento do Editor.

Tobochnik (2008) ressalta quão determinante é o papel do Editor de um periódico, dado que todo conteúdo disponibilizado ao público depende, prioritariamente, da análise 
documental que ele realiza (desk review). Nesta concepção, o Editor torna-se o mentor (guide keeper) do processo editorial. A originalidade e a relevância do artigo para a área de atuação do periódico, a qualidade da linguagem, as regras de formatação/apresentação geral e demais aspectos da política editorial são ponderados pelo Editor. Dessa maneira, podemos afirmar que a produção intelectual do autor é estereotipada pelo editor à medida que este faz especificações acerca do produto e detém o julgamento final, cujo posicionamento pode ser, inclusive, contrário àquele emitido pelos revisores do estudo.

Por sua vez, o Conselho Editorial se constitui numa equipe capaz de convergir forças/potencialidades, que objetivam solidificar e perpetuar as atividades de um periódico científico. Isto porque, para além do cumprimento da obrigatoriedade normativa, esse Conselho é responsável pela essência ideológica do periódico, ou seja, as visões e experiências individualizadas dos seus integrantes são ordenadas em um projeto de política científica e substancializadas em elementos como missão, objetivos, escopo, dentre outros. Ao auxiliar no processo de definição dos caminhos a serem trilhados por uma área de conhecimento, esse colegiado gera simpatizantes, marginalizados e atrai os pesquisadores em formação - grupos sobre os quais discutimos no Capítulo 1. Assim, o denominado como Conselho Editorial (ABNT, 2003), ou "Conselho de Política Editorial" ou "Comitê de Política Editorial" pela (Anpad, 2010) deve ser um grupo de pesquisadores representativos de entidades como: 


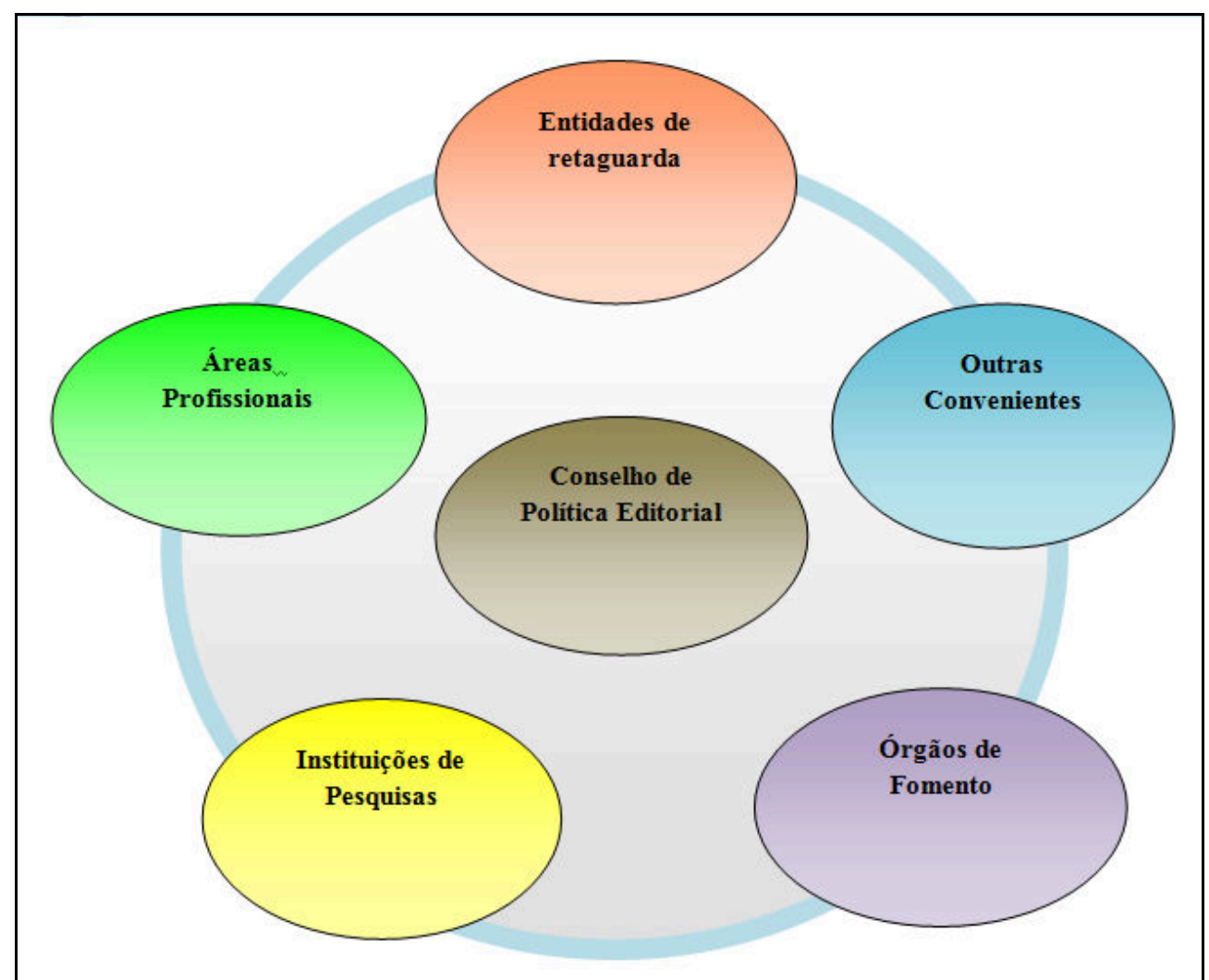

Figura 6. Entidades representadas pelo Conselho Editorial de um periódico segundo Trzesniak.

Ao citar as entidades representadas na Figura 6, Trzesniak (2009) sinaliza a necessidade de que o periódico tenha uma retaguarda que lhe dê respaldo intelectual para a continuidade das suas atividades, não apenas pela influência nominal ou financeira. Entendemos que o fato de experienciarem os conhecimentos da área de formas específicas/distintas, ainda que no exercício de atividades profissionais idênticas ou similares, os representantes dessas entidades direcionam esforços sinérgicos em torno de um mesmo objeto: a publicação do conhecimento científico. Tal fato impele que esse conhecimento atenda às expectativas e materialize contribuições aos interessados diretos (universidades, fundações, empresas...) e indiretos (sociedade em geral), agregando qualidade a esses estudos. Segundo Loureiro (2003), o fluxo informacional dos artigos se dá por uma disseminação intrapares e/ou extrapares; enquanto a primeira acontece entre os especialistas de uma mesma área de conhecimento, a segunda alcança os especialistas de outras áreas que realizam trabalho multidisciplinar.

Outro aspecto que merece menção, decorrente da formação do Conselho Editorial de uma revista, é a possibilidade de integração entre a academia e a sociedade, vulgarização/popularização do conhecimento científico. Essa vulgarização encurta distâncias e oportuniza a promoção da utilidade da pesquisa, e o conhecimento gerado passa a contar com um contingente maior de interessados materiais, não apenas potenciais. Nestes termos, a 
ciência cumpre o seu objetivo maior: desenvolvimento da área, disseminação de conhecimento, integração entre os pares na academia e integração entre esses pares e a sociedade e, por conseguinte, efetivação da utilidade/relevância social em detrimento de estudos que possuem interesses oportunistas.

Os Editores Associados são pesquisadores que se disponibilizam a colaborar com o Editor-chefe no que diz respeito às atividades editoriais; mais precisamente, o Editor Associado participa do processo de avaliação dos artigos, indicando avaliadores e verificando o texto final. Apesar de a decisão cabal de publicação ser de competência do Editor, essa subequipe, também, se envolve no processo de aceite do artigo e, por conseguinte, sua publicação. O Editor Associado é designado por linha de pesquisa, e tanto pode estar vinculado a uma linha de tradição da revista, quanto fomentar uma linha emergente. Segundo Trzesniak (2009), é preferível que esse pesquisador pertença à instituição distinta daquela a que o periódico científico está vinculado.

Em relação ao Corpo Editorial, Trzesniak (2009) e Anpad (2010) o definem como um colegiado multi-institucional composto por especialistas vinculados às áreas do saber a que o periódico se dedica, distribuídos tanto científica quanto geograficamente. É importante ressaltar que o Corpo Editorial não tem influência direta sobre a produção do conhecimento, seus componentes são conselheiros do Editor e oferecem sua parcela de contribuição de maneira individualizada, quando consultados - neste sentido, podemos afirmar que o Corpo Editorial tem a possibilidade de influenciar a opinião do Editor.

Após realizarmos esta incursão acerca da importância e do papel dos conselheiros que compõe o corpo editorial de um periódico científico, apresentaremos no capítulo a seguir o contexto desta investigação: a Revista Contabilidade \& Finanças. Trataremos do escopo dessa revista, ou seja, tanto as regras editoriais quanto aspectos que caracterizam os componentes do seu corpo editorial, isto porque acreditamos que influência direta e indireta dos mesmos nas ideologias que emergem dessas regras e das publicações que o periódico veicula. 



\section{CONTEXTO DA INVESTIGAÇÃO: REVISTA CONTABILIDADE E FINANÇAS}

Neste capítulo apresentamos o contexto de nosso estudo: a Revista Contabilidade e Finanças (RC\&F). Tratamos analiticamente das regras editoriais, da composição da sua equipe editorial e das suas fontes referenciais nos últimos seis anos. Em seguida, descrevemos de maneira sistematizada o trajeto que percorremos para a seleção dos artigos analisados, bem como para a realização das entrevistas junto aos pesquisadores da área contábil.

\subsection{Regras editoriais: Revista Contabilidade \& Finanças}

A Revista Contabilidade \& Finanças (RC\&F), contexto deste estudo, é um periódico do Departamento de Contabilidade e Atuária da Faculdade de Economia Administração e Contabilidade da Universidade de São Paulo (FEA/USP) que conta com suporte financeiro CAPES, do Conselho Nacional de Desenvolvimento Científico e Tecnológico (CNPq), e Fundação Instituto de Pesquisas Contábeis, Atuariais e Financeiras (FIPECAFI) e Programa de Apoio às Publicações Científicas Periódicas da USP (SIBi). Esse periódico teve sua primeira edição publicada em outubro de 1989 com o objetivo de redirecionar e difundir a publicação científica dos professores do Departamento FEA/USP, através da ampliação da comunicação (Revista Contabilidade \& Finanças, 2015). Atualmente, a RC\&F tem favorecido a discussões e troca de experiências entre pesquisadores nacionais e internacionais de diversas linhas de pesquisa e, ainda, de outras áreas do conhecimento.

Quadrimestral e gratuita, a RC\&F foi inspirada num modelo de periódico francês e denominada, inicialmente, como Caderno de Estudos. A adoção desse modelo (modesto, simples e barato) tornou-se alternativa coerente diante da escassez de recursos, à época. Atualmente a revista é indexada a seguintes bases: Scientific Electronic Library Online (SciELO), EBSCO Publishing, ProQuest, Base Atena, Gale - Cengage Learning, Red de Revistas Científicas de América Latina, el Caribe, España y Portugal (Redalyc), Scientific Periodicals Electronic Library (SPELL) e Sumários de Revistas Brasileiras (Sumários) (RC\&F, 2015). A indexação a essa bases favorece a ressonância do conteúdo científico disponibilizado por essa revista, tornando-a um veículo de expressivo significado na condução e disseminação de estudos desenvolvidas na área contábil e, por conseguinte, na forma de fazer e pensar a pesquisa, principalmente no Brasil.

Dados coletados no site da CAPES em 2015 atestaram que, em consonância com 
critérios definidos pelo Conselho Técnico-Científico da Educação Superior (CTC/ES), o comitê de consultores de da área de Administração, Ciências Contábeis e Turismo atribuiu a RC\&F classificação A2, em 2013. No site da revista consta que esse conceito é fruto de um esforço iniciado há 25 anos, todavia que a nota do órgão regulador não é o centro de sua preocupação, e sim, a divulgação de conhecimento relevante. Para atrair esse "conhecimento relevante", o periódico enfrenta a concorrência do mainstream e dos periódicos nacionais, atentando-se também a necessidade dos pesquisadores de publicar em periódicos internacionais. Ainda segundo informações do site, para vencer esses desafios a RC\&F mantém: regulamento formalizado e forte estrutura de governança; pluralismo ontológico e epistemológico; publicação em português e inglês ou espanhol e inglês; pagamento de custos de tradução dos trabalhos aceitos; indexações eficientes fomentando maior oportunidade de citação; fontes de financiamentos adicionais à FIPECAFI, junto ao Sistema Universitário de Bibliotecas (SIBI) e Conselho Nacional de Desenvolvimento Científico e Tecnológico (CNPq); incentivo a pesquisas que se relacionem com o escopo da Revista; profissionalização da estrutura de apoio interna e externa e comunicação tempestiva com autores, leitores e revisores.

A missão e os objetivos do periódico retratam os interesses da revista, no caso da RC\&F a missão e os objetivos apresentados a seguir atendem as orientações do Manual de Boas Práticas de Pesquisa da Anpad (2010):

Tabela 3:

Missão, objetivos e composição da equipe editorial da $R C \& F$

\begin{tabular}{|c|c|c|}
\hline Missão & Objetivos & Equipe Editorial \\
\hline $\begin{array}{l}\text { A Revista Contabilidade \& Finanças } \\
\text { (RC\&F) tem como missão a } \\
\text { divulgação de produção científica } \\
\text { inédita e relevante na área de } \\
\text { Contabilidade, Controladoria, Atuária } \\
\text { e Finanças, produzida por professores, } \\
\text { pesquisadores, alunos e profissionais } \\
\text { do Brasil e do exterior, selecionada } \\
\text { exclusivamente com base em } \\
\text { qualidade e efetiva contribuição para } \\
\text { o desenvolvimento do conhecimento } \\
\text { científico nesses campos. }\end{array}$ & 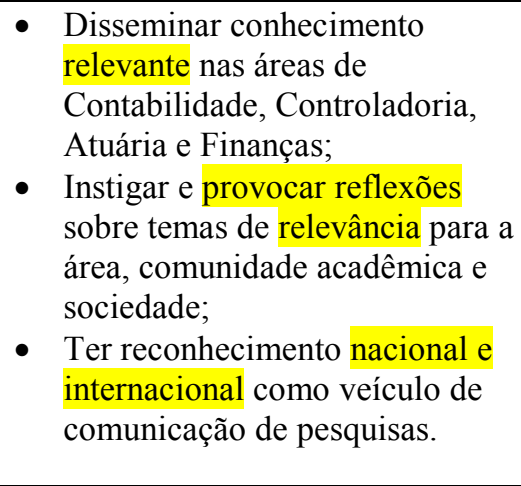 & $\begin{array}{l}\text { - } \text { Editor Chefe; } \\
\text { - } \text { Conselho Editorial; } \\
\text { - } \text { Editores Associados; } \\
\text { - } \text { Corpo Editorial Científico. }\end{array}$ \\
\hline
\end{tabular}

O discurso proferido na missão da RC\&F expressa interesse em publicar produção inédita e relevante, que traga efetiva contribuição para o desenvolvimento científico na área contábil, de autoria de "professores, pesquisadores, alunos e profissionais". Pelo expresso no texto, podemos compreender que o periódico tenciona por produções decorrentes de indivíduos que se enquadram tanto no contexto técnico ou quanto acadêmico, incluso que a 
descrição tem a intenção de mostrar a abertura que o periódico oferece a diferentes públicos, potenciais autores. Todavia, a tipologia utilizada para se referir aos potenciais autores do periódico evidencia o distanciamento entre os interessados na produção da área uma vez que os termos "professores" e "pesquisadores", "profissionais" são usados com intenções semânticas distintas. Concebe-se a ideia de um professor que não pode ser pesquisador, bem como de um professor e pesquisador que não podem ser um profissional técnico, o contrário é verdadeiro para ambos os casos. Além do evidente hiato existente quando se faz referência à academia e à sociedade, ainda que de maneira inconsciente, percebemos também que o texto oculta o termo técnico para se referir ao profissional que não possui vínculo com a academia - adicionamos o termo porque nos parece que essa seria a intenção do discurso.

Outro aspecto que merece atenção é a expressão “do Brasil e do exterior" para fazer referência aos potenciais autores do periódico. Como a possibilidade de estudos internacionais abordarem temáticas de interesse específico do Brasil, podemos compreender que o periódico se interessa também por assuntos de interesse global - este fato revela um dos elementos observados ao expressar o interesse por "produção inédita e relevante". Se por um lado pensamos que a abertura a produção internacional é uma tentativa de aproximação a realidades outras que podem favorecer ao aprendizado e ao amadurecimento das discussões, por outro, essa abertura requer uma atenção redobrada quando da seleção dos artigos para o processo de avaliação. Acreditamos que o estabelecimento do diálogo científico seja produtivo se artigos apresentarem discussões relativas a temáticas e problemas que, pelo menos, tangenciem aqueles enfrentados pela contabilidade de um país em desenvolvimento como o nosso. Este cuidado parece-nos manifesto quando no texto da missão surge a expressão "selecionada exclusivamente com base em qualidade e efetiva contribuição para o desenvolvimento do conhecimento científico ...”.

Ademais, entendemos que a qualificação "relevante" possui centralidade. Esse termo é retomado nos objetivos por meio da repetição do item lexical "relevante" e por meio de uma palavra do mesmo campo semântico "relevância". Podemos, inclusive, inferir que a missão da RC\&F se apropria do termo "relevância" como equivalente à expressão "efetiva contribuição" e a palavra "qualidade", visto que essas são critérios exclusivos e balizadores dos aceites concedidos por esse periódico. Porém, enquanto a expressão "efetiva contribuição" nos remete a ideia concreta de utilidade da pesquisa, a julgada "qualidade" não consegue alcançar o mesmo êxito em função da multiplicidade de sentidos que pode gerar - não há qualquer menção sobre a que vem dizer essa pesquisa de qualidade.

Cabe observar ainda que, embora os termos "relevante" e "relevância" apareçam em 
dois dos três objetivos, e a definição do que é "relevante", compete aos avaliadores do periódico. O que tem mais peso é "ser relevante", característica de difícil definição, inclusive porque essa relevância (que pode ser percebida pela ressonância da pesquisa, por exemplo) só se materializará de fato após tornar o artigo produzido de conhecimento público e não no momento da seleção. Assim, como todos os artigos publicados na RC\&F têm o atributo "relevância", há uma tendência de que os pesquisadores possam tomá-los como parâmetro para novas produções, estabelecendo um efeito "propagandístico". Como discutimos anteriormente na "História da Investigação", o discurso tanto é influenciado pelo contexto social quanto tem poder para influenciá-lo. Assim, os artigos publicados pela RC\&F têm poder para captar, modificar e propor realidade - neste caso, a replicação dos artigos é a materialização dessa influência discursiva.

Esse efeito "propagandístico" pode ser percebido pelo uso dos verbos divulgar e disseminar. Além da escolha desses dois verbos, há que se observar também a transformação da frase "Divulgação de produção científica relevante" para "Disseminar conhecimento relevante" desaparecendo o caráter inédito do conhecimento a ser divulgado. Ainda que se argumente que a palavra "inédita" está elíptica, o aparecimento do terceiro objetivo não relacionado diretamente à produção, e sim, relacionado à abrangência geográfica da disseminação pretendida é suficiente para amenizar tal argumento.

Apontando ao mesmo tempo para a divulgação e para a relevância, não é de se estranhar que vá se desencadear a elaboração de replicações, tendência que notamos, a princípio, em nossos alunos. Como "o mundo da pesquisa envolve a manipulação e o poder do mainstream" (Frezatti et al., 2009, p. 7), a nosso ver, as replicações são realizadas como estratégia para a aceitação e, conseguinte, publicação do artigo mantendo um perigoso ciclo de inércia e/ou atrofia do conhecimento científico gerado, fruto da produção do terceiro grupo de indivíduos (sem formação) a que nos referimos anteriormente. Outro aspecto que merece atenção é a expressão "reconhecimento nacional e internacional" citada no terceiro objetivo, de maneira a desalinhá-lo da discussão sobre produção de conhecimento, dado que respeito à abrangência geográfica pretendida - uma preocupação de alcançar status além das fronteiras do país. Isso nos leva a pensar que as temáticas serão escolhidas com a expectativa de atender também a um público estrangeiro, e podem trazer, por vezes, discussões de questionável "relevância" às organizações e a sociedade brasileira em geral.

Se considerarmos o que está expresso no escopo e linhas de pesquisa da RC\&F, os artigos submetidos a esse periódico científico devem observar o Escopo e Linhas de pesquisa de acordo com a Tabela 4: 
Tabela 4:

Escopo e linhas de pesquisa da $R C \& F$.

\begin{tabular}{|c|c|}
\hline Escopo & Linhas de pesquisa \\
\hline $\begin{array}{l}\text { A RC\&F publica artigos inéditos de desenvolvimento } \\
\text { teórico e trabalhos teórico-empíricos nas áreas } \\
\text { de Contabilidade, Controladoria, Atuária e Finanças. } \\
\text { Aceita trabalhos de diferentes paradigmas e metodologias, } \\
\text { desde que sejam consistentes e relevantes para o } \\
\text { desenvolvimento das áreas. Além de artigos, foco principal } \\
\text { do periódico, pública resenhas, comunicaçõe s, notas } \\
\text { bibliográficas, pensatas e documentos que possam contribuir } \\
\text { para a comunicação de novos conhecimentos para a } \\
\text { comunidade. }\end{array}$ & $\begin{array}{l}\text { - Controladoria e contabilidade gerencial; } \\
\text { - Contabilidade para usuários externos; } \\
\text { - Mercados: financeiro, de crédito e de capitais; } \\
\text { - Educação e pesquisa em contabilidade, } \\
\text { controladoria, atuária e finanças; } \\
\text { - Atuária; } \\
\text { - Temas emergentes em Contabilidade, Finanças } \\
\text { e Atuária. }\end{array}$ \\
\hline
\end{tabular}

Atentando-nos ao vocabulário utilizado para a descrição do escopo da revista RC\&F, temos na primeira frase o atributo "inéditos" fazendo alusão ao termo "artigos", em seguida, a conjunção aditiva "e" que une as expressões "artigo inéditos de desenvolvimento teórico" a expressão "trabalhos teórico-empíricos". Dito dessa forma, entendemos que os artigos precisam ser inéditos e teóricos, já os trabalhos requerem o atributo teórico-empírico, ainda que na prática a RC\&F considere o ineditismo como condição necessária para a publicação de artigo, o sentido da frase revela a descrença de que trabalhos que envolvem aspectos pragmáticos não podem ser inéditos. Além disso, há subjetividade acerca do formato dos trabalhos teórico-empíricos suscetíveis de apresentação, já que o termo "trabalhos" é generalista. Ratificamos essa interpretação quando na segunda frase do parágrafo nos deparamos com a expressão "aceita trabalhos de diferentes paradigmas e metodologias".

Outro fato que atem a nossa atenção é o uso da expressão "desde que sejam consistentes e relevantes para o desenvolvimento das áreas”. Para nós o vocábulo "consistentes" consegue delimitar sentido e refere-se à questão da cientificidade dos trabalhos. Já o vocábulo "relevantes" nos deixa mais uma vez diante de uma situação de subjetividade, vinculada ao processo de seleção dos trabalhos, e de forte impacto para a área de conhecimento - trata-se de um critério que determinará a essência do interesse científico das áreas de conhecimento contempladas pela revista (Contabilidade, Controladoria, Atuária e Finanças). $\mathrm{Na}$ última frase do parágrafo, temos que resenhas, comunicações, notas bibliográficas, pensatas e documentos podem vir a ser publicadas, desde que a RC\&F as compreenda que como aporte de "novos conhecimentos para a comunidade". O termo "novo" pertence ao mesmo campo semântico do termo "inéditos" utilizado na primeira frase do parágrafo do escopo. Enquanto na primeira frase ele se referia a "artigos", nessa última ele se refere a "conhecimentos" propiciados pelos outros tipos de trabalhos que também são aceitos pela revista. Entendemos, dessa maneira, que tanto os artigos considerados "foco principal do periódico", quanto àqueles outros trabalhos citados anteriormente devem ser originais. 
De acordo com a RC\&F (2015), este periódico publica (por ano) um artigo por autor seja esse artigo uma produção individual ou em grupo - em atenção às boas práticas de pesquisa. Segundo as normas desse periódico, quando a investigação trata sobre sistemas de mensuração, informação e apoio ao processo de planejamento e controle das instituições ela é classificada na linha, "controladoria e contabilidade gerencial". Caso a discussão seja sobre aspectos de identificação, mensuração e divulgação da informação contábil tem-se um estudo da linha "contabilidade para usuários externos". Se aborda aspectos conceituais e/ou empíricos de mercados, bem como sobre aplicação de recursos sob a ótica da performance empresarial passado e/ou projetada, vinculados à Contabilidade, o estudo é classificado na linha de "mercados: financeiro, de crédito e de capitais".

Por sua vez, quando o trabalho traz aspectos relacionados ao processo de ensinoaprendizagem e da pesquisa contábil o estudo pertence à linha de "educação e pesquisa em contabilidade, controladoria, atuária e finanças". Se a temática é sobre modelos, métodos, técnicas e instrumentos e construção de trabalhos científicos vinculados às Ciências Atuariais tem-se um estudo da linha "atuária".

De 2001 a 2015 a RC\&F publicou um total de 355 artigos distribuídos da seguinte maneira: 19\% referentes à "linha 1 - Controladoria e contabilidade gerencial"; $40 \%$ à "linha 2 - Contabilidade para usuários externos"; $25 \%$ à "linha 3 - Mercados: financeiro, de crédito e capitais"; $11 \%$ à "linha 4 - Educação e Pesquisa em contabilidade, controladoria, atuária e finanças"; 4\% à "linha 5 - Atuária" e 2\% classificados como "História da Contabilidade". Ressalta-se que a linha "História da Contabilidade" é específica de um número especial publicado em celebração dos 25 anos desse periódico, em 2014.

Consta no site da RC\&F (2015) a inserção de uma nova linha de pesquisa denominada “Temas emergentes em Contabilidade, Finanças e Atuária”, a qual abarca os denominados assuntos inovadores. Porém, até o último número de 2015 (revista v. 26, n. 69) não há artigos assim classificados, motivo pelo qual não consta da Figura 8. Percebemos uma prevalência/hegemonia dos artigos referentes à linha "Contabilidade para usuários externos" essa hegemonia no decorrer dos aproximados 15 anos nos inspirou a selecionar os artigos da mesma como corpus de análise no âmbito.

Ainda de acordo com as informações do site da RC\&F, o processo de avaliação dos artigos submetidos se dá por meio do sistema double blind review, ou seja, os trabalhos são encaminhados para análise sem identificação dos autores para avaliadores, cuja identificação também não é revelada. Ademais, os avaliadores podem ser escolhidos a partir de indicações dos auditores associados, todavia, é o Editor Chefe quem encaminha o convite para 
composição do grupo de pesquisadores da RC\&F, respeitadas as suas especificações. $\mathrm{O}$ template de avaliação abrange aspectos como: interesse do periódico (escopo), metodologia, constructo teórico, inovação, relevância, impacto, profundidade clareza, referencial, acessibilidade aos leitores, dentre outros.

\subsection{Equipe Editorial da Revista Contabilidade \& Finanças}

A Equipe Editorial da RC\&F é constituída pelo Editor-chefe, pelo Conselho Editorial, pelos Editores Associados e pelo Corpo Editorial Científico. Essa estrutura é apresentada no site da revista e está em conformidade com a ABNT (2003) e o Manual Anpad (2010). Para Trzesniak (2009), uma Equipe Editorial que possui de 20 a 35 membros (conselheiros ou colegiado) e entre dois e quatro editores associados consegue atender a um contingente de 100 submissões deferidas anualmente. De acordo com o site da RC\&F, em 2014 foram deferidas 50 submissões, e a equipe editorial era composta por 34 membros - número superior àquele considerado como ideal pela literatura.

Conforme Figura 7, a seguir, a RC\&F conta atualmente com uma Equipe Editorial constituída por 32 conselheiros, dos quais seis são Editores Associados. Nota-se que 29\% dos membros dessa Equipe Editorial são exclusivos do Conselho Editorial e 47\% exclusivos do Corpo Editorial Científico. Estes percentuais, atrelados à discussão apresentada na seção anterior, nos levam a construir o seguinte raciocínio: como o Conselho Editorial trabalha sempre em equipe - suas decisões são representativas de uma deliberação do grupo - e, contrariamente, o Corpo Editorial Científico trabalha individualmente quando consultado, ambos os grupos representam minoria em termos de influência ideológica. Isto acontece porque em quaisquer das situações entendemos que os membros "exclusivos" de cada um desses grupos têm menos força participativa: os $29 \%$, porque têm participação diluída; e os $47 \%$, por ter participação esporádica.

Por esse motivo, não faremos maiores comentários sobre o perfil desses conselheiros. Buscamos compreender o perfil e as relações institucionais estabelecidas pelos conselheiros que guardam maior força participativa e, por conseguinte, influência ideológica no periódico. Segundo Koch (1999, p. 19), “como ser dotado de razão e vontade, o homem, constantemente avalia, julga, critica, isto é, forma juízo de valor" e, para nós, isso influencia direta e/ou indiretamente na produção científica divulgada, já que a ideologia dominante é constituída pela opinião desse grupo. 


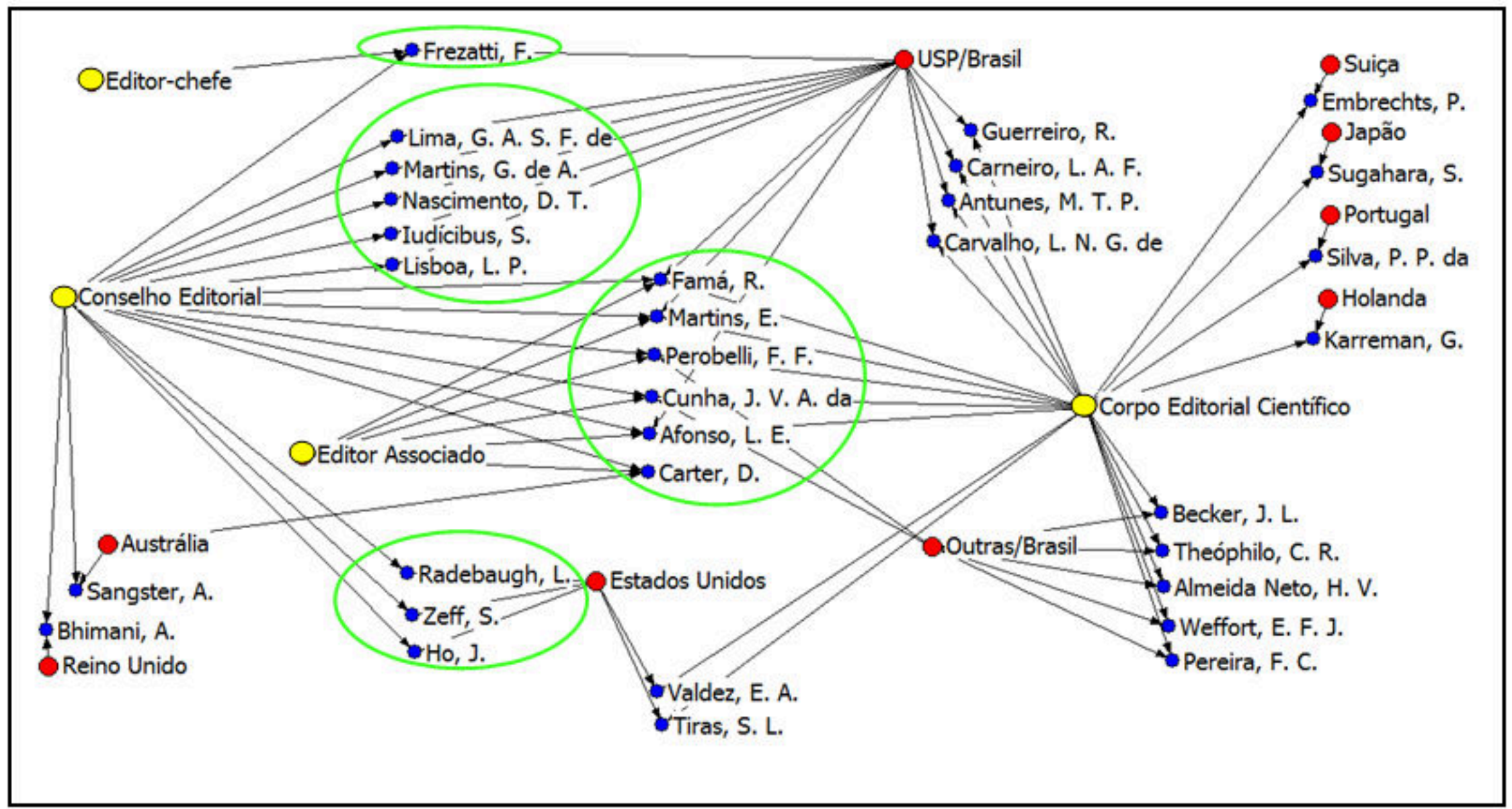

Figura 7. Equipe Editorial da RC\&F/2015: pesquisadores, suas funções e país da IES de vínculo. 
De acordo com a Figura 7, notamos que aproximadamente $22 \%$ do colegiado que constitui a Equipe Editorial da RC\&F exercem duas ou mais funções. Os pesquisadores Famá, R.; Martins, E.; Perobelli, F. F.; Cunha, J. V. A. da; Afonso, L. E. e Carter, D. se destacam no contexto por fazerem parte de núcleo que atua diretamente sobre a Política Editorial e sobre a produção científica em avaliação exercendo as funções de Conselho Editorial e Editor Associado, respectivamente. Isso nos revela a forte ingerência (poder de influência ideológica) que os mesmos têm sobre a revista dadas as suas competências - seja no tocante à política editorial, seja na produção propriamente dita ou em situações específicas, quando alguns desses atuam como Corpo Científico. Destaca-se, porém, que essa influência não é hierarquicamente superior ao poder de decisão decorrente da função de Editor-chefe do periódico, exercida por Frezatti, F.

Considerando os países de origem das IES a que se vinculam os membros da Equipe Editorial da RC\&F, demonstrados também na Figura 7, chama-nos à atenção o fato que dentre 17 membros que compõem o Conselho Editorial há uma prevalência de brasileiros oriundos da USP (53\%) e de estrangeiros, vinculados a instituições sediadas nos Estados Unidos (18\%). Isto nos permite afirmar que as Políticas Editoriais desse periódico tendem a ser representativas destes centros, ou seja, da forma de conceber ciência, ou seja, na ontologia firmada por meio das linhas de pesquisa e, consequentes temáticas, teorias, metodologias, maneira de expor reflexões e críticas, dentre outros aspectos.

A prevalência de pesquisadores da USP no Conselho Editorial da RC\&F não nos causa estranheza, afinal este periódico é vinculado ao Departamento de Contabilidade e Atuária da FEA/USP, tendo o chefe desse departamento como seu presidente - atualmente o Prof. Dr. Gerlando Augusto Sampaio Franco de Lima. Assim, os princípios essenciais do periódico (missão, objetivos, público-alvo...), a sua estrutura e a sua linha editorial, bem como suas diretrizes de submissão e os aspectos éticos observados, são elaborados por esse conselho atribuindo ao periódico uma "personalidade científica”. Trzesniak (2009) considera que vínculos institucionais estabelecidos por um periódico científico podem assegurar a continuidade das atividades que este realiza - fator de extrema importância para consolidar os elos e estreitar a comunicação entre academia e sociedade.

Por sua vez, os Editores Associados da RC\&F possuem graduação nas áreas de Contabilidade, Administração e Economia, áreas afins, além de Direito e Engenharia da Produção. Esses membros se dedicam exclusivamente a uma linha de pesquisa, e de acordo com o Curriculum Vitae (CV) de cada um, possuem experiência acadêmica e técnica nessas áreas. No que se refere à formação acadêmica desses pesquisadores, percebemos que a USP, a 
Univerdidade de Illinois e a Harvard Business School são instituições citadas em pelo menos dois CVs, seja em cursos de graduação, pós-doutorado ou formação complementar.

É relevante destacar que, tanto os Editores Associados quanto o Editor-chefe (com atribuições técnicas e científicas) participam ou participaram de entidades de destaque e ingerência no cenário nacional da contabilidade (Figura 8) - em alguns casos, essa participação se deu pelo exercício de funções como presidência e diretoria. No âmbito nacional, são exemplos de entidade a Comissão de Valores Mobiliários (CVM), Conselho Nacional de Desenvolvimento Científico e Tecnológico (CNPq), Coordenação de Aperfeiçoamento de Pessoal de Nível Superior (CAPES), Conselho Federal de Contabilidade (CFC), Sociedade Brasileira de Finanças (SBFin), Banco Central do Brasil (Bacen), Comitê de Pronunciamentos Contábeis (CPC), Instituto dos Auditores Independentes do Brasil (IBRACON), Associação Nacional dos Executivos de Finanças, Administração e Contabilidade (ANEFAC), Associação Nacional de Pós-Graduação e Pesquisa em Administração (ANPAD), Fundação Instituto de Pesquisas Contábeis Atuariais e Financeiras (FIPECAFI) dentre outros(as). No âmbito internacional temos a American Accounting Association (AAA), European Accounting Association (EAA), International Association for Accounting Education and Research (IAAER) e a International Actuarial Association (IAA).

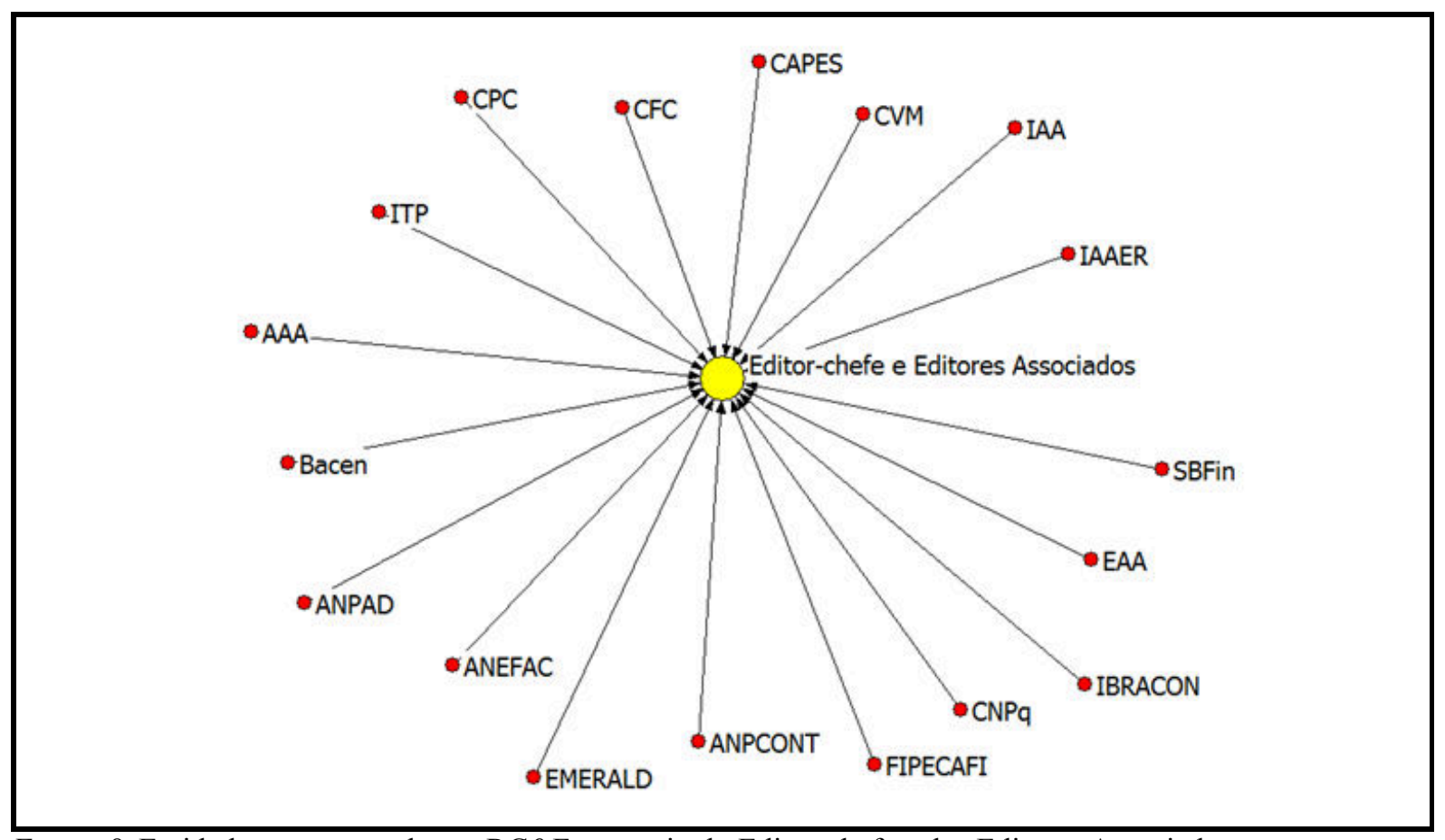

Figura 8. Entidades representadas na RC\&F por meio do Editor-chefe e dos Editores Associados.

Além de formativa, a experiência e relações dos conselheiros junto a entidades ligadas à educação, à pesquisa e a atividade técnica promovem a integração academia-sociedade, 
além da oportunidade de estabelecer diálogos entre pesquisadores brasileiros e pesquisadores internacionais. Desta forma, consideramos que essas instituições guardam significativa influência na maneira como os conselheiros da RC\&F percebem a potencial utilidade, a relevância e as contribuições dos artigos científicos submetidos. Trzesniak (2009) já expunha quão positivo é esse aspecto para a continuidade do periódico - a CAPES, o CNPq e FIPECAFI, por exemplo, são patrocinadores da RC\&F.

No que se refere aos Consultores Ad Hoc, temos uma pulverização de 75\% deles em diferentes Instituições de Ensino Superior (IES) brasileiras - não há incidência superior a três avaliadores numa mesma instituição - os $23 \%$ restantes são vinculados à FEA/USP e $2 \%$ dos Consultores Ad Hoc da RC\&F a instituições portuguesas. Ao analisar a distribuição desses consultores nas IES brasileiras, percebemos uma concentração significativa de pesquisadores vinculados àquelas da Região Sudeste (72\%), sendo os $28 \%$ restantes distribuídos da seguinte forma: Nordeste (12\%); Sul (9\%) e Centro-Oeste (7\%). Entendemos que há uma predominância da forma de conceber ciência que se vincula tanto à instituição quanto à região a que o periódico pertence. Já em relação à graduação cursada pelos avaliadores desse periódico, temos a distribuição conforme Figura 9.

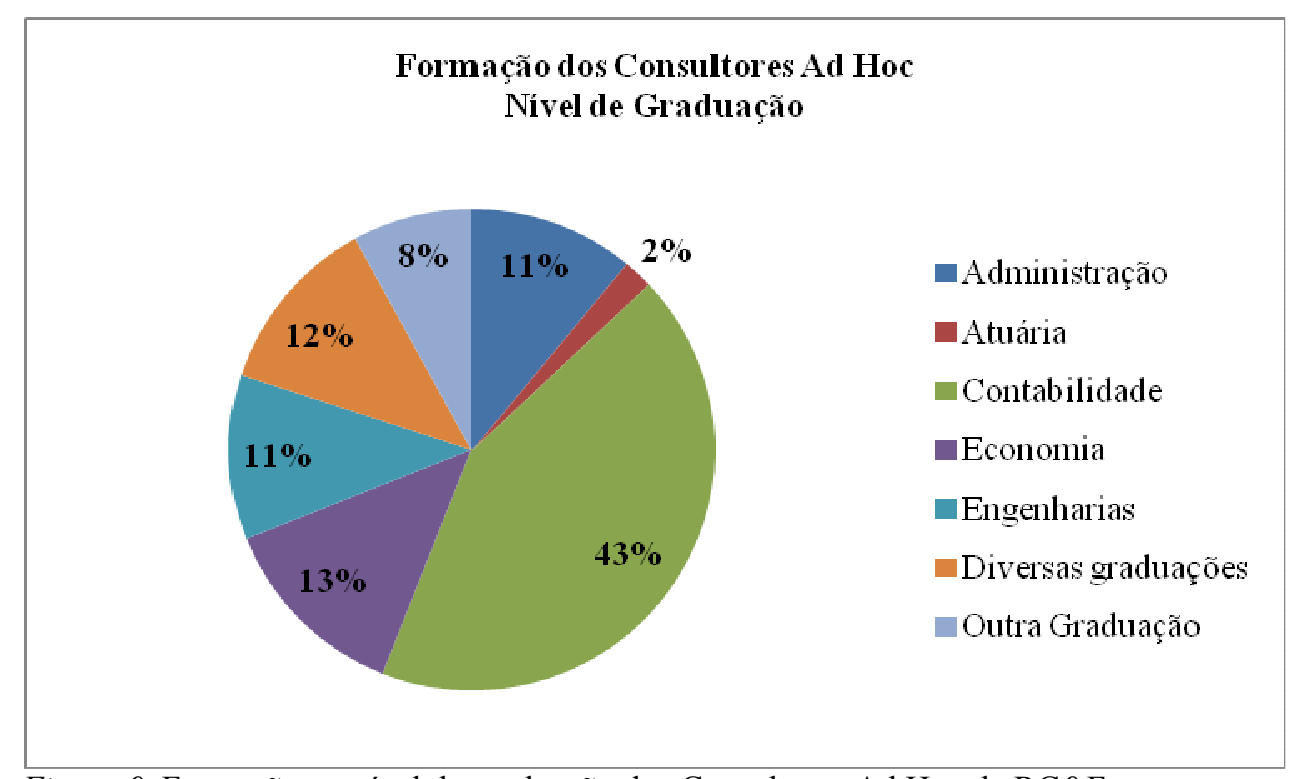

Figura 9. Formação no nível de graduação dos Consultores Ad Hoc da RC\&F.

Conforme CVs dos avaliadores (Consultores Ad Hoc da RC\&F), 43\% são graduados em Contabilidade, 13\% em Economia, 11\% em uma Engenharia (Civil, Mecânica, Química Elétrica ou de Produção), 2\% em Atuária, 12\% possuem mais de uma graduação Administração e Contabilidade; Economia, Contabilidade e Direito; Contabilidade e Atuária; Economia e Engenharia da Produção; Contabilidade e Letras, Economia e Contabilidade; 
Processamento de Dados e Contabilidade; além de Contabilidade, Administração, Economia e Direito. 8\% possuem uma graduação em outras áreas - Direito ou Ciência da Computação ou Matemática ou Pedagogia (Figura 9).

No que se refere ao maior nível de formação, temos que $68 \%$ dos avaliadores da RC\&F são oriundos dos Programas da FEA/USP, e que $90 \%$ destes são doutores em Contabilidade - Programa de doutorado do departamento ao qual a RC\&F é vinculada. Este aspecto pode ser evidenciado ao observarmos a densidade da rede que liga os pontos "FEA/USP" e "Contabilidade" evidenciados na Figura 10, a seguir: 


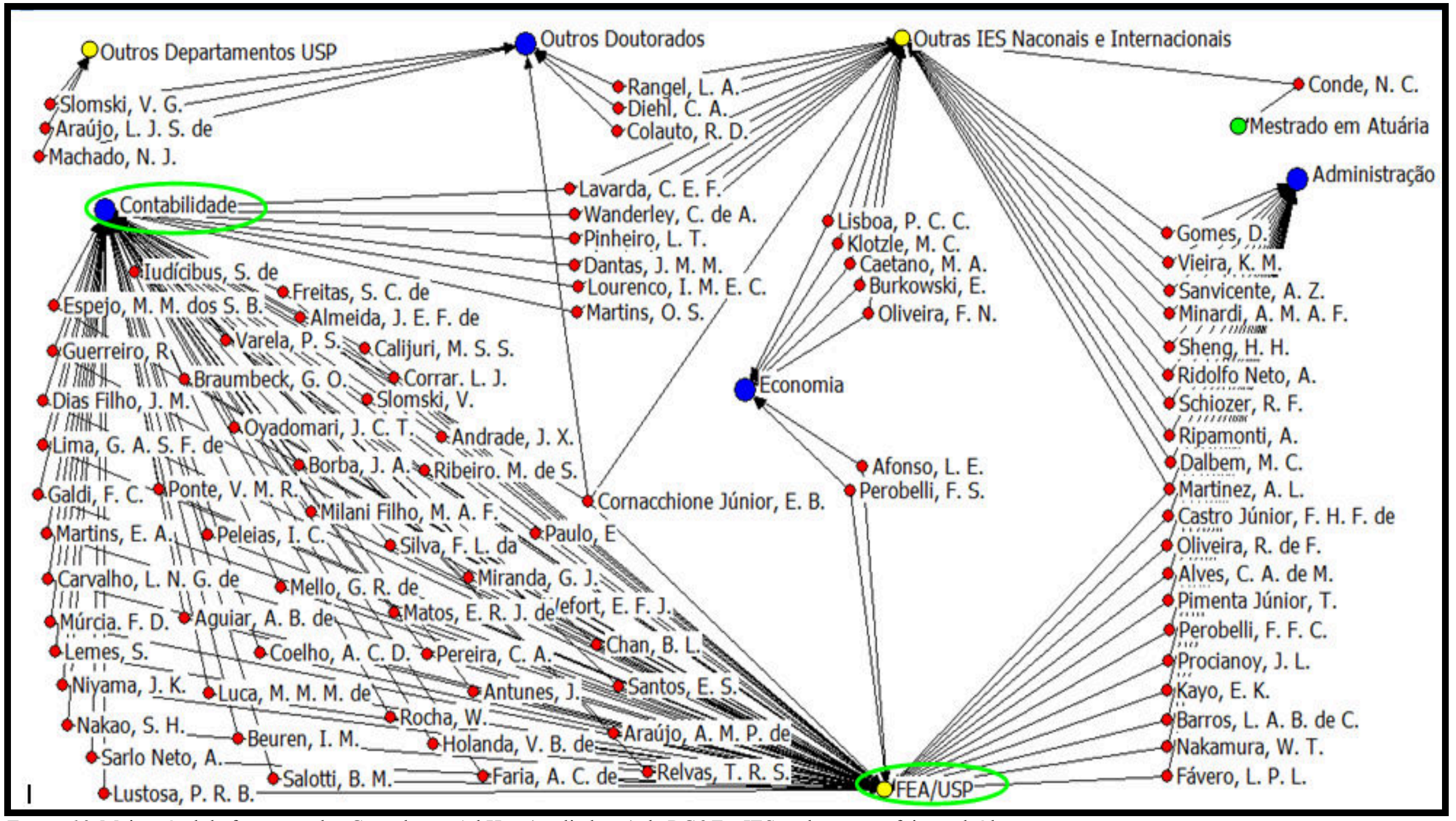

Figura 10. Maior nível de formação dos Consultores Ad Hoc (avaliadores) da RC\&F e IES onde o curso foi concluído. 
$22 \%$ dos avaliadores da RC\&F possuem doutorado em Administração, dos quais 55\% são doutores egressos da FEA/USP. Chama-nos à atenção o fato de haver uma predominância de avaliadores egressos dos cursos de doutorado oferecidos pela USP; são $73 \%$ do total de avaliadores do periódico. Uma das justificativas para a predominância da FEA/USP está no fato de que seu Programa de Doutorado em Contabilidade foi o primeiro do Brasil e, desde sua implantação, vem “... influenciando de maneira decisiva a pesquisa contábil brasileira, pois a maioria absoluta dos doutores em Ciências Contábeis brasileiros é egressa desse Programa" (Peleias, Silva, Segreti, \& Chirotto, 2007). Vale destacar que, durante mais de duas décadas, o Programa de Doutorado em Contabilidade da FEA/USP foi o único do Brasil. Além das áreas afins (Contabilidade, Administração e Economia), alguns dos avaliadores da RC\&F possuem doutorado em Engenharia da Produção, Engenharia Elétrica, Políticas Públicas, Estratégias e Desenvolvimento, Educação e Recursos Humanos.

\subsection{Fontes referenciais da $\mathrm{RC} \& \mathrm{~F}$ nos últimos seis anos}

A fim de conhecer detalhadamente os textos que têm alimentado a produção do conhecimento na área contábil, o que Fairclough (2008) apresenta como intertextualidade manifesta, examinamos 4.690 trabalhos referenciados nos artigos publicados pela RC\&F durante os últimos seis anos. Verificamos a autoria, o tipo de material referenciado, a fonte do material, o país de origem, o idioma e o número de citações de cada referência.

Quando nos referimos à autoria, buscamos conhecer os autores mais citados pela revista, evidenciando a prevalência de determinados nomes no contexto do periódico. Em relação ao tipo de material, classificamos como artigo, livro, instrumentos normativos, texto informativo, lei, dissertação, documento, imagem, manuscrito, relatório, tese ou working paper. Essa classificação contém alguns agrupamentos que fizemos no sentido de imprimir maior eficiência à análise que realizamos; consideramos irrelevante ao nosso objetivo um número excessivo de especificações para os materiais. Tais agrupamentos foram consolidados como: artigos - aqueles publicados em revista científica ou congressos/encontros; livro tanto o material na íntegra quanto os capítulos citados; instrumentos normativos - resolução, circular, instrução normativa ou norma, portaria e regulamento; texto informativo - texto de jornal impresso ou online, boletim, comunicado, declaração, nota e pronunciamento; e lei - a lei propriamente dita, decreto, emenda e projeto de lei.

A Tabela 5, a seguir, apresenta informações referentes aos autores mais citados nas 
publicações da RC\&F no período de 2010 a 2015 - selecionamos os autores que aparecem pelo menos em cinco referências dentre as 4.690 examinadas.

Tabela 5:

Informações sobre as referências mais citadas nos seis últimos anos de publicação da RC\&F.

\begin{tabular}{|c|c|c|c|c|c|c|c|c|}
\hline Ranking & Autores & $\begin{array}{l}\quad \mathrm{N}^{\mathrm{o}} \text { de } \\
\text { citações nas } \\
\text { referências }\end{array}$ & $\begin{array}{l}\text { Tipo de } \\
\text { material }\end{array}$ & $\begin{array}{l}\text { Fonte/ } \\
\text { origem }\end{array}$ & $\begin{array}{c}\text { Título/ } \\
\text { Denominação }\end{array}$ & $\begin{array}{l}\text { País de } \\
\text { origem }\end{array}$ & Idioma & $\begin{array}{c}\text { No de } \\
\text { citações } \\
\text { Google } \\
\text { Acadêmico }\end{array}$ \\
\hline $1^{\underline{o}}$ & $\begin{array}{l}\text { Jensen, M. } \\
\text { C., \& } \\
\text { Meckling, } \\
\text { W. H. } \\
(1976)\end{array}$ & 19 & Artigo & $\begin{array}{l}\text { Periódico } \\
\text { Online }\end{array}$ & $\begin{array}{l}\text { Journal of } \\
\text { Financial } \\
\text { Economics }\end{array}$ & EUA & Inglês & 54.704 \\
\hline $2^{\underline{o}}$ & $\begin{array}{l}\text { Basu, S. } \\
\text { (1997) }\end{array}$ & 7 & Artigo & $\begin{array}{l}\text { Periódico } \\
\text { Online }\end{array}$ & $\begin{array}{c}\text { Journal of } \\
\text { Accounting and } \\
\text { Economics }\end{array}$ & EUA & Inglês & 3.232 \\
\hline $2^{\underline{o}}$ & $\begin{array}{l}\text { Brooks, C. } \\
(2002)\end{array}$ & 7 & Livro & Impresso & $\begin{array}{l}\text { Introductory } \\
\text { econometrics } \\
\text { for finance }\end{array}$ & $\begin{array}{l}\text { Reino } \\
\text { Unido }\end{array}$ & Inglês & 2.655 \\
\hline $3^{-}$ & $\begin{array}{l}\text { Baltagi, B. } \\
(2005)\end{array}$ & 6 & Livro & Impresso & $\begin{array}{l}\text { Econometric } \\
\text { analysis of } \\
\text { panel data }\end{array}$ & $\begin{array}{l}\text { Reino } \\
\text { Unido }\end{array}$ & Inglês & 12.649 \\
\hline $3^{\mathrm{o}}$ & $\begin{array}{l}\text { SHARPE, } \\
\text { W. (1964) }\end{array}$ & 6 & Artigo & $\begin{array}{l}\text { Periódico } \\
\text { Online }\end{array}$ & $\begin{array}{c}\text { The Journal of } \\
\text { Finance }\end{array}$ & EUA & Inglês & 16.788 \\
\hline $4^{\mathrm{o}}$ & $\begin{array}{l}\text { Bardin, L. } \\
\text { (1977) }\end{array}$ & 5 & Livro & Impresso & $\begin{array}{l}\text { Análise de } \\
\text { conteúdo }\end{array}$ & Portugal & $\begin{array}{c}\text { Portuguê } \\
\text { s }\end{array}$ & 35.732 \\
\hline $4^{\circ}$ & $\begin{array}{l}\text { Beaver, } \\
\text { W. et al. } \\
(1970)\end{array}$ & 5 & Artigo & $\begin{array}{l}\text { Periódico } \\
\text { Online }\end{array}$ & $\begin{array}{c}\text { The Accounting } \\
\text { Review }\end{array}$ & EUA & Inglês & 1.192 \\
\hline $4^{\mathrm{o}}$ & $\begin{array}{l}\text { Shleifer, } \\
\text { A., \& } \\
\text { Vishny, R. } \\
\text { (1997) }\end{array}$ & 5 & Artigo & $\begin{array}{l}\text { Periódico } \\
\text { Online }\end{array}$ & $\begin{array}{c}\text { The Journal of } \\
\text { Finance } \\
\text { Financial }\end{array}$ & EUA & Inglês & 14.454 \\
\hline $4^{\circ}$ & $\begin{array}{l}\text { Scott, W. } \\
\text { R. }(2003)\end{array}$ & 5 & Livro & Impresso & $\begin{array}{l}\text { Accounting } \\
\text { Theory }\end{array}$ & Canadá & Inglês & 1.867 \\
\hline $5^{-0}$ & $\begin{array}{l}\text { Scott, W. } \\
\text { R. }(2001)\end{array}$ & 4 & Livro & Impresso & $\begin{array}{c}\text { Institutions and } \\
\text { organizations }\end{array}$ & EUA & Inglês & 25.416 \\
\hline $5^{\mathrm{o}}$ & $\begin{array}{l}\text { Barth, M. } \\
\text { E., } \\
\text { Landsman } \\
\text {, W. R., \& } \\
\text { Lang, M. } \\
\text { H. (2008) }\end{array}$ & 4 & Artigo & $\begin{array}{l}\text { Periódico } \\
\text { Online }\end{array}$ & $\begin{array}{l}\text { Journal of } \\
\text { Accounting } \\
\text { Research }\end{array}$ & EUA & Inglês & 1.698 \\
\hline
\end{tabular}

Podemos observar uma significativa pulverização em relação às fontes referenciais, pois a maior concentração evidenciada é de 19 menções do trabalho publicado pelos autores Jensen, M. C. \& Meckling, W. H. (1976); chamou-nos à atenção o fato de que o número de menções nas referências analisadas no período não chega a $1 \%$ do total de referências que foram listadas no período (4.690 referências). Trata-se de um artigo seminal publicado na revista holandesa Journal of Financial Economics que tem por título Theory of the Firm: 
Managerial Behavior, Agency Costs and Ownership Structure. Podemos perceber que, de acordo com o número de citações no Google Acadêmico, este é um texto relevante para as discussões que envolvem a temática explorada. O segundo lugar é ocupado por dois autores referenciados 7 vezes no período que são: Basu, S. (1997) e Brooks, C. (2002). Basu, S. (1997) foi referenciado pelo trabalho The conservatism principle and the asymmetric timeliness of earnings; trata-se de um artigo publicado no periódico estadunidense Journal of Accounting and Economics, o qual foi referenciado em 7 artigos no período analisado. Brooks, C. (2002) foi referenciado pela autoria do livro Introductory econometrics for finance, publicado em inglês no Reino Unido. Notamos que dentre os três referenciados da RC\&F no período analisado (2010-2015), equivalendo ao primeiro e segundo lugares, dois publicaram dois artigos e um livro - os artigos estão publicados em inglês (EUA) e o primeiro livro que aparece na lista de mais citado não trata de temática da área contábil, mas de econometria para finanças.

Considerando o ranking, as cinco primeiras posições da lista de autores mais citados (Tabela 5) nos revelam aspectos importantes: não há qualquer referência em português do Brasil - o único material que está no idioma português foi publicado em Portugal - os países de origem dos textos são EUA, Reino Unido, Portugal e Canadá. No ranking da Tabela 5 temos cinco livros: dois de econometria e um de análise de conteúdo, ambos os materiais são vinculados às técnicas empregadas nas análises das investigações ( $2^{\circ}, 3^{\circ}$ e $4^{\circ}$ no ranking). Os outros dois são: um de teoria da contabilidade, publicado no Canadá ( $4^{\underline{0}}$ lugar) e o outro trata sobre instituições e organizações, publicado nos EUA ( $5^{\circ}$ lugar). Destaca-se que nenhum dos materiais possui menos de 1.000 citações no Google Acadêmico, o mais citado tem 54.704 e o menos citado, 1.192 citações (até 20/12/2015 - data de fechamento da pesquisa).

A Tabela 6, a seguir, apresenta as distribuições das fontes referenciais por país e idioma. Por meio dela podemos notar que o idioma predominante dos textos é o inglês, que equivale a $68,04 \%$ das fontes referenciadas, seguido do idioma português $31,32 \%$ das fontes referenciadas. O espanhol, francês, alemão e o turco também aparecem como idiomas das fontes referenciadas, porém de maneira inexpressiva quando comparada ao inglês e ao português.

Em relação aos países de que são originados os textos, temos: Brasil, EUA, Reino Unido e Holanda com, respectivamente, $30,92 \% ; 30,55 \% ; 23,56 \%$ e $9,47 \%$ do total das fontes referenciadas. Se considerarmos apenas as fontes internacionais, temos que elas representam, juntas, $61,58 \%$ do total das referências no período estudado. 
Tabela 6: Distribuição das fontes por país e idioma

\begin{tabular}{|c|c|c|c|c|c|c|c|c|c|c|c|c|c|c|}
\hline País & Id. Alemão & $\%$ & Id. Espanhol & $\%$ & Id. Francês & $\%$ & Id. Inglês & $\%$ & Id.Português & $\%$ & Id. Turco & $\%$ & Total & $\%$ \\
\hline África do Sul & 0 & 0,00 & 0 & 0,00 & 0 & 0,00 & 2 & 100,00 & 0 & 0,00 & 0 & 0,00 & 2 & 0,04 \\
\hline Alemanha & 2 & 5,41 & 0 & 0,00 & 0 & 0,00 & 35 & 94,59 & 0 & 0,00 & 0 & 0,00 & 37 & 0,79 \\
\hline Argentina & 0 & 0,00 & 2 & 100,00 & 0 & 0,00 & 0 & 3,00 & 0 & 0,00 & 0 & 0,00 & 2 & 0,04 \\
\hline Austrália & 0 & 0,00 & 0 & 0,00 & 0 & 0,00 & 28 & 100,00 & 0 & 0,00 & 0 & 0,00 & 28 & 0,60 \\
\hline Bélgica & 0 & 0,00 & 0 & 0,00 & 0 & 0,00 & 6 & 100,00 & 0 & 0,00 & 0 & 0,00 & 6 & 0,13 \\
\hline Brasil & 0 & 0,00 & 1 & 0,07 & 0 & 0,00 & 18 & 1,24 & 1431 & 98,69 & 0 & 0,00 & 1450 & 30,92 \\
\hline Canadá & 0 & 0,00 & 1 & 2,70 & 0 & 0,00 & 35 & 94,59 & 1 & 2,70 & 0 & 0,00 & 37 & 0,79 \\
\hline China & 0 & 0,00 & 0 & 0,00 & 0 & 0,00 & 12 & 100,00 & 0 & 0,00 & 0 & 0,00 & 12 & 0,26 \\
\hline Colômbia & 0 & 0,00 & 1 & 100,00 & 0 & 0,00 & 0 & 0,00 & 0 & 0,00 & 0 & 0,00 & 1 & 0,02 \\
\hline Croácia & 0 & 0,00 & 0 & 0,00 & 0 & 0,00 & 1 & 100,00 & 0 & 0,00 & 0 & 0,00 & 1 & 0,02 \\
\hline Espanha & 0 & 0,00 & 17 & 70,83 & 0 & 0,00 & 6 & 25,00 & 1 & 4,17 & 0 & 0,00 & 24 & 0,51 \\
\hline EUA & 0 & 0,00 & 0 & 0,00 & 0 & 0,00 & 1421 & 99,16 & 12 & 0,84 & 0 & 0,00 & 1433 & 30,55 \\
\hline Filipinas & 0 & 0,00 & 0 & 0,00 & 0 & 0,00 & 1 & 100,00 & 0 & 0,00 & 0 & 0,00 & 1 & 0,02 \\
\hline Finlândia & 0 & 0,00 & 0 & 0,00 & 0 & 0,00 & 3 & 100,00 & 0 & 0,00 & 0 & 0,00 & 3 & 0,06 \\
\hline França & 0 & 0,00 & 0 & 0,00 & 4 & 16,00 & 21 & 84,00 & 0 & 0,00 & 0 & 0,00 & 25 & 0,53 \\
\hline Grécia & 0 & 0,00 & 0 & 0,00 & 0 & 0,00 & 3 & 100,00 & 0 & 0,00 & 0 & 0,00 & 3 & 0,06 \\
\hline Holanda & 0 & 0,00 & 0 & 0,00 & 0 & 0,00 & 442 & 99,55 & 2 & 0,45 & 0 & 0,00 & 444 & 9,47 \\
\hline Hungria & 0 & 0,00 & 0 & 0,00 & 0 & 0,00 & 1 & 100,00 & 0 & 0,00 & 0 & 0,00 & 1 & 0,02 \\
\hline Índia & 0 & 0,00 & 0 & 0,00 & 0 & 0,00 & 2 & 100,00 & 0 & 0,00 & 0 & 0,00 & 2 & 0,04 \\
\hline Irlanda & 0 & 0,00 & 0 & 0,00 & 0 & 0,00 & 1 & 100,00 & 0 & 0,00 & 0 & 0,00 & 1 & 0,02 \\
\hline Itália & 0 & 0,00 & 0 & 0,00 & 0 & 0,00 & 4 & 100,00 & 0 & 0,00 & 0 & 0,00 & 4 & 0,09 \\
\hline Japão & 0 & 0,00 & 0 & 0,00 & 0 & 0,00 & 6 & 100,00 & 0 & 0,00 & 0 & 0,00 & 6 & 0,13 \\
\hline Luxemburgo & 0 & 0,00 & 0 & 0,00 & 0 & 0,00 & 1 & 100,00 & 0 & 0,00 & 0 & 0,00 & 1 & 0,02 \\
\hline Malásia & 0 & 0,00 & 0 & 0,00 & 0 & 0,00 & 1 & 100,00 & 0 & 0,00 & 0 & 0,00 & 1 & 0,02 \\
\hline Nova Zelândia & 0 & 0,00 & 0 & 0,00 & 0 & 0,00 & 4 & 100,00 & 0 & 0,00 & 0 & 0,00 & 4 & 0,09 \\
\hline Peru & 0 & 0,00 & 0 & 0,00 & 0 & 0,00 & 0 & 0,00 & 1 & 100,00 & 0 & 0,00 & 1 & 0,02 \\
\hline Portugal & 0 & 0,00 & 0 & 0,00 & 0 & 0,00 & 1 & 5,88 & 16 & 94,12 & 0 & 0,00 & 17 & 0,36 \\
\hline Reino Unido & 0 & 0,00 & 0 & 0,00 & 0 & 0,00 & 1101 & 99,64 & 4 & 0,36 & 0 & 0,00 & 1105 & 23,56 \\
\hline República Checa & 0 & 0,00 & 0 & 0,00 & 0 & 0,00 & 1 & 100,00 & 0 & 0,00 & 0 & 0,00 & 1 & 0,02 \\
\hline R. Dominicana & 0 & 0,00 & 0 & 0,00 & 0 & 0,00 & 0 & 0,00 & 1 & 100,00 & 0 & 0,00 & 1 & 0,02 \\
\hline Romênia & 0 & 0,00 & 0 & 0,00 & 0 & 0,00 & 5 & 100,00 & 0 & 0,00 & 0 & 0,00 & 5 & 0,11 \\
\hline Singapura & 0 & 0,00 & 0 & 0,00 & 0 & 0,00 & 3 & 100,00 & 0 & 0,00 & 0 & 0,00 & 3 & 0,06 \\
\hline Suécia & 0 & 0,00 & 0 & 0,00 & 0 & 0,00 & 6 & 100,00 & 0 & 0,00 & 0 & 0,00 & 6 & 0,13 \\
\hline Suíça & 0 & 0,00 & 0 & 0,00 & 0 & 0,00 & 14 & 100,00 & 0 & 0,00 & 0 & 0,00 & 14 & 0,30 \\
\hline Taiwan & 0 & 0,00 & 0 & 0,00 & 0 & 0,00 & 1 & 100,00 & 0 & 0,00 & 0 & 0,00 & 1 & 0,02 \\
\hline Turquia & 0 & 0,00 & 0 & 0,00 & 0 & 0,00 & 1 & 50,00 & 0 & 0,00 & 1 & 50,00 & 2 & 0,04 \\
\hline Venezuela & 0 & 0,00 & 1 & 100,00 & 0 & 0,00 & 0 & 0,00 & 0 & 0,00 & 0 & 0,00 & 1 & 0,02 \\
\hline SD & 0 & 0,00 & 0 & 0,00 & 0 & 0,00 & 4 & 100,00 & 0 & 0,00 & 0 & 0,00 & 4 & 0,09 \\
\hline Total & 2 & 0 & 23 & 0,49 & 4 & 0,09 & 3.191 & 68,04 & 1.469 & 31,32 & 1 & 0 & 4.690 & 100,00 \\
\hline
\end{tabular}


Conforme vimos anteriormente, há uma concentração de fontes referenciais de quatro países. Todavia, vale destacar que há fontes referenciais de 37 países: África do Sul, Alemanha, Argentina, Austrália, Bélgica, Brasil, Canadá, China, Colômbia, Croácia, Espanha, EUA, Filipinas, Finlândia, França, Grécia, Holanda, Hungria, Índia, Irlanda, Itália, Japão, Luxemburgo, Malásia, Nova Zelândia, Peru, Portugal, Reino Unido, República Checa, R. Dominicana, Romênia, Singapura, Suécia, Suíça, Taiwan, Turquia e Venezuela. Quatro dentre as 4.690 fontes referenciadas ficaram Sem Denominação (SD) - não conseguimos encontrar o país no qual o material foi publicado.

A Tabela 7 evidencia o tipo e a origem do material referenciado. As minúcias sobre a classificação destes materiais já foram comentadas anteriormente, e no que diz respeito à origem do material, nos ativemos a examinar se a fonte é de material online ou impresso. Vejamos:

Tabela 7:

Tipo e origem do material referenciado

\begin{tabular}{|c|c|c|}
\hline Tipo de material & Total & $\%$ \\
\hline Artigo & 3125 & 66,63 \\
\hline Anais Online & 146 & 3,11 \\
\hline Impresso & 9 & 0,19 \\
\hline Outros online & 19 & 0,41 \\
\hline Periódico Online & 2951 & 62,92 \\
\hline Dissertação & 79 & 1,68 \\
\hline Impresso & 6 & 0,13 \\
\hline Online & 73 & 1,56 \\
\hline Documento & 18 & 0,38 \\
\hline Impresso & 3 & 0,06 \\
\hline Online & 15 & 0,32 \\
\hline Imagem & 1 & 0,02 \\
\hline Online & 1 & 0,02 \\
\hline Instrumentos Normativos Diversos & 95 & 2,03 \\
\hline Impresso & 1 & 0,02 \\
\hline Online & 94 & 2,00 \\
\hline Lei & 41 & 0,87 \\
\hline Online & 41 & 0,87 \\
\hline Livro & 745 & 15,88 \\
\hline Impresso & 673 & 14,35 \\
\hline Online & 72 & 1,54 \\
\hline Manuscrito & 2 & 0,04 \\
\hline Manuscrito & 2 & 0,04 \\
\hline Relatório & 6 & 0,13 \\
\hline Online & 6 & 0,13 \\
\hline Tese & 107 & 2,28 \\
\hline Online & 107 & 2,28 \\
\hline Texto Informativo & 260 & 5,54 \\
\hline Impresso & 1 & 0,02 \\
\hline Online & 259 & 5,52 \\
\hline Working Paper & 211 & 4,50 \\
\hline Online & 211 & 4,50 \\
\hline Total Online & 3.995 & 85,18 \\
\hline Total Impresso & 963 & 20,53 \\
\hline Total Manuscrito & 2 & 0,04 \\
\hline Total geral & 4.690 & 100,00 \\
\hline
\end{tabular}


Observemos que $66,63 \%$ dos materiais que constituem as nossas fontes referenciais são artigos, constituindo-se no ranking como o tipo de fonte a que os autores da área contábil mais recorrem; destes, $62,92 \%$ está disponível em periódicos online e 3,11\% online em anais de congressos e encontros. O segundo tipo de fonte mais referenciada são os livros que representam 15,88\% das fontes, $14,45 \%$ dos livros são impressos e 1,54\% foram encontrados online na internet. Os textos informativos são o terceiro tipo de fonte mais consultada e referenciada e perfazem $5,54 \%$ das fontes, seguidos dos working paper com $4,50 \%$ das fontes - preocupa-nos o fato de os working papers serem considerados como fonte para discussões na área contábil, porque os mesmos ainda não constituem publicação definitiva, apesar de isto não ser condição indispensável para julgamento da qualidade do material.

Podemos evidenciar na Tabela 8 o nome da revista ou da instituição que teve mais fontes referenciais citadas:

Tabela 8:

Nome da instituição ou periódico cientifico que está entre as 20 mais referenciadas na RC\&F de 2010 a 2015

\begin{tabular}{lccc}
\hline Instituição ou Periódico Científico & Quantidade & País & $\%$ \\
\hline The Journal of Finance & 149 & Reino Unido & 3,18 \\
Journal of Accounting and Economics & 136 & Holanda & 2,90 \\
The Accounting Review & 131 & EUA & 2,79 \\
Journal of Accounting Research & 95 & Reino Unido & 2,03 \\
Revista Contabilidade \& Finanças & 88 & Brasil & 1,88 \\
Journal of Financial Economics & 80 & Holanda & 1,71 \\
Universidade de São Paulo & 75 & Brasil & 1,60 \\
Accounting, Organizations \& Society & 59 & Reino Unido & 1,26 \\
Accounting, Auditing \& Accountability Journal & 57 & Reino Unido & 1,22 \\
Management Accounting Research & 55 & EUA & 1,17 \\
European Accounting Review & 34 & Reino Unido & 0,72 \\
Accounting Horizons & 34 & EUA & 0,72 \\
Journal of Accounting and Public Policy & 32 & EUA & 0,68 \\
Journal of Business Finance \& Accounting & 32 & Reino Unido & 0,68 \\
Accounting and Business Research & 29 & EUA & 0,62 \\
Contemporary Accounting Research & 29 & Canadá & 0,62 \\
Journal of Banking \& Finance & 27 & Holanda & 0,58 \\
Abacus & 26 & Reino Unido & 0,55 \\
Academy of Management Review & 25 & EUA & 0,53 \\
Journal of Business Ethics & 25 & Holanda & 0,53 \\
Journal of Political Economy & 24 & EUA & 0,51 \\
\hline
\end{tabular}

Os cinco periódicos científicos cujas publicações foram mais citadas são: The Journal of Finance, do Reino Unido, cuja representação no total de referências do período foi 3,18\%; Journal of Accounting and Economics, da Holanda (2,90\% das referências); The Accounting Review, dos EUA (2,79\% das referências); Journal of Accounting Research, do Reino Unido (2,03\% das referências); e a Revista Contabilidade e Finanças do Brasil (1,88\% das referências). Nota-se que dentre as vinte instituições ou periódicos científicos dos quais os 
textos citados se originam, apenas duas delas são do Brasil e ambas vinculadas à USP - vale ressaltar que o periódico brasileiro mais citado é a RC\&F, contexto de estudo e de onde foram extraídos os corpus analisados.

\subsection{Seleção do corpus: foco na hegemonia das linhas de pesquisa da RC\&F}

Para a análise e o desvelamento que realizamos sobre o discurso científico produzido pelas pesquisa contábil no Brasil, adotamos como corpus os artigos científicos publicados pela revista RC\&F. Complementarmente, realizamos entrevistas com membros do corpo editorial de periódicos contábeis brasileiros para compreender a concepção que eles possuem deste discurso, mas a princípio, trataremos apenas do processo de seleção dos referidos artigos.

Os artigos que compõem o corpus da investigação foram publicados de 2001 a 2015 na RC\&F, periódico científico vinculado ao PPGCC da FEA/USP. A RC\&F é um periódico vinculado ao PPGCC mais antigo do país; tal fato lhe concebe uma tradição em pesquisa na área que, potencialmente, a torna o periódico mais conhecido por pesquisadores nacionais e internacionais. Nesta perspectiva, Aragão, Oliveira e Lima (2014) investigaram a ressonância da pesquisa contábil em quatro periódicos classificados nos estratos superiores do Qualis/CAPES de 2012 (periódicos que publicavam exclusivamente assuntos vinculados a área contábil). Os resultados evidenciaram que o maior fator de impacto foi da RC\&F. Tais fatores, atrelados à possibilidade de acesso a informações diretas e pessoalmente à equipe do periódico, nos fizeram tomá-lo como objeto de estudo.

De 2001 a 2015, a RC\&F publicou 51 números os quais se traduzem em 355 artigos publicados, uma média aproximada de sete artigos por número. Os artigos publicados entre 2008 e 2015 (especificamente até o exemplar v. 26 no 68) foram classificados por linha de pesquisa conforme banco de dados cedido pela RC\&F, já aqueles publicados de 2001 a 2007 e o último exemplar de 2015 (v. 26 nº 69) foram por nós classificados.

O processo de composição final dos textos para análise do discurso se deu em quatro etapas. Na primeira etapa, deu-se a codificação do artigo 123, da Linha 2, salvo no Dropbox. A planilha Microsoft Excel 2007 foi utilizada como banco de dados dessa codificação. Os códigos criados obedeceram aos critérios: volume, número da edição e número de ordem no exemplar em que o artigo foi publicado - por exemplo, o primeiro artigo do primeiro volume de 2015 foi codificado como 26.67 .1 (26 representa o número do volume, 67 o número da edição e 1 o número de ordem do artigo conforme sumário) da edição - no caso de edição 
especial, em vez do número da edição, atribuímos o termo "spe” em caso de um único número especial por ano; quando havia dois números especiais, "spe1" e "spe2".

$\mathrm{Na}$ segunda etapa, classificamos os artigos referentes aos sete primeiros anos de publicação online e o último exemplar de 2015 (totalizando 203 artigos). Os artigos foram importados do Dropbox para uma subpasta da pasta "Fontes Internas" do NVivo 11, onde foram criados "nós", um para cada linha de pesquisa. À medida que a temática ia sendo identificada o artigo era classificado no "nó" referente; a identificação se deu em função de elementos como título, resumo e introdução - quando necessário, verificou-se a revisão de literatura e a conclusão.

Até 2014 a RC\&F possuía cinco linhas de pesquisa: Controladoria e contabilidade gerencial; Contabilidade para usuários externos; Mercados: financeiro, de crédito e de capitais; Educação e pesquisa em contabilidade, controladoria, atuária e finanças e Atuária, denominadas como Linha1, Linha 2, Linha 3, Linha 4 e Linha 5, respectivamente. Todavia, conforme relatamos na seção 3.1 desta tese, para uma edição especial comemorativa dos seus 25 anos a RC\&F publicou artigos classificados como "História da contabilidade" - linha criada com o fim específico de atender às características temáticas do material publicado no referido número.

Além das cinco linhas citadas anteriormente, a RC\&F criou, em 2015, a linha "Temas emergentes em contabilidade, finanças e atuária". Desta maneira, o periódico possui atualmente seis linhas de pesquisa - ressaltamos não haver identificado entre os trabalhos publicados pela RC\&F em 2015 aqueles que pudessem ser classificados nesta linha. Julgamos que esse fato se deve à tímida tradição de estudos na área contábil que se enquadrassem nas especificações propostas. Esse fato foi observado quando da experiência de análise do material da revista e se ratifica pela iniciativa de criação da nova linha. Salientamos o significado e a importância que este espaço de publicação representa para a disseminação das pesquisas de caráter interdisciplinar, como propõe a RC\&F - o detalhamento sobre as linhas de pesquisas propostas será retomado, em detalhes, no Capítulo 3. No final dessa etapa, os artigos que já estavam classificados em conformidade com informações fornecidas pela RC\&F foram também classificados nos "nós" da linha a que pertencem.

A Figura 11, a seguir, apresenta a classificação de todos os artigos publicados pela RC\&F de 2001 até 2015 em valores relativos; as informações foram selecionadas a partir de 2001, porque foi o ano em que o periódico passou a ser online. 
Distribuição dos artigos publicados pela RC\&F por linha de pesquisa nos últimos 15 anos
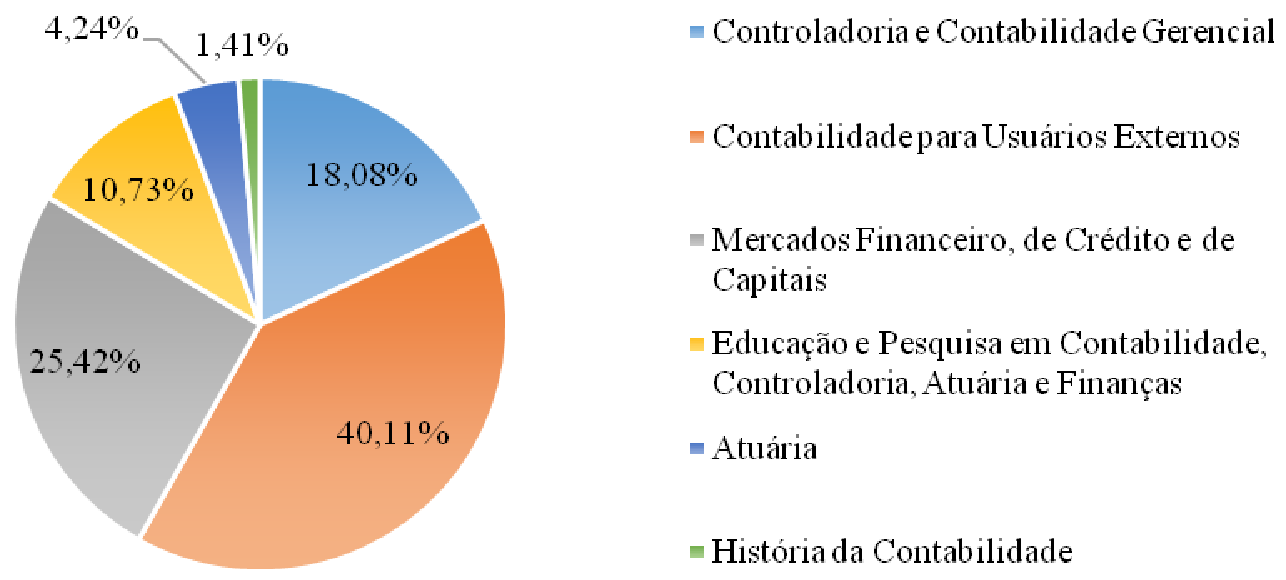
Capitais

Educação e Pesquisa em Contabilidade, Controladoria, Atuária e Finanças

- Atuária

- História da Contabilidade

Figura 11. Distribuição dos artigos publicados pela Revista Contabilidade e Finanças (RC\&F) por linha de pesquisa nos últimos 15 anos.

Os 355 artigos publicados pela RC\&F (2001-2015) se distribuem da seguinte maneira: 18,08\% referentes à "Linha 1 - Controladoria e contabilidade gerencial"; 40,11\% à "Linha 2 - Contabilidade para usuários externos"; 25,42\% à "Linha 3 - Mercados: financeiro, de crédito e capitais"; $10,73 \%$ à "Linha 4 - Educação e pesquisa em contabilidade, controladoria, atuária e finanças"; $4,12 \%$ à "Linha 5 - Atuária" e 1,41\% classificados como "História da contabilidade". Trataremos na maioria das vezes como Linha 1, Linha 2, Linha 3, Linha 4 e Linha 5, respectivamente. Vale destacar que existe a possibilidade de um mesmo artigo ser enquadrado em mais de uma linha de pesquisa em função da temática abordada pelo autor; todavia os artigos foram classificados apenas uma vez e correspondem à nossa interpretação acerca desses estudos. A opção do enquadramento do artigo em uma linha e não em outra representa a nossa forma de interpretar o seu conteúdo. Ademais, se procedêssemos às classificações de outra forma, não haveria modificações significativas nos percentuais obtidos e tampouco na hierarquia quantitativa que esses valores relativos representam. Outro ponto a destacar é que, por não haver publicação vinculada, não representaremos a Linha 6 (Temas emergentes em Contabilidade, Finanças e Atuária) nas discussões que se seguem.

A Figura 12, a seguir, representa o comportamento das publicações da RC\&F por linha de pesquisa no período de 2001 a 2015. Detalharemos as informações acerca desse comportamento, visto que ele representa a trajetória que percorremos para a escolha dos textos/discursos que analisamos. 


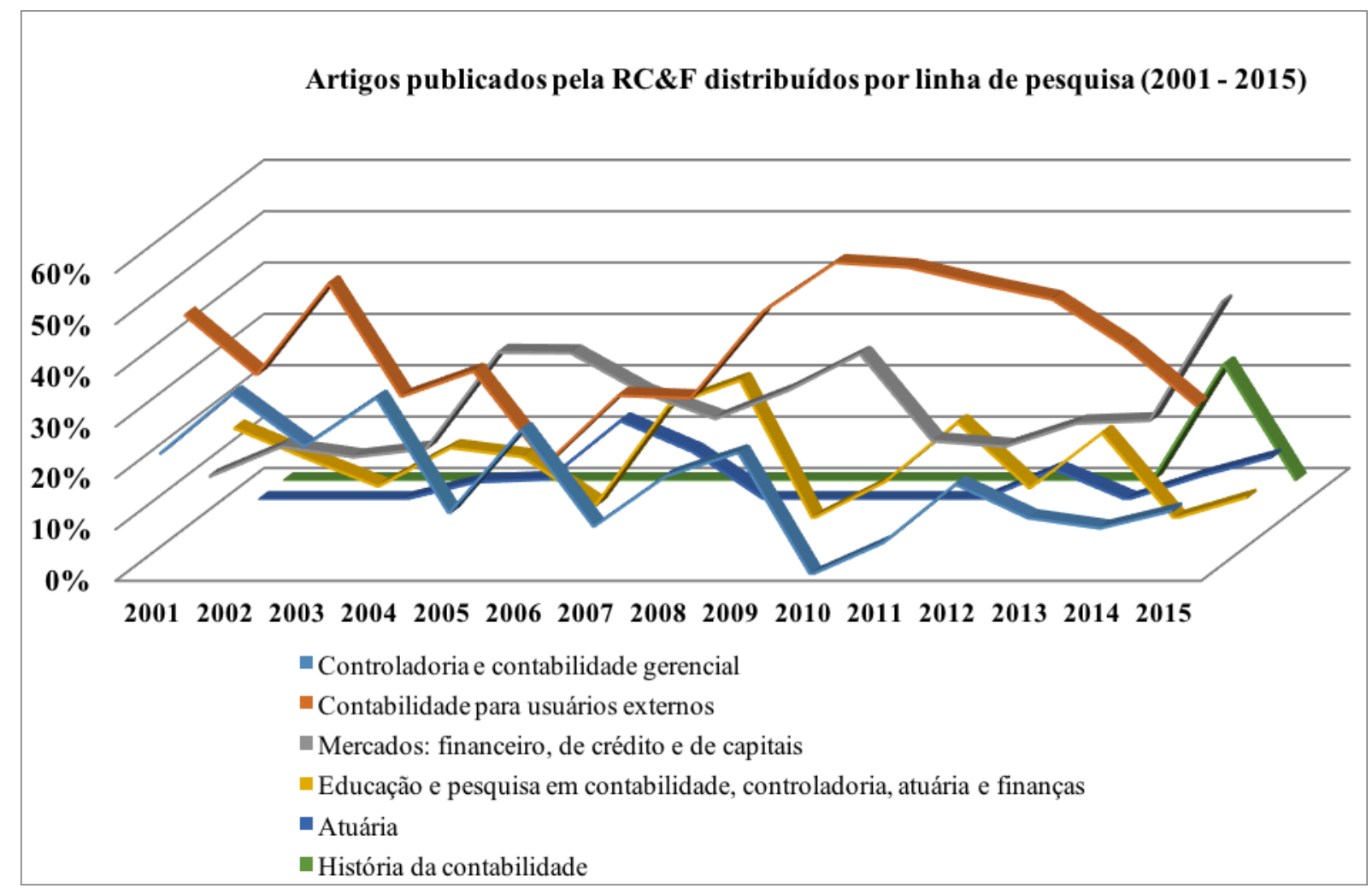

Figura 12. Comportamento da distribuição dos artigos publicados na Revista Contabilidade e Finanças (RC\&F) por linha de pesquisa entre 2001 e 2015.

Percebe-se que há uma prevalência e continuidade do fluxo de publicações nas Linhas 2 e 3 . O volume de artigos publicados da Linha 2 supera os referentes às Linha 3 entre os anos 2001- 2004. Em 2005, essa publicação se iguala (36\% em ambas as linhas) e em 2006 o quantitativo de artigos publicados na Linha 3 (35\%) supera aqueles da Linha 2 (20\%). Nos três anos seguintes $(2007,2008$ e 2009) a RC\&F volta a publicar mais artigos da Linha 2 $(30 \%, 31 \%$ e $41 \%)$ que da Linha $3(27 \%, 23 \%, 27 \%)$, valores respectivos.

Em 2010, 57\% dos artigos publicados pela RC\&F vincularam-se à Linha 3, e nesse mesmo ano $27 \%$ à Linha 2 . No ano seguinte, esse panorama tornou-se praticamente inverso, $50 \%$ das publicações vincularam-se à Linha 2 e 25\% à Linha 3, em 2011. Os anos de 2012, 2013, 2014 e 2015 se caracterizam por haver uma oscilação contínua entre as publicações da Linha 2 e Linha 3 - os percentuais são respectivamente $33 \%$, 28\%, 35\% e 33\% e $28 \%$, 39\%, $26 \%$ e $42 \%$. Por estes resultados podemos inferir que ao longo dos 15 anos de publicação online há uma média anual de 35\% dos artigos para a Linha 2 (124 publicações de um total de 355 artigos) e $28 \%$ para a Linha 3.

Os percentuais citados evidenciam que, apesar de haver uma prevalência nos primeiros 5 anos da Linha 2 (fase em que os textos apresentam um discurso normativo), se analisarmos todo o período de publicação online temos um quantitativo de artigos publicados 
muito próximo para essas linhas - isto se torna mais evidente quando tomamos a quantidade média de artigos publicados anualmente: 8 artigos na Linha 2 e 7 artigos na Linha 3. Optamos por analisar os artigos da Linha 2 - Contabilidade para usuários externos, porque possui fluxo perene de publicações e é, atualmente, a linha prevalente da RC\&F, ou seja, hegemônica no decorrer dos 15 anos de publicação online (ver Figura 12).

Após a classificação por linha, procedemos à terceira etapa do processo de seleção dos textos para análise em profundidade. Nesta etapa, realizamos um exame mais detalhado dos 124 artigos da linha Contabilidade para usuários externos a fim de procedermos a uma subclassificação temática feita em "nós" do NVivo; consideramos o resumo, a introdução, a revisão de literatura e a conclusão de cada artigo. Identificamos nove abordagens temáticas (AT) que são eixos de discussão dos 124 artigos: Contabilidade Social (AT1), Auditoria Independente (AT2), Normas Contábeis (AT3), História da Contabilidade (AT4), Teoria da Contabilidade (AT5), Contabilidade Governamental (AT6), Governança Corporativa (AT7), Novas Tecnologias e a Contabilidade (AT8) e Contabilidade Societária (AT9). A princípio, a classificação dos artigos nas abordagens/temáticas da linha hegemônica, citadas anteriormente, buscou evidenciar agrupamentos que refletissem congruências entre os trabalhos. A nossa interpretação está condensada na Figura 13, a seguir.

Para as Abordagens Temáticas (ATs), eixos da Contabilidade Social (AT1), Teoria da Contabilidade (AT5) e Contabilidade Societária (AT6), foram criadas subabordagens, isto porque, há uma diversidade de assuntos nas Ats, e para chegarmos às proximidades que encontramos tornou-se imprescindível imprimir esse olhar ao corpus. Na AT1 havia textos sobre Contabilidade Ambiental (AT1.1), Contabilidade de Recursos Humanos (AT1.2) e Ética (AT1.3); na AT5, por sua vez, emergiram textos sobre Valor Justo (AT5.1), Informação Contábil (AT5.2), Intangíveis (AT5.3), Propriedades para Investimento (AT5.4), Estrutura Conceitual (AT5.5) e Conservadorismo (AT5.6). As discussões propostas na AT9 tratam sobre Fluxo de Caixa (AT9.1), Demonstração de Valor Adicionado (AT9.2), Consolidação (AT9.3) e Evidenciação (AT9.4). 


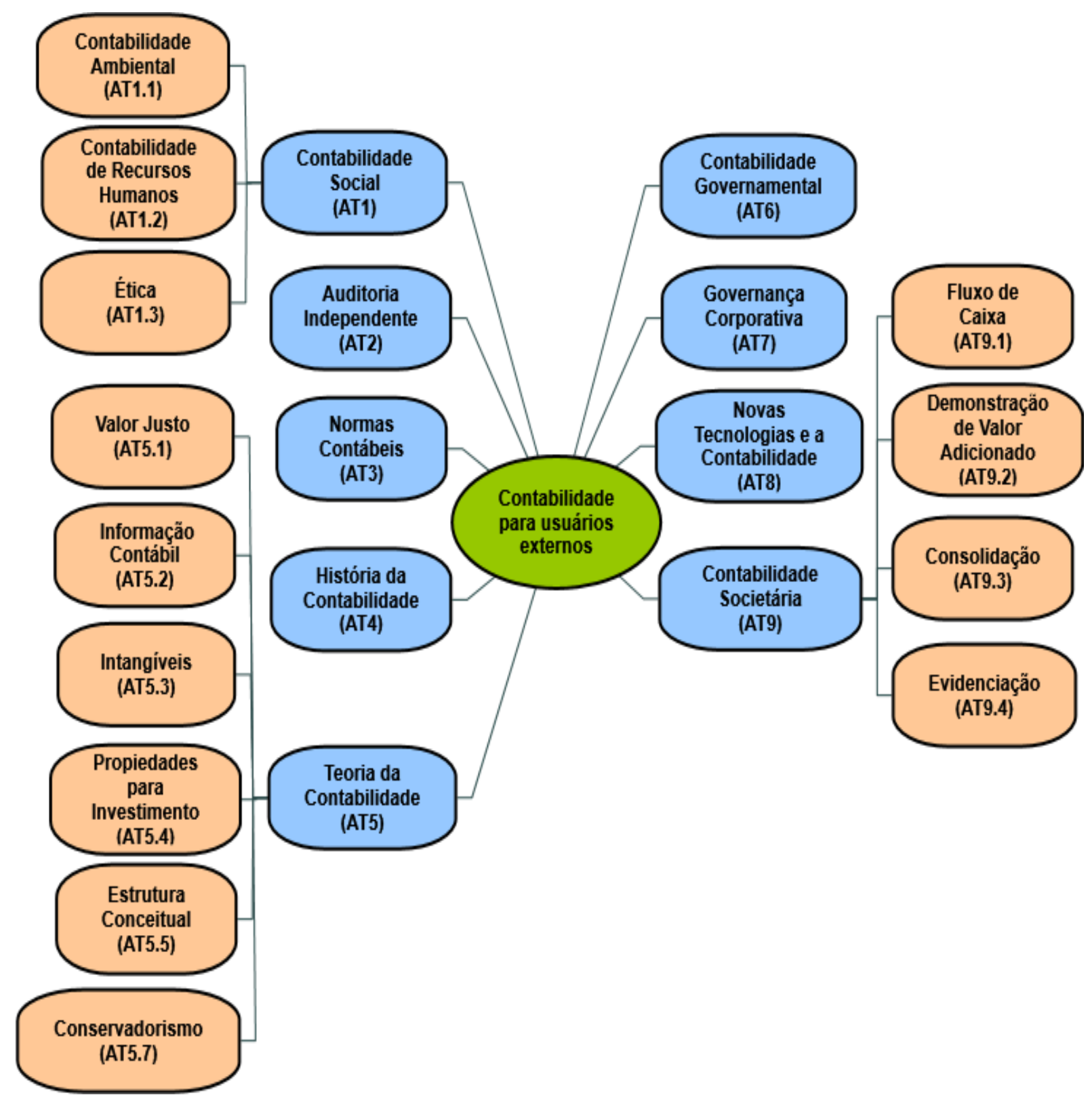

Figura 13. Abordagens Temáticas (ATs) dos artigos publicados na Linha 2 "Contabilidade para usuários externos" - Revista Contabilidade \& Finanças (RC\&F) de 2001 a 2015.

Na Figura 14 examinamos a possibilidade de haver no corpus: investigações com mesma teoria para análise de objetos distintos, propostas de pesquisa semelhantes em termos de objetivo e estratégias metodológicas diferentes e/ou objetos de estudo distintos, mesmo objeto de estudo e propostas investigativas distintas, dentre outras. Assim, as subdivisões das ATs e o mapeamento e mineração do corpus no NVivo 11 foram etapas imprescindíveis ao nosso processo de interpretação e identificação das proximidades encontradas nos textos. A Figura 14 demonstra a distribuição anual dos artigos por abordagem temática (AT). As codificações de mesma cor indicam mesma abordagem conforme legenda. 


\begin{tabular}{|c|c|c|c|c|c|c|c|c|c|c|c|c|c|c|}
\hline 2001 & 2002 & 2003 & 2004 & 2005 & 2006 & 2007 & 2008 & 2009 & 2010 & 2011 & 2012 & 2013 & 2014 & 2015 \\
\hline 12.25 .1 & 13.28 .2 & 14.31 .2 & 15.34 .2 & 16.37 .1 & 17.40 .5 & 18.43 .2 & 19.48 .2 & 20.51 .3 & 21.54 .1 & 22.57 .1 & 23.60 .2 & 24.63 .3 & 25.66 .2 & 26.67 .3 \\
\hline AT9.1 & AT2 & AT9.4 & AT2 & AT9.2 & AT2 & AT1.1 & AT5.6 & AT6 & AT5.6 & AT3 & AT9.4 & AT6 & AT5.2 & AT2 \\
\hline 12.25 .2 & 13.28 .4 & 14.31 .5 & 15.34 .3 & 16.37 .7 & 17.40 .7 & 18.43 .6 & 19.48 .3 & 20.51 .4 & 21.54 .5 & 22.57 .2 & 23.60 .3 & 24.63 .4 & 25.66 .3 & 26.67 .4 \\
\hline AT8 & AT5.5 & AT9.1 & AT9.3 & AT2 & AT5.1 & AT6 & AT9.1 & AT7 & AT5.6 & AT9.4 & AT6 & AT6 & AT6 & AT5. 2 \\
\hline 12.25 .5 & 13.29 .1 & 14.31 .7 & 15.34 .6 & 16.38 .1 & 17.41 .1 & 18.43 .7 & 19.48 .8 & 20.51 .7 & 21.53 .4 & 22.57 .4 & 23.60 .6 & 24.62 .1 & 25.66 .4 & 26.68 .1 \\
\hline AT8 & AT3 & AT6 & AT2 & AT4 & AT5.6 & AT2 & AT3 & AT1 & AT2 & AT9.1 & AT2 & AT6 & AT5.2 & AT3 \\
\hline 12.26 .3 & 13.29 .3 & 14.32 .2 & 15.35 .1 & 16.38 .2 & 17.41 .7 & 18.44 .5 & 19.48 .9 & 20.50 .2 & 21.52 .3 & 22.56 .1 & 23.59 .3 & 24.62 .3 & 25.66 .5 & 26.68 .3 \\
\hline AT5.2 & AT5.3 & AT9.4 & AT9.1 & AT9.4 & AT3 & AT1.3 & AT2 & AT3 & AT3 & AT1.1 & AT6 & AT1.1 & AT3 & AT5.4 \\
\hline 12.26 .5 & 13.30 .4 & 14.32 .6 & 15.35 .2 & 16.39 .1 & 17.42 .8 & 18.45 .3 & 19.47 .3 & 20.50 .3 & & 22.56 .2 & 23.58 .5 & 24.61 .2 & 25.65 .2 & 26.68 .5 \\
\hline AT5.5 & AT1.1 & AT5.3 & AT2 & AT9.3 & AT5.5 & AT5.2 & AT9.1 & AT9.4 & & AT3 & AT5.6 & AT7 & AT3 & AT3 \\
\hline 12.27 .2 & & 14.32 .7 & 15.35 .5 & 16.39 .5 & 17. spe1.5 & 18.45 .4 & 19.47 .7 & 20.50 .4 & & 22.56 .3 & 23.58 .4 & & 25.65 .4 & 26.69 .2 \\
\hline AT8 & & AT6 & AT1.1 & AT9.4 & AT7 & AT9.4 & AT1 & AT2 & & AT5.6 & AT3 & & AT3 & AT2 \\
\hline 12.27 .3 & & 14.32 .8 & 15.35 .7 & 16.39 .7 & 17.spe1.6 & 18.45 .8 & 19.47 .9 & 20.50 .6 & & 22.56 .5 & & & 25.64 .1 & 26.69 .3 \\
\hline AT9.3 & & AT5. 2 & AT6 & AT5.5 & AT2 & AT2 & AT3 & AT5.6 & & AT6 & & & AT2 & AT5.4 \\
\hline 12.27 .7 & & 14.33 .3 & 15.36 .1 & 16.39 .8 & 17.spe1.7 & 18.spe. 1 & 19.46 .8 & 20.50 .7 & & 22.55 .3 & & & 25.64 .5 & 26.69 .5 \\
\hline AT1.1 & & AT5.6 & AT9.4 & AT3 & AT7 & AT5.1 & AT6 & AT9.2 & & AT6 & & & AT1.1 & AT3 \\
\hline
\end{tabular}

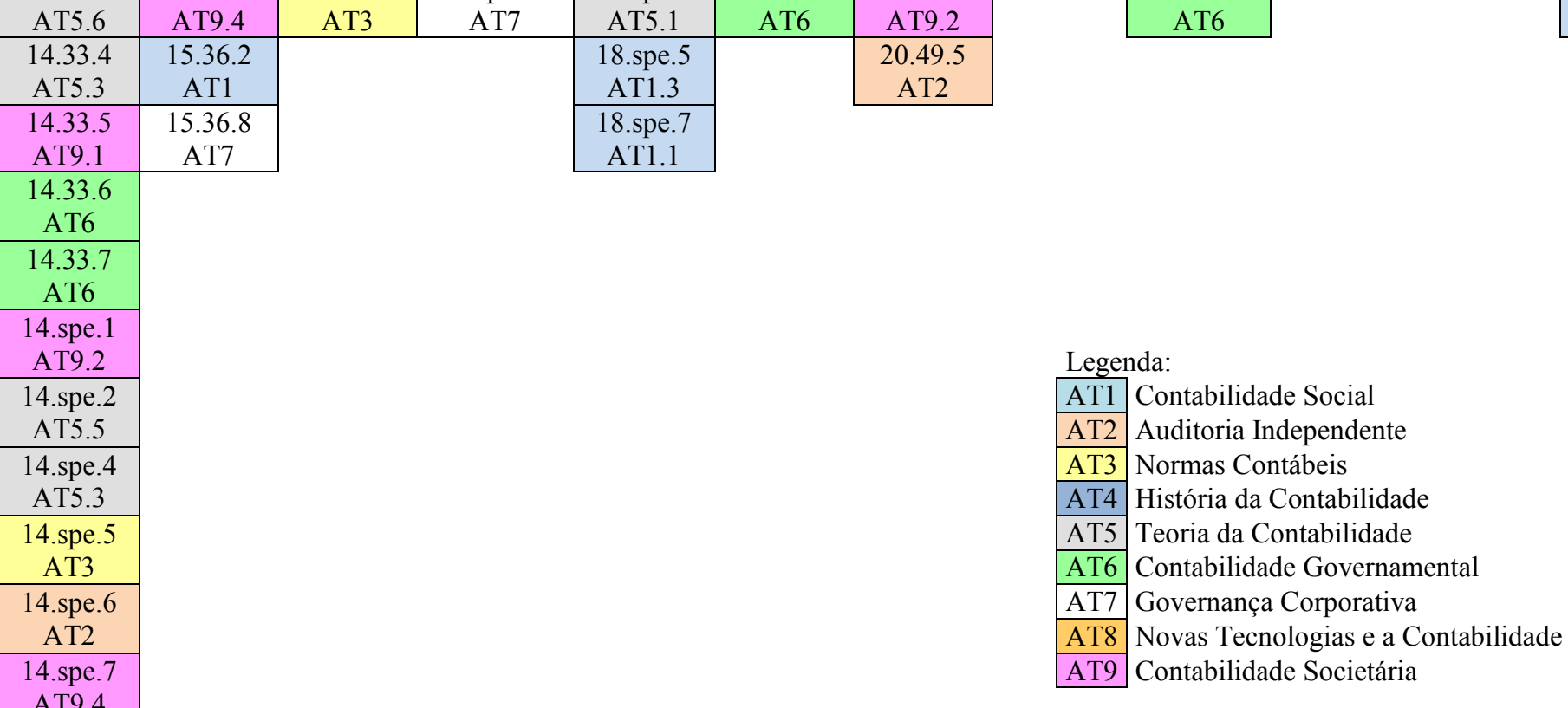

Figura 14. Agrupamentos dos artigos da RC\&F da linha "Contabilidade para usuários externos" por abordagem temática (2001-2015). 
Após a codificação e identificação do conteúdo abordado no âmbito da linha, iniciamos a quarta etapa, na qual organizamos agrupamentos que nos permitiram identificar similaridades em torno das propostas, tais como: 14.32 .2 (2003) e 16.39 .5 (2005) classificados na AT9.4; 12.26 .5 (2001) e 14.spe.2 (2003) classificados na AT5.5; 20.49 .5 (2009) e 22.56 .5 (2011) classificados na AT2. Todavia, percebemos que, apesar de refletirem as situações procuradas - conforme citamos anteriormente - os trabalhos foram publicados há mais de 5 anos, logo não refletem o discurso vinculado a pesquisas atuais. $\mathrm{O}$ mesmo ocorre com os artigos 12.27.7, 13.30.4, 15.35.5, 18.43.2, 22.56.1 e 24.62.3 da abordagem temática da Contabilidade Social (AT1). Esses artigos tratam sobre a Contabilidade Ambiental nos anos de 2001, 2002, 2004, 2007, 2011 e 2013, respectivamente. Os seus objetivos estão descritos na Tabela 9 a seguir:

Tabela 9:

Objetivos dos artigos publicados pela RC\&F agrupados na AT1.1

\begin{tabular}{|c|c|c|}
\hline Artigo & Ano & Contabilidade Ambiental (AT1.1) \\
\hline 12.27 .1 & 2001 & $\begin{array}{l}\text { Discutir sobre conhecimentos e aplicação da Contabilidade Ambiental em indústrias } \\
\text { brasileiras poluidoras. }\end{array}$ \\
\hline 13.30 .4 & 2002 & Fundamentar propostas de contabilização e evidenciação das externalidades ecológicas. \\
\hline 15.35 .5 & 2004 & $\begin{array}{l}\text { Evidenciar a aplicabilidade da Contabilidade Ambiental para entendimento e controle de } \\
\text { gastos ambientais em uma indústria madeireira na Amazônia. }\end{array}$ \\
\hline 18.43 .2 & 2007 & $\begin{array}{l}\text { Verificar a uniformidade das informações ambientais em relatórios disponibilizados pelas } \\
\text { empresas de papel e celulose. }\end{array}$ \\
\hline 22.56 .1 & 2011 & $\begin{array}{l}\text { Verificar se as práticas de evidenciação ambiental reagem aos estímulos regulatórios de } \\
\text { seus países de origem. }\end{array}$ \\
\hline 24.62 .3 & 2013 & Evidenciar a contabilização dos resíduos sólidos em companhias abertas brasileiras. \\
\hline
\end{tabular}

As pesquisas mencionadas também contêm discursos sobre a Contabilidade Ambiental distribuídas de maneira longitudinal, sendo que a mais antiga publicada em 2001 e a mais atual em 2013. Seguindo os critérios de seleção anteriormente mencionados, não havia além da abordagem temática similaridades que justificasse a seleção das mesmas para análise.

Como o nosso interesse volta-se a um discurso hegemônico situado em lapso temporal mais atual possível, passamos a verificar os trabalhos 22.56.5, 22.55.3, 23.60.3, 23.59.3, 24.63.3, 24.63.4, 24.62.1, 25.67.4 da AT6 e 22.57.1, 22.56.2, 23.58.4, 25.66.5, 25.65.2, 22.65.4, 26.68.5, 26.69.5 e 26.68.1 da AT3, publicados de 2011 a 2015, porém, também não identificamos similaridades/congruências conforme descrevemos anteriormente.

Ao verificarmos o agrupamento AT5.2 Teoria da Contabilidade, identificamos os artigos 26.68.3 e 26.69.3, publicados em 2015, que tratam sobre Propriedade para Investimento; bem como os artigos 25.66.2 e 26.67.4, publicados em 2014 e 2015, que tratam sobre Informação Contábil (AT5.2). Optamos por este último agrupamento por entendermos 
que o mesmo atende ao critério similaridade e ao critério atualidade ponderado na análise de cada agrupamento.

\subsection{O discurso científico em artigos da área contábil: seleção dos entrevistados}

Complementarmente à análise dos artigos 25.66 .2 e 26.67.4, cuja seleção foi descrita na seção anterior, realizamos entrevistas com membros do corpo editorial de periódicos contábeis brasileiros e um editor internacional - a quem nos referimos no texto da tese como Pesquisadores Entrevistados (PE).

Em agosto de 2015, encaminhamos 25 e-mails convites para participação na entrevista sobre a pesquisa contábil e obtivemos 19 confirmações. As entrevistas foram realizadas nos meses de agosto e setembro com 17 editores de revistas que publicam, exclusivamente, artigos da área contábil, além de dois membros do corpo editorial (pesquisadores selecionados em função da visibilidade nacional, produtividade em pesquisa e representatividade internacional) e um editor de periódico contábil internacional.

As entrevistas foram realizadas presencialmente e por Skype. Estimamos o tempo médio de 30 minutos para o diálogo com cada PE. Ao final do processo, computamos 593 minutos de entrevistas - uma média de aproximadamente 32 minutos por PE. A entrevista foi semiestruturada, e norteada, inicialmente, pelas perguntas: 1) Quais características atribuiria para a pesquisa contábil no Brasil disseminada por meio do artigo científico? Como as descreveria? 2) Quais características atribuiria para a pesquisa contábil internacional disseminada por meio do artigo científico? Como as descreveria? 3) Quais características atribuiria ao discurso científico contábil que compõe os artigos publicados em periódicos nacionais e internacionais (contribuição, inovação, postura crítica do autor). Como o descreveria? A entrevista semiestruturada caracteriza-se por questionamentos básicos que propiciam a descrição, explicação e compreensão dos fenômenos sociais; o pesquisador é ser consciente e atuante no processo de coleta das informações (Triviños, 1987; Martins \& Theóphilo, 2009). Assim, à medida que o PE se pronunciava, realizaram-se questões acessórias que objetivavam conduzi-lo à discussão central e obter informações mais completas.

Entre novembro e dezembro de 2015, as transcrições foram realizadas por empresa especializada e, ainda no início de dezembro de 2015, estas foram totalmente recebidas. Recebidas as transcrições, encaminhamos e-mails com o conteúdo transcrito e o Termo de Consentimento Livre e Esclarecido (TCLE) a cada um dos PEs, a fim de que eles pudessem 
avaliar o material transcrito, realizando, inclusive, edições caso julgassem necessárias. A partir do e-mail encaminhado (Apêndice B), esclarecemos que, caso discordasse do teor da entrevista e decidisse declinar da participação na pesquisa, o entrevistado teria o prazo de dez dias da data do envio do e-mail para nos responder com a negativa - solicitação de sua exclusão no processo. Esclarecemos ainda que, não havendo manifestação contrária, as entrevistas seriam consideradas como material disponível para apreciação e, conseguinte publicação de seus resultados, observados todos os aspectos acordados por meio do TCLE.

Houve apenas o declínio de um PE. Assim, observado o prazo de dez dias da emissão dos e-mails com a transcrição e TCLE, realizamos o processo analítico com base no teor das 18 entrevistas. O processo de apreciação das entrevistas foi realizado por meio do Software Nvivo. Inicialmente, salvamos todo o material transcrito para análise na pasta de "fontes internas" e por meio da ferramenta de "Consulta" da "frequência de palavras" executamos a busca das 50 palavras mais frequentes com comprimento mínimo de quatro caracteres em todas as transcrições, eliminando aquelas palavras que não guardavam sentido. Dentre as palavras mais frequentes evidenciadas, selecionamos o termo "discurso" e pedimos a consulta da palavra no texto para que o NVivo pudesse referenciar todas as falas a que o termo se vinculava; em seguida pedimos a apresentação em contexto de codificação "largo". Após visualização no modo de contexto largo, realizamos a categorização dos termos por meio de "nós" a fim de extrairmos as características do discurso científico contábil na concepção dos pesquisadores entrevistados. 



\section{A ANÁLISE DO DISCURSO CIENTÍFICO CONTÁBIL}

Neste capítulo, apresentamos a nossa interpretação sobre o corpus selecionado. Analisamos o significado das palavras, a coesão textual e a intertextualidade manifesta no discurso dos artigos da área contábil. De acordo com Fairclough (2008) a análise do significado das palavras tem ênfase nos vocábulos chave, cujo significado cultural pode ser mais amplo ou mais local - analisamos, especificamente, os estrangeirismos, a frequência e a polaridade semântica das palavras (positiva ou negativa) e, em seguida, estabelecemos uma classificação de acordo com o campo que em nosso entendimento essas palavras são mais aplicadas. Verificamos, também, a coesão textual a partir das relações argumentativas de Koch (2010) e a intertextualidade manifesta dos textos que, conforme Fairclough (2008) evidencia as características que emergem da superfície do texto, ou seja, os textos que constituem o texto que está sendo analisado.

Esse conjunto analítico nos propiciou uma visão acerca do desempenho discursivoargumentativo dos artigos tomados para análise a partir da concepção de Fairclough (2008): um discurso que transmite e reflete variáveis situacionais de maneira não individualista, no qual a linguagem é expressão de prática social - prática política e ideológica, concomitantemente. Prática política porque tanto constitui quanto mantém ou transforma estruturas de poder nas entidades coletivas, no caso desta tese focamos o poder estabelecido tacitamente pela forma de pensar e elaborar o discurso científico na área contábil. Prática ideológica porque ela está imbricada à prática política, categoria superior, e diz respeito à capacidade de naturalização, manutenção e transformação das concepções de mundo que emergem silenciosamente por meio do exercício e da luta nas relações silenciosas de poder. Somos de opinião que no discurso científico a ideologia leva a replicações, elaboração de "produções oportunistas", produção de textos frágeis no que diz respeito à capacidade crítica e inovação, conforme descrevemos na Introdução deste trabalho.

Após a apreciação dos elementos descritos anteriormente, procedemos à análise das entrevistas a fim de identificarmos na concepção dos pesquisadores entrevistados sobre o discurso científico da área. A partir dessa opinião, extraímos características que nos auxiliaram de maneira significativa a consolidar nossas reflexões acerca dos achados.

\subsection{Exame do corpus: artigos 25.66.2 e 26.67.4}

Examinaremos os artigos “O efeito da adoção dos IFRS sobre a relevância 
Informacional do lucro contábil no Brasil" (25.66.2) e "Análise da Relevância do Conteúdo Informacional da DVA no mercado brasileiro de capitais" (26.67.4), corpus selecionado conforme descrevemos na Seção 2.7 desta tese.

O nosso interesse está na argumentação presente nos textos científicos dado que é por meio dela que o autor constitui seu discurso no qual pode envolver seu leitor. Os operadores argumentativos, portanto, imprimem determinado sentido ao texto e o seu uso inadequado/equivocado pode acarretar em sérios ruídos de comunicação discursiva, comprometer a qualidade do texto científico que culmina em falta de profundidade semântica e repetição de ideias que tornam opaca a contribuição do estudo e pode persuadir o leitor a respeito de sua importância. Por este motivo nos deteremos na análise destes operadores.

Para além de representar a metodologia adotada, entendemos essa análise argumentativa do discurso proposta por Faircoulgh (2001) como a maneira mais didática e lógica de apresentar as modestas incursões interpretativas que realizamos. A análise do discurso de Fairclough tanto nos propiciou intimidade com o corpus por meio da descrição quanto da interpretação. Em seguida, análise das entrevistas nos fez identificar as características desse discurso na ótica dos pesquisadores entrevistados.

Tomamos os artigos 25.66.2 e 26.67.4 para análise, a seleção se deu conforme descrito na metodologia. O objetivo anunciado pelos autores do artigo 25.66 .2 foi: "avaliar, no cenário brasileiro, o efeito da adoção dos International Financial Reporting Standards (IFRS) sobre a relevância informacional do lucro líquido, visando, assim, contribuir com uma maior compreensão do tema"4 (Tópico $1, \S 3^{\underline{0}}$, p. 229). A investigação por eles realizada se constitui em uma análise do comportamento do lucro trimestral de 246 firmas de capital aberto utilizando-se de método estatístico (regressões combinadas e modelos de dados em painel). $\mathrm{O}$ método utilizado para análise do efeito da adoção das normas IFRS, bem como as hipóteses estabelecidas, nos permite identificar o forte apelo quantitativo no estudo. A lacuna que se buscou preencher foi delimitada por meio da comparação de resultados de investigações anteriores, tanto no âmbito nacional quanto internacional.

Assim, a estratégia de argumentação utilizada para evidenciar a lacuna de pesquisa se deu por meio de concepções contrastantes, visto que há contraposição de resultados de pesquisas de outros autores que delimitam o curso a ser seguido pelos autores do artigo 25.66.2 a fim de alcançar a resposta para o problema de pesquisa elaborado. Ao identificarem as consequências da adoção do IFRS, os autores fazem emergir dois agrupamentos de

\footnotetext{
${ }^{4}$ Nossos esforços estão direcionados ao exame do discurso latente nos artigos, por isso não há citação.
} 
pesquisas internacionais, cujos achados contrastam entre si: o primeiro, formado por resultados de pesquisa publicados nos Estados Unidos (EUA), Grécia e Holanda - evidenciam os aspectos positivos em decorrência da adoção desse padrão. O segundo, formado por resultados de pesquisa publicados nos Estados Unidos, Romênia, Canadá e Reino Unido seus achados apontam a inalteração ou deformidade dos aspectos informacionais após a adoção do IFRS. Esses agrupamentos ratificam que não há uma concepção consolidada acerca de aos efeitos/reflexos causados pela convergência das normas IFRS.

Os autores do artigo 25.66.2 se utilizam da mesma estratégia argumentativa para fazer alusão aos resultados de pesquisas publicadas no âmbito nacional, ou seja, há formação de dois agrupamentos que possuem resultados antagônicos entre si no que diz respeito aos efeitos/reflexos da adoção do IFRS no Brasil. Somos de opinião que essa estratégia de contraposição de resultados é valorosa no que diz respeito às reflexões que pode suscitar aos leitores (consumidores do texto), bem como para situá-lo acerca dos achados brasileiros sobre o tema e fazê-lo perceber o estado da arte relacionado no contexto brasileiro.

Já no artigo 26.67.4, o objetivo anunciado pelos autores foi: "analisar a relevância do conteúdo informacional da Demonstração do Valor Adicionado (DVA) no mercado de capitais brasileiro" (Tópico $1, \S 9^{\circ}$, p. 229) e, secundariamente, "analisar se a RCPA representava uma melhor proxy para o resultado que o lucro líquido por ação (LLPA)". Os autores analisaram os dados de 2005 a 2011 de empresas não-financeiras de capital aberto publicadas pelo anual da Revista Exame entre as melhores e maiores, por meio da regressão linear. Da mesma forma que no artigo anterior, há nessa pesquisa uma estratégia metodológica marcada fundamentalmente por estratégia quantitativa. A lacuna de pesquisa é evidenciada em meio a uma discussão acerca da importância da contabilidade social de como ela pode influenciar e mudar o comportamento do usuário.

Compreendidas as propostas de estudo, o desenho metodológico e as lacunas que os artigos buscam preencher passemos à análise dos elementos textuais. A princípio examinamos a coesão textual nos utilizando de operadores argumentativos e do léxico utilizado para a construção dos atos de fala. Salientamos que os aspectos discutidos na seção 4.2 desta tese referem-se especificamente ao estudo do corpus que selecionamos para análise (artigos 25.66.2 e 26.67.4). Entendemos que a análise destes elementos propicia a evidenciação da uma hegemonia que se dá na tessitura do texto, no modo de argumentar a favor de uma temática construída por um processo científico. 


\subsection{Análise da coesão textual por meio das relações argumentativas}

Examinamos a coesão na estrutura frástica dos artigos e identificamos os tipos de argumentações utilizadas pelos autores dos artigos a fim de confrontamos com os encadeadores/operadores argumentativos baseado em Koch (2010) - essa análise esteve atrelada a dimensão texto na perspectiva de discurso apresentada por Fairclough (2008).

Conforme lemos em Koch (2010), nos estudos de semântica argumentativa aprendemos que os encadeadores argumentativos ligam os enunciados (orações) do texto que representam diferentes atos de fala a fim de determinar a orientação argumentativa que se segue. Desta maneira, o uso equivocado desses mecanismos de coesão pode resultar em dificuldade de compreensão do texto. A ocorrência dos encadeamentos pode se dar tanto no mesmo período quanto entre dois ou mais períodos e, ainda, entre parágrafos do texto, estabelecendo relações denominadas como pragmáticas ou argumentativas. A Tabela 10, a seguir, contém as relações argumentativas que contribuem para a coesão textual, algumas delas foram identificadas no texto do nosso corpus de estudo.

Tabela 10:

Operadores para estruturação de textos nas relações discursivas, conforme Koch (2010)

\begin{tabular}{|c|c|c|}
\hline $\begin{array}{c}\text { Operadores } \\
\text { Argumentativos }\end{array}$ & Codificação & Função no texto conforme Koch (2010) \\
\hline Conjunção & A & Liga enunciados que constituem argumentos para a mesma conclusão. \\
\hline Disjunção & $\mathrm{B}$ & $\begin{array}{l}\text { Conexão de enunciados com orientações discursivas diferentes, de forma } \\
\text { que, por meio do segundo procura-se provocar o consumidor do texto a } \\
\text { fim de modificar a sua opinião ou fazê-lo aceitar aquela expressa no } \\
\text { primeiro enunciado. }\end{array}$ \\
\hline Contrajunção & $\mathrm{C}$ & $\begin{array}{l}\text { Contraposição de enunciados de orientações argumentativas distintas, em } \\
\text { que prevalece a orientação introduzida pelo conectivo (exceto para } \\
\text { embora, quando prevalece a orientação argumentativa do enunciado não } \\
\text { introduzido pelo operador). }\end{array}$ \\
\hline $\begin{array}{l}\text { Explicação ou } \\
\text { Justificativa }\end{array}$ & $\mathrm{D}$ & $\begin{array}{l}\text { Encadeia um ato de fala de maneira que o segundo explica ou justifica o } \\
\text { primeiro }\end{array}$ \\
\hline Comprovação & $\mathrm{E}$ & $\begin{array}{l}\text { Por meio de um novo ato de fala, acrescenta-se uma possível } \\
\text { comprovação da asserção apresentada no primeiro. }\end{array}$ \\
\hline Conclusão & $\mathrm{F}$ & $\begin{array}{l}\text { Introduz um enunciado conclusivo em relação a dois ou mais atos de fala } \\
\text { anteriores que contém as premissas. }\end{array}$ \\
\hline Comparação & G & $\begin{array}{l}\text { Argumentação que acontecem sempre com vistas a uma conclusão a } \\
\text { favor ou contra a qual se pretende argumentar. }\end{array}$ \\
\hline $\begin{array}{l}\text { Generalização ou } \\
\text { extensão }\end{array}$ & $\mathrm{H}$ & $\begin{array}{l}\text { O segundo enunciado exprime uma generalização do fato contido no } \\
\text { primeiro ou uma ampliação da ideia expressa. }\end{array}$ \\
\hline $\begin{array}{l}\text { Especificação ou } \\
\text { exemplificação }\end{array}$ & I & $\begin{array}{l}\text { O segundo enunciado particulariza e/ou exemplifica uma declaração de } \\
\text { ordem mais geral apresentada no primeiro. }\end{array}$ \\
\hline Contraste & $\mathrm{J}$ & $\begin{array}{l}\text { O segundo enunciado apresenta uma declaração que contrasta com a do } \\
\text { primeiro. }\end{array}$ \\
\hline $\begin{array}{l}\text { Correção ou } \\
\text { redefinição }\end{array}$ & $\mathrm{K}$ & $\begin{array}{l}\text { Por meio de um segundo enunciado se corrige, suspende ou redefine o } \\
\text { conteúdo do primeiro, ou se acentua ou reforça o comprometimento com } \\
\text { a verdade do que nele foi veiculado, ou ainda, se questiona a própria } \\
\text { legitimidade da enunciação. }\end{array}$ \\
\hline
\end{tabular}


Conforme salientamos no Capítulo 2, adotamos como unidade de análise os parágrafos, neles verificamos a constituição das orações em cada uma das seções dos artigos (Introdução, Referencial Teórico, Metodologia, Análise de Dados e Considerações Finais/Conclusão). Examinamos a constituição das orações direcionando nossa atenção aos operadores argumentativos que interligam os atos de fala de cada parágrafo, seguindo a ordem em que se apresentam no texto. Selecionamos 245 relações discursivas argumentativas para análise, conforme Tabela 11, sendo 145 relações do artigo 25.65 .2 e 100 relações do artigo 26.67.4, conforme a seguir:

Tabela 11:

Estrutura frástica dos parágrafos dos artigos 25.66 .2 e 26.67 .4 da RC\&F.

\begin{tabular}{|c|c|c|c|c|c|}
\hline & Artigo/seção & 1 & 2 & 3 & 45 \\
\hline Artigc & 25.66 .2 - Introdução & & & & \\
\hline$\S 1^{\mathrm{o}}$ & Oração 1/assim/oração 2 & $\mathrm{~F}$ & & & \\
\hline$\S 2^{\underline{o}}$ & Assim/oração 1/sobretudo/oração 2/bem como & $\mathrm{F}$ & I & A & \\
\hline$\S 3^{0}$ & Oração 1/oração 2/porém/e/oração 3/assim & $\mathrm{C}$ & A & $\mathrm{F}$ & \\
\hline$\S 5^{-}$ & $\begin{array}{l}\text { Oração } 1 \text { /entretanto/além/ oração } 2 \text { / por exemplo/ portanto/desse modo } \\
\text { adicionalmente/oração 3/por }\end{array}$ & $\mathrm{C}$ & A & I & $\mathrm{F} A$ \\
\hline$\S 8^{-}$ & Oração $1 /$ tampouco/ uma vez que/ bem como/ mas & A & $\mathrm{D}$ & A & $\mathrm{C}$ \\
\hline$\S 9^{0}$ & Oração 1/bem como/oração 2/tais como & A & I & & \\
\hline Artig & 25.66.2 - Referencial Teórico - Tópico 2.1 & & & & \\
\hline$\S 1^{\underline{0}}$ & Oração 1/e/oração 2 & A & & & \\
\hline$\S 2^{\underline{o}}$ & Oração 1/oração 2/ oração 3/ oração 4/oração 5/ e/oração 6 & A & & & \\
\hline$\S 3^{\mathrm{o}}$ & Contudo/ oração 1/de acordo/oração 2 / também & $\mathrm{C}$ & $\mathrm{E}$ & A & \\
\hline$\S 4^{\underline{0}}$ & Oração 1/oração 2/em especial/tais como & I & $\mathrm{I}$ & & \\
\hline$\S 5^{\circ}$ & De acordo/oração 1/ oração 2/ assim & $\mathrm{E}$ & $\mathrm{F}$ & & \\
\hline$\S 6^{\mathrm{o}}$ & Oração 1 /oração 2 /por exemplo & I & & & \\
\hline$\S 7^{0}$ & Oração 1/uma vez que/oração 2/portanto & $\mathrm{D}$ & $\mathrm{F}$ & & \\
\hline$\S 10^{\circ}$ & Assim/oração 1 & $\mathrm{~F}$ & & & \\
\hline Artigc & 25.66.2 - Referencial Teórico - Tópico 2.2 & & & & \\
\hline$\S 1^{\underline{0}}$ & De uma maneira geral/oração 1 / contudo/oração $2 /$ tal qual/sobretudo & $\mathrm{H}$ & $\mathrm{C}$ & G & I \\
\hline$\S 2^{\mathrm{o}}$ & Por exemplo/ oração 1 & I & & & \\
\hline$\S 3^{\mathrm{o}}$ & Oração $1 /$ porém & $\mathrm{C}$ & & & \\
\hline$\S 5^{\circ}$ & Oração 1 / oração 2 / tanto ... quanto & $\mathrm{G}$ & & & \\
\hline$\S 6^{-}$ & Oração 1 / porém & $\mathrm{C}$ & & & \\
\hline$\S 7^{0}$ & Por outro lado/ oração 1 & $\mathrm{~J}$ & & & \\
\hline$\S 8^{0}$ & Do mesmo modo/ oração 1/bem como/oração 2 & $\mathrm{G}$ & A & & \\
\hline$\S 9^{0}$ & Oração 1 / oração 2 / tanto ... quanto & $\mathrm{G}$ & & & \\
\hline$\S 10^{\mathrm{o}}$ & Oração 1 / tampouco & $\mathrm{G}$ & & & \\
\hline$\S 11^{\circ}$ & Oração 1/por sua vez/de acordo/embora/além/oração 2 & $\mathrm{C}$ & $\mathrm{E}$ & $\mathrm{C}$ & A \\
\hline$\S 12^{\circ}$ & Oração $1 /$ por outro lado & $\mathrm{J}$ & & & \\
\hline$\S 14^{\circ}$ & Oração $1 /$ também & A & & & \\
\hline$\S 15^{\circ}$ & Oração 1 / oração $2 /$ no entanto & $\mathrm{C}$ & & & \\
\hline$\S 17^{\mathrm{o}}$ & Oração 1/contudo/oração 2/tal qual & $\mathrm{C}$ & $\mathrm{G}$ & & \\
\hline$\S 18^{\circ}$ & Oração $1 /$ por sua vez & $\mathrm{C}$ & & & \\
\hline$\S 19^{\circ}$ & Oração 1/oração 2/entretanto/oração 3 & $\mathrm{C}$ & & & \\
\hline$\S 20^{\circ}$ & Oração $1 /$ pois & $\mathrm{D}$ & & & \\
\hline$\S 21^{\circ}$ & Contudo/ oração 1 /sobretudo/bem como & $\mathrm{C}$ & I & A & \\
\hline Artig & 25.66.2 - Metodologia - Tópico 3.2 & & & & \\
\hline$\S 1^{\circ}$ & Oração $1 /$ de acordo/ oração 2 & $\mathrm{E}$ & & & \\
\hline$\S 3^{0}$ & Oração 1 / oração 2 / oração 3/bem como/ além/assim & A & A & $\mathrm{F}$ & \\
\hline$\S 4^{\underline{0}}$ & Desse modo/oração 1 / bem como/ & A & $\mathrm{A}$ & & \\
\hline
\end{tabular}




\begin{tabular}{|c|c|c|c|c|}
\hline \multicolumn{2}{|r|}{ Artigo/seção } & \multicolumn{3}{|c|}{23} \\
\hline$\S 2^{\underline{o}}$ & Oração 1/ oração 2/ por fim/ oração 3/em outras palavras/ & $\mathrm{F}$ & $\mathrm{D}$ & \\
\hline$\S 3^{-}$ & Oração $1 /$ tal qual & G & & \\
\hline$\S 5^{\circ}$ & Oração 1 / bem como/ conforme/oração $2 /$ de acordo & A & $\mathrm{E}$ & $\mathrm{E}$ \\
\hline$\S 14^{\mathrm{o}}$ & Oração 1 / no entanto/oração 2 & $\mathrm{C}$ & & \\
\hline$\S 19^{\circ}$ & Por fim/ oração $1 /$ & $\mathrm{F}$ & & \\
\hline$\S 21^{\circ}$ & Oração 1/conforme/oração 2 & $\mathrm{E}$ & & \\
\hline \multicolumn{5}{|c|}{ Artigo 25.66.2 - Resultado - Tópico 4.1} \\
\hline$\S 1^{0}$ & Oração 1/em seguida/oração 2 & A & & \\
\hline$\S 3^{0}$ & Oração $1 /$ embora/tanto ... quanto & $\mathrm{C}$ & G & \\
\hline$\S 4^{\circ}$ & Oração 1/oração 2/ embora/além/também & A & A & A \\
\hline$\S 5^{-}$ & Oração 1 /embora & $\mathrm{C}$ & & \\
\hline$\S 6^{\mathrm{o}}$ & Oração 1 / haja vista & $\mathrm{D}$ & & \\
\hline$\S 7^{0}$ & Oração 1/no entanto/outrossim/oração 2 & $\mathrm{C}$ & A & \\
\hline$\S 9^{-}$ & Oração 1/conforme/entretanto/oração 2 & $\mathrm{E}$ & $\mathrm{C}$ & \\
\hline$\S 11^{\mathrm{o}}$ & Oração 1 /conforme & $\mathrm{E}$ & & \\
\hline$\S 12^{\mathrm{o}}$ & Oração $1 /$ tal qual/oração 2 & $\mathrm{G}$ & & \\
\hline$\S 14^{\circ}$ & Oração $1 /$ conforme/entretanto/oração 2 & $\mathrm{E}$ & $\mathrm{C}$ & \\
\hline$\S 15^{\circ}$ & Oração 1/haja vista/oração 2/oração 3/porém/oração 4/oração 5 & $\mathrm{D}$ & $\mathrm{C}$ & \\
\hline$\S 16^{0}$ & Oração 1/entretanto/oração 2/oração 3 & $\mathrm{C}$ & & \\
\hline$\S 17^{\circ}$ & Oração 1/contudo/oração 2/oração 3 & $\mathrm{C}$ & & \\
\hline$\S 19^{\underline{o}}$ & Assim/oração 1/do mesmo modo/oração 2/oração 3/assim & $\mathrm{F}$ & G & $\mathrm{F}$ \\
\hline$\S 21^{\mathrm{o}}$ & Oração 1/oração 2/assim/oração 3 & $\mathrm{~F}$ & & \\
\hline$\S 22^{\underline{o}}$ & Por oportuno/oração 1 & $\mathrm{D}$ & & \\
\hline$\S 23^{\circ}$ & Por fim/de uma maneira geral/oração 1/dessa forma/oração 2 & $\mathrm{~F}$ & $\mathrm{H}$ & $\mathrm{F}$ \\
\hline \multicolumn{5}{|c|}{ Artigo 25.66.2 - Resultado - Tópico 4.2} \\
\hline$\S 1^{\underline{0}}$ & Oração $1 /$ tanto ... quanto/conforme & G & $\mathrm{E}$ & \\
\hline$\S 3^{\underline{o}}$ & Contudo/oração 1/ embora & $\mathrm{C}$ & $\mathrm{C}$ & \\
\hline$\S 5^{0}$ & Oração 1 /no entanto/oração 2 & $\mathrm{C}$ & & \\
\hline$\S 7^{0}$ & Oração 1 / por outro lado/oração 2 & $\mathrm{~J}$ & & \\
\hline$\S 8^{\circ}$ & Oração $1 /$ pelo contrário & $\mathrm{J}$ & & \\
\hline \multicolumn{5}{|c|}{ Artigo 25.66.2-Resultado - Tópico 4.3} \\
\hline$\S 2^{-}$ & Oração 1 /no entanto/oração 2 & $\mathrm{C}$ & & \\
\hline$\S 3^{0}$ & Oração 1/entretanto/oração 2/oração 3 & $\mathrm{C}$ & & \\
\hline$\S 4^{\mathrm{o}}$ & Oração 1/entretanto/oração2/ assim/oração 3 & $\mathrm{C}$ & $\mathrm{F}$ & \\
\hline$\S 5^{\circ}$ & Oração 1/bem como/oração 2 & A & & \\
\hline$\S 6^{\mathrm{o}}$ & Oração 1/contudo/oração 2/tanto ... quanto/oração 3 & $\mathrm{C}$ & G & \\
\hline$\S 8^{-}$ & Por outro lado/oração $1 /$ a exemplo/ no entanto/oração $2 /$ tais como & $\mathrm{J}$ & I & C I \\
\hline$\S 9^{-}$ & Por fim/oração 1 & $\mathrm{~F}$ & & \\
\hline$\S 10^{\circ}$ & Oração 1 /conforme/oração 2/uma vez que & $\mathrm{E}$ & $\mathrm{D}$ & \\
\hline$\S 11^{\circ}$ & Oração 1/bem como/entretanto/oração 2 & A & $\mathrm{C}$ & \\
\hline \multicolumn{5}{|c|}{ Artigo 25.66.2 - Considerações Finais } \\
\hline$\S 1^{0}$ & Oração 1/oração 2/adicionalmente/oração 3 & A & & \\
\hline$\S 2^{-}$ & Oração 1/oração 2/ por fim/oração 3 & $\mathrm{~F}$ & & \\
\hline$\S 3^{\underline{o}}$ & Oração 1 / oração 2 /embora/tanto ... quanto/uma vez que/oração 3 & $\mathrm{C}$ & $\mathrm{G}$ & $\mathrm{D}$ \\
\hline$\S 4^{-}$ & Oração 1/apesar de /oração 2/além/oração 3/ & $\mathrm{J}$ & A & \\
\hline$\S 6^{\mathrm{o}}$ & Por outro lado/oração 1/ mesmo que/ assim/oração 3 & $\mathrm{~J}$ & $\mathrm{D}$ & $\mathrm{F}$ \\
\hline$\S 70$ & Outrossim/oração 1/ ao invés/ tal qual/uma vez que/assim & A & $\mathrm{J}$ & G D F \\
\hline$\S 8^{0}$ & Contudo/oração 1/ainda /oração 2/oração 3/apesar de & $\mathrm{C}$ & A & $\mathrm{J}$ \\
\hline$\S 9^{\underline{0}}$ & Oração 1/além/uma vez que/oração 3 & A & $\mathrm{D}$ & \\
\hline$\S 10^{-}$ & Oração 1/por sua vez/oração 2 & $\mathrm{C}$ & & \\
\hline \multicolumn{5}{|c|}{ Artigo 26.67.4 - Introdução - Tópico 1} \\
\hline$\S 1^{\underline{0}}$ & Oração 1/de maneira geral/oração 2/ tais como/oração 3/oração 4/ou seja/oração 5 & $\mathrm{H}$ & I & $\mathrm{D}$ \\
\hline$\S 3^{\underline{o}}$ & Oração 1/ assim/oração 2/em outras palavras/oração 3 & $\mathrm{~F}$ & $\mathrm{D}$ & \\
\hline$\S 6^{-}$ & $\begin{array}{l}\text { Adicionalmente/oração1/apesar de/oração 2/oração 3/no entanto/oração 4/oração 5/bem } \\
\text { como/oração } 6\end{array}$ & A & $\mathrm{J}$ & $\mathrm{CA}$ \\
\hline$\S 7^{\circ}$ & Oração 1/por sua vez/oração 2/no entanto/ oração 3/oração 4 & $\mathrm{C}$ & $\mathrm{C}$ & \\
\hline$\S 9^{0}$ & Oração 1/oração 2/também/oração 3 & A & & \\
\hline$\S 10^{\mathrm{o}}$ & Assim/oração 1/oração 2 & $\mathrm{~F}$ & & \\
\hline$\S 11^{\mathrm{o}}$ & Oração 1/para tanto/oração 2/oração 3 & $\mathrm{D}$ & & \\
\hline
\end{tabular}




\begin{tabular}{|c|c|c|c|c|}
\hline \multicolumn{2}{|r|}{ Artigo/seção } & & \multirow{2}{*}{$\begin{array}{l}2 \\
\mathrm{~F}\end{array}$} & 345 \\
\hline$\S 12^{\underline{0}}$ & Oração1/adicionalmente/oração 2/por fim/oração 3/mas & & & \\
\hline$\S 13^{0}$ & Além/oração 1/oração 2/oração 3/oração 4/e/por fim/oração 5 & A & A & $\mathrm{F}$ \\
\hline \multicolumn{5}{|c|}{ Artigo 26.67.4 - Referencial Teórico - Tópico 2} \\
\hline$\S 1^{\underline{0}}$ & Oração 1/oração 2/pois/oração 3 & $\mathrm{D}$ & & \\
\hline$\S 2^{-}$ & Oração 1/oração 2/ também/oração 3 & A & & \\
\hline$\S 3^{0}$ & Assim /oração 1/ em outras palavras/oração 2 & $\mathrm{~F}$ & $\mathrm{D}$ & \\
\hline$\S 4^{0}$ & Oração 1/oração 2/tais como/oração 3/ oração 4/ oração 5/ oração 6 & $\mathrm{D}$ & & \\
\hline$\S 5^{-}$ & Oração 1/de acordo/ oração 2 & $\mathrm{E}$ & & \\
\hline$\S 6^{-}$ & Oração 1/tais como/oração 2 & $\mathrm{D}$ & & \\
\hline$\S 7^{0}$ & Tais como/ oração 1 & $\mathrm{D}$ & & \\
\hline$\S 8^{\underline{0}}$ & Oração $1 /$ e/ oração 2 & A & & \\
\hline \multicolumn{5}{|c|}{ Artigo 26.67.4 - Metodologia - Tópico 3} \\
\hline$\S 4^{\underline{0}}$ & Oração 1/no entanto/oração 2/oração 3/oração 4 & $\mathrm{C}$ & & \\
\hline$\S 5^{\mathrm{o}}$ & Oração 1/por exemplo/oração 2 / oração 3/ou seja/oração 4 & I & $\mathrm{D}$ & \\
\hline$\S 7^{0}$ & Oração 1 /porém/ oração 2/oração 3 & $\mathrm{C}$ & & \\
\hline$\S 8^{\underline{o}}$ & Oração 1/também/oração 2/oração 3/oração 4/oração 5/segundo/oração 6 & A & $\mathrm{E}$ & \\
\hline$\S 12^{\underline{o}}$ & Oração 1/oração 2/bem como/oração 3 & A & & \\
\hline$\S 13^{0}$ & Oração 1 /por tais/oração $2 /$ por exemplo/oração $3 /$ tanto como & $\mathrm{D}$ & I & G \\
\hline$\S 14^{\mathrm{o}}$ & Além/oração 1/ além /oração 3/oração 4 & A & A & \\
\hline$\S 15^{\circ}$ & Oração 1 /portanto/ oração 2/ & $\mathrm{C}$ & & \\
\hline$\S 16^{\mathrm{o}}$ & Oração 1/oração 2/assim/oração 3/oração 4/adicionalmente/oração 5 & $\mathrm{~F}$ & A & \\
\hline$\S 20^{\circ}$ & Oração 1/porém/oração 2/oração 3/assim/oração 4 & $\mathrm{C}$ & $\mathrm{F}$ & \\
\hline$\S 21^{\mathrm{o}}$ & Oração 1/porém/oração 2/porém/oração 3/ visto que/ & $\mathrm{C}$ & $\mathrm{C}$ & $\mathrm{D}$ \\
\hline$\S 22^{\underline{o}}$ & Por fim/ oração 1/ segundo/ oração 2/ além/oração 3 & $\mathrm{~F}$ & $\mathrm{C}$ & A \\
\hline \multicolumn{5}{|c|}{ Artigo 26.67.4 - Metodologia - Tópico 4.2} \\
\hline$\S 4^{\mathrm{o}}$ & Assim/oração 1/oração2 & $\mathrm{F}$ & & \\
\hline$\S 5^{\circ}$ & Assim/oração 1/oração 2/oração 3 & $\mathrm{~F}$ & & \\
\hline$\S 6^{-}$ & Por fim/ oração 1 / oração 2 & $\mathrm{~F}$ & & \\
\hline \multicolumn{5}{|c|}{ Artigo 26.67.4 - Metodologia - Tópico 4.3} \\
\hline$\S 9^{\circ}$ & Oração 1/além/oração 2/oração 3 & A & & \\
\hline$\S 11^{\underline{o}}$ & Oração 1/assim/oração 2/e/portanto/oração 3 & $\mathrm{~F}$ & A & $\mathrm{F}$ \\
\hline$\S 19^{\mathrm{o}}$ & Oração 1/oração 2/uma vez que/oração 3 & $\mathrm{D}$ & & \\
\hline$\S 20^{\circ}$ & Por fim/oração 1/portanto/oração 2 & $\mathrm{~F}$ & $\mathrm{~F}$ & \\
\hline \multicolumn{5}{|c|}{ Artigo 26.67.4-Resultado - Tópico 5} \\
\hline$\S 3^{0}$ & De acordo & $\mathrm{E}$ & $\mathrm{D}$ & $\mathrm{C}$ \\
\hline$\S 4^{0}$ & Oração $1 /$ conforme & $\mathrm{E}$ & & \\
\hline$\S 5^{0}$ & De acordo/oração 1/oração 2/ oração 3/bem como/oração 4/ assim/oração 5 & $\mathrm{E}$ & A & $\mathrm{D}$ \\
\hline$\S 6^{\mathrm{o}}$ & Oração 1 /ou seja/oração 2 & $\mathrm{D}$ & & \\
\hline$\S 7^{\underline{0}}$ & Oração 1/adicionalmente/oração 2/ainda/oração 3/visto que/oração 4 & A & A & $\mathrm{D}$ \\
\hline$\S 8^{0}$ & Oração 1/de acordo/oração 2/logo/oração 3/portanto/oração 4 & $\mathrm{E}$ & $\mathrm{F}$ & $\mathrm{F}$ \\
\hline$\S 9^{\underline{0}}$ & Com isso/oração 1/ou seja/oração 2/oração 3 & A & $\mathrm{D}$ & \\
\hline$\S 11^{\mathrm{o}}$ & De acordo/oração $1 /$ tanto ... quanto/oração 2/logo/oração 3/portanto/oração 4 & $\mathrm{E}$ & G & $\mathrm{F} F$ \\
\hline$\S 12^{\underline{o}}$ & Em seguida/oração 1/ademais/oração 2 & A & A & \\
\hline$\S 13^{\circ}$ & Adicionalmente/oração 1/bem como/oração 2/oração 3/oração 4 & A & A & \\
\hline \multicolumn{5}{|c|}{ Artigo 26.67.4 - Considerações Finais - Tópico 6} \\
\hline$\S 1^{\mathrm{o}}$ & Oração 1/oração 2/assim/oração 3 & $\mathrm{~F}$ & & \\
\hline$\S 2^{\underline{o}}$ & Oração 1/para tanto/ oração 2/oração 3 & A & & \\
\hline$\S 3^{0}$ & Oração 1/pois/oração 2/adicionalmente/oração 3 & $\mathrm{D}$ & A & \\
\hline$\S 4^{\circ}$ & Oração 1/ademais/ oração 2/ dessa forma/oração3 & A & $\mathrm{D}$ & \\
\hline$\S 5^{\mathrm{o}}$ & Oração 1/assim/oração 2/mas/oração 3/bem como/oração 4/oração 5/contudo/oração 6 & $\mathrm{~F}$ & $\mathrm{C}$ & $\mathrm{A} \mathrm{C}$ \\
\hline$\S 6^{-}$ & De forma geral/oração 1/ou seja/oração 2/oração 3 & $\mathrm{H}$ & $\mathrm{D}$ & \\
\hline$\S 7^{0}$ & Ademais/oração 1/bem como/oração 2 & A & A & \\
\hline
\end{tabular}

Dada à amplitude das informações e a necessidade de obtermos uma síntese que reflita a predominância argumentativa do artigo nas estruturas fráticas (orações e conectores argumentativos) e as respectivas codificações dos operadores argumentativos examinados 
(Tabela 10), sumarizamos as classificações/codificações dos 145 operadores argumentativos que destacamos na Figura 16. Desenvolveremos a análise de cada tipo de operador argumentativo em função da sua predominância no discurso tomando, como referência o artigo 25.66.2, e iniciando pelos maiores percentuais, ou seja, do mais predominante ao menos predominante no texto do artigo.

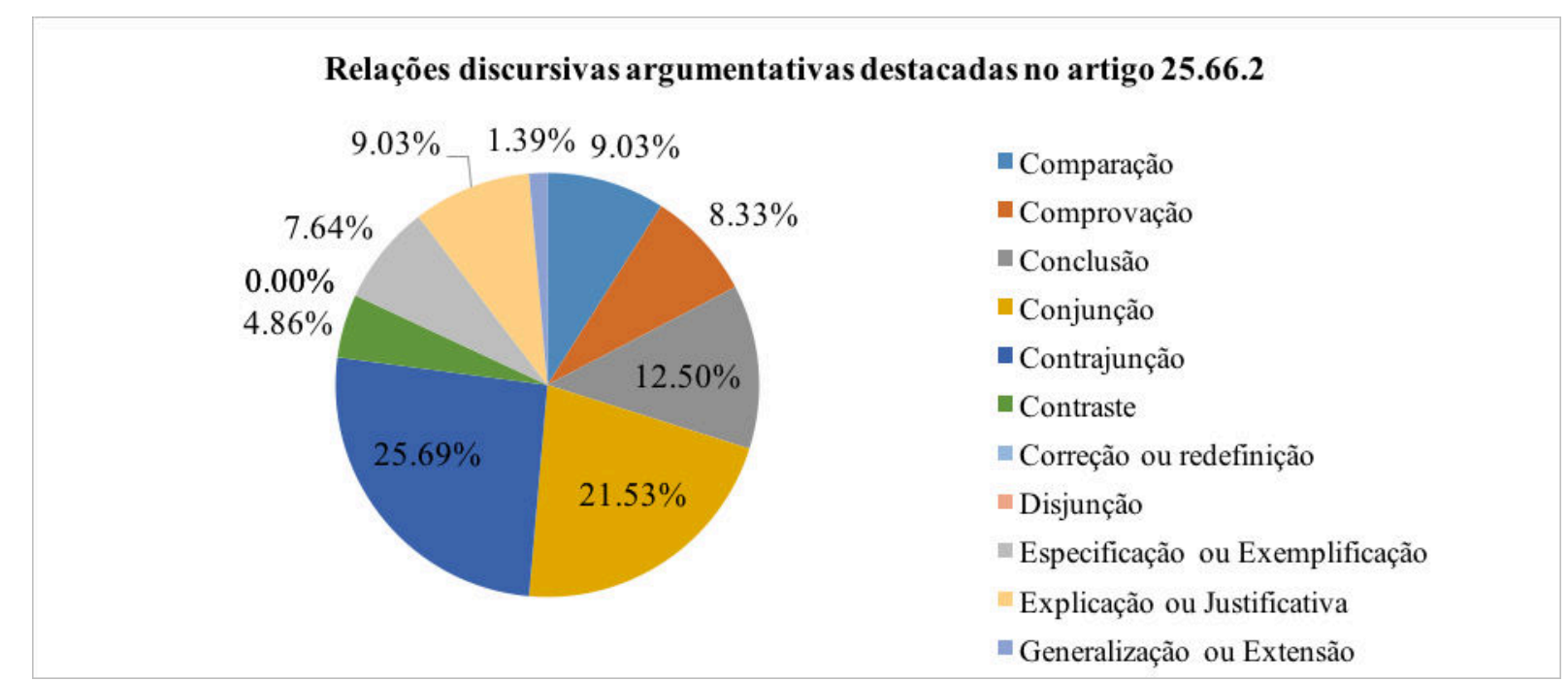

Figura 15. Composição do artigo 25.66.2 a partir da análise dos operadores argumentativos de Koch (2010).

A partir da Figura 15, podemos inferir que o artigo 25.66.2 apresenta uma tessitura discursiva fundamentada em contrajunção/contraste, conjunção/adição e conclusão/fechamentos parciais de ideias - 25,69\%; 21,53\% e 12,50\% respectivamente. Entendemos que estes são os argumentos principais e que a combinação destes três operadores argumentativos empregados tem potencialidade para construir um texto reflexivo e provocativo, principalmente por se tratar de um texto científico. Entendemos, ainda que, os encadeadores que estabelecem comparações, explicações, justificativas, comprovações, exemplos e especificações neste caso são acessórios, portanto, geralmente apoiam as ideias principais introduzidas pelos operadores que se destacam na Figura 16 (contraposição, conjunção e conclusão). Ademais, identificamos que os autores se utilizam timidamente de encadeadores de generalizações e contraste e não se utilizam da prerrogativa da correção/redefinição e/ou de provocação, tampouco tentam demover o consumidor do texto de uma opinião inicial (disjunção) - não há o emprego de argumentos deste gênero no texto.

Vejamos como ocorre no artigo 26.67.4, no qual selecionamos 100 operadores de argumentação e sumarizados por meio da Figura 16, a seguir: 


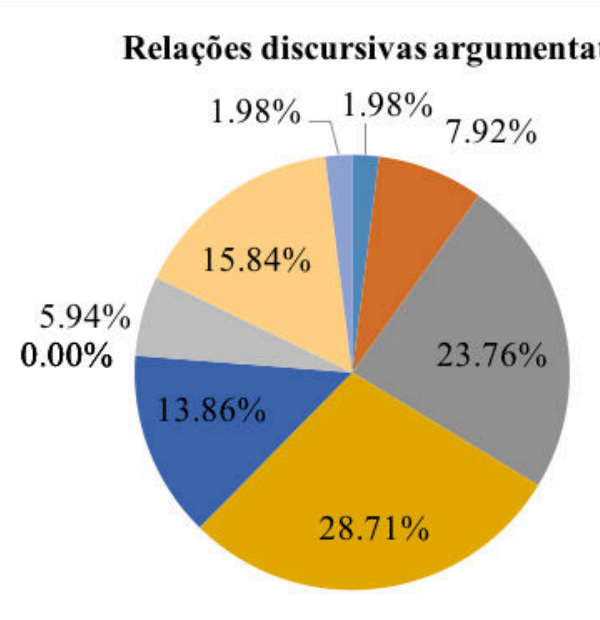

Relações discursivas argumentativas destacadas no artigo 26.67.4

- Comparação

- Comprovação

- Conclusão

- Conjunção

- Contrajunção

- Contraste

ఐ Correção ou redefinição

- Disjunção

Especificação ou Exemplificação

Explicação ou Justificativa

- Generalização ou Extensão

Figura 16. Composição do artigo 26.67.4 a partir da análise dos operadores argumentativos de Koch (2010).

A partir da Figura 16 entendemos que o artigo 26.67.4 produz discurso cuja tessitura se alicerça em argumentos de conjunção/adição, conclusão/fechamentos parciais e contrajunção/contrastes, obedecendo esta ordem de gradativa de utilização - 28,71\%; 23,76\% e $15,84 \%$ respectivamente. Da mesma forma que no artigo 25.66.2, evidenciamos a exploração destes argumentos como fundamentais a retórica, utilizados pelos autores para conduzir o consumidor do texto aos seus pensamentos. Da mesma maneira que no artigo anterior, podemos afirmar que os operadores utilizados têm potencialidade compor um texto reflexivo e provocativo, que faz uso dos encadeadores de explicações, justificativas, comprovações, exemplos e especificações para sustentar ideias e aclarar assertivas. Os autores do artigo 26.67.4 também se utilizam em menor proporção de correção ou redefinição e comparação. Não evidenciamos no texto o uso de argumentos de contraste, disjunção ou generalização.

As considerações decorrentes das Figuras 16 e 17 nos permitem perceber que os autores se utilizam, fundamentalmente, dos mesmos tipos de operadores para gerar coesão e dar fluidez à discussão que constroem - contrajunção, conjunção e conclusão. Acreditamos que esses operadores são centrais nestes textos porque alicerçam e consolidam o discurso científico, enquanto que os outros operadores utilizados no texto giram em torno desses, favorecendo a compreensão e a adesão às concepções que os autores defendem. Ademais, apesar das regras impostas ao texto de um artigo científico, pensamos que a tessitura do discurso é bastante peculiar à estratégia de persuasão dos autores, bem como à subjetividade dos indivíduos vinculada à maneira de conceber e reproduzir o seu discurso. Esta ideia foi explorada por Fairclough (2008) ao relatar sobre a capacidade que os discursos têm de afetar os sujeitos de maneira inconsciente, criando uma falsa ideia de que os mesmos são fontes de 
sentido e escamoteando a dominação institucionalizada por grupos que detêm o poder.

Vale destacar que, o emprego dos operadores argumentativos nos textos dos artigos não guarda a mesma proporção - no artigo 25.66 .2 temos contrajunção, conjunção e conclusão como ordem hierárquica de uso, enquanto que no artigo 26.67.4 temos conjunção, conclusão e contrajunção como ordem hierárquica de uso.

Todavia, em nossa concepção, a interpretação construída a partir dos números que os gráficos evidenciam não é suficiente para sustentar a coerência semântica dos argumentos utilizados. Desta maneira, optamos por realizar uma análise sobre o uso dos operadores argumentativos explorados pelos autores nos atos de fala, tomando como unidade de análise o parágrafo. Trataremos agora de maneira detalhada sobre as relações argumentativas que compõe o texto de cada um dos artigos.

No artigo 25.66.2 pudemos evidenciar que 25,69\% são compostas por operadores de contrajunções, aqueles que geralmente introduzem as frases adversativas, ou seja, atos de fala que apresentam concepções distintas. Os encadeadores adversativos/contrajunção oportunizam a confrontação de ideias contrastantes acerca de um mesmo assunto/fato, sempre que esta ocorre há prevalência do enunciado introduzido pelo operador de adversidade.

Ao considerarmos os operadores argumentativos selecionados, podemos perceber que a estratégia de argumentação predominantemente utilizada pelos autores dos artigos e 25.66 .2 e 26.67.4 fundamentam-se em encadeadores diferentes. A Tabela 12, a seguir, apresenta os operadores de contrajunção empregados nos artigos 25.66 .2 e 26.67 .4 que selecionamos para análise:

Tabela 12:

Ocorrências de operadores argumentativos de contrajunção por artigo

\begin{tabular}{lcccccr}
\hline & Operador & \multicolumn{2}{c}{ Artigo 25.66.2 } & \multicolumn{2}{c}{ Artigo 26.67.4 } & \multicolumn{2}{c}{ Total } \\
\cline { 2 - 7 } & Ocorrência & \% & Ocorrência & \% & Ocorrência & \% \\
\hline Apesar de & 2 & 5,41 & 1 & 7,14 & 3 & 5,88 \\
Contudo & 8 & 21,62 & 1 & 7,14 & 9 & 17,65 \\
Embora & 6 & 16,22 & 0 & 0,00 & 6 & 11,76 \\
Entretanto & 8 & 21,62 & 0 & 0,00 & 8 & 15,69 \\
Mas & 1 & 2,70 & 2 & 14,29 & 3 & 5,88 \\
No entanto & 6 & 16,22 & 4 & 28,57 & 10 & 19,61 \\
Por sua vez & 2 & 5,41 & 1 & 7,14 & 3 & 5,88 \\
Porém & 4 & 10,81 & 5 & 35,71 & 9 & 17,65 \\
Total & 37 & 100,00 & 14 & 100,00 & 51 & 100,00 \\
\hline
\end{tabular}

A partir da Tabela 12 podemos identificar que os operadores argumentativos de contrajunção mais utilizados no artigo 25.66 .2 são "entretanto" e "contudo" (21,62\% cada), "no entanto" e "embora" (16,22\% cada), seguidos de "porém" (10,81\%), Apesar de e "por sua vez" (5,41\% cada) e "mas" (2,70\%). Já no artigo 26.67 .4 temos que "porém" foi a 
contrajunção mais utilizada (35,71\%), seguida de "no entanto" (28,57\%), "mas" (14,29\%) e "contudo", "apesar de" e "por sua vez" (7,14\% cada). Considerando os dois artigos temos que a adversativa mais comumente empregada é "no entanto" equivalendo a 19,61\% dos argumentos de contrajunção/adversidade (10 dentre as 51 ocorrências desse tipo de operador nos textos dos artigos).

Destaquemos aqui o uso de duas adversativas na Introdução do artigo 25.66 .2 que se utilizam dos conectivos "porém" e "entretanto", as quais fazem referência a estudos anteriores usados para delimitação da lacuna da investigação: "algumas pesquisas, sob diversas perspectivas, foram desenvolvidas nesse sentido, porém os resultados obtidos ainda são divergentes" [grifo nosso] (Tópico $1, \S 3^{\circ}$, p. 229). Nesta frase, o que notamos é que essa adversativa estabelece uma contraposição entre ideias internas ao texto e não a ideias expressas em outros textos de outros autores com perspectivas diferentes do autor deste artigo. Ademais, na adversativa "porém" a contraposição parece como ideia adjacente de que pesquisas realizadas sobre perspectivas diferentes levariam a resultados não divergentes.

Numa outra adversativa do artigo 25.66 .2 (Tópico $1, \S 5^{\circ}$, p. 229) que também faz alusão a pesquisas anteriormente realizadas, temos o seguinte trecho: "a investigação aqui desenvolvida contemplou a capacidade associativa e a tempestividade informacional do lucro contábil. Entretanto, além desses dois aspectos, pesquisas têm sugerido que o conservadorismo; a existência de poucas oportunidades para o gerenciamento de resultados" [grifo nosso]. Neste caso, "entretanto" refere-se a uma contraposição que se faz ao número de aspectos contemplados na própria pesquisa do autor. Primeiro ele informa que se dedicou a dois aspectos e, em seguida, informa que outros autores apontam outros aspectos dentre os quais ele toma um e acrescenta aos outros dois que havia anunciado anteriormente.

No Tópico 2.1 do artigo 25.66 .2 temos que os autores se utilizam da conjunção adversativa "contudo" para introduzir o $\S 3^{\circ}$ e se contraporem aos achados de Ball (2006) citado no $\S 2^{\circ}$. Os autores buscam estabelecer uma argumentação com intenção de contraposição de ideias, todavia entendemos que o emprego da contrajunção é inoportuno uma vez que em nenhum momento Ball (2006) afirma que 'a adoção dos IFRS aumenta a relevância da informação contábil' - contraponto apresentado pelos autores. Incluso, se retirássemos a adversativa da frase não haveria perda comunicativa do ato de fala. Destacamos, ainda, que no parágrafo $\S 2^{\circ}$ temos a apresentação de vantagens decorrentes da adoção do IFRS, e em nenhum instante os autores afirmam que ela é condição única para garantir a relevância informacional.

Desta maneira, o uso de um argumento de concessão, em substituição ao 
contraste/adversidade que os autores buscam evidenciar, traria maior fidelidade de sentido ao discurso já que na concessão há uma subordinação do segundo ato de fala que não se constitui em obstáculo/impedimento do ato de fala principal.

Ainda no Referencial Teórico do artigo 25.66.2 (Tópico 2.2, $\S 6^{\circ}$, p. 230) temos “Ahmed, Chalmers, e Khlif (2013) constataram, de uma maneira generalizada, um aumento na associação (value relevance) entre o lucro contábil e o preço das ações, porém verificaram que o nível de associação apresentado pelo patrimônio líquido não sofreu alterações. . ." [grifo nosso]. Da mesma maneira que observado anteriormente o operador adversativo "porém" também não traduz contraposição de ideias externas, percebemos que a intenção é fazer um contraponto em relação aos achados do mesmo autor, mas, ainda assim, não há sentido de contraposição argumentativa. Acontece que o ato de fala iniciado pelo operador "porém" introduz um resultado de pesquisa que é discrepante dos anteriores no que diz respeito à relação entre as variáveis estudadas - enquanto nas primeiras ocorreu um aumento na última não houve alteração.

Ao analisarmos o empregado do operador "porém", no artigo 25.66.2 (Tópico 2.2, § $6^{\circ}$, p. 230), entendemos que este retrata uma particularidade no comportamento das variáveis e não contraste por adversidade de concepção acerca das variáveis em si - enquanto houve aumento da associação do "lucro contábil" e "preço das ações" a variável "patrimônio líquido" não apresentou qualquer mutação comportamental. Podemos estender essa interpretação ao termo "contudo" empregado pelos autores no início do Tópico 4.2, § 3º , p. 237 da Análise de Resultados, cuja intenção é de contrapor o ato da fala do parágrafo anterior:

Contudo, a análise segregada demonstrou que isso, necessariamente, não é verdadeiro, pois, muito embora as estimações para os períodos de transição e pós IFRS tenham apresentado elevado poder explicativo, somente foi possível verificar significância para o coeficiente de $\mathrm{R}_{\mathrm{it}}$ no período pré IFRS. [grifo nosso].

Em nossa opinião se retirarmos o operador argumentativo "contudo" ou substituíssemos uma expressão que evidenciasse destaque como "ressaltamos" não haveria mudança de sentido do ato de fala. Da mesma maneira que acontece no conectivo "no entanto" no Tópico 2.2 ( $\left(15^{\circ}\right.$, p. 231): "não foram encontradas evidências de reações anormais do preço das ações em resposta a divulgação dos lucros contábeis pós IFRS, no entanto os resultados sugerem que a adoção desses padrões teria aprimorado a relevância informacional do lucro contábil" [grifo nosso], neste caso nosso posicionamento também é de que não há contraponto, e que o um conectivo de conjunção traria sentido a frase sem causarlhe ruído semântico. Concebemos que os autores evidenciam oposição entre ideias internas ao 
texto decorrentes do mesmo resultado de pesquisa e não opiniões de resultados de autores distintos.

Destaquemos também o ato de fala do artigo 25.66 .2 que constitui o $\S 8^{\circ}$, p. 239 do Tópico 4.3 da análise de resultados:

Por outro lado, frise-se que parte desses resultados contraria aqueles obtidos por uma série de estudos realizados no Brasil, a exemplo de Costa, Costa e Lopes (2006), Coelho e Lima (2007), Santos e Costa (2008) e Almeida, Scalzer, e Costa (2008). No entanto, as divergências metodológicas existentes, tais como técnicas estatísticas empregadas, tamanho da amostra, período etc., são aspectos que devem ser considerados. [grifo nosso].

Apesar do termo "no entanto" denotar adversidade, nesta frase nos causa estranheza considerá-lo como contraponto, visto que no primeiro ato de fala tem-se uma assertiva que trata acerca de um paralelo entre os resultados da pesquisa realizada no próprio artigo 25.66.2 com aqueles outros resultados de pesquisa encontrados por outros autores em outras investigações: "[...] frise-se que parte desses resultados contraria aqueles obtidos por uma série de estudos realizados no Brasil". Em seguida, os autores complementam "[...] no entanto, as divergências metodológicas existentes, tais como técnicas estatísticas empregadas, tamanho da amostra, período etc., são aspectos que devem ser considerados". Ou seja, os autores trazem uma observação adicional, a qual, em nossa interpretação, não corresponde a uma adversidade. O operador "no entanto" não guarda sentido de contraposição e se fosse substituído pelo termo "ressalta-se que" a frase teria, em nossa opinião, maior fidelidade de significação. 'Os resultados contrariam' não é afirmação adversativa de 'existirem divergências metodológicas', desta maneira, trata-se do uso inadequado do termo que compromete o rigor do significado atribuído a esse discurso e pode causar ruídos de comunicação ao consumidor final desse texto.

Identificamos replicação das situações descritas no Referencial Teórico Tópico 2.1 ( $§$ $3^{\underline{0}}$, p. 299), Tópico $2.2\left(\S 1^{\underline{o}}\right.$, p. 230) e ( $\left(21^{\underline{o}}\right.$, p. 231); na metodologia Tópico $3.3\left(\S 14^{\underline{o}}\right.$, p.

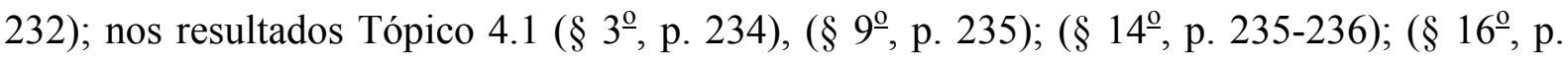
236) e Tópico 4.2 ( $§ 3^{\circ}$ e $\S 4^{\circ}$, p. 237), conforme Apêndice D.

Já no Tópico 2.2 ( $\$ 17^{\circ}$, p. 231), ainda do artigo 25.66.2, entendemos temos emprego do termo de contraposição "contudo" de forma coerente ao seu sentido uma vez que o mesmo apresenta a posicionamento distinto de diferentes de autores em relação ao mesmo assunto: Costa (2012) e Lima (2010). Costa (2012) afirma que após a adoção do IFRS no Brasil "[...] houve redução da conformidade financeira e fiscal", em Lima (2010) temos que "a evidência de associação entre o lucro contábil pós-convergência e o retorno das ações (value 
relevance)".

Passemos à análise das contrajunções no artigo 26.67.4 a partir do de fala destacado a seguir:

Adicionalmente, a Lei 11.638/07 introduziu a obrigatoriedade da divulgação da Demonstração do Valor Adicionado (DVA) para as companhias abertas, que até a aprovação da referida Lei ainda não era exigida no Brasil, apesar de algumas empresas a divulgarem de maneira voluntária. Destaca-se que esse demonstrativo não é contemplado nas normas internacionais de contabilidade, emitidas pelo International Accounting Standards Board (IASB). No entanto, vale salientar que o Global Reporting Initiative (GRI) considera como indicador de desempenho o Valor Econômico Gerado e Distribuído (EVG\&D), indicador muito próximo ao valor adicionado, apresentado na DVA, diferindo, principalmente, pela inclusão no valor econômico distribuído dos investimentos na comunidade, que incluem as contribuições voluntárias e investimentos de fundos na comunidade como um todo.[grifo nosso]. (Tópico $1, \S 6^{\circ}$, p. 58).

Os autores se utilizam do termo "apesar de" para evidenciar uma contradição referente à ideia de que 'não sendo obrigatória' a DVA é 'divulgada voluntariamente por algumas empresas', neste caso entendemos que o operador "apesar de" não evidencia uma contraposição, mas uma concessão dado que o segundo ato de fala não anula o primeiro. No que se refere ao termo "no entanto", entendemos que os autores o utilizaram com propriedade para exprimir a opinião de duas entidades normatizadoras de relevância no âmbito internacional, mostrando que há uma discrepância de concepção ideológica sobre a exigência de publicação de demonstrativos relacionados à evidenciação de aspectos sociais. Mais adiante essa concepção é ratificada com outra adversativa quando os autores enfatizam que os aspectos sociais não fazem parte dos interesses de pesquisa na área, vejamos:

Reconhece-se que questões sociais podem influenciar a contabilidade e que esta, por sua_vez, pode mobilizar e mudar o comportamento do usuário. No entanto, essas interações têm sido pouco investigadas. A relação da contabilidade com o social tende a ser indicada e presumida e não descrita e analisada (Burchell, Clubb, \& Hopwood, 1985).[Grifo nosso].(Tópico 1, § 7ํㅜ p.58).

"No entanto" no ato de fala anteriormente evidenciado aparece entre duas orações que, em nossa opinião, se complementam e não se contrapõe - são duas características relativas à contabilidade social 'capacidade de influenciar' e 'pouco investigada'. O 'poder influenciar a contabilidade e mudar o comportamento do usuário' não é contraposição de ‘interações pouco investigadas'. $\mathrm{O}$ ato de fala introduzido pela contrajunção é uma estratégia dos autores para justificar a investigação que estão realizando, a qual não vai de encontro com o ato de fala anterior. Em nossa opinião, um argumento de conjunção imprimiria clareza e aderência à intenção de apresentar a justificativa para a lacuna de pesquisa que se pretende preencher. Parece-nos que o uso de "no entanto" funciona aqui mais para criar uma imagem de texto argumentativo do que para criar uma argumentação do tipo em que posicionamentos são, de 
fato, contrapostos.

Tomando como exemplo o uso do termo "porém" no artigo 26.67.4 (Tópico 3, § 7º , p. 60) entendemos que os autores têm a pretensão de apresentar uma contraposição alicerçada no poder informativo que os demonstrativos financeiros podem oferecer, conforme a seguir:

As informações utilizadas na DVA são, normalmente, extraídas da Demonstração do Resultado do Exercício (DRE). No entanto, não apresentam objetivos semelhantes, mas complementares. A DRE tem por prioridade enfatizar o lucro líquido, que, na DVA, corresponde à parcela do valor adicionado destinada aos detentores do capital.

O exame do texto nos faz compreender que não há contraposição, e sim, mais uma concessão. Incluso, os próprios autores exprimem que os demonstrativos são complementares, assim não há um contraponto entre as concepções e não há uma argumentação contrapositiva de acordo com o sentido de Koch (2010). Ainda no artigo 26.67 .4 (Tópico 6, § 5ํㅜ p.67) verificamos um argumento de contraposição adversativa que entendemos guardar conformidade semântica, visto que, apresenta a contraposição de ideias de autores acerca de um mesmo assunto, vejamos:

Assim, presume-se que o mercado espera das empresas não apenas a remuneração do capital próprio, mas, principalmente, a geração de riqueza que possa garantir a viabilidade futura, bem como remunerar todos os que se esforçam para a geração de riqueza. Supõe-se, também, que o mercado pode estar considerando a responsabilidade social da empresa, também evidenciada na DVA. O resultado corrobora os estudos de Scherer (2006) e de Crippa e Coelho (2012). Contudo, vão de encontro com os achados de Barros et al. (2013) e Martins et al. (2014).

Nossa interpretação é de que as conjunções adversativas dão ao texto uma característica de texto argumentativo que tem a potencialidade de refletir mais fortemente ideologias e significados contrastantes, dado que o discurso pretende atingir um público bastante direcionado. No entanto, é preciso assinalar que, em alguns fragmentos a argumentação concebida de maneira frágil porque se referem a contraposições referentes a ideias internas ao texto, e não sobre opiniões distintas acerca do mesmo assunto e, ainda, aquelas que se caracterizam por concessão e não embate. A função desse operador argumentativo, na maioria dos casos, se aproxima muito mais de conector interfrástico que se presta a garantir a continuidade (conjunção argumentativa) do texto do que o tensionamento de posições contrastantes.

Passemos agora a análise das argumentações por conjunção no artigo 25.66 .2 e 26.67.4, sintetizados na Tabela 13 . 
Tabela 13:

Ocorrências de operadores argumentativos de conjunção por artigo

\begin{tabular}{lccccrr}
\hline \multirow{2}{*}{ Operador } & \multicolumn{2}{c}{ Artigo 25.66.2 } & \multicolumn{2}{c}{ Artigo 26.67.4 } & \multicolumn{2}{c}{ Total } \\
\cline { 2 - 6 } & Ocorrência & \% & Ocorrência & \% & Ocorrência & \% \\
\hline Ademais & 0 & 0,00 & 3 & 10,34 & 3 & 5,00 \\
Adicionalmente & 2 & 6,45 & 6 & 20,69 & 8 & 13,33 \\
Ainda & 1 & 3,23 & 1 & 3,45 & 2 & 3,33 \\
Além & 6 & 19,35 & 5 & 17,24 & 11 & 18,33 \\
Bem como & 10 & 32,26 & 6 & 20,69 & 16 & 26,67 \\
Com isso & 0 & 0,00 & 1 & 3,45 & 1 & 1,67 \\
Desse modo & 1 & 3,23 & 0 & 0,00 & 1 & 1,67 \\
E & 3 & 9,68 & 3 & 10,34 & 6 & 10,00 \\
Em seguida & 1 & 3,23 & 1 & 3,45 & 2 & 3,33 \\
Outrossim & 2 & 6,45 & 0 & 0,00 & 2 & 3,33 \\
Também & 3 & 9,68 & 3 & 10,34 & 6 & 10,00 \\
Tampouco & 2 & 6,45 & 0 & 0,00 & 2 & 3,33 \\
\hline Total & 31 & 100,00 & 29 & 100,00 & 60 & 100,00 \\
\hline
\end{tabular}

No artigo 25.66.2 identificamos a aplicação dos operadores argumentativos de conjunção: "bem como" (32,26\%); “além" (19,35\%); "e" e “também" (9,68\% cada); “adicionalmente", "tampouco" e "outrossim" (6,45\% cada); "desse modo", "em seguida" e "ainda" (3,23\%); cuja representatividade é de $21,53 \%$ do total dos operadores argumentativos empregados no artigo e que tomamos para análise. Já no artigo 26.67.4, temos: "adicionalmente" e "bem como" (20,69\% cada); "além" (17,24\%); "ademais", "e" e “também" (10,34\% cada); "ainda", “com isso" e "em seguida" (3,45\% cada). Tomando os operadores de conjunção/adição usados nos dois artigos, identificamos que o mais utilizado foi "bem como" que corresponde a $26,67 \%$ dos casos (16 operadores de conjunção, dentre as 60 ocorrências selecionadas).

Podemos afirmar que as argumentações de conjunção/adição realizadas a partir dos operadores "bem como", "e", "além" e "desse modo, adicionalmente" se constituem, dentro dos seus respectivos parágrafos, em atos de fala que agregados concorrem para consolidação de um pensamento que tem validade no mundo acadêmico e científico.

Estudos internacionais, sobretudo em países europeus, têm explorado essa temática e proporcionado avanços na compreensão dos efeitos da adoção dos IFRS sobre a informação contábil em si, bem como sobre os usuários dessa informação (Ashbaugh \& Pincus, 2001; Barth et al., 2008; Garanina \& Kormiltseva, 2014; Kargin, 2013; Jarva \& Lantto, 2012; Landsman, Maydew, \& Thornock, 2012; Soderstrom \& Sun, 2007). [grifo nosso]. (Tópico 1, § 2º , p. 229).

Algumas pesquisas, sob diversas perspectivas, foram desenvolvidas nesse sentido, porém os resultados obtidos ainda são divergentes (Costa, 2012; Lima, 2010; Macedo, Machado, Machado, \& Mendonça, 2013; Oliveira \& Lemes, 2011; Rodrigues, 2012; Santos, Lima, Freitas, \& Lima, 2011). E é nesse contexto que se insere o presente estudo, cujo objetivo é avaliar, no cenário brasileiro, o efeito da adoção dos IFRS sobre a relevância informacional do lucro líquido, visando, assim, contribuir com uma maior compreensão do tema. [grifo nosso] (Tópico $1, \S 3^{\underline{o}}$, p. 229).

A investigação aqui desenvolvida contemplou a capacidade associativa e a tempestividade 
informacional do lucro contábil. Entretanto, além desses dois aspectos, pesquisas têm sugerido que o conservadorismo; a existência de poucas oportunidades para o gerenciamento de resultados; e a persistência dos lucros, por exemplo, podem capturar importantes dimensões da qualidade da informação contábil de uma firma (Ball, 2006; Leuz \& Wysock, 2008). Portanto, é possível que tais fatores também contribuam com a relevância informacional, desse modo, adicionalmente, buscou-se também avaliar os efeitos da adoção dos IFRS sobre o nível de conservadorismo condicional presente no lucro contábil, por tratar-se de uma importante característica relacionada à tempestividade informacional. [grifo nosso] (Tópico $5^{\circ}, \S 3^{\circ}$, p. 229).

Significativamente usados no texto, os argumentos de conjunção foram identificados em geral após o emprego de operadores de conclusão, explicação e/ou comprovação (que trataremos a seguir), isoladamente agregando nova informação ao texto ou sendo interligando um ato de fala a um intertexto manifesto - citação/assertiva que possui autoridade científica. Para ilustrar esta última situação temos no Referencial Teórico as estruturas frásticas relativas à seção 2.1 e 2.2 do artigo 25.66.2, apresentadas na Tabela 11, as quais revelam que os conectores argumentativos de conjunção “e”, "“também”, "bem como", "por sua vez" e "além disso", que interligam ideias numa mesma oração e entre orações de um mesmo parágrafo, contêm aditivas que sustentam atos de fala dos autores do artigo por meio do ato de fala de outros autores em outros artigos - intertexto manifesto.Conforme podemos exemplo, a seguir:

Do mesmo modo, na Alemanha, Hung e Subramanyam (2007) constataram que os ativos totais e o patrimônio líquido, bem como as variações deste e do lucro líquido, são maiores sob os IFRS e que o patrimônio líquido, frente ao lucro líquido, exerce uma função mais importante na avaliação das firmas e possui maior associação com o preço das ações. A constatação principal desse estudo foi a alteração provocada pelos IFRS na dinâmica da informação contábil para uma parcela dos usuários.(Tópico 2.2, § $8^{\underline{o}}$, p. 230).

Inferimos que no artigo 25.66 .2 os autores manifestam por meio dos operadores argumentativos de conjunção com a preocupação de vincular parte significativa dos atos de fala a assertivas decorrentes de conclusões de pesquisadores que se dedicaram anteriormente ao tema, realizando estudos correlatos - atitude comum nos artigos científicos da área contábil. Vejamos os seguintes atos de fala:

Algumas pesquisas, sob diversas perspectivas, foram desenvolvidas nesse sentido, porém os resultados obtidos ainda são divergentes (Costa, 2012; Lima, 2010; Macedo, Machado, Machado, \& Mendonça, 2013; Oliveira \& Lemes, 2011; Rodrigues, 2012; Santos, Lima, Freitas, \& Lima, 2011). E é nesse contexto que se insere o presente estudo, cujo objetivo é avaliar, no cenário brasileiro, o efeito da adoção dos IFRS sobre a relevância informacional do lucro líquido, visando, assim, contribuir com uma maior compreensão do tema [grifo nosso]. (Tópico $1, \S 3^{\mathfrak{0}}$, p. 229).

Do mesmo modo, na Alemanha, Hung e Subramanyam (2007) constataram que os ativos totais e o patrimônio líquido, bem como as variações deste e do lucro líquido, são maiores sob os IFRS e que o patrimônio líquido, frente ao lucro líquido, exerce uma função mais importante na avaliação das firmas e possui maior associação com o preço das ações. [grifo nosso].(Tópico 1, § 8ํㅡ, p. 230).

Jarva e Lantto (2012), por sua vez, analisando os IFRS vis-à-vis as normas contábeis finlandesas, 
constataram que os lucros apurados de acordo com os IFRS são menos tempestivos, muito embora, marginalmente, forneçam maior capacidade preditiva de fluxos de caixa futuros. Além disso, verificaram que os ativos e passivos sob esses padrões apresentam menor associação com o preço das ações. Umas das razões apontadas para esses resultados seria o fato de que a Finlândia já dispunha de normas contábeis de alta qualidade. [grifo nosso]. (Tópico $2.2, \S 8^{\underline{0}}$, p. 231).

Podemos acrescentar que além de ser um recurso utilizado pelos autores para conferir autoridade ao discurso ao ligar um ato de fala dos autores do texto a atos de fala de outros autores em outros de outros textos (intertexto manifesto) a conjunção tem a potencialidade de transferir parte da responsabilidade ao autor do primeiro enunciado ou de reafirmar o ponto de vista a partir de dois atos de fala que coadunam entre si e fortalecem o estabelecimento de uma ideia. Conforme listado na Tabela 11, na Introdução, no Referencial Teórico e na Metodologia o uso da conjunção se dá individualmente ou associado a argumentos de contrajunção, exemplificação, conclusão, explicação ou comprovação. Já nos Resultados e Considerações Finais esses operadores ocorreram fundamentalmente atrelados aos operadores de contrajunção - estamos nos referindo a tais operadores como de contrajunção porque essa é a essência dos mesmos, mas sustentamos o nosso posicionamento sobre o emprego equivocado de parte significativa dos mesmos.

No artigo 26.67.4, os operadores de conjunção representam 28,71\% do total das relações argumentativas estabelecidas, logo a conjunção é o operador coesivo mais utilizado pelos autores para a articulação das ideias na construção do texto. Selecionamos alguns desses operadores para análise que são: "adicionalmente", "além" e "bem como". Vejamos alguns exemplos de aplicação no nesse artigo:

Adicionalmente, a Lei 11.638/07 introduziu a obrigatoriedade da divulgação da Demonstração do Valor Adicionado (DVA) para as companhias abertas, que até a aprovação da referida Lei ainda não era exigida no Brasil, apesar de algumas empresas a divulgarem de maneira voluntária. Destaca-se que esse demonstrativo não é contemplado nas normas internacionais de contabilidade, emitidas pelo International Accounting Standards Board (IASB). [grifo nosso]. (Tópico 1, § 6ํㅜ, p. 58).

Além desta, o presente artigo possui cinco partes. Na seguinte, apresenta-se o referencial teórico, onde será abordada a relevância da informação contábil e a Demonstração do Valor Adicionado. Na terceira parte, aborda-se a metodologia. Na quarta, os resultados da pesquisa. Na quinta, a conclusão. E, por fim, as referências. [grifo nosso]. (Tópico $1, \S 13^{\circ}$, p. 58).

De Luca (1998) considera que a DVA é a parte do balanço social destinada a apresentar informações de natureza econômica aos vários usuários, demonstrando o desempenho econômico da empresa e seu relacionamento com a sociedade. Para Santos (2007), a DVA é um componente do Balanço Social e "deve ser entendida como a forma mais competente criada pela Contabilidade para auxiliar na medição e demonstração da capacidade de geração, bem como de distribuição da riqueza de uma entidade" (Santos, 2007, p. 37). Destaca-se que tanto Santos (2007) quanto De Luca (1998), entendem que a DVA é parte integrante do balanço social. [grifo nosso]. (Tópico $3, \S 12^{\circ}$, p. 61 ).

Além das vantagens da DVA apresentadas por Riahi-Belkaoui (1992), especialmente no contexto 
brasileiro, a DVA pode ser utilizada como ferramenta para avaliar as contribuições das empresas, quando da concessão de benefícios fiscais, além de ser uma alternativa para o cálculo do PIB, como acrescenta Santos (2007, p. 38): “[...] parece que é inquestionável seu auxílio no cálculo do PIB e de indicadores sociais extremamente importantes. As decisões de investimentos por áreas, regiões, Estados etc. terão nessa demonstração excelente instrumental para a solução de conflitos." [grifo nosso]. (Tópico $3, \S 15^{\circ}$, p. 61).

Em todos os fragmentos anteriormente apresentados temos a conjunção argumentativa de conjunção revelando uma forte característica do texto científico: a utilização de falas de outros autores que possuem autoridade científica e a dão respaldo ou dividem com os autores do texto a responsabilidade por uma assertiva - geralmente por meio de intertextualidade manifesta. De fato, este é um aspecto mais comum ao Referencial Teórico e à Metodologia que a Introdução, Análise de Dados e a Conclusão.

O termo "adicionalmente" (Tópico $1, \S 6^{\underline{0}}$, p. 58), citado anteriormente, é empregado como operador no início do parágrafo com a função de trazer informações normativas ao texto - o termo que liga um discurso legal. No segundo fragmento iniciado pelo operador "além" os autores empregam um argumento coesivo de conjunção para dar fluência/continuidade ao texto, também interligando ideias entre parágrafos representando a fala dos autores. Já no Tópico $3\left(\S 12^{\circ}\right.$, p. 61 e $\S 15^{\circ}$, p. 61) temos a aditiva interligando atos de fala de outros autores que comungam da mesma ideia sobre a temática.

Passemos agora aos conectivos argumentativos de conclusão representam 12,50\% dos operadores argumentativos utilizados no artigo 25.66 .2 e $23,76 \%$ daqueles empregados no artigo 26.67.4 segundo operador mais utilizado neste artigo. Vejamos a Tabela 14:

Tabela 14:

Ocorrências de operadores argumentativos de conclusão por artigo

\begin{tabular}{lcccccr}
\hline & Operador & \multicolumn{2}{c}{ Artigo 25.66.2 } & \multicolumn{2}{c}{ Artigo 26.67.4 } & \multicolumn{2}{c}{ Total } \\
\cline { 2 - 7 } & Ocorrência & \multicolumn{1}{c}{$\%$} & Ocorrência & \% & Ocorrência & \% \\
\hline Assim & 12 & 66,67 & 11 & 45,83 & 23 & 54,76 \\
Dessa forma & 1 & 5,56 & 1 & 4,17 & 2 & 4,76 \\
Logo & 0 & 0,00 & 2 & 8,33 & 2 & 4,76 \\
Por fim & 4 & 22,22 & 5 & 20,83 & 9 & 21,43 \\
Portanto & 1 & 5,56 & 5 & 20,83 & 6 & 14,29 \\
\hline Total & 18 & 100,00 & 24 & 100,00 & 42 & 100,00 \\
\hline
\end{tabular}

Em relação ao artigo 25.66.2 temos que o operador argumentativo conclusivo mais utilizado foi "assim" que equivale a $66,67 \%$ das ocorrências que exploradas no artigo, seguido dos operadores "por fim" $(22,22 \%)$ e "portanto" e "dessa forma" (5,56\% cada). No artigo 26.67.4 temos "assim" como 45,83\% das ocorrências, "por fim" e "portanto" (20,83\% cada), "logo" $(8,33 \%)$ e dessa forma com $(5,56 \%)$ das ocorrências. Desta forma, podemos perceber 
que o operador "assim" foi o mais utilizado nos textos com 54,76\% das ocorrências (23 dos 42 operadores de argumentação conclusivos).

Dentre as aplicações evidenciadas no texto, chamou-nos à atenção o uso do operador "assim" nos fragmentos destacados. Tal fato se deve a compreensão de que o argumento de conclusão empregado se respalda, estrategicamente, em estudos anteriores para conferir autoridade às argumentações. Observemos:

\footnotetext{
Uma das mais importantes motivações para adoção dos International Financial Reporting Standards IFRS é a comparabilidade da informação contábil entre os países. Assim, busca-se estabelecer uma linguagem única para os mercados e um ambiente favorável a uma maior fluidez do fluxo de capitais (Ball, 2006; Lima, 2010; Niyama, 2007). [grifo nosso]. (Tópico 1, § 1ํㅜ, p. 229).

\begin{abstract}
Assume-se, assim, que os conceitos e os critérios de reconhecimento, mensuração e divulgação estabelecidos pelos IFRS oferecem uma qualidade informacional superior que implica na utilidade da informação contábil que é produzida (Barth, Landsman, \& Lang, 2008; Leuz \& Wysock, 2008). Estudos internacionais, sobretudo em países europeus, têm explorado essa temática e proporcionado avanços na compreensão dos efeitos da adoção dos IFRS sobre a informação contábil em si, bem como sobre os usuários dessa informação [grifo nosso]. (Ashbaugh \& Pincus, 2001; Barth et al., 2008; Garanina \& Kormiltseva, 2014; Kargin, 2013; Jarva \& Lantto, 2012; Landsman, Maydew, \& Thornock, 2012; Soderstrom \& Sun, 2007). [grifo nosso]. (Tópico 1, § 2º , p. 229).
\end{abstract}

Enquanto no primeiro parágrafo, os autores fazem uma afirmação e empregam o operador argumentativo para conectar uma citação indireta como fechamento, conferindo autoridade científica ao ato de fala, no segundo parágrafo identificamos uma citação apresentada como ideia conclusiva na abertura do parágrafo. A nossa interpretação é de que, neste último caso, essa conclusão fornece suporte a um ato de fala do parágrafo anterior ao se fundamentar em uma autoridade científica. Interpretamos, ainda, que há certa insegurança dos autores ao estabelecerem a conclusão, pois além de fazer uso de um intertexto manifesto para o fechamento (fala que não pertence aos mesmos) essa conclusão é seguida de outro intertexto manifesto que se fundamenta em vários estudiosos do tema. Em geral, as conclusões são fechamentos de ideias dos autores do texto e representam uma oportunidade de expressão de um ponto de vista. Quando se faz a conclusão por meio de citação indireta o autor da voz a outros autores, calando-se diante do fato.

Nota-se que essa conclusão expressa o discurso de outrem, ou seja, os autores se utilizam textualmente da fala de outros pesquisadores para construir a sua própria conclusão. A nosso ver, os operadores argumentativos são usados novamente para validar e persuadir o consumidor do texto a partir de atos de fala que possuem autoridade científica. Apesar de sabermos que as citações representam a aderência as ideias nela contidas, temos em mente que o seu uso sequenciado pode silenciar opiniões peculiares/características do discurso original dos autores que delas se apropriam, o texto acaba por carecer de aspectos críticos e 
reflexivos.

Além de empregadas isoladamente como, por exemplo, no Tópico $1, \S 1^{\underline{0}}$, p. 229;

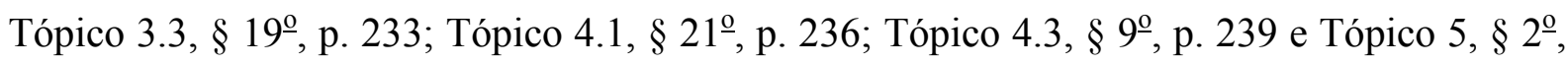
p. 240 temos conclusivas: após operadores de contrajunção e conjunção (Tópico $1, \S 3^{\underline{o}}$, p. 229), apenas com contrajunção (Tópico 4.3, § 4º̣, p. 238), após operadores de contrajunção, conjunção e especificação/exemplificação (Tópico $1, \S 5^{\circ}$, p. 229), após e antes operadores de

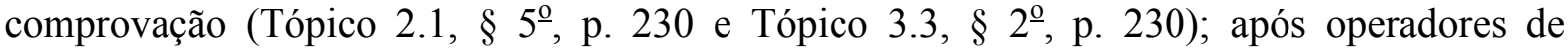
explicação/justificativa (Tópico 2.1, § $7^{7}$, p. 230), antes e após uma comparação (Tópico 4.1, $\S 19^{\circ}$, p. 236), antes e após uma generalização (Tópico 4.1, $\S 23^{\circ}$, p. 236), após operador de contraste e explicação (Tópico $5, \S 6^{0}$, p. 240) e após conjunção, contraste, comparação e explicação/justificativa (Tópico $5, \S 7^{\circ}$, p. 240).

Podemos inferir que seja de maneira isolada ou em frases encadeadas por outros operadores argumentativos, a conclusão no texto argumentativo caracteriza-se fundamentalmente como fechamento de ideias de um discurso intencional, cujo objetivo maior é persuadir o leitor conduzindo-o a um raciocínio que vai sendo construído paulatinamente a cada uma dessas argumentações conclusivas. $O$ discurso vai se manifestando como materialização ideológica que favorece a criação de identidades, ou seja, "a forma por meio da qual, as pessoas podem agir sobre o mundo e especialmente sobre os outros, como também um modo de representação" (Fairclough, 2008, p. 91).

No artigo 26.67.4, o operador de argumentação conclusivo possui elevada representatividade dentre aqueles utilizados pelos autores, segundo operador mais utilizado. Vejamos a sua aplicação nos parágrafos a seguir:

Esses estudos, ressaltam Brown, Lo, e Lys (1999), são normalmente conduzidos pela aplicação de análises de regressão, tendo como variável dependente uma proxy relacionada ao preço das ações e como variáveis independentes as informações contábeis, sendo mais comum o uso de proxies relacionadas ao lucro e ao patrimônio líquido. Assim, complementam Barth et al. (2001), os testes conduzidos têm foco nos coeficientes das informações contábeis na equação de regressão.[grifo nosso]. (Tópico $3, \S 10^{\circ}$, p. 58).

Pesquisas empíricas sobre a DVA, em nível internacional, são escassas, possivelmente pelo fato dos padrões internacionais de contabilidade não contemplarem a DVA como parte do conjunto de demonstrações financeiras a ser apresentada no relatório anual, sendo, portanto, uma divulgação voluntária (Van Staden, 2000). Dentre os estudos encontrados sobre DVA, destacam-se pesquisas que buscaram averiguar a utilização da DVA (Van Staden, 1998; Stainbank, 2009) e pesquisas que tiveram foco na magnitude de seu conteúdo informacional (Riahi-Belkaoui \& Fekrat, 1994; Riahi-Belka-oui \& Picur, 1994; Riahi-Belkaoui \& Picur, 1999). [Grifo nosso]. (Tópico 3, § 15, p. 61).

No estudo de Crippa e Coelho (2012), observa-se a mesma linha de pesquisa, porém utilizando uma amostra de empresas de capital aberto no período de 2007 a 2010, já incluindo um período de publicação obrigatória da DVA. Os autores encontraram evidências de que existe relação positiva significativa entre a riqueza gerada pelas empresas da amostra com o retorno das ações, concluindo, 


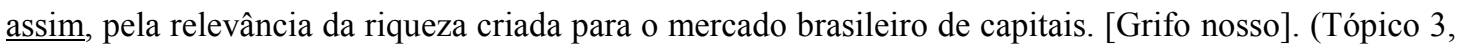
$\S 20^{\circ}$, p. 62).

Ao examinarmos o emprego do operador argumentativo "assim", destacado anteriormente (Tópico $1, \S 3^{\circ}$, p. 58), identificamos uma condição um tanto incomum em relação a argumentação conclusiva. Consideramos incomum porque, na maioria dos casos em que é empregado, o operador conclusivo exprime um raciocínio do autor como culminância de uma ideia anteriormente expressa. Em outros casos, usa-se o operador de conclusão para expressão do pensamento dos autores sobre o discurso de outrem. Porém, no caso específico desse fragmento os autores apresentam um ato de fala de outros autores e, em seguida, complementa com a conclusão de outros autores sobre este ato de fala - em nenhum momento os autores do artigo 26.67.4 se posicionam no parágrafo.

No Tópico 3 ( $§ 15^{\circ}$, p. 61) temos o uso do "portanto" que introduz uma citação indireta com o objetivo de validar um ato de fala anterior. A nosso ver, esta conclusiva manifesta um excesso de zelo ou insegurança argumentativa, logo desnecessária ao ato de fala. Pensamos que as conclusões devem ser exploradas em artigos científicos para oportunizar a compreensão sobre a concepção dos autores, e não, necessariamente, tornar-se uma estratégia para conferir autoridade científica por meio de uma fala comprobatória. Já no Tópico 3 ( $§ 20^{\circ}$, p. 62) do artigo 26.67 .4 os autores fazem uso da conclusiva para fechamento de um ato de fala que reflete os resultados de pesquisas de outros autores, isentando-se de uma opinião sobre o assunto abordado.

Examinando os fragmentos a seguir podemos estabelecer uma análise:

Obteve-se um coeficiente de determinação de 0,713 evidenciando que $71,3 \%$ da variação no preço das ações é explicada pela variação do LLPA e do PLPA. Quanto à significância, o painel A, da Tabela 2, por meio da estatística $t$, indica que tanto a variável LLPA, quanto a PLPA, mostraram-se significativas estatisticamente ao nível de $1 \%$, bem como apresentaram o sinal previsto. Assim sendo, tem-se a confirmação da relevância das informações de lucro e patrimônio líquido para o mercado brasileiro de capitais. [grifo nosso]. (Tópico $5, \S 5^{\circ}$, p. 64).

$\underline{\text { Assim, }}$ procura-se analisar o impacto da obrigatoriedade de divulgação da DVA, por meio do estudo de value relevance das informações sobre a riqueza criada. Diante do exposto, questiona-se a existência de conteúdo informacional relevante da DVA para o mercado de capitais brasileiro. [grifo nosso]. (Tópico $1, \S 10^{\circ}$, p. 58).

Justifica-se a realização da presente pesquisa o fato de serem escassos os estudos sobre o assunto, possivelmente por ser a DVA uma demonstração não obrigatória, em nível internacional, e, no Brasil, ser obrigatória apenas a partir de 2007 para as companhias abertas. Adicionalmente, sabe-se que a inclusão de um novo demonstrativo obrigatório acarreta em aumento de trabalho e, consequentemente, custos decorrentes de sua elaboração, auditoria e publicação, justificando estudos que investiguem se a sua apresentação proporciona aos usuários benefícios, que podem ser induzidos pelo value relevance. Por fim, estudos anteriores já foram realizados, mas os resultados das referidas pesquisas ainda não são suficientes para afirmar sobre a existência de conteúdo informacional da DVA, especialmente em 
decorrência do pequeno período analisado nos estudos anteriores. [grifo nosso]. (Tópico $1, \S 12^{\underline{0}}$, p. 59).

Os parágrafos destacados refletem a situação distinta daquela evidenciada na análise anterior, os autores empregam o conectivo "assim" construir uma conclusão sobre os achados da pesquisa, a qual se fundamenta nos dados estatisticamente obtidos. No segundo caso o emprego do "assim" também representa reflexão dos autores acerca de ideias expostas anteriormente, as quais culminam no objetivo da pesquisa que realizaram. No último parágrafo temos o uso do "por fim" para o fechamento do parágrafo que exprime a justificativa dos autores para a realização da pesquisa.

Em se tratando dos operadores de explicação ou justificativa, evidenciados na Tabela 15, identificamos que estes representam 9,03\% dos operadores empregados no artigo 25.66.2. Os operadores mais usados foram, especificamente, "uma vez que" $(53,85 \%)$, "haja vista" $(15,38 \%)$ e "em outras palavras", "mesmo que", "pois" e "por oportuno" (7,69\% cada). No artigo 26.67.4 observamos os operadores "por sua vez" (37,50\%); “em outras palavras", "para tanto", "pois", e "visto que" (12,50\% cada); "por tais" e "uma vez que" (6,25\%). Notamos que o operador "uma vez que" é o mais empregado nos dois artigos representando $27,59 \%$ (8 operadores dentre os 29 selecionados para análise), conforme a Tabela 15:

Tabela 15:

Ocorrências de operadores argumentativos de explicação/justificativa por artigo

\begin{tabular}{lcrrrrr}
\hline \multicolumn{1}{c}{ Operador } & \multicolumn{2}{c}{ Artigo 25.66.2 } & \multicolumn{2}{c}{ Artigo 26.67.4 } & \multicolumn{2}{c}{ Total } \\
\cline { 2 - 7 } & Ocorrência & $\mathbf{\%}$ & Ocorrência & \% & Ocorrência & \% \\
\hline Em outras palavras & 1 & 7,69 & 2 & 12,50 & 3 & 10,34 \\
Haja vista & 2 & 15,38 & 0 & 0,00 & 2 & 6,90 \\
Mesmo que & 1 & 7,69 & 0 & 0,00 & 1 & 3,45 \\
Ou seja & 0 & 0,00 & 6 & 37,50 & 6 & 20,69 \\
Para tanto & 0 & 0,00 & 2 & 12,50 & 2 & 6,90 \\
Pois & 1 & 7,69 & 2 & 12,50 & 3 & 10,34 \\
Por oportuno & 1 & 7,69 & 0 & 0,00 & 1 & 3,45 \\
Por tais & 0 & 0,00 & 1 & 6,25 & 1 & 3,45 \\
Uma vez que & 7 & 53,85 & 1 & 6,25 & 8 & 27,59 \\
Visto que & 0 & 0,00 & 2 & 12,50 & 2 & 6,90 \\
\hline Total & 13 & 100,00 & 16 & 100,00 & 29 & 100,00 \\
\hline
\end{tabular}

Não identificamos qualquer equívoco no emprego dos operadores de explicação nos artigos 25.66.2 e 26.67.4 e, assim, podemos afirmar que esse operador argumentativo foi utilizado com fidelidade de sentido, comunicando sem provocar ruídos, vejamos:

É importante frisar que o enfrentamento dessa questão não incorpora a avaliação acerca da qualidade da informação produzida sob os IFRS, tampouco se tais padrões são superiores aos padrões domésticos, uma vez que não traça qualquer comparação entre os critérios prescritos por esses conjuntos normativos, bem como não discute aspectos acerca de como essa informação deveria ser, mas sim, busca avaliar o quão útil ela é (ou aparenta ser) sob a perspectiva dos participantes do mercado acionário brasileiro.[Grifo nosso]. (Artigo 25.66.2, Tópico 1, § 8oㅜ p. 229). 
A representatividade dos períodos para os quais se observam retornos negativos pode sinalizar a ocorrência de eventos não associados às variações negativas dos preços que não se relacionam com o lucro contábil na proporção dessas variações. Interessante notar que, conforme os resultados, esses eventos não estariam vinculados à adoção dos IFRS, uma vez que as variáveis representativas das interações entre $\mathrm{DR}_{\mathrm{it}}, \mathrm{R}_{\text {it }}$ e as dummies indicativas desse período não se mostraram significantes. [Grifo nosso]. (Artigo 25.66.2, Tópico 1, § 8º , p. 239).

No que diz respeito ao preço das ações, considerou-se o preço da ação de maior liquidez da empresa na data de 30 de abril do ano subsequente ao da publicação das demonstrações contábeis. Os dados referentes à riqueza criada foram obtidos junto à base de dados da FIPECAFI. Já as informações sobre preço, número de ações, Lucro Líquido e Patrimônio Líquido foram extraídas do banco de dados da Economática. Uma vez que os dados referentes à riqueza criada foram fornecidos em dólares americanos, as informações sobre preço, Lucro Líquido e Patrimônio Líquido também foram coletadas nessa mesma moeda. (Artigo 26.67.4, Tópico 5, § 19ํㅜㄹ. p3).

Com isso, percebe-se que os resultados obtidos até aqui mostram que a riqueza criada, informação advinda da DVA, não só possui relevância para o mercado brasileiro de capitais, como adiciona conteúdo informacional às informações de lucro e patrimônio líquido. Ou seja, percebe-se que existe conteúdo informacional marginal na DVA para os investidores. Esse é um achado que as pesquisas anteriores ainda não tinham observado. (Artigo 26.67.4, Tópico 5, § 9º, p. 66).

Os fragmentos que destacamos evidenciam o emprego do argumento de explicação ou justificativa "uma vez que" e "ou seja". Podemos perceber por meio dos três parágrafos que operador argumentativo de justificativa ou explicação introduz, em geral, um esclarecimento que decorre da maneira que os autores percebem o fato, logo é um argumento que aproxima o consumidor do texto das vozes desses autores.

A exemplo do que ocorreu com o operador de explicação ou justificativa apresentado anteriormente, não notamos nos artigos em 25.66.2 e 26.67.4 qualquer inadequação no uso dos operadores argumentativos de especificação ou exemplificação que equivalem a 7,64\% e $5,94 \%$ destes artigos, respectivamente. Observemos na Tabela 16 a seguir o uso desses operadores nos artigos.

Tabela 16:

Ocorrências de operadores argumentativos de especificaçãolexemplificação por artigo

\begin{tabular}{lcccccr}
\hline \multicolumn{1}{c}{ Operador } & \multicolumn{2}{c}{ Artigo 25.66.2 } & \multicolumn{2}{c}{ Artigo 26.67.4 } & \multicolumn{2}{c}{ Total } \\
\cline { 2 - 7 } & Ocorrência & \% & Ocorrência & \% & Ocorrência & \% \\
\hline A exemplo & 1 & 9,09 & 0 & 0,00 & 1 & 5,88 \\
Em especial & 1 & 9,09 & 0 & 0,00 & 1 & 5,88 \\
Por exemplo & 3 & 27,27 & 2 & 33,33 & 5 & 29,41 \\
Sobretudo & 3 & 27,27 & 0 & 0,00 & 3 & 17,65 \\
Tais como & 3 & 27,27 & 4 & 66,67 & 7 & 41,18 \\
\hline Total & 11 & 100,00 & 6 & 100,00 & 17 & 100,00 \\
\hline
\end{tabular}

Os conectivos de especificação ou exemplificação mais empregados no texto foram "por exemplo", "tais como" e "sobretudo" (27,27\% cada) e "a exemplo" e "em especial" (9,09\% cada) no artigo 25.66.2, Já no artigo 26.67.4 temos "tais como" empregado 66,67\% 
das vezes, seguido de "por exemplo" (33,33\%). O operador mais utilizado, considerando o total selecionado nos dois artigos foi "tais como" $41,18 \%$ ( 7 dos 17 operadores argumentativos selecionados). Identificamos que tais conectivos, geralmente, aparecem em meio a orações que possuem argumento de comprovação, contrajunção, generalização e comparação. Conforme a seguir:

O processo de convergência às normas internacionais de contabilidade no Brasil teve como marco principal a promulgação da Lei n. 11.638/2007, que promoveu alterações nas leis n. 6.404/1976 (Lei das S.A.) e n. 6.385/1976, com a finalidade de efetivar, no sistema jurídico nacional, essa convergência normativa. Processo este que, conforme destacam Dantas, Rodrigues, Niyama, e Mendes. (2010), desenvolvia-se desde a década de 1990, como, por exemplo, os esforços institucionais da CVM no sentido de aprimorar as normas contábeis brasileiras com a incorporação de preceitos do padrão do IASB. [grifo nosso]. (Artigo 25.66.2, Tópico 2.1, § 6º, p. 230).

Por outro lado, frise-se que parte desses resultados contraria aqueles obtidos por uma série de estudos realizados no Brasil, a exemplo de Costa, Costa e Lopes (2006), Coelho e Lima (2007), Santos e Costa (2008) e Almeida, Scalzer, e Costa (2008). No entanto, as divergências metodológicas existentes, tais como técnicas estatísticas empregadas, tamanho da amostra, período etc., são aspectos que devem ser considerados. [Grifo nosso]. (Artigo 25.66.2, Tópico 1, § 8ํㅡ, p. 239).

A utilidade das demonstrações financeiras depende, fundamentalmente, da relevância das informações que são divulgadas aos usuários. De maneira geral, a informação contábil pode ser dita relevante quando possui algumas características, tais como: (i) contribui para a redução da assimetria informacional existente entre os usuários internos (gestores, executivos etc.) e os usuários externos da empresa (acionistas, credores, governo etc.); (ii) auxilia o usuário na avaliação dos efeitos potenciais de transações passadas, presentes e futuras nos fluxos de caixa futuros (valor preditivo) e/ou confirmando ou corrigindo suas avaliações anteriores (valor confirmatório); (iii) faz com que a decisão do usuário seja alterada pela sua utilização, ou seja, o usuário toma uma decisão diferente da que teria tomado, caso não tivesse determinada informação. [Grifo nosso]. (Artigo 26.67.4, Tópico 1, § 1ํㅜ p. 58).

Outros estudos também podem ser destacados, tais como: Foster (1977); Board e Walker (1990); Strong e Walker (1993); Harris, Lang, e Moller (1994); Collins, Pincus, e Xie (1999); Francis e Schipper (1999); Dhaliwal, Subramanyam, e Trezevant (1999); Sarlo Neto (2004); Costa e Lopes (2007); Lopes, Sant'Anna, e Costa (2007); Galdi e Lopes (2008); Bastos, Nakamura, David, e Rotta (2009); Malacrida (2009) e Zanini, Cañibano, e Zani (2010). [Grifo nosso]. (Artigo 26.67.4, Tópico 2, § 6⿳⺈,p p. 59).

Pode-se dizer que a DRE utiliza o critério da natureza, enquanto a DVA utiliza o critério do benefício. Por exemplo, na DRE, os salários de empregados envolvidos no processo produtivo serão considerados como custos e os salários da administração como despesas. Já na DVA, independentemente da natureza, custo ou despesa, salários pagos correspondem ao valor adicionado destinado aos empregados, ou seja, é utilizado o critério de benefício da renda (Iudícibus, Martins, Gelbcke, \& Santos, 2010). [grifo nosso]. (Artigo 26.67.4, Tópico 3, § 5ํㅜ , p. 60).

Percebemos que, no artigo 25.66.2, o termo "por exemplo" aparece após o operador argumentativo "conforme" que exprime comprovação e "tais como" após a introdução do operador adversativo "no entanto" para apontar as divergências metodológicas dos resultados de pesquisa. No artigo 26.67 .4 "tais como" no Tópico 1 ( $§ 1^{\underline{o}}$, p. 58) o autor inicia o argumento como uma declaração de generalização ou extensão que é esclarecida por meio da 
especificação, já no Tópico 2 (§ $6^{\circ}$, p. 59) de "tais como" introduz exemplos de estudos que se dedicam a avaliação da relevância da informação contábil. Em "por exemplo" Tópico 3 ( $5^{\text {oo }}$, p. 60), do mesmo artigo, percebemos que há um argumento de argumentação comparativo iniciando o ato de fala do parágrafo que é seguido de uma exemplificação.

Desta maneira, pela própria função desse operador argumentativo, temos que na maioria dos casos ele é acessório a uma argumentação principal, o que não significa considerá-lo como menos significativo para tornar o texto mais compreensível ao seu consumidor. Em outras palavras, podemos afirmar que as exemplificações funcionam como prerrogativa que traz mais um elemento de segurança a oração no discurso dos autores, ou por eles apresentados de maneira impessoal no texto. Essas exemplificações tanto aclaram as ideias como são bem-vindas ao texto científico, porém é preciso que tenhamos o cuidado acerca do seu uso excessivo porque, em vez de funcionar como elemento de coesão e tradução de conhecimento aprofundado, pode tornar o texto cansativo, exprimir excessiva vaidade (erudição desnecessária) ou passar ideia de insegurança/imaturidade em matéria de discurso científico. Como dissemos, não podemos esquecer que a exemplificação não é argumento central do discurso científico, todavia, se trata de mais uma maneira de garantir a sua sustentação e/ou comprovar a conformidade e coerência dos atos de fala - a exemplificação é um dos tipos de argumentos mais primários que existem no nível retórico.

Passemos agora aos operadores argumentativos de comparação, que representa 9,03\% dos operadores usados no artigo 25.66 .2 e 1,98\% no artigo 26.67.4, bem como os de comprovação que representa 8,33\% em 25.66 .2 e 7,92\% em 26.67.4. Tais operadores podem ser evidenciados na Tabela 17 e 18:

Tabela 17:

Ocorrências de operadores argumentativos de comparação por artigo

\begin{tabular}{lcccccr}
\hline \multirow{2}{*}{ Operador } & \multicolumn{2}{c}{ Artigo 25.66.2 } & \multicolumn{2}{c}{ Artigo 26.67.4 } & \multicolumn{2}{c}{ Total } \\
\cline { 2 - 7 } & Ocorrência & \% & Ocorrência & \% & Ocorrência & \% \\
\hline Do mesmo modo & 2 & 15,38 & 0 & 0,00 & 2 & 13,33 \\
Tal qual & 5 & 38,46 & 0 & 0,00 & 5 & 33,33 \\
Tanto ... quanto & 6 & 46,15 & 1 & 50,00 & 7 & 46,67 \\
Tanto ... como & 0 & 0,00 & 1 & 50,00 & 1 & 6,67 \\
\hline Total & 13 & 100,00 & 2 & 100,00 & 15 & 100,00 \\
\hline
\end{tabular}

De acordo com os dados da Tabela 17 temos que "tanto ... quanto" foi o operador mais utilizado equivalendo a 46,67\% das ocorrências dos artigos 25.66 .2 e 26.67 .4 tomados em conjunto. No artigo 25.66.2 temos o uso de "tanto ... quanto" em 46,15\% das argumentações, "tal qual" em 38,46\% e "do mesmo modo" em 15,38\%. No artigo 26.67 .4 temos "tanto ... quanto" e "tanto ... como" que de acordo com a nossa seleção aparecem uma única 
argumentação nos seguintes atos de fala: “destaca-se que tanto Santos (2007) quanto De Luca (1998), entendem que a DVA é parte integrante do balanço social” (Tópico 3, § 12º , p. 61) e em "entende-se que, em virtude de sua relevância, a DVA pode ser tratada tanto como a vertente econômica do balanço social, como a vertente social das demonstrações contábeis". [Grifo nosso]. (Tópico 3, § 13ํㅜ p. 61).

No artigo 25.66.2 temos, por exemplo, o operador comparativo "tanto . . quanto" utilizado para estabelecer comparações inerentes a variáveis intrínsecas ao estudo realizado, enquanto que o operador "tal qual" foi utilizado tanto para estabelecer um paralelo entre os resultados de outras pesquisas realizadas por outros autores e em comparações entre as variáveis tomadas para a análise na própria pesquisa. Vale ressaltar, que não identificamos qualquer equívoco que provocasse interpretação indevida ou por parte dos autores, tanto no que se refere ao operador argumentativo de comprovação quanto no operador de comparação.

A Tabela 18, a seguir, apresenta os operadores de comprovação encontrados nos artigos. Entendemos que o argumento de comprovação é uma maneira de conferir autoridade aos textos científicos e aqui o entendemos como sinônimo de conformidade.

Tabela 18:

Ocorrências de operadores argumentativos de comprovação por artigo

\begin{tabular}{lcccccc}
\hline & Operador & \multicolumn{2}{c}{ Artigo 25.66.2 } & \multicolumn{2}{c}{ Artigo 26.67.4 } & \multicolumn{2}{c}{ Total } \\
\cline { 2 - 7 } & Ocorrência & $\mathbf{\%}$ & Ocorrência & \% & Ocorrência & \% \\
\hline Conforme & 7 & 58,33 & 1 & 12,50 & 8 & 40,00 \\
De acordo & 5 & 41,67 & 5 & 62,50 & 10 & 50,00 \\
Segundo & 0 & 0,00 & 2 & 25,00 & 2 & 10,00 \\
\hline Total & 12 & 100,00 & 8 & 100,00 & 20 & 100,00 \\
\hline
\end{tabular}

Os operadores de comprovação, aqui considerados como sinônimo de conformidade, selecionados para análise no texto do artigo 25.66 .2 representam 8,33\% dos argumentos utilizados, são eles: “conforme" (58,33\%) e "de acordo com” (41,67\%). Já no artigo 26.67.4 temos que os operadores de comprovação representam 7,92\% do total empregado neste artigo, sendo "de acordo" empregado em 50\% dos casos, "conforme" em 40\% e "segundo" em 10\%.

Os operadores de comprovação foram fundamentadamente utilizados para evidenciar conformidade em relação a resultados de pesquisas científicas correlatas, bem como, sobre a análise emitida pelos próprios autores em relação às informações obtidas na própria pesquisa.

A Tabela 19 apresenta os operadores de contraste, salientamos que não houve ocorrência do argumento de contraste no artigo 26.67.4. No artigo 25.66 .2 tal argumento representa $4,86 \%$ dos operadores empregados, logo de baixa incidência no texto. "Por outro lado" é o operador argumentativo mais utilizado no artigo e aparece em 71,43\% (5 dos 7 
selecionados no texto).

Tabela 19:

Ocorrências de operadores argumentativos de contraste por artigo

\begin{tabular}{lcccccr}
\hline \multirow{2}{*}{ Operador } & \multicolumn{2}{c}{ Artigo 25.66.2 } & \multicolumn{2}{c}{ Artigo 26.67.4 } & \multicolumn{2}{c}{ Total } \\
\cline { 2 - 7 } & Ocorrência & \% & Ocorrência & \% & Ocorrência & \% \\
\hline Ao invés & 1 & 14,29 & 0 & 0,00 & 1 & 14,29 \\
Pelo contrário & 1 & 14,29 & 0 & 0,00 & 1 & 14,29 \\
Por outro lado & 5 & 71,43 & 0 & 0,00 & 5 & 71,43 \\
\hline Total & 7 & 100,00 & 0 & 0,00 & 7 & 100,00 \\
\hline
\end{tabular}

Vejamos alguns exemplos em que o mesmo foi empregado no texto do artigo 25.66.2, já que no artigo 26.67 .4 não há qualquer ocorrência:

Por outro lado, resultados divergentes são apontados por Callao, Jarne, e Laínez (2007), cujas evidências indicam que a adoção dos IFRS na Espanha não aprimorou a relevância dos relatórios financeiros para os participantes do mercado acionário local. Nesse estudo, constatou-se que a diferença entre o valor contábil e o valor de mercado das firmas espanholas se tornou maior com a adoção dos IFRS. [grifo nosso]. (Artigo 25.66.2, Tópico 2.2, § $7^{\circ}$, p. 230).

Já Kargin (2013), analisando os efeitos da adoção dos IFRS na Turquia, encontrou evidências que indicam que a adoção desses padrões não aprimorou o nível de associação entre o lucro contábil e o preço das ações, por outro lado, os resultados mostraram que o patrimônio líquido apresentou maior relevância no período pós-IFRS. [grifo nosso]. (Artigo 25.66.2, Tópico 2.2, § 12ำ p.231).

Por outro lado, frise-se que parte desses resultados contraria aqueles obtidos por uma série de estudos realizados no Brasil, a exemplo de Costa, Costa e Lopes (2006), Coelho e Lima (2007), Santos e Costa (2008) e Almeida, Scalzer, e Costa (2008). No entanto, as divergências metodológicas existentes, tais como técnicas estatísticas empregadas, tamanho da amostra, período etc., são aspectos que devem ser considerados. [grifo nosso]. (Artigo 25.66.2, Tópico 4.3, § 8º, p. 239).

Nestes parágrafos, os autores do artigo 22.65.2 utilizam operadores de contraste para fazer referência a resultados de pesquisas divergentes ou, ainda, uma situação de contraste dentro do próprio resultado de pesquisa. Apesar de não serem tão significativos em termos aplicação no texto, estes operadores são relevantes para evidenciar visões contrastantes acerca do assunto ou aspecto abordado, incluso aqueles intrínsecos à própria investigação. Julgamos como relevantes porque tais argumentos podem provocar os incômodos intelectuais e questionamentos com potencialidade de fomentar novos questionamentos e, quiçá, outras investigações.

Passemos a tratar dos os operadores de generalização, tais como: “de forma geral", "de maneira geral", "de uma maneira generalizada" e "de uma maneira geral". Estes foram os operadores de generalização que selecionamos nos textos dos artigos, sendo que nenhum deles é comum aos textos. Os operadores "de uma maneira generalizada" e "de uma maneira geral" aparecem no artigo 25.66.2, enquanto os operadores "de forma geral" e "de maneira 
geral” aparecem no artigo 26.67.4. Observemos a Tabela 20:

Tabela 20:

Ocorrências de operadores argumentativos de generalização por artigo

\begin{tabular}{lcccccr}
\hline \multicolumn{1}{c}{ Operador } & \multicolumn{2}{c}{ Artigo 25.66.2 } & \multicolumn{2}{c}{ Artigo 26.67.4 } & \multicolumn{2}{c}{ Total } \\
\cline { 2 - 7 } & Ocorrência & \multicolumn{1}{c}{$\%$} & Ocorrência & \multicolumn{1}{c}{$\%$} & Ocorrência & \% \\
\hline De forma geral & 0 & 0,00 & 1 & 50,00 & 1 & 20,00 \\
De maneira geral & 0 & 0,00 & 1 & 50,00 & 1 & 20,00 \\
De uma maneira generalizada & 1 & 33,33 & 0 & 0,00 & 1 & 20,00 \\
\hline De uma maneira geral & 2 & 66,66 & 0 & 0,00 & 2 & 40,00 \\
\hline Total & 3 & 100,00 & 2 & 100,00 & 5 & 100,00 \\
\hline
\end{tabular}

"De forma geral" e "de maneira geral" aparecem na mesma proporção no artigo 26.67.4, já no artigo 25.66.2 "de uma maneira generalizada" representa 33,33\% das ocorrências selecionadas e "de uma maneira geral" 66,66\%. Vejamos como tais operadores de generalização aparecem nos fragmentos dos artigos 25.66.2 e 26.67.4:

De uma maneira geral, os estudos têm apontado na direção de que a adoção dos IFRS aprimora a qualidade da informação contábil (Soderstrom \& Sun, 2007). Contudo, no que se refere à relevância informacional do lucro contábil, tal qual aqui investigada, observam-se resultados divergentes, sobretudo em relação ao value relevance, um dos atributos mais pesquisados pela maioria dos estudos. [grifo nosso]. (Artigo 25.66.2, Tópico 2.2, § 1ํㅜ , p. 230).

Também em um nível multijurisdicional, Ahmed, Chalmers, e Khlif (2013) constataram, de uma maneira generalizada, um aumento na associação (value relevance) entre o lucro contábil e o preço das ações, porém verificaram que o nível de associação apresentado pelo patrimônio líquido não sofreu alterações no período pós-IFRS. Resultados que se mantiveram mesmo após o controle dos efeitos dos fatores institucionais dos países analisados. [grifo nosso]. (Artigo 25.66.2, Tópico 2.2, § 6으, p. 230).

Por fim, de uma maneira geral, os resultados indicam que os IFRS aprimoraram a capacidade associativa do $\mathrm{LPA}_{\mathrm{it}}$, não sendo possível, dessa forma, rejeitar a hipóteses H1. Essa constatação está de acordo com o que sugere a literatura e, especificamente, alinhada aos resultados obtidos por Barth et al. (2008), Lima (2010), Costa (2012) e Macedo et al. (2013). [Grifo nosso]. (Artigo 25.66.2, Tópico 4.1, § $23^{\circ}$, p. 236).

A utilidade das demonstrações financeiras depende, fundamentalmente, da relevância das informações que são divulgadas aos usuários. De maneira geral, a informação contábil pode ser dita relevante quando possui algumas características, tais como: (i) contribui para a redução da assimetria informacional existente entre os usuários internos (gestores, executivos etc.) e os usuários externos da empresa (acionistas, credores, governo etc.); (ii) auxilia o usuário na avaliação dos efeitos potenciais de transações passadas, presentes e futuras nos fluxos de caixa futuros (valor preditivo) e/ou confirmando ou corrigindo suas avaliações anteriores (valor confirmatório); (iii) faz com que a decisão do usuário seja alterada pela sua utilização, ou seja, o usuário toma uma decisão diferente da que teria tomado, caso não tivesse determinada informação. (Artigo 26.67.4, Tópico 1, § 1ํㅜ p. 58).

De forma geral, os resultados mostram que o processo de mudanças do padrão contábil no Brasil está trazendo conteúdo informacional às demonstrações financeiras em relação ao mercado de capitais, ou seja, a exigência da DVA melhora a qualidade informacional das demonstrações financeiras. Isso está em consonância com os resultados de Bartov et al. (2005); Hung e Subramanyam (2007), Barth et al. (2008); Chalmers et al. (2008); Morais e Curto (2009), Chalmers et al. (2009), Kadri et al. (2009) e Lima (2011), que também encontraram melhoria do conteúdo informacional das demonstrações contábeis após o processo de convergência às normas internacionais de contabilidade. [Grifo nosso]. 
(Artigo 26.67.4, Tópico 6, § 6ํㅜ , p. 67).

Examinando o operador “de maneira geral” no artigo 26.67 .4 (Tópico 1, § 1ํ, p. 58) podemos verificar que é a única não atrelada a um ato de fala de autoridade científica. Todavia, interpretamos que ao expressar a generalização por meio do operador "de maneira geral", o comprometimento e responsabilidade que os autores têm sobre a assertiva é minimizada pelo termo "algumas". Ao afirmar que 'de maneira generalizada' que a informação relevante deve possuir "algumas" das características, especificadas em seguida, o autor não minimiza sensivelmente sua responsabilidade sobre a abrangência, sem perder de vista a potencialidade que tais especificações têm de se identificarem com as informações contábeis.

Nos outros casos apresentados podemos afirmar que as argumentações de generalização ou extensão têm como característica o respaldo em ato de fala de outros autores - citação indireta ou intertexto manifesto conforme Fairclough (2008) - tais atos de fala possuem autoridade científica e fundamentam essas generalizações. Desta maneira, os autores dividem a responsabilidade pela assertiva e expressam o cuidado/preocupação que têm em relação a esse tipo de argumento no texto científico. Pensamos que essa preocupação pode ser um dos motivos que restringe o emprego desse tipo de argumento nos artigos analisados, ao fazê-lo, os autores se cercam de cuidados a fim de que a generalização se dê de maneira fundamentada. Vale destacar que, se por um lado o termo confere abrangência do ato de fala ao qual se refere, por outro ele também revela certa superficialidade à afirmação dado que as generalizações acabam por fazer emergir as exceções, quando afirmamos "de uma maneira geral" estamos também admitindo que existam casos que não são contemplados pela generalização.

Ressaltamos que os operadores de generalização que evidenciamos no artigo 25.66.2 e 26.67.4 fazem referência a resultados de pesquisa que são base para a investigação que os autores realizaram e não dizem respeito, portanto, a abrangência dos resultados encontrados pelos autores dos artigos que são corpus de nossa investigação.

A Figura 17 nos permite uma analogia sobre a utilização dos operadores argumentativos utilizados nos artigos 25.66.2 e 26.67.4. 


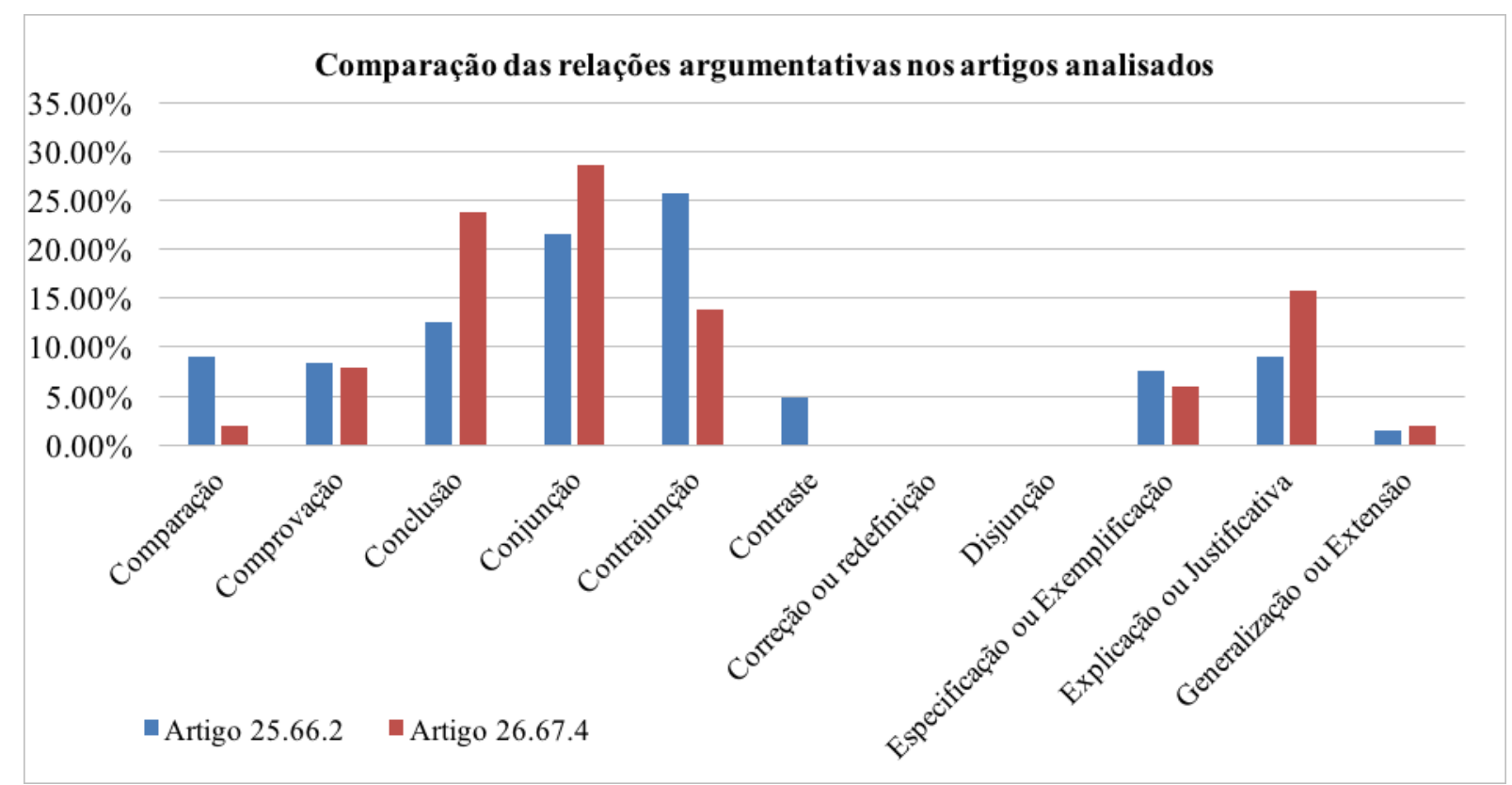

Figura 17. Comparação das relações argumentativas nos artigos analisados.

Podemos perceber que as argumentações que exprimem conjunção, contrajunção e conclusão são as mais utilizadas pelos autores dos artigos analisados (25.66.2 e 26.67.4). Em nossa opinião, há argumentações acessórias aos textos científicos como as comprovações/conformidade, exemplificações/especificações, explicações/justificativas e a comparações e outras que, além de permitirem a coesão, evidenciam as ideologias e concepções dos autores, favorecem ao diálogo e a reflexão entre o consumidor do texto e o autor do discurso que dele emerge. Todavia, somos de opinião que o emprego equivocado e descomedido dessas argumentações pode comprometer sobremaneira a comunicação, gerando ruídos e fragilizando a profundidade dos argumentos decorrentes do texto.

Apesar das regras que norteiam o texto científico não podemos negligenciar em relação a sua qualidade, uma vez que se trata de um discurso que tanto é modificado como capaz de modificar o meio. A escrita e divulgação do texto científico torna-se oportunidade de fomentar/estreitar laços e promover mudanças sociais a partir do poder de persuasão que possui e da autoridade científica que lhe é conferida.

Considerando as descrições dos operadores argumentativos feitas por Koch (2010) não constatamos, dentre os operadores selecionados, aqueles que conferissem ao texto um argumento de "correção ou redefinição" e de "disjunção", conforme relatamos anteriormente. Destacamos que, em nossa opinião, a conjunção foi o operador de argumentação mais usado porque tem a potencialidade de ligar atos de fala que se agregam em torno de outro tipo de argumento como, por exemplo, da conjunção atrelada a um argumento de conclusão ou contradição. O resumo dos operadores por artigos e o total em ambos os artigos está 
sumarizado na Tabela 21 a seguir:

Tabela 21:

Ocorrência dos operadores argumentativos no corpus examinado.

\begin{tabular}{llcrrrrr}
\hline & \multirow{2}{*}{ Operador } & \multicolumn{2}{c}{ Artigo 25.66.2 } & \multicolumn{2}{c}{ Artigo 26.67.4 } & \multicolumn{2}{c}{ Total } \\
\cline { 3 - 8 } & & Ocorrências & \% & Ocorrências & \% & Ocorrências & \% \\
\hline A & Conjunção & 31 & 21,53 & 29 & 28,71 & 60 & 24,49 \\
B & Disjunção & 0 & 0,00 & 0 & 0,00 & 0 & 0,00 \\
C & Contrajunção & 37 & 25,69 & 14 & 13,86 & 51 & 20,82 \\
D & Explicação & 13 & 9,03 & 16 & 15,84 & 29 & 11,84 \\
E & Comprovação & 12 & 8,33 & 8 & 7,92 & 20 & 8,16 \\
F & Conclusão & 18 & 12,50 & 24 & 23,76 & 42 & 17,14 \\
G & Comparação & 13 & 9,03 & 2 & 1,98 & 15 & 6,12 \\
H & Generalização & 2 & 1,39 & 2 & 1,98 & 4 & 1,63 \\
I & Exemplificação & 11 & 7,64 & 6 & 5,94 & 17 & 6,94 \\
J & Contraste & 7 & 4,86 & 0 & 0,00 & 7 & 2,86 \\
\hline Total & & 144 & 100,00 & 101 & 100,00 & 245 & 100,00 \\
\hline
\end{tabular}

As informações da Tabela 21 nos permite inferir que o corpus analisado é constituído basicamente de argumentos de conjunção (24,49\%), contrajunção (20,82\%), conclusão $(17,14 \%)$ e explicação $(11,84 \%)$. Os operadores de comprovação, comparação e exemplificação foram utilizados como complementares e reforçam os argumentos apresentados por meio dos operadores que possuem maior representação no texto.

As observações que relatamos, até então, revelam elementos que nos permitem inferir que o discurso apresentado no artigo 25.66.2 e 26.67.4 reflete necessidade contínua de amparo referencial - seja pela conclusão decorrente de oração anterior, seja pela adição de ideias, seja pela exemplificação/comprovação sobre afirmações anafóricas, típico da escrita de textos científicos. Todavia, esse amparo referencial tem sufocado/castrado a possibilidade de críticas mais contundentes ou que acarretem em incomodo intelectual aos consumidores do texto. Como dissemos anteriormente, a formação discursiva indica o que pode e o que deve ser dito em função da sua ideologia (Fairclough, 2008). Dessa maneira, o seu significado se consubstancia em uma construção que reflete a maneira pela qual o indivíduo percebe o mundo a sua volta.

Desta maneira, os pesquisadores atendem as expectativas de um modo hegemônico de fazer ciência. Propaga-se uma concepção na qual a criticidade e a reflexão é "fruto proibido" em matéria de textos científicos ou que arriscar-se em fazê-lo pudesse comprometer a aceitação e, conseguinte, disseminação do material produzido. Os encadeadores adversativos que capazes de gerar certa expectativa argumentativa e reflexão por do consumidor do texto foram utilizados de forma frágil/equivocada - elas remetem muito mais a ideia de conjunção/interligação que contraposição, além disso, acabam por não cumprir sua genuína 
função textual acarretando em uma argumentação rasa para um texto científico.

Deslocando o foco de análise dos operadores argumentativos para outros aspectos do texto, destacamos que o artigo apresenta aspectos relevantes e oportunos à nossa discussão. Na Introdução do artigo 25.66.2, chamou-nos à atenção a seguinte afirmação: “. . . não discute aspectos acerca de como essa informação deveria ser, mas sim, busca avaliar o quão útil ela é (ou aparenta ser) sob a perspectiva dos participantes do mercado acionário brasileiro" (Tópico $1, \S 8^{\circ}$, p. 229). Entendemos que o uso do conectivo de contrajunção "mas" seguido da palavra "sim" torna a mudança de opinião e/ou desejo expressa pelo conectivo contrastante "mas" mais enfática. Em seguida, os autores acrescentam a expressão entre parênteses e em grifo "ou aparenta ser". Este ato de fala nos traduz certa ironia dos autores, uma vez que se coloca como duvidosa a possibilidade de que a informação contábil produzida seja, de fato, útil aos usuários do mercado acionário.

Identificamos estrangeirismos no texto, ou seja, de palavras do idioma inglês na língua portuguesa "ajust", "code law", "dummies", "dummy", "pooled, "value" e "relevance" no artigo 25.66.2 e "corporate", "report", "pooling", "proxy", "p-value" e "value" e "relevance" no artigo 26.67.4. Analisamos, ainda, a polaridade semântica das palavras que o compõe, conforme Tabela 22, a seguir: 
Tabela 22:

Palavras com polaridade positiva encontradas no artigo 25.66 .2 da $R C \& F$.

\begin{tabular}{|c|c|c|c|c|c|}
\hline Palavras & Quantidades & Palavras & Quantidades & Palavras & Quantidades \\
\hline Acentuada & 1 & Forte & 2 & Relevância & 20 \\
\hline Acentuadas & 1 & Fundamentais & 1 & Relevante & 1 \\
\hline Adequado & 2 & Fundamental & 2 & Relevance & 9 \\
\hline Adicionalmente & 3 & Importante & 5 & Relevantes & 1 \\
\hline Ajuste & 8 & Importantes & 2 & Satisfatório & 3 \\
\hline Alta & 1 & Incentivos & 1 & Sensivelmente & 4 \\
\hline Altamente & 9 & Independência & 1 & Significância & 22 \\
\hline Alto & 1 & Informativos & 1 & Significante & 15 \\
\hline Aprimoramento & 1 & Interessantes & 1 & Significantes & 5 \\
\hline Apropriada & 2 & Lucro & 66 & Significativa & 1 \\
\hline Apropriado & 2 & Lucros & 5 & Significativos & 4 \\
\hline Atual & 1 & Magnitude & 13 & Sobretudo & 5 \\
\hline Aumento & 7 & Maior & 28 & Superior & 5 \\
\hline Avanços & 1 & Maiores & 1 & Superiores & 4 \\
\hline Bom & 2 & Maioria & 5 & Tempestivas & 2 \\
\hline Capacidade & 29 & Mais & 21 & Tempestividade & 30 \\
\hline Competência & 1 & Melhor & 1 & Tempestivo & 2 \\
\hline Desenvolvimento & 2 & Melhoria & 2 & Tempestivos & 1 \\
\hline Diversos & 4 & Motivações & 1 & Úteis & 2 \\
\hline Elevado & 3 & Novo & 1 & Útil & 1 \\
\hline Emblemáticas & 1 & Objetividade & 1 & Utilidade & 4 \\
\hline Especial & 1 & Poder & 14 & Utilizada & 1 \\
\hline Estabilidade & & Positivamente & 1 & Utilizadas & 1 \\
\hline Explicativo & 2 & Positivo & 5 & Utilizados & 3 \\
\hline Favorável & 14 & Positivos & 2 & Value & 9 \\
\hline Fidedignidade & 2 & Profundidade & 1 & Verificabilidade & 1 \\
\hline Fluidez & 1 & Qualidade & 13 & & \\
\hline
\end{tabular}

Em nossa seleção classificamos 80 palavras com polaridade semântica positiva no artigo 25.66.2 que em função das repetições totalizaram 450 palavras em todo artigo. A palavra mais citada com polaridade positiva foi "lucro", citada 66 vezes $(14,60 \%)$, seguida de "tempestividade" citada 30 vezes $(6,64 \%)$, "capacidade" citada 29 vezes $(6,42 \%)$, "maior" citada 28 vezes (6,19\%), "significância" 22 vezes (4,87\%), "mais" citada 21 vezes $(4,65 \%)$ e relevância citada 20 vezes $(4,42 \%)$. A polaridade, conforme vimos, é uma das dimensões do significado das palavras e corresponde ao emprego culturalmente determinado das palavras no caso do artigo em exame verificamos que os estrangeirismos são expressões com polaridade positiva e de frequência significativa nos textos. Há também neste artigo um total de 29 palavras com polaridade negativa que repetidas totalizaram 107 palavras com polaridade negativa, conforme Tabela 23: 
Tabela 23:

Palavras com polaridade negativa artigo 25.66.2 da $R C \& F$

\begin{tabular}{lclc}
\hline \multicolumn{1}{c}{ Palavras } & Quantidades & \multicolumn{1}{c}{ Palavras } & Quantidades \\
\hline Ausência & 6 & Negativos & 5 \\
Baixa & 4 & Nenhum & 3 \\
Declínio & 3 & Nenhuma & 1 \\
Divergentes & 3 & Perdas & 1 \\
Fraca & 1 & Poucas & 2 \\
Fragilidade & 1 & Prejudicial & 1 \\
Menos & 3 & Quebra & 6 \\
Mínimo & 1 & Quebras & 1 \\
Mínimos & 1 & Redução & 4 \\
Não & 55 & Rejeição & 5 \\
\hline
\end{tabular}

Identificamos que a palavra com polaridade negativa mais citada foi "não" (51\%) do total de palavras com polaridade negativa, seguida de "ausência" e "quebra" 6\% do total cada e "rejeição" e "negativos" 5\% do total. Podemos inferir que o texto apresenta uma quantidade maior de palavras com polaridade positiva, este aspecto também é característico da argumentação e do poder de persuasão que o texto pretende imprimir sobre o seu consumidor.

Evidenciamos no texto do artigo 26.67.4, Tabela 24, 62 palavras com polaridade semântica positiva, todavia por conta das repetições há um total de 393 palavras com polaridade positiva neste artigo. A palavra mais citada com polaridade positiva foi "valor", citada 67 vezes (17,05\%), seguida de "adicionado" citada 49 vezes (12,47\%), "riqueza" citada 32 vezes $(8,14 \%)$, "relevância" citada 30 vezes (7,63\%), "lucro" citada 21 vezes $(5,34 \%)$, "relevante" 18 vezes $(4,58 \%)$ e "mais" citada 17 vezes $(4,33 \%$ do total). 
Tabela 24:

Palavras com polaridade positiva artigo 26.67.4 da $R C \& F$

\section{Palavras}

Acrescidas

Ademais

Adicionado

Aumentando

Aumento

Aumentos

Aumentou

Auxiliar

Benefício

Benefícios

Bom

Bonificações

Competente

Contribui

Contribuições

Enfatizar

Especialmente

Extremamente

Forte

Ganho

Ganhos

Grande

Grandes

Importância

Importante

Importantes

Lucro

Lucros

Maior

Maiores

Maioria
Quantidades

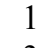

3

49

1

2

1

1

5

3

3

1

1

1

1

6

1

5

1

1

8

2

2

1

5

2

2

21

2

8

6

1

\begin{tabular}{l} 
Mais Palavras \\
Máximo \\
Melhor \\
Melhora \\
Melhores \\
Melhoria \\
Muitas \\
Muito \\
Perfeito \\
Persistência \\
Poder \\
Positiva \\
Qualidade \\
Receita \\
Relevância \\
Relevante \\
Relevantes \\
Retorno \\
Retornos \\
Riqueza \\
Significativa \\
Significativas \\
Significativamente \\
Suficientes \\
Superior \\
Superiores \\
Útil \\
Utilidade \\
Validação \\
Valor \\
Valores \\
\hline
\end{tabular}

\section{Quantidades}

17

1

10

5

6

1

2

2

1

2

5

1

1

2

30

18

3

7

3

32

6

1

4

1

3

1

1

5

1

67

7

Já no que diz respeito às palavras de polaridade negativa, selecionamos 8 no texto do artigo 26.67.4 8 que em decorrência das repetições totalizam 57 palavras. A palavra mais citada foi "não" 39 vezes $(68,42 \%)$, seguida de erro $9(15,79 \%)$ - as outras palavras tiveram baixa representatividade, conforme Tabela 25:

Tabela 25:

Palavras com polaridade negativa artigo 26.67.4 da $R C \& F$

\begin{tabular}{lc}
\hline Palavras & Quantidade \\
\hline Discordância & 1 \\
Erro & 9 \\
Menor & 2 \\
Menos & 2 \\
Minimamente & 1 \\
Não & 39 \\
Perda & 2 \\
Redução & 1 \\
\hline
\end{tabular}

Podemos afirmar que os artigos possuem uma tendência semântica de polaridade positiva, incluso, há duas palavras que são citadas com maior frequência em ambos os textos: 
"relevância" e "mais". Percebemos no texto algumas frases que possuem polaridade negativa, mas que se refletem na prática como aspectos favoráveis, a exemplo de "(v) reduzem a manipulação de informações contábeis (Ball, 2006)" [grifo nosso] (Tópico 2.1, § $2^{\text {o }}$, p. 229), bem como em “já Li (2010) constatou que as firmas da União Europeia que obrigatoriamente passaram a adotar os IFRS experimentaram uma redução de, aproximadamente, 47\% sobre o seu custo de capital”. Para Li (2010), tal redução justifica-se pela maior divulgação de informações financeiras e pela melhoria na comparabilidade da informação entre as firmas. E polaridade positiva, mas reflexos prejudiciais na prática como em "por outro lado, resultados divergentes são apontados por Callao, Jarne, e Laínez (2007), cujas evidências indicam que a adoção dos IFRS na Espanha não aprimorou a relevância dos relatórios financeiros para os participantes do mercado acionário local” (Tópico 2.2, § $7^{\circ}$, p. 230).

Tomemos agora para análise as palavras de uso mais frequentes. Na Tabela 26 temos que "IFRS" (9,45\%), "modelo" (6,14\%), "contábil" (5,89\%), "adoção" (5,72\%) e "lucro" $(5,22 \%)$ como as cinco palavras mais frequentes dentre as 50 mais citadas em todo o texto.

Tabela 26:

Palavras mais frequentes do artigo 25.66 .2 da revista $R C \& F$.

\begin{tabular}{lcclcc}
\hline \multicolumn{1}{c}{ Palavra } & Contagem & Percentual & \multicolumn{1}{c}{ Palavra } & Contagem & Percentual \\
\hline IFRS & 114 & $9,45 \%$ & Estimação & 15 & $1,24 \%$ \\
Modelo & 74 & $6,14 \%$ & Líquido & 15 & $1,24 \%$ \\
Contábil & 71 & $5,89 \%$ & Evidências & 14 & $1,16 \%$ \\
Adoção & 69 & $5,72 \%$ & Poder & 14 & $1,16 \%$ \\
Lucro & 63 & $5,22 \%$ & Significância & 14 & $1,16 \%$ \\
Período & 60 & $4,98 \%$ & Qualidade & 13 & $1,08 \%$ \\
Resultados & 49 & $4,06 \%$ & Dados & 12 & $1,00 \%$ \\
Efeitos & 37 & $3,07 \%$ & Normas & 12 & $1,00 \%$ \\
Informacional & 31 & $2,57 \%$ & Padrões & 12 & $1,00 \%$ \\
Firmas & 30 & $2,49 \%$ & Teste & 12 & $1,00 \%$ \\
Tempestividade & 28 & $2,32 \%$ & Variáveis & 12 & $1,00 \%$ \\
Capacidade & 26 & $2,16 \%$ & Avaliar & 11 & $0,91 \%$ \\
Coeficiente & 26 & $2,16 \%$ & Retorno & 11 & $0,91 \%$ \\
Informação & 26 & $2,16 \%$ & Valor & 11 & $0,91 \%$ \\
Conservadorismo & 24 & $1,99 \%$ & Estatística & 10 & $0,83 \%$ \\
Nível & 24 & $1,99 \%$ & Aumentou & 10 & $0,83 \%$ \\
Preço & 22 & $1,82 \%$ & Fixos & 10 & $0,83 \%$ \\
Maior & 21 & $1,74 \%$ & Painel & 10 & $0,83 \%$ \\
Significante & $1,66 \%$ & Patrimônio & 10 & $0,83 \%$ \\
Mercado & 20 & $1,66 \%$ & Países & 10 & $0,83 \%$ \\
Relevância & 20 & $1,66 \%$ & Superior & 10 & $0,83 \%$ \\
Ações & 20 & $1,58 \%$ & Análise & 9 & $0,75 \%$ \\
Transição & 19 & $1,49 \%$ & Relevance & 9 & $0,75 \%$ \\
Associação & 18 & $1,24 \%$ & Total & 9 & $0,75 \%$ \\
Contábeis & 15 & Value & 9 & $0,75 \%$ \\
\hline & 15 & & & & \\
\hline
\end{tabular}

A partir da análise do léxico identificamos que as palavras mais utilizadas no texto remetem às ciências humanas ou às ciências exatas, mais especificamente, ao âmbito contábil, 
político/administrativo, econômico/financeiro e matemático/estatístico.

Há também ocorrência frequente dos estrangeirismos, referidos anteriormente, representado apropriação habitual de vocabulário da língua inglesa como se fossem da língua portuguesa: "code", "law", “pooled", “dummies", “dummy", "relevance" e "value", sendo que estas duas últimas constam da lista das 50 palavras mais frequentes que são, conforme destacado na Tabela 26 . Podemos, ainda, ilustrar essa frequência de palavras por meio da nuvem a seguir (Figura 18), nela podemos identificar o direcionamento das discussões que o texto oferece e, se a tomarmos junto ao objetivo proposto e as hipóteses de pesquisa elaboradas, verificaremos o quão alinhado eles se encontram.

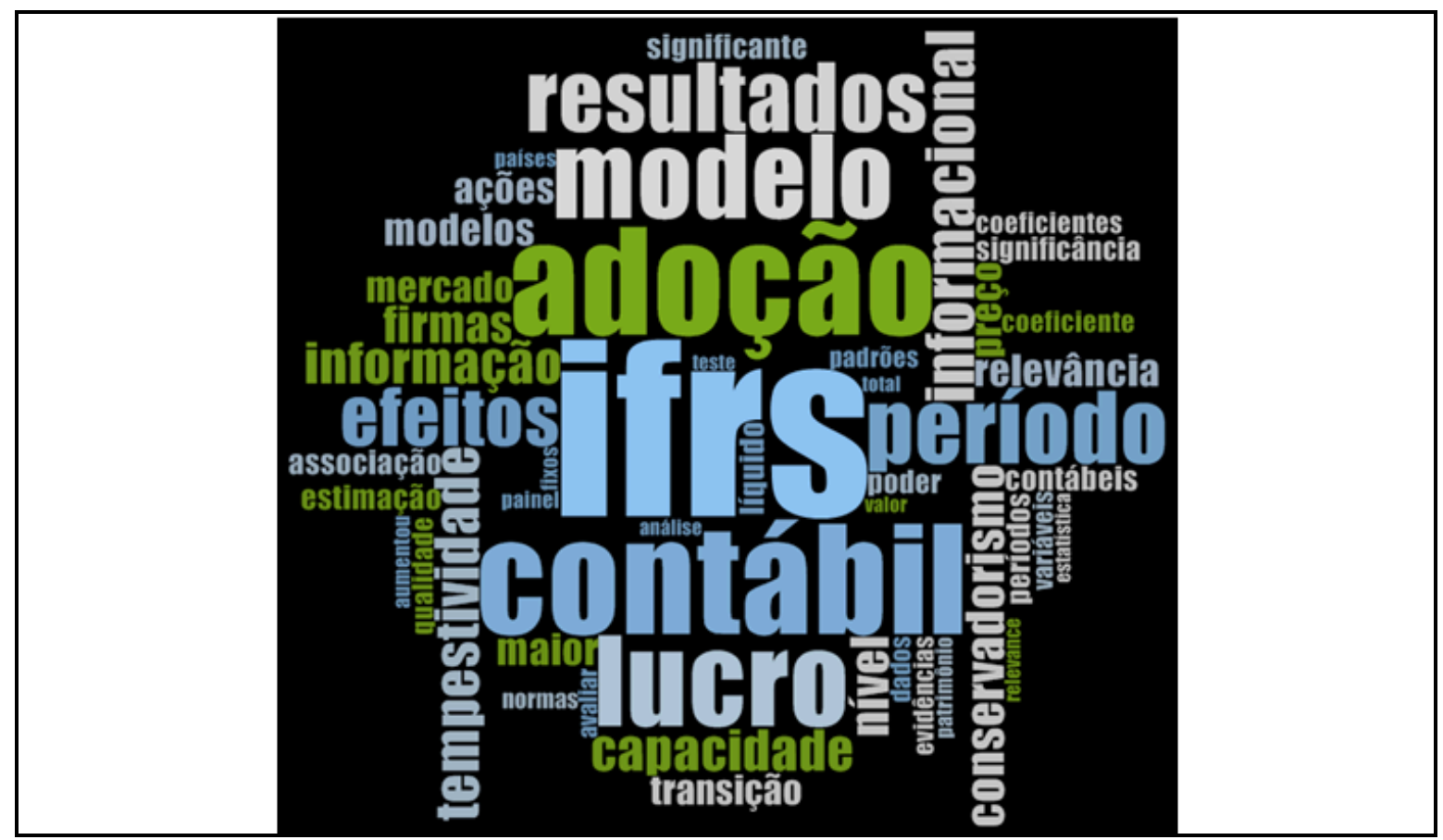

Figura 18. Nuvem com as 50 palavras mais frequentes do artigo 25.66.2.

A sigla IFRS e as palavras "contábil", "adoção", "modelo", "lucro", "resultados", "período", “efeitos", “informacional”, “tempestividade", “conservadorismo", “capacidade", "informação" e "firmas" são, nesta ordem, aquelas que mais se sobressaem na nuvem de palavras (Figura 18). A análise da nuvem de palavras nos oportuniza uma visão acerca da discussão central do texto, bem como daquelas que se encontram interligadas e são auxiliares no processo de argumentação. Notamos ainda, a incidência de termos que nos inspirou a criarmos quatro categorias de léxico, a saber: léxico político/administrativo; léxico matemático/estatístico; léxico econômico/financeiro e léxico contábil. A Tabela 27, a seguir, nos permite evidenciar os termos e suas respectivas frequências no âmbito de cada classificação: 
Tabela 27:

Classificação das palavras mais frequentes no artigo 25.66 .2 de acordo com campo léxico.

\begin{tabular}{|c|c|c|c|c|c|c|c|}
\hline \multicolumn{2}{|c|}{ Contábil } & \multicolumn{2}{|c|}{ Matemático/Estatístico } & \multicolumn{2}{|c|}{ Político/Administrativo } & \multicolumn{2}{|c|}{ Econômico/Financeiro } \\
\hline Léxico & Quant & Léxico & Quant & Léxico & Quant & Léxico & Quant \\
\hline Conservadorismo & 24 & Aumentou & 10 & Adoção & 69 & Ações & 19 \\
\hline Contábeis & 15 & Coeficiente & 26 & Análise & 9 & Mercado & 20 \\
\hline Contábil & 71 & Dados & 12 & Associação & 15 & Preço & 22 \\
\hline Evidências & 14 & Efeitos & 37 & Avaliar & 11 & Retorno & 11 \\
\hline IFRS & 114 & Estatística & 10 & Capacidade & 26 & & \\
\hline Informação & 26 & Estimação & 15 & Firmas & 30 & & \\
\hline Informacional & 31 & Fixos & 10 & Normas & 12 & & \\
\hline Líquido & 15 & Maior & 21 & Padrões & 12 & & \\
\hline Lucro & 63 & Modelo & 74 & Países & 10 & & \\
\hline Patrimônio & 10 & Nível & 24 & Poder & 14 & & \\
\hline Relevância & 20 & Painel & 10 & Qualidade & 13 & & \\
\hline Tempestividade & 28 & Período & 60 & Transição & 18 & & \\
\hline & & Resultados & 49 & & & & \\
\hline & & Significância & 14 & & & & \\
\hline & & Significante & 20 & & & & \\
\hline & & Superior & 10 & & & & \\
\hline & & Teste & 12 & & & & \\
\hline & & Total & 9 & & & & \\
\hline & & Valor & 11 & & & & \\
\hline & & Variáveis & 12 & & & & \\
\hline Total & 431 & Total & 446 & Total & 239 & Total & 72 \\
\hline$\%$ & 36,28 & & 37,54 & & 20,12 & & 6,06 \\
\hline
\end{tabular}

A partir da Tabela 27 inferimos que, ainda que os percentuais sejam muito próximos, o léxico explorado no artigo 25.66.2 é mais relacionado ao campo matemático/estatístico (37, $54 \%$ ) que a própria área contábil (36,28\%). Em nossa opinião, este fato guarda relação com os métodos analíticos empregados e pode ser ratificado na leitura das imagens que compõe esse artigo (Figura 19): 


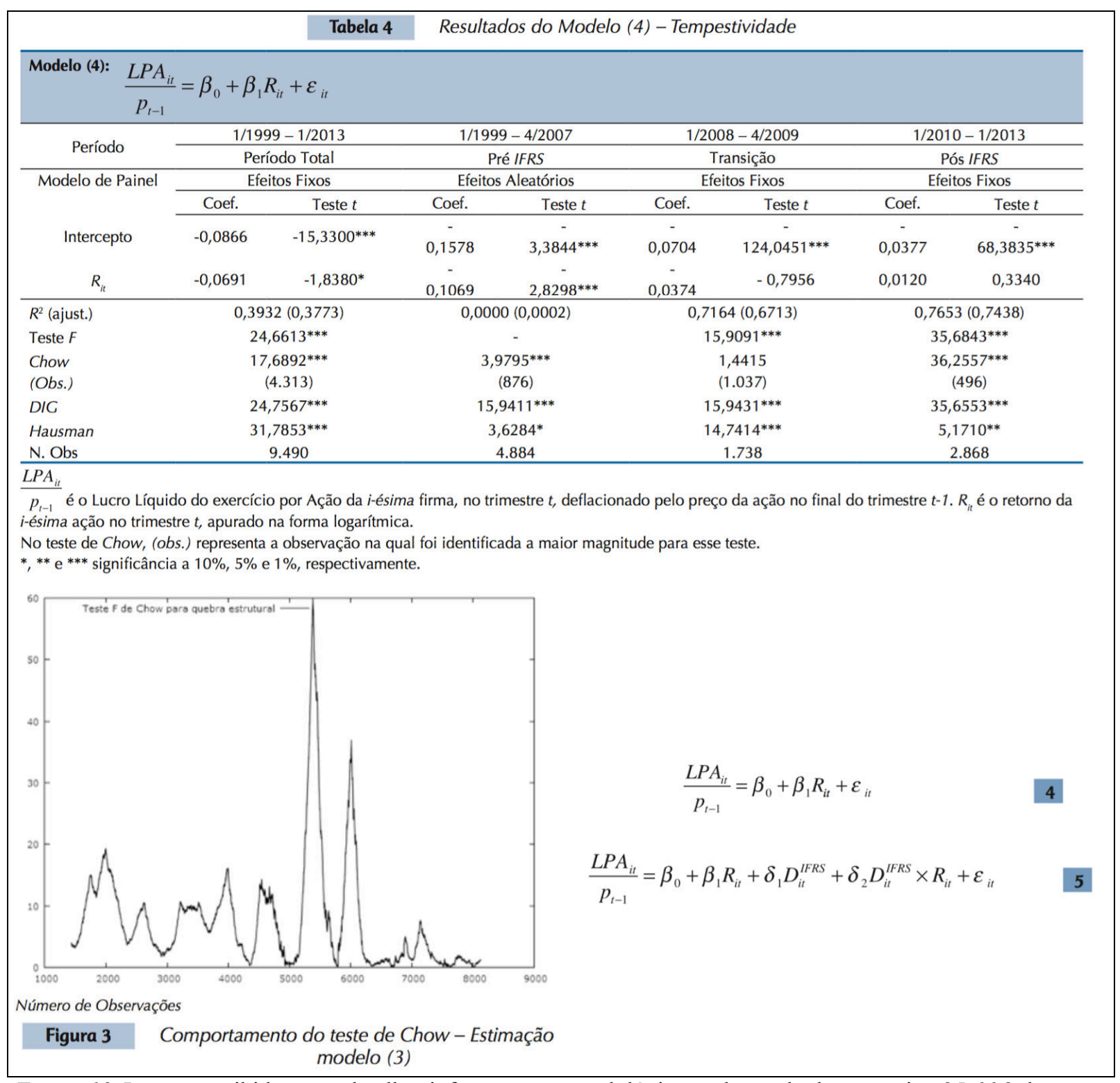

Figura 19. Imagens exibidas para detalhar informações metodológicas e de resultados no artigo 25.66.2 da RC\&F.

Evidenciamos nas imagens a forte relação com a linguagem matemática e estatística utilizada para a explicação do fenômeno em estudo. Em relação ao artigo 26.67.4, temos as palavras mais frequentes exibidas na Tabela 28, a seguir: 
Tabela 28:

Palavras mais frequentes do artigo 26.67.4 da revista $R C \& F$

\begin{tabular}{lcclcc}
\hline Palavra & Contagem & Percentual & \multicolumn{1}{c}{ Palavra } & Contagem & Percentual \\
\hline Valor & 91 & $6,57 \%$ & Equação & 24 & $1,73 \%$ \\
Value & 58 & $4,18 \%$ & Análise & 23 & $1,66 \%$ \\
Adicionado & 57 & $4,11 \%$ & Lucro & 23 & $1,66 \%$ \\
Accounting & 53 & $3,82 \%$ & Teste & 23 & $1,66 \%$ \\
Mercado & 44 & $3,17 \%$ & Brasileiro & 22 & $1,59 \%$ \\
Relevância & 41 & $2,96 \%$ & Journal & 21 & $1,52 \%$ \\
Empresas & 37 & $2,67 \%$ & Capital & 20 & $1,44 \%$ \\
Modelo & 37 & $2,67 \%$ & Variável & 20 & $1,44 \%$ \\
Informacional & 36 & $2,60 \%$ & Variáveis & 19 & $1,37 \%$ \\
Informação & 36 & $2,60 \%$ & Padrão & 18 & $1,30 \%$ \\
Líquido & 36 & $2,60 \%$ & Tabela & 17 & $1,30 \%$ \\
Relevance & 36 & $2,60 \%$ & Demonstrações & 17 & $1,23 \%$ \\
Contábil & 33 & $2,38 \%$ & Relevante & 16 & $1,23 \%$ \\
Contabilidade & 32 & $2,31 \%$ & Social & 15 & $1,15 \%$ \\
Estatística & 32 & $2,31 \%$ & Ajustado & 15 & $1,08 \%$ \\
Informações & 32 & $2,31 \%$ & Ação & 15 & $1,08 \%$ \\
Riqueza & 32 & $2,31 \%$ & Dados & 15 & $1,08 \%$ \\
Ações & $2,16 \%$ & Nível & 15 & $1,08 \%$ \\
Capitais & 30 & $2,16 \%$ & Período & 15 & $1,08 \%$ \\
Conteúdo & 30 & $2,09 \%$ & Regressão & 14 & $1,08 \%$ \\
Resultados & 29 & $2,09 \%$ & Analisar & 14 & $1,01 \%$ \\
Demonstração & 29 & $1,95 \%$ & Financial & 14 & $1,01 \%$ \\
Empresa & 27 & $1,95 \%$ & Objetivo & $1,01 \%$ \\
Preço & 27 & $1,88 \%$ & Processo & $1,01 \%$ \\
Contábeis & 26 & Financeiras & & $0,94 \%$ \\
\hline
\end{tabular}

As cinco palavras mais usadas dentre as cinquenta selecionadas pelo software Nvivo possuem a seguinte frequência: "valor" $(6,57 \%)$, value $(4,18 \%)$, adicionado $(4,11 \%)$, accounting $(3,82 \%)$ e mercado $(3,17 \%)$ - valores percentuais considerando o total das cinquenta palavras (Tabela 27). Notamos que a palavra valor, tanto em língua portuguesa quanto em língua inglesa, possui as maiores representações, vale destacar que dentre as cinco palavras mais citadas duas são estrangeirismos (accounting e value).

A Figura 21 apresenta a nuvem de palavras do artigo 26.67.4, podemos evidenciar que algumas palavras evidenciadas no artigo 25.66.2, se repetem nesta nuvem, a exemplo de resultados, ações, mercado, modelo, nível, período, normas, valor, dentre outras. 


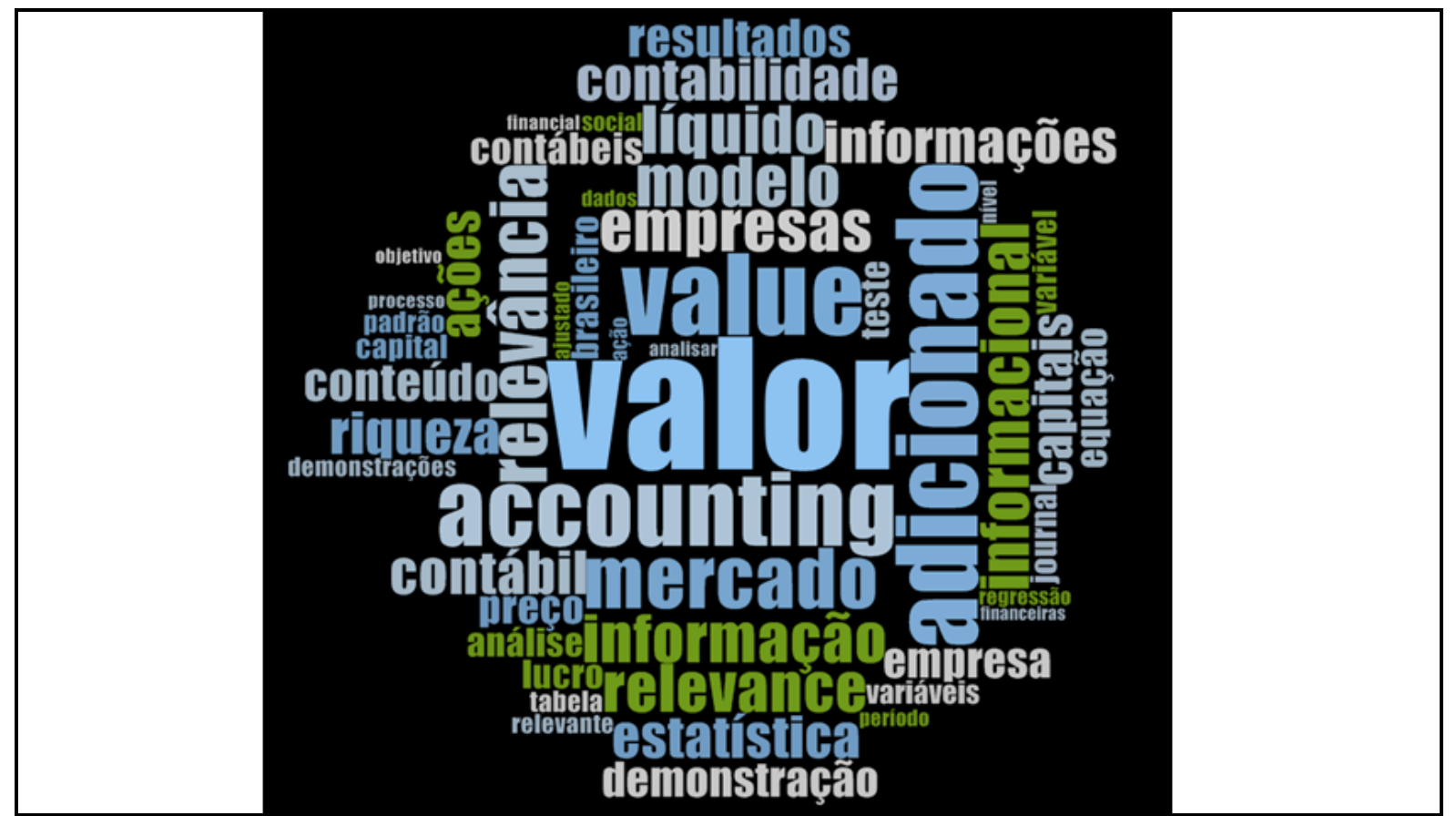

Figura 20. Nuvem com as 50 palavras mais frequentes do artigo 26.67.4.

Chamou-nos à atenção o fato de que significativa parcela das palavras mais citadas nos artigos 22.65.2 e 25.66.4, coincide como aquelas mais citadas na nuvem de palavras que representa as 50 mais citadas na perspectiva da linha de pesquisa "Contabilidade para usuários externos", fato este que nos permite inferir que o léxico da área sofre interferência de determinações culturais e este fato que pode ser ratificado por meio da Figura 21:

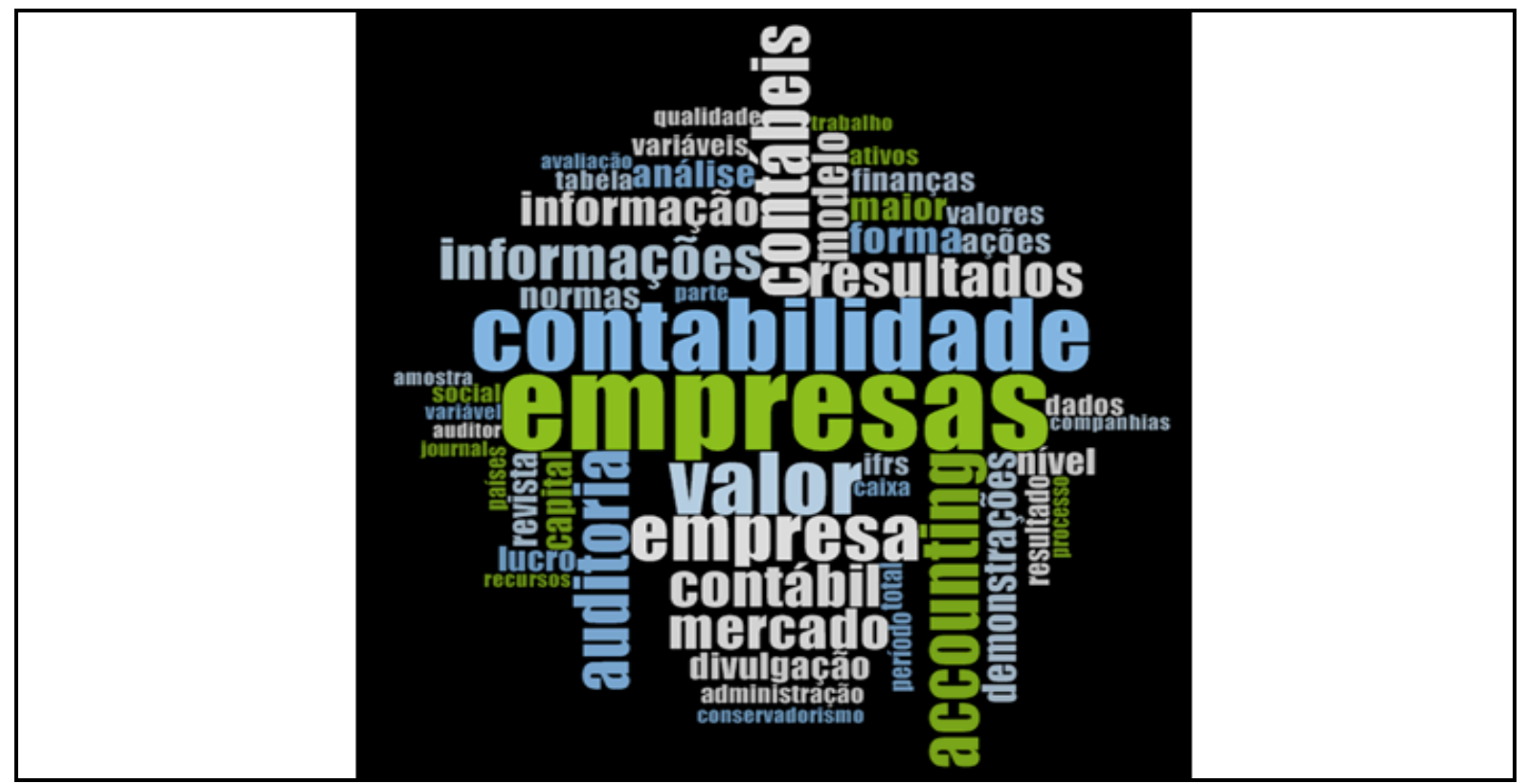

Figura 21. Nuvem com as 50 palavras mais frequentes nos artigos da "Contabilidade para usuários externos" publicados entre $2001-2015$. 
Os campos lexicais contábil, matemático/estatístico, político/administrativo e econômico financeiro, como no artigo 25.66.2, também aparecem no texto do artigo 26.67.4. Outro aspecto comum ao artigo anterior é que dentre 50 palavras mais usadas há uma frequência significativa de palavras mais vinculadas ao Léxico Matemático/Estatístico $(35,44 \%)$ que da área Contábil $(33,59 \%)$ - apesar de serem valores muito próximos.

Tabela 29:

Classificação das palavras mais frequentes no artigo 26.67 .4 de acordo com campo léxico

\begin{tabular}{|c|c|c|c|c|c|c|c|c|c|}
\hline \multicolumn{2}{|c|}{ Contábil } & \multicolumn{2}{|c|}{$\begin{array}{c}\text { Matemático/ } \\
\text { Estatístico }\end{array}$} & \multicolumn{2}{|c|}{$\begin{array}{c}\text { Político/ } \\
\text { Administrativo }\end{array}$} & \multicolumn{2}{|c|}{$\begin{array}{l}\text { Econômico/ } \\
\text { Financeiro }\end{array}$} & \multicolumn{2}{|c|}{ Outros } \\
\hline Léxico & Quant & Léxico & Quant & Léxico & Quant & Léxico & Quant & Léxico & Quant \\
\hline Accounting & 53 & Valor & 91 & Empresas & 37 & Mercado & 44 & Conteúdo & 29 \\
\hline Relevância & 41 & Value & 58 & Riqueza & 32 & Ações & 30 & Journal & 21 \\
\hline Informacional & 36 & Adicionado & 57 & Empresa & 27 & Capitais & 30 & & \\
\hline Informação & 36 & Modelo & 37 & Brasileiro & 22 & Preço & 26 & & \\
\hline Líquido & 36 & Estatística & 32 & Padrão & 18 & Análise & 23 & & \\
\hline Relevance & 36 & Resultados & 29 & Social & 16 & Ação & 15 & & \\
\hline Contábil & 33 & Equação & 24 & Analisar & 14 & Financial & 14 & & \\
\hline Contabilidade & 32 & Teste & 23 & Objetivo & 14 & Financeiras & 13 & & \\
\hline Informações & 32 & Variável & 20 & Processo & 14 & & & & \\
\hline Demonstração & 27 & Variáveis & 19 & & & & & & \\
\hline Contábeis & 25 & Tabela & 18 & & & & & & \\
\hline Capital & 20 & Ajustado & 15 & & & & & & \\
\hline Demonstrações & 17 & Dados & 15 & & & & & & \\
\hline Relevante & 17 & Nível & 15 & & & & & & \\
\hline & & Período & 15 & & & & & & \\
\hline & & Regressão & 15 & & & & & & \\
\hline
\end{tabular}

Tal fato também pode ser percebido, por exemplo, pelos textos imagéticos que o autor se utiliza para pormenorizar informações metodológicas e demonstrar resultados: 


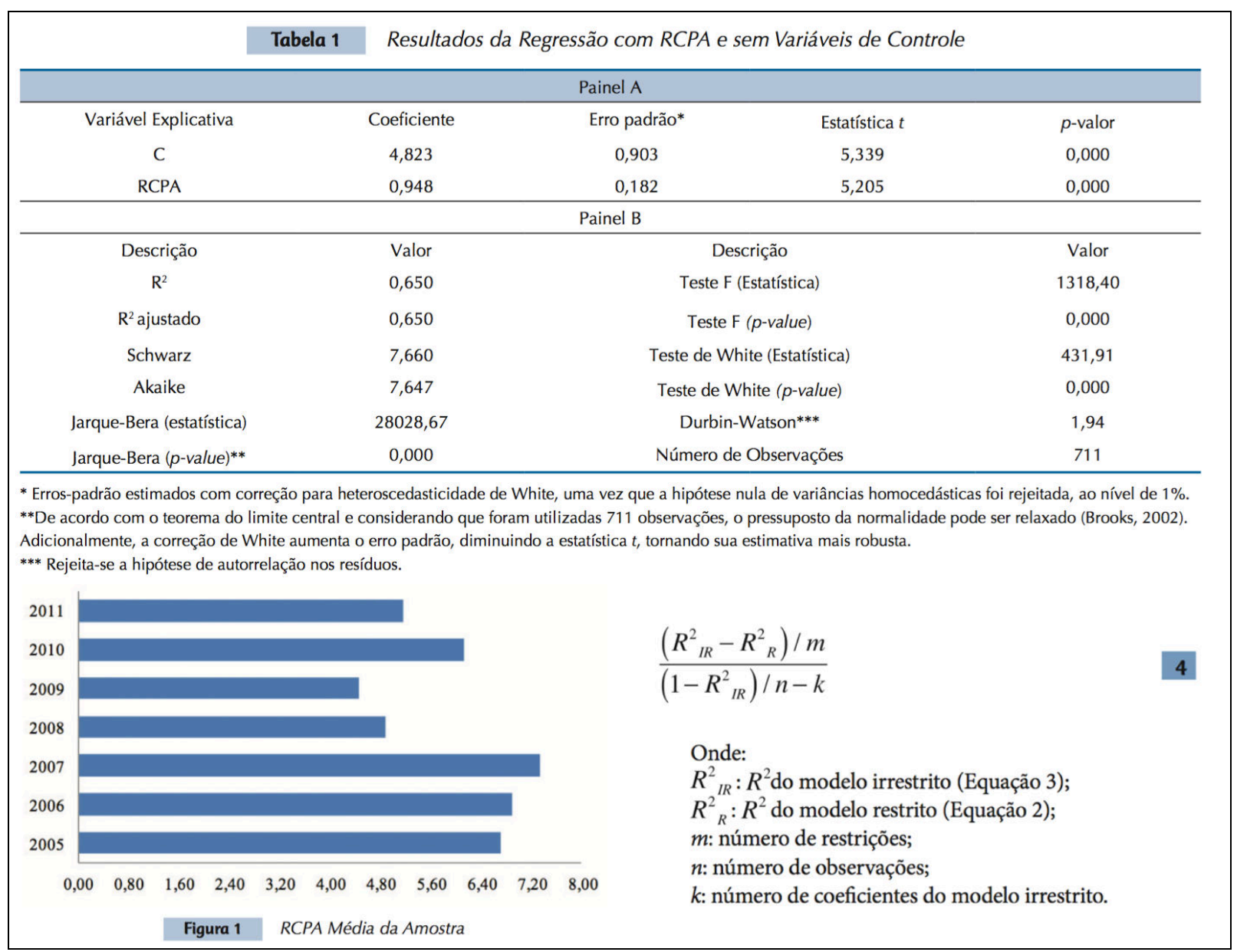

Figura 22. Imagens exibidas para detalhar informações sobre os resultados do no artigo 26.67.4 da RC\&F.

Podemos perceber nitidamente que os mecanismos da estatística e matemática se diluem harmonicamente com as informações comunicadas pelos artigos da contabilidade também por meio das imagens, estabelecendo o diálogo com um leitor direcionado/específico e/ou tornando "imperativa" a necessidade desses conhecimentos na formação do profissional contábil.

\subsection{Efeitos ideológicos da prática discursiva: a intertextualidade manifesta}

Ao concebermos o discurso científico na forma escrita como constituído por meio das relações socialmente estabelecidas e circunstanciado historicamente, podemos inferir que os textos escritos fazem emergir aspectos ideológicos e políticos que se refletem na concepção de mundo dos consumidores destes textos. Conforme vimos, Fiorin (1993) considera que a ideologia constitui uma forma de conceber o mundo que é expressa por meio da formação discursiva. $\mathrm{Na}$ área contábil, tais aspectos causam um efeito de reprodução e transformação na forma de pensar e conceber o texto científico que se enraízam as práticas discursivas de 
determinado grupo de intelectuais, criando regras hegemônicas de conceber ciência. Como ressaltamos na Introdução desta tese, acreditamos que essa reprodução tem como um dos fatores motivadores a busca por aceitação, prestígio e poder no ambiente acadêmico.

Fairclough (2008) afirma que o discurso materializa ideologia e cria identidade, interferindo na maneira como o indivíduo percebe o mundo e agindo sobre este mundo por meio das relações socialmente estabelecidas. Desta maneira, ao analisarmos a intertextualidade manifesta nos artigos 25.66 .2 e 26.67.4, conforme discutimos no Capítulo 2, buscamos compreender nos atos de fala as vozes deste discurso: os países de origem dos textos que foram utilizados como referencial teórico e os tipos de materiais que fundamentaram estes artigos - acreditamos que tais elementos guardam forte interferência sobre o discurso científico e determinam as ideologias que têm prevalecido até então.

Assim, no que diz respeito aos países de origem, representados por meio das pesquisas referenciadas (intertexto manifesto) no artigo 25.66.2 temos: Brasil (37,5\%), EUA (22,5\%), Holanda (15\%), Reino Unido (15\%) e Romênia, Canadá, China e Grécia (2,5\% cada). Já no artigo 26.67.4 evidenciamos que os trabalhos referenciados originaram-se do Brasil (45,71\%), EUA (18,57\%), Reino Unido (20,00\%), Holanda (12,86\%) e Austrália (2,86\%). Chamou-nos à atenção o fato de que a literatura internacional manifesta em ambos os artigos origina-se de dos países que possui realidade econômico-social muito distinta da brasileira. Tal fato coaduna os resultados que encontramos nas entrevistas quando os pesquisadores entrevistados afirmam que os nossos estudos trazem discussões que não têm significativa utilidade econômica e social ao nosso país, bem como com a análise de contexto quando fizemos a apreciação das fontes referenciais da linha hegemônica nos últimos seis anos - além da literatura nacional os países estrangeiros que mais referenciados são EUA, Reino Unido e Holanda, não necessariamente nesta ordem.

O exame dos intertextos manifestos, individualmente, nos permite inferir que o maior número de referências citadas em ambos os artigos é de publicação brasileira, mas se analisarmos a totalidade dos intertextos manifestos que aparecem nos artigos $22.56 .2 \mathrm{e}$ 26.67.4 perceberemos que há uma predominância de vozes internacionais que delineiam e dominam o discurso dos autores. Como contrajunções foram utilizadas na maioria dos casos de maneira equivocada, por se referirem a aspectos internos ao próprio texto, há prevalência de uma prática discursiva fundada em operadores de conjunção que organiza a tessitura de opiniões de um discurso nada brasileiro - consideramos essa situação como um agravante, principalmente diante da passividade crítica dos autores nacionais.

No que se refere ao tipo de material utilizado pelos autores para fundamentar a 
pesquisa, temos que a maior parte deles é constituída por artigos de periódicos online, ou seja, $72,5 \%$ e $60,50 \%$ das referências que fundamentam a investigação do artigo 25.66.2 e 26.67.4, respectivamente. Compreendemos que, se por um lado os trabalhos estão fundamentados em intertextos manifestos que trazem debates atuais, por outro, temos ratificada a fragilidade de contraposições teóricas evidenciadas na análise dos operadores e na concepção dos PEs já que os artigos da área contábil, em geral, são resultados de pesquisas empíricas, portanto raros são os que se utilizam de uma teoria para fundamentar as análises. Ademais, quando se trata de um intertexto internacional, o fato de se referirem a debates inerentes a um contexto social, político e econômico distinto, evidencia que as temáticas podem ser importantes, mas não tão significativas quanto tantas outras que poderiam ser discutidas em prol do desenvolvimento da área de conhecimento no país. Há o predomínio de um pensamento focado em pesquisas e problemas atuais, e pensamos que isto é um fator bastante positivo, contudo tal fato não justifica a "negligência" ou "desvalorização" da produção intelectual nacional e/ou de problemáticas que tragam efetivo benefício social, econômico e cultural ao país.

Chamou-nos à atenção o fato de que dentre as referências que compõem a intertextualidade dos artigos 25.66 .2 e 26.67.4 há cinco working papers publicados nos EUA (dois no artigo 25.66.2 e três no artigo 26.67.4). Ainda que estes trabalhos possuam um número representativo de consultas/acessos na web, sabemos que não se trata de material avaliado por um grupo de especialistas e não são publicações definitivas. Este aspecto deixa evidente a autoridade americana sobre a publicação brasileira, mesmo quando não se trata de publicação definitiva.

Além disso, temos que das 40 referências do artigo 25.66.2 há quatro livros: um sobre metodologia (estudo de caso), outro sobre técnicas estatísticas e mais dois sobre a contabilidade internacional - 50\% dos livros publicados são nacionais e 50\% são publicações do Reino Unido e EUA. No artigo 26.67.4 há uma situação que não é tão distinta, porque das 71 referências, treze são livros $(18,31 \%)$ - três deles relacionam-se às técnicas de análise estatística empregadas no estudo, e outro trata sobre metodologia da pesquisa; três livros discutem sobre teoria da contabilidade e seis livros técnicos e/ou normativos da área contábil. No caso deste último artigo, há três livros de publicação internacional: dois dos EUA e um do Reino Unido. Apesar de não ser na mesma proporção que no artigo anterior, os países de origem são os mesmos. Notamos também que, apesar de terem a temática "Informação Contábil" (AT.5.2) como eixo central de discussão e tratarem especificamente da "Relevância da Informação Contábil”, os artigos 25.66.2 e 26.67.4 possuem apenas duas referências em comum. Chamou-nos à atenção o fato de que as publicações em comum sejam artigos, cujos 
autores são Barth, M. E., Beaver, W. H., \& Landsman, W. R. (2001) e Barth, M. E., Landsman, W. R., \& Lang, M. H. (2008) publicados respectivamente nos periódicos Journal of Accounting and Economics (Holanda) e Journal of Accounting Research (Reino Unido). Em nosso entendimento, há dois agravantes: o primeiro diz respeito ao fato de que não há uma discussão teórica sobre a essência do termo "relevância" que decorra de autores comuns nos artigos 25.66.2 e 26.67.4; o segundo diz respeito ao fato de que não há um livro comum que discuta teoricamente sobre a essência do termo - apesar de evidenciarmos que o artigo 26.67.4 referencie três livros de teoria da contabilidade.

$\mathrm{O}$ artigo 22.65.2 tem como primeiro parágrafo de Introdução um discurso que anuncia as vantagens da convergência às normas internacionais no Brasil: "uma das mais importantes motivações para adoção dos International Financial Reporting Standards - IFRS é a comparabilidade da informação contábil entre os países" (Tópico 1, § 1ํㅡ, p. 229). Logo em seguida, há uma intertextualidade manifesta que evidencia a maneira de pensar de pesquisadores que publicaram no Brasil e EUA (Ball, 2006; Lima, 2010; Niyama, 2007), os quais afirmam: "busca-se estabelecer uma linguagem única para os mercados e um ambiente favorável a uma maior fluidez do fluxo de capitais". Percebemos que a adesão ao discurso dos autores apregoa a aderência a uma forma de pensar no local por meio do global/internacional - quando se fala em fluidez do fluxo de capitais evidencia-se que o objetivo primordial está na possibilidade de promover ambiente propício a transações econômico-financeiras.

Identificamos também o discurso normativo que se fundamenta na ideia de que observar as regras internacionais é condição favorável para a contabilidade brasileira. Essa ideologia é ratificada na frase seguinte quando os autores admitem essa postura fundamentando-se em pesquisas publicadas nos EUA e Reino Unido (Barth, Landsman, \& Lang, 2008; Leuz \& Wysock, 2008): “assume-se, assim, que os conceitos e os critérios de reconhecimento, mensuração e divulgação estabelecidos pelos IFRS oferecem uma qualidade informacional superior que implica na utilidade da informação contábil que é produzida" chamou-nos à atenção o fato de que os autores consideram qualidade "superior" aquela que decorre de uma equipe de agentes normatizadores internacionais. Percebe-se em todo o texto um discurso que induz o leitor a acreditar que as condições para adesão às normas internacionais se dão em contexto favorável: “outro fator positivo é o nível de desenvolvimento experimentado pelo mercado acionário brasileiro nos últimos anos. A reformulação da Lei das S.A. ocorrida em 2001; a estabilidade dos preços; a abertura comercial do mercado acionário", dentre outros aspectos fundamentando-se em estudo decorrente de uma tese publicada no Brasil. 
No artigo 25.66.2, os autores apresentam estudos brasileiros que encontraram resultados "divergentes" sobre o assunto para introduzir a lacuna que buscam preencher na discussão do tema, trazendo autores que publicaram nos EUA e Holanda para desvelar de maneira mais específica o significado da relevância informacional discutida - percebe-se que a ideologia dos pesquisadores citados se fundamenta no contexto do mercado acionário.

Os autores do artigo 25.66.2 apresentam, ainda, o conceito de "relevância" da informação contábil e "algumas características" que na opinião deles precisam ser percebidas para que a informação seja considerada relevante, apesar de enfatizarem que há uma variedade de sentidos para o termo no contexto da contabilidade. Em seguida, os autores especificam o sentido do termo relevante no texto "uma informação é considerada relevante se ela estiver correlacionada com os valores de mercado da empresa", concepção originada de uma publicação holandesa cujos autores são Barth, Beaver, e Landsman (2001) - o discurso de relevância relaciona-se como uma ideologia enraizada em concepções de mercado. Ainda na Introdução os autores se fundamentam em outros autores que publicaram em periódico holandês, Brown, Lo, e Lys (1999), para afirmar que "esses estudos, normalmente conduzidos pela aplicação de análises de regressão" - a análise do estudo se embasa em conhecimentos estatísticos e que tem a ideia de "relevância" é importada - citam-se Santos e Lustosa (2010) que são autores brasileiros, mas os autores do artigo 25.66 .2 equivocadamente não os referenciados.

O discurso da normatização também se faz presente no texto quando os autores discutem a questão da obrigatoriedade da Demonstração de Valor Agregado (DVA) “adicionalmente, a Lei 11.638/07 introduziu a obrigatoriedade da divulgação da Demonstração do Valor Adicionado (DVA) para as companhias abertas”, trazendo ao discurso a voz do legislador brasileiro e internacional ao citar o "International Accounting Standards Board (IASB)".

Ainda na Introdução, os autores destacam que não são comuns as discussões sobre a contabilidade como prática institucional e social. Para tanto, citam o intertexto manifesto de autores cuja pesquisa foi publicada no Reino Unido, Burchell, Clubb \& Hopwood (1985), para ratificar que "a relação da contabilidade com o social tende a ser indicada e presumida e não descrita e analisada" - notamos que esta ideologia tem se refletido nas publicações da linha "Contabilidade para usuários externos" em função das temáticas que são abordadas, conforme análise de contexto desenvolvida no Capítulo 3 desta tese. Compreendemos que os autores se utilizaram deste argumento como lacuna de pesquisa, dado que estudaram a DVA, mas há, concomitantemente, uma negação da sua importância nas discussões atuais incluso o 
caráter normativo internacional. Para aqueles que objetivam ingressar no mundo da pesquisa ou têm intenções de projetar-se internacionalmente, o estudo da DVA, possivelmente, não será objeto de interesse - como vimos, o artigo 25.66.2 também traz uma abordagem normativa centrada no IFRS.

Identificamos na Introdução do artigo 26.67 .4 o seguinte ato de fala: “... sabe-se que a inclusão de um novo demonstrativo obrigatório acarreta em aumento de trabalho e, consequentemente, custos decorrentes de sua elaboração, auditoria e publicação, justificando estudos que investiguem se a sua apresentação proporciona aos usuários benefícios, que podem ser induzidos pelo value relevance" (Tópico 1, $\S 12^{\circ}$, p. 59). Este discurso deixa evidente que os autores enfatizam o questionamento existente em relação ao custo e efetivo benefício que a obrigatoriedade de publicação da DVA pode gerar - em nossa opinião esta ideia é mais uma negação acerca da relevância do demonstrativo como instrumento de informação para os usuários da contabilidade, já que numa visão capitalista, em caso de dúvida sobre a importância dessa publicação, é melhor evitar o desperdício de esforços.

As interpretações que apresentamos evidenciam um discurso que se perpetua em todo o texto dos artigos 25.66.2 e 26.67.4. Laclau e Mouffe (1987) consideram que o discurso fundamenta hegemonia, porque ele é terreno primário que se estabelece por adesão ideológica e constitui uma realidade/significado. Desta maneira, entendemos que o discurso emergente dos artigos analisados revela prevalência de concepções normativas, focadas em análises quantitativas e abordagens mais econômicas e menos sociais.

\subsection{Discurso contábil nos artigos: perspectiva de pesquisadores}

Ao analisarmos os operadores argumentativos, pudemos evidenciar algumas fragilidades do discurso enunciado nos artigos examinados. Esta fragilidade decorre dos equívocos cometidos ao estabelecer tais argumentos uma vez que acarreta em pouca criticidade/reflexão, fato que entendemos como prejudicial para o desenvolvimento científico e da cultura escrita da área contábil.

Com o intuito de corroborar as inferências decorrentes destes achados, examinamos a concepção dos pesquisadores entrevistados (editores nacionais e internacionais, atualmente ex-editores e/ou membros do conselho editorial de periódicos que publicam exclusivamente na área contábil). Com base nestas entrevistas, pudemos identificar nas falas algumas categorias relacionadas a esse discurso, as quais configuram e atribuem identidade a esse discurso. Quando perguntamos aos pesquisadores entrevistados (PE) quais características 
atribuiriam ao discurso escrito, professado nos artigos científicos da área contábil, eles o consideram como: neutro, desestruturado logicamente, enviesado, descritivo, superficial, imaturo, descontextualizado, moldado, intuitivo e descomprometido.

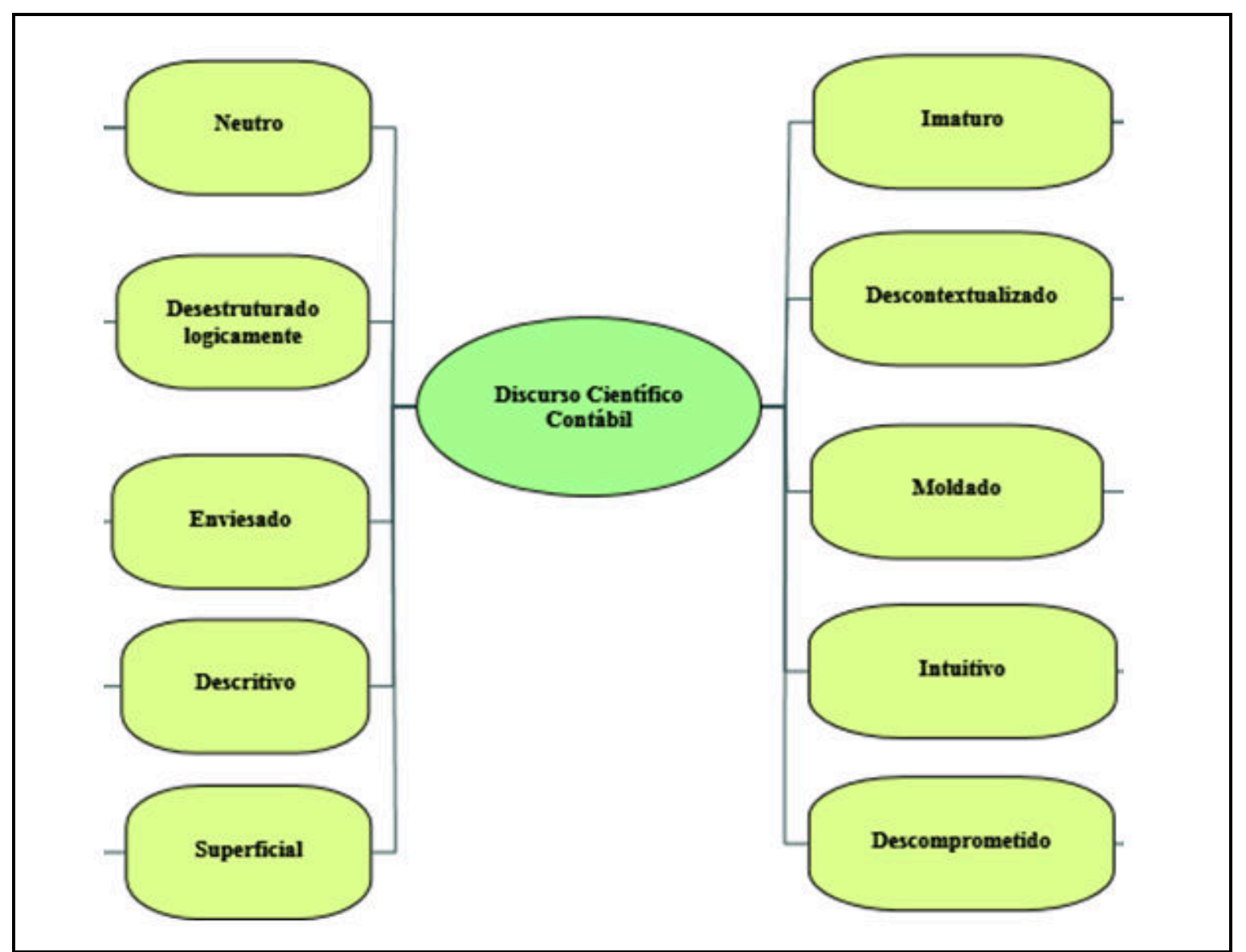

Figura 23. Características do discurso de textos científicos publicados no formato de artigos em periódicos contábeis.

A neutralidade foi citada nos discursos dos PEs relacionando-se, na maioria das vezes, a isenção e a linguagem impessoal imperativa aos textos científicos, conforme descrevemos na seção 3.4 desta tese. Todavia, segundo os PEs essa neutralidade - que entendemos como um posicionamento crítico decorrente de resultados de uma investigação científica organizada sistematicamente, ainda que flexível, e devidamente fundamentada - é confundida com isenção reflexiva e ausência de posicionamento crítico dos autores, como se a impessoalidade fosse marca para a ausência de criticidade e justificativa para delegação dessa responsabilidade discursivo-ideológica a outros autores que são citados no referencial teórico do corpo de um artigo (Figura 24). Pensamos que ser isento é apresentar os fatos tal qual eles se manifestam, e essa isenção não deve cercear a oportunidade de uma reflexão mais profunda sobre os resultados de uma pesquisa, muito pelo contrário. 
Os entrevistados enfatizaram também a desestruturação lógica dos textos (Figura 24) como uma das características da pesquisa contábil. Esta ideia foi explorada ao fazerem alusão ao excesso de termos desnecessários nas frases, que acabam prejudicando a organização lógica das ideias nos atos de fala. Já a ideia de texto enviesado, como atributo da pesquisa científica contábil, foi citada quando os PEs se referiram "só haver um lado da moeda", ou seja, uma profunda carência de contraposição de ideias nos textos, os quais mantêm conformidade com achados de pesquisas anteriores e, na melhor das hipóteses, buscam contribuir com uma opinião fundada em outras amostras ou modelo estatístico que, na visão dos autores do trabalho, é mais robusto - na maioria das vezes trata-se de pesquisa quantitativa.

Temos ainda, citados pelos entrevistados, os aspectos da descrição e da superficialidade (Figura 24). O texto enunciado no discurso dos artigos científicos da área contábil é descritivo porque, segundo os PEs, relatam sobre dados estatísticos, reproduzindo os números organizados no formato de tabelas, e buscam testar as hipóteses estatísticas, extraindo pouco do referencial teórico no momento da análise dos resultados. Logo, os PEs entendem que há negligência teórica e se extrai muito pouco do que os achados seriam capazes de revelar. 


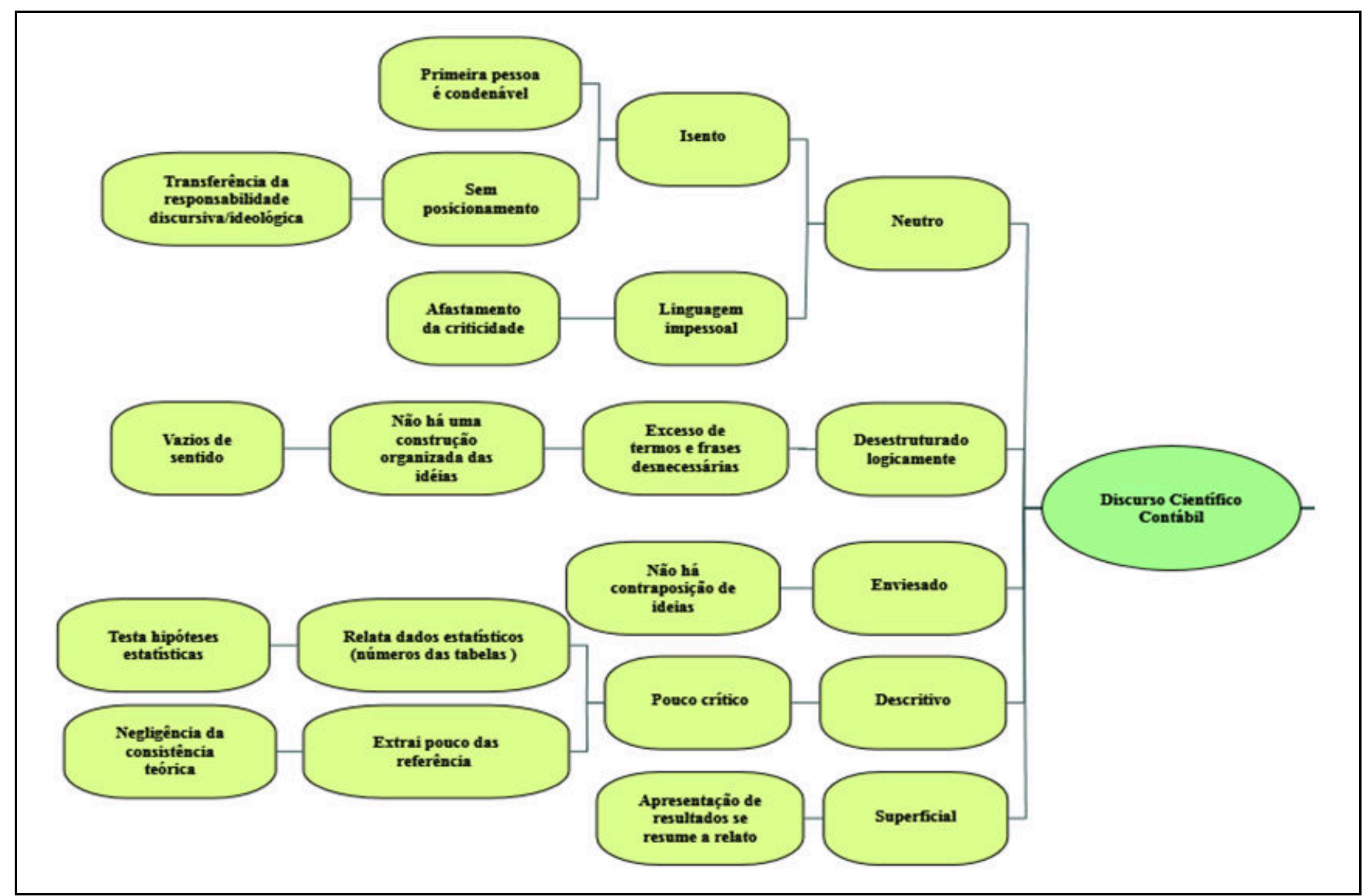

Figura 24. Característica do discurso científico contábil em artigos de periódicos da área e fatores que contribuem para essa característica 
$\mathrm{Na}$ Figura 25, temos o discurso científico considerado como imaturo, descontextualizado, moldado, intuitivo e descomprometido. A questão da imaturidade, na opinião dos PEs, decorre de dois fatores bastante pontuais: o primeiro é que há pouco tempo de dedicação à pesquisa, ou seja, os estudos não maturam o suficiente para que possam obter uma análise segura acerca dos achados. Este fato é fomentado e perpetuado pela pressão das IES por publicação - já que é um dos itens que compõem a sua avaliação - e acarreta também na dificuldade que se tem de refletir com profundidade sobre os achados, trazendo uma opinião que se caracterize como diferenciada/inovadora para a área de conhecimento. $\mathrm{O}$ segundo fator, também apontado pelos PEs, é a celeridade no processo de formação do pesquisador contábil, pois esta celeridade no processo de formação acaba por inibir a capacidade crítica - há certo receio/respeito crítico por parte do pesquisador iniciante, como se pensar diferente da "caixa" fosse pecado ou ousadia sem perdão, com condenação perpétua à marginalidade no mundo da disseminação científica. Neste contexto, o pesquisador iniciante se torna um "excelente" coletor de informações, mas não sabe o que fazer para transformar dados em informações úteis; essa imaturidade científica também se reflete na maneira como são apresentadas as argumentações no texto.

De acordo com os entrevistados, o discurso dos artigos científicos da área contábil foi também considerado descontextualizado (Figura 25). Na maioria das falas a opinião é de que essa descontextualização ocorre em virtude de que algumas pesquisas se distanciam da realidade social brasileira, comprometendo potenciais contribuições, bem como porque essas pesquisas não possuem identidade nacional e acabam por reproduzir uma hegemonia internacional. Os PEs também ressaltaram que algumas destas pesquisas priorizam a internacionalização do discurso em detrimento da contribuição para a área e para o desenvolvimento econômico e social do país. Nós entendemos que esta é uma situação preocupante, porque o estudo sobre temáticas contábeis que seguem modismos ou que têm o objetivo primordial de visibilidade internacional de maneira descomprometida com as necessidades da área fomenta e estabelece uma "fábrica" de desperdício intelectual e financeiro inútil e/ou o inoportuno.

No que diz respeito à questão do discurso produzido pela área contábil ser considerado moldado (Figura 25), temos que esta opinião não decorreu de uma observação sobre a estrutura do texto dos artigos científicos, mas do fato de que esse discurso é delimitado em “caixinhas de artigos" que não apresentam grande avanço no que diz respeito ao ato interdisciplinar ou transdisciplinar - poucos são os trabalhos que buscam analisar o objeto contábil à luz de teorias ou métodos não hegemônicos, mas que poderiam ser utilizados para 
obtenção de análises com base em outros prismas. Acreditamos que a maneira de pensar e elaborar os problemas científicos decorre da subjetividade do indivíduo e de sua formação como indivíduo e profissional e é influenciada pelos indivíduos e/ou grupos com os quais mantém relações. Assim, o que entendemos das respostas obtidas é que precisamos ampliar o olhar dos pesquisadores da área por meio de uma formação menos técnica e mais reflexiva. Afinal, enquanto a mudança se limitar à amostra da investigação ou ao tipo de modelo estatístico empregado, como tentativa de obter um resultado mais apurado, haverá homogeneidade dos resultados das pesquisas e pouca, ou nenhuma, inovação ou contribuição.

Quando se referiram a "intuitivo" e "descomprometido" (Figura 25), ao falarem do discurso científico, os PEs aludiram ao fato de que os trabalhos não se fundamentam em teorias e que, na maioria das vezes, os autores de trabalhos empíricos não fazem interface dos achados com o referencial teórico, por isso acabam por apresentar uma conclusão com base em suposições e intuições. Já a concepção de um discurso descomprometido vem do fato de que os trabalhos têm um fim em si mesmo, ou seja, geralmente são discursos elaborados para publicação em determinada revista e submissão a determinado congresso. Entendemos que o processo deveria focar-se na utilidade/contribuição, e como consequência na disseminação desse discurso por meio de debates em congresso e publicação definitiva em um periódico a fim de que os interessados possam fazer uso do conhecimento construído. 


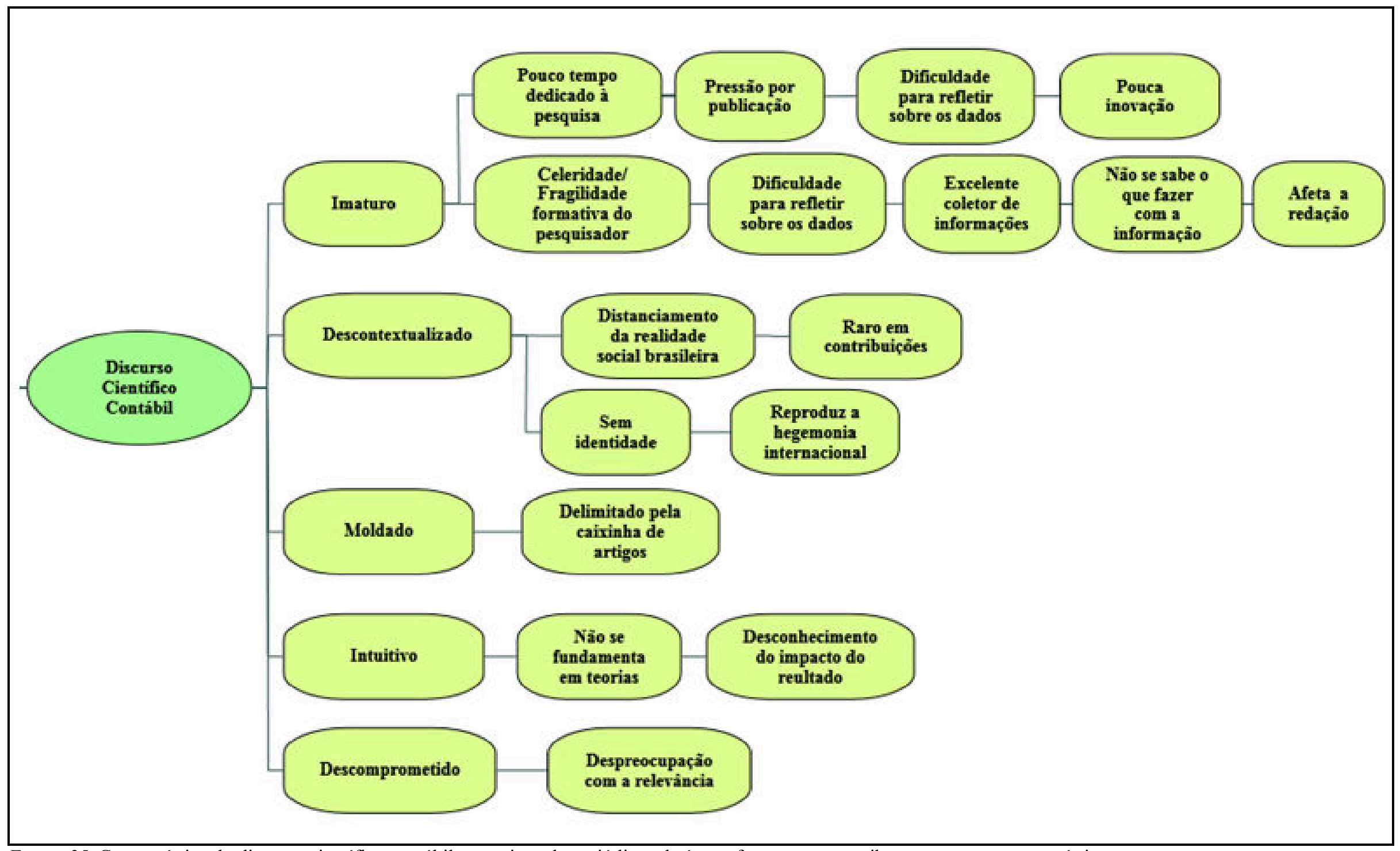

Figura 25. Característica do discurso científico contábil em artigos de periódicos da área e fatores que contribuem para essa característica. 



\section{CONCLUSÕES}

Esta investigação teve como objetivo conhecer algumas especificidades do discurso subjacente às publicações da área contábil a fim de verificar como elas contribuem para o que poderíamos chamar de cultura científica escrita da área. Assim, direcionamos nossa atenção ao léxico e às práticas argumentativas do discurso científico enunciado em artigos da área contábil, sobre a influência ideológica que ela exerce na área de conhecimento e sobre sua capacidade de representação e reprodução no ambiente acadêmico-científico.

Concebemos o discurso como ambiente de interações sociais e históricas onde os sujeitos se manifestam e se inter-relacionam, modificando e sendo modificados de maneira contínua e dinâmica por meio das ideologias emergentes, constituindo uma hegemonia cultural escrita. Entendemos que, mesmo diante das peculiaridades relativas ao gênero, o discurso científico é intrinsecamente subjetivo e é por meio dessa subjetividade que exerce o seu poder de persuasão. O discurso científico é, pois: persuasivo, intencional e norteado por objetivos. Neste sentido, a análise deste discurso partindo da visão tridimensional nos permitiu elaborar uma concepção sobre as marcas discursivas emergentes de artigos científicos da área contábil. Sintetizando os achados desta investigação, podemos afirmar que os resultados do corpus em análise agregado à opinião dos pesquisadores entrevistados nos permite inferir que o discurso científico contábil revelou-se inibidor de criticidade e inovação, e este fato vai ao encontro da nossa tese: as formações discursivas das publicações definitivas da área contábil no Brasil contêm ideologias que inibem a materialização de contribuições e inovações decorrentes da investigação na área. Esta interpretação se sustenta nas constatações a seguir.

A primeira delas diz respeito à construção das orações que compõem o discurso. Identificamos que os operadores argumentativos que são fundamentalmente utilizados são contrajunção, conjunção e conclusão, tanto no artigo 22.65.2 quanto no artigo 26.67.4. Todavia, ao avaliar os 245 operadores em cada ato de fala, identificamos equívocos que fragilizam a comunicação, como o uso de contrajunção em ideias que na realidade não se contrapõem, que representam uma contraposição um tanto quanto frágil por se referir a aspectos internos ao texto e, em outros casos, terem formato de concessão. Como expusemos anteriormente, não se trata de admitirmos a conveniência de não utilizar tais operadores a fim de evitar o seu mau uso, mas de utilizá-los de maneira que possam suscitar no leitor reflexões, incômodos e expectativas que são comuns a textos argumentativos.

A contraposição oportuniza posicionamento enfático/crítico com potencialidade para 
gerar adesão ou contraposição por parte dos leitores; assim, consideramos que o seu emprego é muito bem-vindo em textos científicos. Apesar de fundamentados em relações argumentativas que favorecem a construção de um pensamento crítico - contrajunção, conclusão e conjunção - a análise dos atos de fala nos revela que o discurso científico contábil dos artigos 25.66 .2 e 26.67.4 usa a contrajunção de maneira inapropriada e/ou rasa. Este fato traz substancial prejuízo reflexivo, uma vez que os operadores que introduzem controvérsia, geralmente, atraem o leitor e provocam expectativas acerca do embate que se espera constatar. Quando não há embate, minimiza-se a possibilidade de interação ativa com o consumidor do texto, tornam-se improváveis os questionamentos e a possibilidade de construir ou reconstruir concepções críticas diante da temática. Somos de opinião que o texto científico é capaz de provocar incômodos e modificar a realidade na qual está inserido. Ao usar as contrajunções de maneira equivocada, o discurso assume passividade aproximando-se das construções frásticas de um texto literário.

No que diz respeito aos argumentos de conclusão, também predominantes nos textos, temos que a maioria deles se fundamenta numa conclusão que parte de um intertexto manifesto (outras vozes do discurso). Em outras palavras, o autor se utiliza de uma informação que possui autoridade científica (citação direta ou indireta) para estabelecer a sua conclusão, ou estabelece uma assertiva que tem como fechamento/conclusão a voz de outros autores. A intertextualidade manifesta, que se assenta sobre a prática discursiva da ciência na área contábil, é sobressalente; e como os textos analisados se vinculam a uma revista de visibilidade na área contábil (RC\&F), tal fato acaba promovendo replicações ideológicas e a hegemonia de um discurso que pouco ou nada contribui para a cultura científica na área.

Já no caso dos operadores de conjunção, temos que eles interligam atos de fala que buscam, na maioria dos casos, uma assertiva vinculada a outros autores em outras pesquisas. A nosso ver esta atitude traz à tona uma insegurança ou excesso de zelo na busca pela comprovação/conformidade para sustentar as falas e ao mesmo tempo garantir o silenciamento - como se a garantia do silenciamento e a pactuação com o óbvio, a exemplo de resultados de pesquisas anteriores, fossem uma maneira de garantir que seu discurso seja publicado e que o "protocolo" que dá o caráter de cientificidade aos textos seja cumprido de forma exímia.

No caso dos argumentos de exemplificação, comparação, comprovação e generalização, também estes estão constantemente vinculados a vozes de outros autores e, portanto, não permitem a evidenciação das contribuições que decorrem dos achados das pesquisas - fato bastante preocupante. As ideias dos autores remetem a questões normativas e 
a metodologias vinculadas a conhecimentos matemático-estatísticos. Há apropriação de uma literatura internacional de países desenvolvidos como Reino Unido, Estados Unidos e Holanda, e uma concentração das ideias dentro de áreas de conhecimento muito próximas à Contabilidade como Administração e Economia. Percebe-se "timidez"/"respeito" no discurso que o impedem de extravasar os dados e estabelecer concepções com o contexto social e econômico aos quais se vinculam - as orações construídas acabam por se constituir em relatos e descrições.

Dada à representação e visibilidade da RC\&F no Brasil e em outros países, a forma de fazer ciência disseminada neste periódico acaba por tornar-se "modelo" e referência. Este fato torna-se preocupante quando vinculado à necessidade que alguns pesquisadores têm de disseminar suas "pesquisas oportunistas", seja por coerção institucional, seja pelo desejo descomprometido de poder e prestígio. Inquieta-nos saber que há um cenário de acomodação de pesquisadores que negligenciam o seu entorno e sua própria literatura objetivando, fundamentalmente, produtividade científica. Geralmente, esses pesquisadores que produzem "pesquisas oportunistas" não têm interesse/energia para desbravar caminhos e construir ciência de interesse global, ou seja, temáticas relevantes mundialmente e que ao mesmo tempo sejam capazes de trazer resultados/benefícios locais efetivamente. A frenética "necessidade" de produção científica tem levado alguns "pesquisadores" a tentar manter-se junto a centros de pesquisa hegemônicos, ou seja, de um grupo de intelectuais que possuem prestígio acadêmico para, por conseguinte, se tornarem capazes de delimitar seus espaços no âmbito acadêmico e em entidades/instituições vinculadas à área. Todavia tal comportamento favorece ao estabelecimento de um pseudo pesquisador já que, geralmente, ocupa papel coadjuvante em sua própria história científica, não inovam ou materializam significativa contribuir a cultura escrita da sua área de conhecimento.

No que diz respeito ao léxico, observamos que as palavras de polaridade positiva são significativamente mais comuns do que as de polaridade negativa; além disso, há um contínuo uso de palavras estrangeiras como se fossem da língua portuguesa, os estrangeirismos. Outro fator bastante forte é a prevalência do jargão técnico contábil e de áreas afins, bem como de expressões decorrentes de áreas como direito, matemática e estatística, sendo que estas duas últimas também são percebidas por meio da forma como os autores exibem as imagens no texto, ou seja, os resultados são expressos por meio de fórmulas, gráficos e tabelas - a prevalência desses aspectos representa hegemonia que delimita identidade ao discurso científico contábil. Mesmo quando o discurso revela a natureza social da contabilidade, como ocorreu no artigo 26.67.4, não se percebe na discussão dos resultados qualquer menção a 
aspectos sociais ligados à área.

Tal situação é ratificada nas entrevistas por meio da opinião de pesquisadores que compõem o corpo editorial de periódicos científicos que publicam, exclusivamente, produção científica da área contábil. Os PEs consideraram o discurso contábil como neutro, desestruturado logicamente, enviesado, descritivo, superficial, imaturo, descontextualizado, moldado, intuitivo e descomprometido - identificamos ênfase ligada a termos de polaridade semântica negativa. As características enfatizadas pelos pesquisadores vão ao encontro dos achados decorrentes da apreciação do discurso, principalmente, no que diz respeito à fragilidade das argumentações e aos aspectos relacionados ao engessamento do léxico, apesar de considerarmos que algumas destas características extravasam a descrição dos atos de fala enunciados nos artigos que examinamos.

Soma-se a estas constatações o fato de que temos um contexto (RC\&F) que reflete as características específicas de uma concepção de mundo vinculada aos intelectuais que constituem a sua equipe editorial - formação no exterior, principalmente EUA, e vinculados a órgãos técnicos e/ou de representação da classe contábil nacional e internacionalmente. Não estamos fazendo um julgamento das regras editoriais ou da equipe editorial do periódico, ou questionando a competência profissional e a qualidade das produções científicas decorrentes deste grande centro; o que dizemos é que ele representa uma realidade específica do país e parte da sua ideologia origina-se de países que possuem realidade social, cultural e econômica divergentes da brasileira, bem como a organismos vinculados à atividade técnico-normativa e/ou de pesquisa.

Como afirma van Dijk (2008), a pesquisa é uma das maneiras de firmar a concepção de vida de um grupo de indivíduos; e Morin (2005), a complexidade da ciência decorre de a mesma se vincular inseparavelmente do social e histórico. A RC\&F é vinculada ao departamento da USP, e seu conselho editorial é constituído, majoritariamente, por pesquisadores que têm ou já tiveram vínculos com esta instituição - este fato se justifica porque a USP é pioneira na formação de doutores e destaca-se nacionalmente pelo trabalho que vem desenvolvendo em matéria de pesquisa no país.

Neste processo, identificamos que a produção científica publicada sofre forte influência ideológica da USP e dos Estados Unidos; da USP, não só por ser vinculada ao Departamento de Contabilidade, mas principalmente porque significativa parcela de seus avaliadores possui ou possuía vínculo com a Universidade de São Paulo - são egressos do mestrado/doutorado do programa de Controladoria e Contabilidade ou docentes dessa instituição. Assim, a forma de conceber ciência e de construir os textos científicos está 
imbricada de aspectos formativos endógenos.

Identificamos também que a base teórica dos artigos publicados é fundamentada em artigos de língua inglesa, prioritariamente. Não detectamos a utilização de trabalhos que se fundamentem em teoria. Percebemos que há um discurso hegemônico construído por uma forte marca de intertextualidade manifesta, ou seja, há tímida ou nula interferência do autor sobre as discussões, não se percebe posicionamento crítico mais contundente.

Estes aspectos delimitam/apontam aspectos problemáticos que precisam ser tomados como prioridade não só no momento da concepção de um projeto de pesquisa, mas principalmente no processo de formação do pesquisador a fim de que as replicações vazias de contribuição não se perpetuem. É preciso incitar a capacidade reflexiva e a percepção das urgências que emergem da realidade circundante, abrindo espaço para debates profícuos e significativos - que sejamos capazes de atrair o respeito e interesse de pesquisadores a partir de uma ciência que seja fiel aos interesses e questões nacionais, dado que isto não significa estar desconectado com questões relevantes da ordem mundial.

Sem perder de vista as limitações do pesquisador; a subjetividade da interpretação que estabelecemos; a necessidade limitação do corpus em estudo dada a priorização da profundidade na análise do mesmo; concebemos que esta investigação tem como contribuições: a evidencia de fragilidades relacionadas à argumentação de trabalhos científicos na área contábil - sejam essas relacionadas à tessitura do texto ou a forma tímida/passiva de expormos nossa opinião sobre o cenário em estudado - além disso, propicia uma discussão sobre um dos periódicos contábil de expressão no Brasil, trazendo ponderações sobre a influência dos conselheiros, e dos organismos que os mesmos representam, na ideologia dominante em um periódico - ideologia que emerge do seu escopo e se refletem nas publicações que o mesmo veicula. Tais ideologias representam concepções que se pretende disseminar. Ademais, reflexões sobre: a necessidade de adoção de uma teoria de base para sustentar às questões que se busca debater; as contraposições de ideias de estudiosos nos textos científicos que elaboramos; bem como sobre a realização de pesquisas que tenham foco no discurso do conhecimento contábil são significativas e potenciais provocações deste estudo. Vale salientar que a análise de corpus vinculado a outros periódicos e de artigos vinculados a outras linhas de pesquisa, podem ser um caminho frutífero para obtenção informações sobre a hegemonia do discurso vivenciado na área e sobre apatia/inércia de parte dos pequenos centros em matéria de produção científica. 



\section{REFERÊNCIAS}

Adinolfi, V. T. S. (2006). Discurso científico, poder e verdade. Revista Aulas. Dossiê Foucault, 1-10.

Alves, A. R. (2010a). Apropriações da noção de hegemonia de Gramsci na teoria social contemporânea. Seminário Gramsci e os movimentos populares, 1-10.

Alves, A. R. (2010b). O conceito de hegemonia: de Gramsci a Laclau e Mouffe. Lua Nova, 71-96.

André, A. P., Henriques, M. J. R., \& Alves, P. (2005). Reflexões sobre pesquisa científica e ideologia em ciências sociais. Seminário Nacional Estado e Politicas Sociais no Brasil.

Aragão, I. R. B. N., Martins, G. de A., \& Casa Nova, S. P. de C. (2012). Pesquisa científica em Contabilidade: caminhos a percorrer. In Congresso USP de Controladoria e Contabilidade (pp. 1-14). São Paulo: FIPECAFE/FEA/USP.

Associação Nacional de Pós-graduação e Pesquisa em Administração. (2010). Boas práticas da publicação Científica: um manual para autores, revisores, editores e integrantes de Corpos Editoriais. Retrieved from www.anpad.org.br/diversos/boas_praticas.pdf

Austin, J. L. (1998). Como hacer cosas con palabras. Barcelona: Paidós.

Barzotto, V. H. (no prelo). Leitura, escrita e relação com o conhecimento. Campinas: Mercado de Letras.

Barzotto, V. H. (2011). Instâncias formadoras, domínio da escrita e poder do professor. In Cruz, M \& Batista, I. M. (orgs). Linguagem e $(m)$ interação: línguas, literaturas e educação. São Paulo: Editora Unemat.

Bakhtin, M. (2003). Estética da criação verbal. São Paulo: Martins Fontes.

Bakhtin, M. (2006). Marxismo e Filosofia da Linguagem. São Paulo: Ed. Hucitec.

Barros, D. E. C. (2012). Argumentação e linguagem: da retórica à concepção de discurso como prática social. Revista Desenredo, 8(2).

Barros, D. E. C.(2008). Análise do discurso crítica: pesquisa social e linguística. Anais eletrônico da la JIED-Jornada Internacional de Estudos do Discurso, 27, 28.

Bauman, Z. (2005). Identidade: entrevista a Benedetto Vecchi. Rio de Janeiro: Zahar.

Bobbio, N., \& Coutinho, C. N. (1982). O conceito de sociedade civil. Rio de Janeiro: Graal.

Boje, D. M., Oswick, C., \& Ford., J. D. (2004). Language and organization: The doing of discourse. Academy of Management Review, 571-577.

Brandão, H. H. N. (2004). Introdução à análise do discurso. Campinas, Editora Unicamp.

Butler, J. (1999). Corpos que pesam: sobre os limites discursivos do "sexo". O corpo educado: pedagogias da sexualidade. Belo Horizonte: Autêntica.

Butler, J. P. (2000). Contingency, Hegemony, Universality: Contemporary Dialogues on the Laft. Verso. 
Camargo Júnior, K. R. (2013). Produção científica: avaliação da qualidade ou ficção contábil? Cad. Saúde Pública, 29(9), 1707-1730.

Campos, J. F. D. S. (2012). A natureza ideológica e política do conhecimento geográfico: o papel da pesquisa e dos conceitos na questão agrária espanhola e brasileira. GeoGraphos. Revista Digital para Estudiantes de Geografía y Ciencias Sociales, 1-9.

Cardoso, A. (2006). Linguagem, discurso e ideologia. Linguagens e diálogos, 122-127.

Retrieved from http://linguagensedialogos.com.br/2010.1/textos/09ensAnaCarolina.pdf.

Cardoso, R. L., Pereira, C. A., \& Guerreiro, R. (2004). A produção acadêmica em custos no âmbito do EnANPAD: uma análise de 1998 a 2003. Anais do Encontro Nacional dos Programas de Pós-Graduação em Administração, Curitiba, PR, 28.

Carrieri, A. de P. (2001). O Fim do "Mundo Telemig": a transformação das significações culturais em uma empresa de telecomunicações. Unpublished doctoral dissertation, Universidade Federal de Minas Gerais, 326f.

Carrieri, A. de P., Saraiva, L. A., \& Souza-Ricardo, P. A. G. de (Org.). (2009). Análise do discurso em estudos organizacionais. Curitiba: Juruá.

Castells, M. (1999). A era da informação: economia, sociedade e cultura. $O$ poder da identidade. São Paulo: Paz e Terra, 2, 24.

Chauí, M. D. S. (2001). O que é ideologia. São Paulo: Brasiliense.

Chia, R. (2000). Discourse analysis as organizational analysis. ORGANIZATION-LONDON, 513-518.

Chnaiderman, M. (2001). Língua(s) - Linguagem(ns) - Identidade(s) - Movimento(s): uma abordagem psicanalítica. In: Signorini, I. (ORG). Língua(gem) e Identidade: elementos para uma discussão no campo aplicado. Campinas: FAPESP.

Coracini, M. J. R. F. (1991). Um fazer persuasivo: o discurso subjetivo da ciência. EDUCEditora da PUC-SP.

Cordeiro, J. F. P. (2008). A produção em história da educação no Brasil Em três periódicos: perspectivas comparadas. Disponível em: http://www.sbhe.org.br/novo/congressos/cbhe_2008/pdf/698.pdf.

Courtine, Jean-Jacques. (2009). Análise do discurso político: o discurso comunista endereçado aos Cristãos. São Carlos: Edfscar.

Coutinho, C. (1999). Gramsci: um estudo sobre o seu pensamento político. Rio de Janeiro: Civilização Brasileira.

Demo, P. (1995). Metodologia científica em ciências sociais. 3. ed.. São Paulo: Atlas.

Dubois, J. (2007). Dicionário de lingüística. Editora Cultrix.

Eagleton, T. (1997). Ideologia. Unesp.

Fairclough, N. (1989). Language and power. London: Longman.

Fairclough, N. (1995). Critical discourse analysis: papers in the critical study of language. New York: Longman. 
Fairclough, N. (2003). Analysing discourse: textual analysis for social research. New York: Routledge.

Fairclough, N. (2008). Discurso e mudança social. Brasília: UNB.

Ferreira, F. A. (2011). Para entender a Teoria do Discurso de Ernesto Laclau. Revista Espaço Acadêmico, 12-18.

Ferreira, O. S. (1986). Os 45 cavaleiros húngaros: uma leitura dos Cadernos de Gramsci. São Paulo-Brasília: Hucitec e Ed. UnB.

Frezatti, F., Nascimento, A. R. do, \& Junqueira, E. (2009). Desenvolvimento da pesquisa em Contabilidade Gerencial: as restrições da abordagem monoparadigmática de Zimmerman Management accounting research development : the restrictions of

Freitas, L. K. M. R. Heterogeneidade e polifonia d (n) o discurso acadêmico: as vozes que habitam o dizer científico. Revista linguagem. 1(16).

Fiorin, J. L. (1993). Linguagem e ideologia. Editora Ática.

Foucault, M. (1996). A arqueologia do saber. Rio de Janeiro: Forense Universitária.

Franco, M. L. P. B. (2004). Representações sociais, ideologia e desenvolvimento da consciência. Cadernos de Pesquisa, 34(121), 169-186.

Futuyma, D. J. (2002) Evolução, ciência e sociedade. J. S. Morgante (Ed.). Sociedade Brasileira de Genética.

Goergen, P. (1998). Ciência, sociedade e universidade. Educação \& Sociedade: educação social, 1-13.

Goldman, A. I. (2002). Knowledge and social norms. Science, 2148.

Gramsci, A. (1995). Os intelectuais e a organização da cultura (9 ed.). (C. N. Coutinho, Trad.) Rio de janeiro: Civilização Brasileira.

Gramsci, A. (1999). Cadernos do cárcere: introdução ao estudo da filosofia: a filosofia de Benedetto Croce. Rio de Janeiro: Civilização Brasileira.

Guilhaumou, J. J., \& Maldidier, D. (1986). Effets de l'arquive. L'analyse de discours du cote de l'histoire. Langages, Paris.

Halliday, M. (2004). An introduction to functional grammar. London: Hodder Education.

Hendges, G. (2002). Citando na internet: um estudo de gênero da Revisão da literatura em artigos acadêmicos eletrônicos. MEURER, JL; MOTTA-ROTH, D. Gêneros textuais e práticas discursivas. Bauru, SP: EDUSC.

Ivanič, R. (1998). Writing and identity: The discoursal construction of identity in academic writing (Vol. 5). John Benjamins.

Japiassu, H. (1975). O mito da neutralidade científica. Rio de Janeiro: Imago.

Koch, I. G. V. (1999). Argumentação e linguagem. Cortez Editora.

Koch, I. G. V.(2010). O texto e a construção dos sentidos. São Paulo: Contexto.

Laclau, E. (1986). Os novos movimentos sociais e a pluralidade do social. Revista Brasileira de Ciências Sociais, 41-47. 
Laclau, E., \& Mouffe, C. (1987). Hegemonía y estrategia socialista: hacia una radicalición de la democracia. Buenos Aires: Fondo de Cultura Económica de Argentina.

Le Page, Robert. (1980). Projection, focussing, diffusion. York Papers in Linguistics, 9-31.

Lupton, D. (1992). Discourse analysis: Anew methodology for understanding the ideologies Machado, M. A. V., da Silva Macedo, M. A., \& Machado, M. R. (2015). Análise da Relevância do Conteúdo Informacional da DVA no Mercado Brasileiro de Capitais. Revista Contabilidade \& Finanças, 26(67), 57-69.

Magalhães, C. (2001). Reflexões sobre a análise crítica do discurso. Belo Horizonte: UFMG.

Martins, G. A. (2008). Estudo de caso: uma reflexão sobre a aplicabilidade em pesquisas no Brasil. Revista de Contabilidade e Organizações, 2(2), 4-18.

Martins, G. A., \& Theóphilo, C. (2009). Metodologia da investigação científica para ciências sociais aplicadas. São Paulo: Atlas.

Martins, G. de A., \& Zanchet, A. (2012). Sobre a complexidade dos achados de pesquisas contábeis. Colóquio Internacional de Epistemologia e Sociologia da Ciência da Adminstração, 1-17.

Melo, I. F. (2009). Análise do discurso e análise crítica do discurso: desdobramentos e intersecções. Revista Eletrônica de Divulgação Científica em Lingua Portuguesa, Lingüistica e Literatura . 1-18.

Mendonça, D. de. (2007). A teoria da hegemonia de Ernesto Laclau e a análise política brasileira. Ciências Sociais Unisinos, 43(3), 249-258.

Minayo, M. C. S. (2002). Pesquisa Social: teoria, método e criatividade. Petropoles: Vozes.

Morin, E. (2005). Ciência com consciência. (M. D. Alexandre, \& M. A. Dória, Trads.) Rio de Janeiro: Bertrand Brasil.

Nascimento, A. R. D. (2011). Controle gerencial como prática social e organizacional: análise crítica a partir de três paradigmas de pesquisa (Doctoral dissertation, Universidade de São Paulo).

Nasio, J-D. (1997) Lições sobre os 7 conceitos cruciais da psicanálise. (Vera Ribeiro, Trad.). Rio de Janeiro: Jorge Zahar Ed. (Trabalho original publicado em 1988).

Oliveira, M. C. (2002). Análise dos periódicos brasileiros de contabilidade. Revista Contabilidade \& Finanças, 13(29), 68-86.

Orlandi, E. (1996). Interpretação: autoria, leitura e efeitos do trabalho simbólico. Petrópolis, Vozes.

Orlandi, E. (2001). A linguagem e seu funcionamento: as formas do discurso. Campinas: Pontes.

Orlandi, E. P. (2009). Análise de Discurso: princípios \& procedimentos. Campinas: Pontes.

Paiva, R. (2001). Minorias flutuantes: novos aspectos da contra-hegemonia. In Congresso brassileiro de ciencias da comunicacao-intercom (Vol. 24).

Pallú, N. M. (2013). A produção social da identidade e a pedagogia da diferença. Educere at Educere: Revista de Educação, 505-510.

Patto, M. H. (2006). Psicologia e ideologia: uma introdução crítica à psicologia escolar. Psicologia, 17(1), 11-16. 
Pêcheux, M. (1990). Análise automática do discurso. Por uma análise automática do discurso: uma introdução à obra de Michel Pêcheux. Campinas: Unicamp, 2, 61-151.

Pêcheux, M. (1995). Semântica e Discurso - uma crítica à afirmação do óbvio. Campinas: Editora da Unicamp.

Peleias, I. R., Silva, G. P. da, Segreti, J. B., \& Chirotto, A. R. (2007). Evolução Do Ensino Da Contabilidade No Brasil : Revista Contabilidade \& Finanças, spe(18), 19-32.

Portelli, H. (1977). Gramsci e o bloco histórico. Rio de Janeiro: Paz e Terra.

Reed, M. (2000). The limits of discourse analysis in organizational analysis. Organization, 524-530.

Richardson, R. J. (1999). Pesquisa Social: métodos e técnicas. São Paulo: Atlas.

Rolnik, S. (1997). Toxicômanos de identidade: subjetividade em tempo de globalização. Cultura e subjetividade: saberes nômades. Campinas: Papirus, 19-24.

Sargentini, V. \& Navarro-Barbosa, P. (Org.). (2004). Foucault e os domínios da linguagem: discurso, poder, subjetividade. São Carlos: Claraluz.

Schwartzman, S. (1981). Ciência, universidade e ideologia: a política do conhecimento. Zahar Editores.

Schwartzman, S. (2009). A pesquisa científica e o interesse público. Revista Brasileira de Inovação, 1(2), 361-395.

Silva, D. E. G. D. \& Ramalho, V. (2008). Análise de Discurso Crítica: representações sociais na mídia. Análise do Discurso hoje, 2, 265-292.

Silva, T. T. (2009). A produção social da identidade e da diferença. In: Silva, T. T. da (org.). Identidade e diferença: a perspectiva dos estudos culturais. Petrópolis: Vozes. 73102.

Tobochnik, J. (2008). The art of doing. American Journal of Physics, 76(8), p. 701.

Triviños, A. N. S. Introdução à pesquisa em ciências sociais: a pesquisa qualitativa em educação. São Paulo: Atlas, 1987.

Targino, M. D. G. (2010). Divulgação científica e discurso. Comunicação \& Inovação, 8(15).

Trzesniak, P. (2009). A Estrutura editorial de um periódico científico. In Publicar em Psicologia: um Enfoque para a Revista Científica (pp. 87-102). São Paulo: Associação Brasileira de Editores Científicos de Psicologia; Instituto de Psicologia da Universidade de São Paulo.

Van Dijk, T. A. (2008). Discurso e poder. São Paulo: Contexto.

Van Dijk, T.A. (1990). La Notícia como Discurso: compreensión, estructura y producción de la información. Barcelona: Paidós.

Wodak, R. (2010). Do que trata a ACD-um resumo de sua história, conceitos importantes e seus desenvolvimentos. Linguagem em (Dis)curso, 4, 223-243.

Zanchet, A., Marques, C., \& Martins, G. D. A. (2011). Epistemologia das Abordagens Metodológicas na Pesquisa Contábil: do Normativismo ao Positivismo. EnANPAD, 117.

http://qualis.capes.gov.br/webqualis/principal.seam. Acesso em: 20 jun. 2015.

http://www.revistas.usp.br/rcf/about/history. Acesso em: 19 jun. 2015. 



\section{APÊNDICES}

\section{Apêndice A: E-mail encaminhado à Comissão de Pesquisa da FEA/USP}

Prezados(as)

Sou estudante do curso de doutorado do Programa de Pós-Graduação em Controladoria e Contabilidade da USP, sob a orientação da Prof $^{a}$. Dr ${ }^{a}$. Silvia Pereira de Castro Casa Nova e pelo Prof. Dr. Gilberto de Andrade Martins (ambos em cópia) e estou desenvolvendo uma pesquisa de tese intitulada " DISCURSO CIENTÍFICO: ESTUDO DA HEGEMONIA NA PESQUISA CONTÁBIL BRASILEIRA " visando investigar as identidades constitutivas da prática articulatória hegemônica do discurso na pesquisa científica contábil produzida no Brasil .

O estudo baseia-se na análise de artigos científicos publicados na Revista Contabilidade e Finanças da FEA/USP, além de entrevista (semi-estruturada), realizada junto à editores de revistas que publicam artigos da área contábil. Deste modo, considerando que o Comitê de Ética da FEA ainda não está implantado, gostaria que, se possível, o nosso projeto (em anexo) fosse avaliado pela Comissão de Pesquisa, a fim de verificar se não há algum problema de cunho ético.

Me coloco a disposição para quaisquer esclarecimentos, através deste e-mail e do telefone (75) 991460317 e (11) 948351925.

Desde já agradeço pela atenção, Iracema Raimunda Brito Neves Aragão. 


\section{Apêndice B: E-mail convite para a participação na investigação}

Prezado Prof. Dr. XXXXXXXX,

$\mathrm{Eu}$ sou Iracema Neves Aragão, sou doutoranda do programa de em Controladoria e Contabilidade da FEA/USP e professora da Universidade Estadual de Feira de Santana. Estou desenvolvendo uma pesquisa para minha tese. Sou orientanda do Prof. Dr. Gilberto Martins. Como parte da pesquisa, planejamos realizar entrevistas com editores, ex-editores e membros do corpo editorial de periódicos da área de Contabilidade buscando entender suas percepções sobre a forma e função da pesquisa em contabilidade no Brasil.

A entrevista será realizada por skype, preferencialmente com áudio e vídeo, nos dias e horários de sua conveniência. Estima-se cerca de 30 minutos de entrevista, a qual será gravada e transcrita, com os trechos mais relevantes marcados. A transcrição será enviada para sua análise e edição, se necessária, juntamente com um Termo de Consentimento Livre e Esclarecido. Sua participação é voluntária sendo que pode solicitar a exclusão a qualquer momento, simplesmente comunicando.

Será garantido o anonimato dos participantes, ou seja, os trechos das falas serão codificados. Os achados serão utilizados somente com finalidades acadêmicas.

Sua colaboração é imprescindível neste processo, desde já agradeço pela disponibilidade.

Cordialmente, Iracema

Elaboramos questões introduzidas por um pequeno comentário para melhor situar:

De forma geral, quando desejamos identificar uma pessoa, atribuímos a ela características marcantes que determinam como e o quem ela é em nossa percepção. Essas características podem ser traços físicos, extrínsecos, mais evidentes, e traços inerentes a sua personalidade, ou seja, intrínsecos, que necessitam conhecimento mais íntimo.

A intimidade existente entre o editor de um periódico e a pesquisa contábil permite que o mesmo aponte características extrínsecas e intrínsecas que identifiquem essa pesquisa.

Assim, elaboramos três questões:

1 - Quais características atribuiria para a pesquisa contábil no Brasil disseminada por meio do artigo científico? Como as descreveria?

2 - Quais características atribuiria para a pesquisa contábil internacional disseminada por meio do artigo científico? Como as descreveria?

3 - Quais características atribuiria ao discurso científico contábil que compõe os artigos publicados em periódicos nacionais e internacionais (contribuição, inovação, postura crítica do autor? Como o descreveria? 


\section{Apêndice C: E-mail para validação da transcrição da entrevista}

Prezado(a) Pesquisador,

De acordo com protocolo de pesquisa encaminhando em e-mail anterior, segue como anexos a transcrição da entrevista que realizamos, para análise e, se necessária, edição, bem como o Termo de Consentimento Livre e Esclarecido (TCLE).

A fim de oferecermos maior comodidade ao entrevistado se, passados dez dias da data de envio desse e-mail, não houver qualquer manifestação contrária em relação ao material editado, consideraremos a concordância do mesmo como TCLE e a validação da transcrição. Agradecemos mais uma vez pela sua imprescindível e valiosa participação no processo de nossa pesquisa e nos colocamos, mais uma vez, à disposição para quaisquer esclarecimentos necessários.

Cordialmente,

Iracema Raimunda Brito Neves Aragão

Doutoranda em Controladoria e Contabilidade - PPGCC/FEA/USP

iaragao@usp.br / irbn31@yahoo.com.br-(75) 99146-0317

Prof. Dr. Gilberto de Andrade Martins

Professor Titular PPGCC/FEA/USP

martins@usp.br - (11) 3091-5820 


\title{
Apêndice D: Termo de consentimento livre e esclarecido
}

\author{
Prezado(a) Pesquisador (a),
}

Você está sendo convidado(a) a participar, voluntariamente, da pesquisa "Discurso hegemônico da Pesquisa Contábil no Brasil", relativa ao projeto de tese sob a responsabilidade de IRACEMA RAIMUNDA BRITO NEVES ARAGÃO, discente do Doutorado Interinstitucional do Programa de Pós-Graduação em Controladoria e Contabilidade da FEA/USP (PPGCC/FEA/USP) em parceria com a Universidade Estadual de Feira de Santana e associadas, orientada pelo Prof. Dr. Gilberto de Andrade Martins.

Nesta investigação, nós estamos buscando suas percepções sobre a forma/características e função/contribuição da pesquisa em Contabilidade no Brasil. A sua participação se dará por meio de entrevista semi-estruturada, realizada pessoalmente ou por Skype, preferencialmente com áudio e vídeo, nos dias e horários de sua conveniência. Estimase cerca de 30 minutos de entrevista, a qual será gravada e transcrita, com os trechos mais relevantes marcados.

Os dados serão interpretados com o uso da técnica de análise do discurso. Os riscos associados à sua participação neste estudo estão ligados a um possível desconforto com as perguntas e com a transcrição da entrevista não refletir exatamente seu pensamento. Para mitigá-los, a transcrição será feita por uma empresa especializada em degravação, assim você receberá eletronicamente o arquivo de texto da sua entrevista, para avaliação e revisão, se necessário. O sigilo e do conteúdo será preservado, sob a responsabilidade da pesquisadora, a fim de garantir a sua privacidade.

Após a defesa da tese os áudios da entrevista serão destruídos e, em nenhum momento, você será identificado (a) na análise no texto. Os resultados da pesquisa serão publicados na tese e em outros trabalhos acadêmicos dela decorrentes, e a sua identidade será preservada. Você não terá nenhum custo ou ganho financeiro por participar da pesquisa.

Quanto aos benefícios do estudo, espera-se que uma melhor compreensão de aspectos da pesquisa contábil possa provocar reflexões importantes para o desenvolvimento da cultura escrita e, assim, beneficiar a área.

Sua participação é voluntária e você é livre para recusar-se a participar, recusar seu consentimento ou interromper a participação a qualquer momento, sem que isto lhe traga qualquer penalidade.

Como retorno e agradecimento pela sua participação, encaminharemos o arquivo eletrônico da tese via e-mail para que você possa perceber quão importante foi o seu papel em todo esse processo.

Cordialmente,

Iracema Raimunda Brito Neves Aragão

Doutoranda em Controladoria e Contabilidade - PPGCC/FEA/USP

iaragao@usp.br / irbn31@yahoo.com.br - (75) 99146-0317

Prof. Dr. Gilberto de Andrade Martins

Professor Titular PPGCC/FEA/USP

martins@usp.br - (11) 3091-5820 


\section{Apêndice E: Parágrafos selecionados para análise no artigo 25.66.2}

\begin{tabular}{|c|c|}
\hline Referência & Conteúdo \\
\hline \multicolumn{2}{|r|}{ Tópico 1 - Introdução } \\
\hline$\S 1^{\underline{0}}$ & $\begin{array}{l}\text { Uma das mais importantes motivações para adoção dos International Financial Reporting } \\
\text { Standards - IFRS é a comparabilidade da informação contábil entre os países. Assim, busca-se } \\
\text { estabelecer umaa linguagem única para os mercados e um ambiente favorável a uma maior fluidez } \\
\text { do fluxo de capitais (Ball, 2006; Lima, 2010; Niyama, 2007). }\end{array}$ \\
\hline$\S 2^{\underline{0}}$ & $\begin{array}{l}\text { Assume-se, assim, que os conceitos e os critérios de reconhecimento, mensuração e divulgação } \\
\text { estabelecidos pelos IFRS oferecem uma qualidade informacional superior que implica na utilidade } \\
\text { da informação contábil que é produzida (Barth, Landsman, \& Lang, 2008; Leuz \& Wysock, } \\
\text { 2008). Estudos internacionais, sobretudo em países europeus, têm explorado essa temática e } \\
\text { proporcionado avanços na compreensão dos efeitos da adoção dos IFRS sobre a informação } \\
\text { contábil em si, bem como sobre os usuários dessa informação (Ashbaugh \& Pincus, 2001; Barth et } \\
\text { al., 2008; Garanina \& Kormiltseva, 2014; Kargin, 2013; Jarva \& Lantto, 2012; Landsman, } \\
\text { Maydew, \& Thornock, 2012; Soderstrom \& Sun, 2007). }\end{array}$ \\
\hline$\S 3^{0}$ & $\begin{array}{l}\text { Tendo em vista o processo de convergência recentemente vivenciado no Brasil, uma questão que } \\
\text { se mostra atual e relevante é avaliar os efeitos da adoção dos IFRS sobre informação contábil } \\
\text { divulgada por firmas brasileiras. Algumas pesquisas, sob diversas perspectivas, foram } \\
\text { desenvolvidas nesse sentido, porém os resultados obtidos ainda são divergentes (Costa, 2012; } \\
\text { Lima, 2010; Macedo, Machado, Machado, \& Mendonça, 2013; Oliveira \& Lemes, 2011; } \\
\text { Rodrigues, 2012; Santos, Lima, Freitas, \& Lima, 2011). E é nesse contexto que se insere o } \\
\text { presente estudo, cujo objetivo é avaliar, no cenário brasileiro, o efeito da adoção dos IFRS sobre a } \\
\text { relevância informacional do lucro líquido, visando, assim, contribuir com uma maior } \\
\text { compreensão do tema. }\end{array}$ \\
\hline$\S 5^{0}$ & $\begin{array}{l}\text { A investigação aqui desenvolvida contemplou a capacidade associativa e a tempestividade } \\
\text { informacional do lucro contábil. Entretanto, além desses dois aspectos, pesquisas têm sugerido } \\
\text { que o conservadorismo; a existência de poucas oportunidades para o gerenciamento de resultados; } \\
\text { e a persistência dos lucros, por exemplo, podem capturar importantes dimensões da qualidade da } \\
\text { informação contábil de uma firma (Ball, 2006; Leuz \& Wysock, 2008). Portanto, é possível que } \\
\text { tais fatores também contribuam com a relevância informacional, desse modo, adicionalmente, } \\
\text { buscou-se também avaliar os efeitos da adoção dos IFRS sobre o nível de conservadorismo } \\
\text { condicional presente no lucro contábil, por tratar-se de uma importante característica relacionada à } \\
\text { tempestividade informacional. }\end{array}$ \\
\hline$\S 8^{0}$ & $\begin{array}{l}\text { É importante frisar que o enfrentamento dessa questão não incorpora a avaliação acerca da } \\
\text { qualidade da informação produzida sob os IFRS, tampouco se tais padrões são superiores aos } \\
\text { padrões domésticos, uma vez que não traça qualquer comparação entre os critérios prescritos por } \\
\text { esses conjuntos normativos, bem como não discute aspectos acerca de como essa informação } \\
\text { deveria ser, mas sim, busca avaliar o quão útil ela é (ou aparenta ser) sob a perspectiva dos } \\
\text { participantes do mercado acionário brasileiro. }\end{array}$ \\
\hline$\S 9^{0}$ & $\begin{array}{l}\text { Este artigo está dividido em } 5 \text { seções, incluindo esta introdução. Na seção 2, referencial teórico, } \\
\text { são apresentados alguns aspectos da adoção do processo de convergência no Brasil, bem como são } \\
\text { tratados alguns estudos anteriores. Na sequência, a seção } 3 \text { evidencia os aspectos metodológicos } \\
\text { empregados, tais como hipóteses, modelos etc. Na seção 4, apresentam-se e discutem-se os } \\
\text { resultados obtidos e a seção } 5 \text { conclui. }\end{array}$ \\
\hline \multicolumn{2}{|r|}{ Referencial Teórico - Tópico 2.1} \\
\hline$\S 1^{\underline{o}}$ & $\begin{array}{l}\text { Tem-se assumido que os IFRS possuem uma qualidade superior, se comparados à maioria das } \\
\text { normas ou padrões contábeis domésticos, e as pesquisas têm evidenciado resultados nessa direção } \\
\text { (Ashbaugh \& Pincus, 2001; Barth et al., 2008; Costa, 2012; Landsman et al., 2012; Lima, 2010). }\end{array}$ \\
\hline$\S 2^{\underline{0}}$ & $\begin{array}{l}\text { Se comparados aos padrões domésticos de ambientes com forte influência legal, política e tributária, } \\
\text { os IFRS: (i) refletem melhor a substância econômica dos eventos; (ii) são mais tempestivas; (iii) } \\
\text { geram lucros mais informativos; (iv) fornecem balanços patrimoniais mais úteis; e (v) reduzem a } \\
\text { manipulação de informações contábeis (Ball, 2006). }\end{array}$ \\
\hline$\S 3^{0}$ & $\begin{array}{l}\text { Contudo, essa qualidade, por si só, não garante que a adoção dos IFRS aumente a relevância da } \\
\text { informação contábil. De acordo com Soderstrom e Sun (2007), Niyama (2007), Leuz e Wysock } \\
\text { (2008) e Lima (2010), inúmeros estudos apontam que a contabilidade é o produto de fatores legais, } \\
\text { econômicos, políticos e institucionais que afetam os incentivos de divulgação financeira das firmas } \\
\text { em cada país, fatores que também exercem influência sobre o modo como os IFRS são } \\
\text { implementados e assimilados em cada país, o que gera consequências econômicas também distintas. }\end{array}$ \\
\hline
\end{tabular}




\begin{tabular}{|c|c|}
\hline Referência & Conteúdo \\
\hline$\S 4^{-}$ & $\begin{array}{l}\text { O Brasil é um país que conta com um sistema jurídico codificado e extremamente legalista (code } \\
\text { law). Antes da convergência, as normas contábeis sofriam forte influência dos ditames legais, em } \\
\text { especial da legislação tributária, e da regulamentação proveniente de organismos governamentais, } \\
\text { tais como o Banco Central do Brasil (BC) e a Comissão de Valores Mobiliários (CVM) (Dantas, } \\
\text { Rodrigues, Niyama, \& Mendes, 2010; Niyama, 2007). }\end{array}$ \\
\hline$\S 5^{-0}$ & $\begin{array}{l}\text { De acordo com Niyama (2007), os órgãos de classe contábil ou institutos representativos da } \\
\text { profissão possuíam fraca influência política no processo de determinação dos procedimentos } \\
\text { contábeis. Nesse cenário, tendo como principal usuário o governo, a informação contábil pautava-se } \\
\text { pela objetividade e verificabilidade, possuindo, assim, baixa relevância para os demais usuários, } \\
\text { sobretudo para os participantes do mercado acionário. }\end{array}$ \\
\hline$\S 6^{-}$ & $\begin{array}{l}\text { O processo de convergência às normas internacionais de contabilidade no Brasil teve como marco } \\
\text { principal a promulgação da Lei n. } 11.638 / 2007 \text {, que promoveu alterações nas leis n. } 6.404 / 1976 \text { (Lei } \\
\text { das S.A.) e n. 6.385/1976, com a finalidade de efetivar, no sistema jurídico nacional, essa } \\
\text { convergência normativa. Processo este que, conforme destacam Dantas, Rodrigues, Niyama, e } \\
\text { Mendes. (2010), desenvolvia-se desde a década de 1990, como, por exemplo, os esforços } \\
\text { institucionais da CVM no sentido de aprimorar as normas contábeis brasileiras com a incorporação } \\
\text { de preceitos do padrão do IASB. }\end{array}$ \\
\hline$\S 7^{0}$ & $\begin{array}{l}\text { No caso das firmas de capital aberto, é possível considerar que a adoção dos IFRS se deu em duas } \\
\text { etapas, uma vez que tal adoção somente passou a ser obrigatória a partir de } 2010 \text {, conforme a } \\
\text { Instrução CVM n. } 457 / 2007 \text {, alterada pela Instrução CVM n. 485/2010. Tem-se, portanto, um } \\
\text { período de transição que compreendeu os anos de } 2008 \text { e } 2009 \text {. }\end{array}$ \\
\hline$\S 10^{\circ}$ & $\begin{array}{l}\text { Sendo assim, dadas as características institucionais brasileiras antes e depois da convergência, é de se } \\
\text { esperar que a adoção obrigatória e legalmente reconhecida dos IFRS permita, no mínimo, uma maior } \\
\text { independência para a divulgação financeira, de maneira que, se os IFRS, de fato, são superiores às } \\
\text { normas domésticas, será possível observar uma maior relevância da informação contábil para os } \\
\text { participantes do mercado. }\end{array}$ \\
\hline \multicolumn{2}{|c|}{ Referencial Teórico - Tópico 2.2} \\
\hline$\S 1^{0}$ & $\begin{array}{l}\text { De uma maneira geral, os estudos têm apontado na direção de que a adoção dos IFRS aprimora a } \\
\text { qualidade da informação contábil (Soderstrom \& Sun, 2007). Contudo, no que se refere à relevância } \\
\text { informacional do lucro contábil, tal qual aqui investigada, observam-se resultados divergentes, } \\
\text { sobretudo em relação ao value relevance, um dos atributos mais pesquisados pela maioria dos } \\
\text { estudos. }\end{array}$ \\
\hline$\S 2^{\underline{o}}$ & $\begin{array}{l}\text { r exemplo, Barth, Landsman, e Lang (2008), investigando } 21 \text { países, verificaram que as firmas que } \\
\text { otaram os IFRS apresentaram maior tempestividade no reconhecimento das perdas e maior } \\
\text { sociação entre o preço das ações e o lucro contábil e o patrimônio líquido (value relevance). }\end{array}$ \\
\hline$\S 3^{\circ}$ & $\begin{array}{l}\text { (2009) indicam que a adoção } \\
\text { o lucro contábil e do patrimônio } \\
\text { s }\end{array}$ \\
\hline$\S 5^{\circ}$ & $\begin{array}{l}\text { Landsman, Maydew, e Thornock (2012) verificaram que o conteúdo informacional do lucro contábil } \\
\text { aumentou em países que adotaram os IFRS, em comparação a países que mantiveram os padrões } \\
\text { contábeis domésticos. Resultado obtido tanto em nível de países quanto em nível de firmas. Esse } \\
\text { estudo contemplou o período de } 2002 \text { a } 2007 \text { e analisou } 16 \text { países que adotaram os IFRS e } 11 \text { que } \\
\text { não adotaram, dentre estes figurou o Brasil. }\end{array}$ \\
\hline$\S 6^{-}$ & $\begin{array}{l}\text { Também em um nível multijurisdicional, Ahmed, Chalmers, e Khlif (2013) constataram, de uma } \\
\text { maneira generalizada, um aumento na associação (value relevance) entre o lucro contábil e o preço } \\
\text { das ações, porém verificaram que o nível de associação apresentado pelo patrimônio líquido não } \\
\text { sofreu alterações no período pós-IFRS. Resultados que se mantiveram mesmo após o controle dos } \\
\text { efeitos dos fatores institucionais dos países analisados }\end{array}$ \\
\hline$\S 7^{0}$ & $\begin{array}{l}\text { Por outro lado, resultados divergentes são apontados por Callao, Jarne, e Laínez (2007), cujas } \\
\text { evidências indicam que a adoção dos IFRS na Espanha não aprimorou a relevância dos relatórios } \\
\text { financeiros para os participantes do mercado acionário local. Nesse estudo, constatou-se que a } \\
\text { diferença entre o valor contábil e o valor de mercado das firmas espanholas se tornou maior com a } \\
\text { adoção dos IFRS. }\end{array}$ \\
\hline$\S 8^{0}$ & $\begin{array}{l}\text { Do mesmo modo, na Alemanha, Hung e Subramanyam (2007) constataram que os ativos totais e o } \\
\text { patrimônio líquido, bem como as variações deste e do lucro líquido, são maiores sob os IFRS e que o } \\
\text { patrimônio líquido, frente ao lucro líquido, exerce uma função mais importante na avaliação das } \\
\text { firmas e possui maior associação com o preço das ações. A constatação principal desse estudo foi a } \\
\text { alteração provocada pelos IFRS na dinâmica da informação contábil para uma parcela dos usuários. }\end{array}$ \\
\hline
\end{tabular}




\begin{tabular}{|c|c|}
\hline Referência & Conteúdo \\
\hline$\S 9^{\underline{0}}$ & $\begin{array}{l}\text { Nessa linha, Clarkson, Hanna, Richardson, e Thompson (2011) reuniram evidências que indicam } \\
\text { que a adoção dos IFRS também não aprimorou a qualidade da divulgação financeira na Europa e na } \\
\text { Austrália. A avaliação realizada nesse estudo pautou-se na verificação da associação entre o preço } \\
\text { das ações e o lucro contábil e o patrimônio líquido, sob a perspectiva tanto dos IFRS ante as normas } \\
\text { domésticas quanto do sistema jurídico dos países analisados (codificado ou consuetudinário }\end{array}$ \\
\hline$\S 10^{\circ}$ & $\begin{array}{l}\text { Já Klimczak (2011) não encontrou evidências de que a adoção obrigatória dos IFRS na Polônia teria } \\
\text { afetado o conteúdo informacional, tampouco o value relevance do lucro contábil das firmas } \\
\text { polonesas. }\end{array}$ \\
\hline$\S 11^{\circ}$ & $\begin{array}{l}\text { Jarva e Lantto (2012), por sua vez, analisando os IFRS vis-à-vis as normas contábeis finlandesas, } \\
\text { constataram que os lucros apurados de acordo com os IFRS são menos tempestivos, muito embora, } \\
\text { marginalmente, forneçam maior capacidade preditiva de fluxos de caixa futuros. Além disso, } \\
\text { verificaram que os ativos e passivos sob esses padrões apresentam menor associação com o preço } \\
\text { das ações. Umas das razões apontadas para esses resultados seria o fato de que a Finlândia já } \\
\text { dispunha de normas contábeis de alta qualidade. }\end{array}$ \\
\hline$\S 12^{-}$ & $\begin{array}{l}\text { Já Kargin (2013), analisando os efeitos da adoção dos IFRS na Turquia, encontrou evidências que } \\
\text { indicam que a adoção desses padrões não aprimorou o nível de associação entre o lucro contábil e o } \\
\text { preço das ações, por outro lado, os resultados mostraram que o patrimônio líquido apresentou maior } \\
\text { relevância no período pós-IFRS. Para Kargin (2013), esse resultado poderia ser atribuído ao fato de } \\
\text { que a aplicação dos IFRS tende a aproximar o valor do patrimônio líquido das firmas turcas ao seu } \\
\text { valor de mercado. }\end{array}$ \\
\hline$\S 14^{\circ}$ & $\begin{array}{l}\text { Já em relação ao Brasil, o cenário de pesquisa não é diferente do que se vê em nível internacional. } \\
\text { Os estudos desenvolvidos até aqui também apresentam resultados contrários, sob os mais diversos } \\
\text { aspectos relacionados aos atributos da informação contábil. }\end{array}$ \\
\hline$\S 15^{\circ}$ & $\begin{array}{l}\text { Lima (2010) explorou os efeitos da adoção dos IFRS, anos } 2008 \text { e } 2009 \text {, sobre o conteúdo } \\
\text { informacional e a relevância do lucro contábil. Não foram encontradas evidências de reações } \\
\text { anormais do preço das ações em resposta a divulgação dos lucros contábeis pós IFRS, no entanto os } \\
\text { resultados sugerem que a adoção desses padrões teria aprimorado a relevância informacional do } \\
\text { lucro contábil. }\end{array}$ \\
\hline$\S 17^{0}$ & $\begin{array}{l}\text { Costa (2012) encontrou evidências de que, nos anos de } 2009 \text { e } 2010 \text {, houve redução da } \\
\text { conformidade financeira e fiscal e de que, após a adoção dos IFRS, os coeficientes de resposta do } \\
\text { lucro contábil se mostraram significativos, o que, segundo ela, sugere um aumento na } \\
\text { tempestividade dessa medida. Contudo, contrariamente a essa conclusão, o que se observa é a } \\
\text { evidência de associação entre o lucro contábil pós-convergência e o retorno das ações (value } \\
\text { relevance), tal qual observada por Lima (2010). }\end{array}$ \\
\hline$\S 18^{\circ}$ & $\begin{array}{l}\text { Rodrigues (2012), por sua vez, dentre as suas constatações, verificou que a adoção dos IFRS no } \\
\text { Brasil não teria aumentado o conservadorismo condicional, corroborando parcialmente Santos et al. } \\
\text { (2011), tampouco afetado a capacidade associativa do lucro contábil (value relevance), neste } \\
\text { aspecto, contrariando os resultados de Lima (2010) e Costa (2012). }\end{array}$ \\
\hline$\S 19^{\circ}$ & $\begin{array}{l}\text { Contrapondo-se à Rodrigues (2012), Macedo, Machado, Machado, e Mendonça (2013) constataram } \\
\text { que a adoção dos IFRS aumentou a capacidade associativa (capacidade informacional) do lucro } \\
\text { líquido, proporcionando-lhe um maior poder explicativo. Os pesquisadores atribuem ese } \\
\text { aprimoramento ao fato de que sob os IFRS seria possível retratar com mais fidedignidade a } \\
\text { realidade econômica das firmas. Entretanto, os resultados não indicaram a existência de efeitos } \\
\text { sobre a capacidade associativa do patrimônio líquido. }\end{array}$ \\
\hline$\S 20^{\circ}$ & $\begin{array}{l}\text { É importante salientar que as divergências observadas nos estudos devem ser analisadas, em um } \\
\text { primeiro plano, à luz das diferenças legais, econômicas, políticas e institucionais existentes entre os } \\
\text { países, pois cada processo de adoção, em verdade, representa uma experiência vivenciada de } \\
\text { maneira muito particular. }\end{array}$ \\
\hline$\S 21^{\circ}$ & $\begin{array}{l}\text { Contudo, em relação ao ambiente brasileiro, à análise dos resultados, ganham importância as } \\
\text { diferenças metodológicas existentes entre os estudos, sobretudo quanto ao modelo e à técnica } \\
\text { econométrica utilizados, bem como em relação à amplitude longitudinal e transversal da amostra. }\end{array}$ \\
\hline
\end{tabular}




\begin{tabular}{|c|c|}
\hline Referência & Conteúdo \\
\hline \multicolumn{2}{|r|}{ Metodologia - Tópico 3.2} \\
\hline$\S 1^{\underline{0}}$ & $\begin{array}{l}\text { Foram objeto de estudo as firmas brasileiras de capital aberto. Somente foram consideradas aquelas } \\
\text { que se encontravam ativas em } 18 / 07 / 2013 \text {, de acordo com o critério do banco de dados } \\
\text { Economática }{ }^{\circledR} \text {. As firmas financeiras foram excluídas da amostra em razão de estarem submetidas } \\
\text { à regulação do BC. O período analisado compreendeu o } 1^{\circ} \text {. trimestre de } 1999 \text { até o } 1^{\circ} \text {. trimestre de } \\
2013 \text {, em uma base trimestral. }\end{array}$ \\
\hline \multirow[t]{3}{*}{$\S 3^{\mathrm{o}}$} & $\begin{array}{l}\text { As variáveis contábeis utilizadas foram o lucro líquido por ação (LPA) e o patrimônio líquido por } \\
\text { ação (PLA), que desempenhou a função de controle. Ambas foram obtidas nas demonstrações } \\
\text { contábeis individuais. Quando da avaliação da tempestividade informacional e do conservadorismo, } \\
\text { essas variáveis foram deflacionadas pelo preço da ação no início do período (pt-1), com o objetivo } \\
\text { de controlar uma possível heteroscedasticidade, bem como manter a similaridade com Basu (1997). } \\
\text { Além disso, foram excluídos os valores extremos para }\end{array}$ \\
\hline & $\underline{L P A_{i t}}$ \\
\hline & $\begin{array}{l}\mathrm{R} i t \text {, LPA } i t \text { (capacidade associativa) e e p p } p_{t-1} \text { (tempestividade/ conservadorismo), assim } \\
\text { considerados aqueles que se situaram nos primeiro e último percentis. }\end{array}$ \\
\hline$\S 4^{0}$ & $\begin{array}{l}\text { Desse modo, considerando os critérios de seleção empregados e a disponibilidade de dados, bem } \\
\text { como os ajustes realizados, a amostra final formou um painel desbalanceado com } 9.558 \\
\text { observações trimestrais, distribuídas entre } 246 \text { firmas. }\end{array}$ \\
\hline
\end{tabular}




\section{Apêndice F: Parágrafos selecionados para análise no artigo 26.67.4}

\begin{tabular}{|c|c|}
\hline Referência & Conteúdo \\
\hline \multicolumn{2}{|c|}{ Introdução - Tópico 1} \\
\hline$\S 1^{0}$ & $\begin{array}{l}\text { A utilidade das demonstrações financeiras depende, fundamentalmente, da relevância das } \\
\text { informações que são divulgadas aos usuários. De maneira geral, a informação contábil } \\
\text { pode ser dita relevante quando possui algumas características, tais como: (i) contribui } \\
\text { para a redução da assimetria informacional existente entre os usuários internos (gestores, } \\
\text { executivos etc.) e os usuários externos da empresa (acionistas, credores, governo etc.); } \\
\text { (ii) auxilia o usuário na avaliação dos efeitos potenciais de transações passadas, presentes } \\
\text { e futuras nos fluxos de caixa futuros (valor preditivo) e/ou confirmando ou corrigindo } \\
\text { suas avaliações anteriores (valor confirmatório); (iii) faz com que a decisão do usuário } \\
\text { seja alterada pela sua utilização, ou seja, o usuário toma uma decisão diferente da que } \\
\text { teria tomado, caso não tivesse determinada informação. }\end{array}$ \\
\hline$\S 3^{-}$ & $\begin{array}{l}\text { Esses estudos, ressaltam Brown, Lo, e Lys (1999), são normalmente conduzidos pela } \\
\text { aplicação de análises de regressão, tendo como variável dependente uma proxy } \\
\text { relacionada ao preço das ações e como variáveis independentes as informações } \\
\text { contábeis, sendo mais comum o uso de proxies relacionadas ao lucro e ao patrimônio } \\
\text { líquido. Assim, complementam Barth et al. (2001), os testes conduzidos têm foco nos } \\
\text { coeficientes das informações contábeis na equação de regressão. Em outras palavras, } \\
\text { para ser relevante, a informação contábil precisa ter seu coeficiente na equação de } \\
\text { regressão significativamente diferente de zero. }\end{array}$ \\
\hline $6^{-}$ & $\begin{array}{l}\text { Adicionalmente, a Lei 11.638/07 introduziu a obrigatoriedade da divulgação da } \\
\text { Demonstração do Valor Adicionado (DVA) para as companhias abertas, que até a } \\
\text { aprovação da referida Lei ainda não era exigida no Brasil, apesar de algumas empresas a } \\
\text { divulgarem de maneira voluntária. Destaca-se que esse demonstrativo não é contemplado } \\
\text { nas normas internacionais de contabilidade, emitidas pelo International Accounting } \\
\text { Standards Board (IASB). No entanto, vale salientar que o Global Reporting Initiative } \\
\text { (GRI) considera como indicador de desempenho o Valor Econômico Gerado e } \\
\text { Distribuído (EVG\&D), indicador muito próximo ao valor adicionado, apresentado na } \\
\text { DVA, diferindo, principalmente, pela inclusão no valor econômico distribuído dos } \\
\text { investimentos na comunidade, que incluem as contribuições voluntárias e investimentos } \\
\text { de fundos na comunidade como um todo. Tal fato demonstra a relevância do valor } \\
\text { adicionado criado e distribuído, bem como seu reconhecimento em nível internacional, } \\
\text { seja nos moldes sugeridos nas diretrizes do GRI, seja segundo as normas de } \\
\text { contabilidade vigentes. }\end{array}$ \\
\hline $7^{-0}$ & $\begin{array}{l}\text { A contabilidade não é puramente uma técnica. Reconhece-se que questões sociais podem } \\
\text { influenciar a contabilidade e que esta, por sua vez, pode mobilizar e mudar o } \\
\text { comportamento do usuário. No entanto, essas interações têm sido pouco investigadas. A } \\
\text { relação da contabilidade com o social tende a ser indicada e presumida e não descrita e } \\
\text { analisada (Burchell, Clubb, \& Hopwood, 1985). }\end{array}$ \\
\hline$\S 9^{0}$ & $\begin{array}{l}\text { É nesse contexto que se insere a DVA, foco desta pesquisa, tendo em vista ser um } \\
\text { demonstrativo que tem por finalidade demonstrar o valor adicionado gerado pela } \\
\text { entidade e como esse valor é distribuído entre todos que se esforçaram para sua criação. } \\
\text { Isso inclui não apenas os detentores de capital, mas também os funcionários, detentores } \\
\text { da força de trabalho, outros financiadores das atividades da entidade, a sociedade, por } \\
\text { meio das taxas e contribuições repassadas ao governo, e o quanto é retido na empresa. }\end{array}$ \\
\hline$\S 10^{\circ}$ & $\begin{array}{l}\text { Assim, procura-se analisar o impacto da obrigatoriedade de divulgação da DVA, por } \\
\text { meio do estudo de value relevance das informações sobre a riqueza criada. Diante do } \\
\text { exposto, questiona-se a existência de conteúdo informacional relevante da DVA para o } \\
\text { mercado de capitais brasileiro. }\end{array}$ \\
\hline
\end{tabular}




\begin{tabular}{|c|c|}
\hline Referência & Conteúdo \\
\hline$\S 11^{\underline{0}}$ & $\begin{array}{l}\text { Dessa forma, este estudo tem por objetivo analisar a relevância do conteúdo } \\
\text { informacional da DVA no mercado de capitais brasileiro. Para tanto, será analisada a } \\
\text { relação entre o preço das ações e a DVA, adotando como proxy a riqueza criada por ação } \\
\text { (RCPA), para o período de } 2005 \text { a 2011, das empresas não financeiras de capital aberto } \\
\text { listadas entre as melhores e maiores empresas, segundo a publicação anual da Revista } \\
\text { Exame em parceria com a Fundação Instituto de Pesquisas Contábeis, Atuarias e } \\
\text { Financeiras - FIPECAFI. Como objetivo secundário, este artigo procurou analisar se a } \\
\text { RCPA representava uma melhor proxy que o Lucro Líquido por Ação (LLPA), medida } \\
\text { comumente utilizada como proxy da informação contábil. }\end{array}$ \\
\hline \multicolumn{2}{|c|}{ Referencial Teórico - Tópico 2} \\
\hline$\S 1^{\underline{\underline{o}}}$ & $\begin{array}{l}\text { A contabilidade tem como objetivo mensurar e comunicar o conjunto de eventos } \\
\text { econômicos relacionados aos resultados das entidades. A informação contábil relevante } \\
\text { pode ser considerada como aquela que altera o estado da arte do conhecimento do seu } \\
\text { usuário em relação à empresa, pois, a partir de interpretações, ele a utiliza na solução de } \\
\text { problemas (Yamamoto \& Salotti, 2006). }\end{array}$ \\
\hline$\S 2^{\underline{o}}$ & $\begin{array}{l}\text { Nesse sentido, o estudo do papel da contabilidade como fornecedora de informações para } \\
\text { o mercado de capitais é de extrema importância para a avaliação da eficiência da } \\
\text { informação contábil (Iudícibus \& Lopes, 2004). A importância das informações para o } \\
\text { mercado de capitais reside não somente na questão da alocação de recursos, como } \\
\text { também no estabelecimento dos preços dos títulos, considerados os riscos e os retornos } \\
\text { (Hendriksen \& van Breda, 1999) }\end{array}$ \\
\hline$\S 3^{-}$ & $\begin{array}{l}\text { Assim sendo, esses estudos buscam verificar, utilizando o mercado financeiro como um } \\
\text { laboratório para testes, a relevância de determinada informação contábil para o mercado } \\
\text { de capitais. Em outras palavras, buscam verificar se a informação contábil é capaz de } \\
\text { auxiliar seus usuários na avaliação dos efeitos potenciais de transações passadas, } \\
\text { presentes e futuras (valor preditivo) e/ou na confirmação ou correção de suas avaliações } \\
\text { anteriores (valor confirmatório), tendo como base a hipótese dos mercados eficientes } \\
\text { (EMH) de que os preços das ações refletem toda e qualquer informação relevante e } \\
\text { disponível e ajustam-se em função desse conjunto de informações (Famá, 1970). }\end{array}$ \\
\hline$\S 4^{\underline{0}}$ & $\begin{array}{l}\text { Holthausen e Watts (2001) classificam os estudos de value relevance em três categorias, } \\
\text { podendo um mesmo estudo estar em mais de uma categoria: (i) Relative association } \\
\text { studies (Estudos de Associação Relativa), que comparam, como no caso da presente } \\
\text { pesquisa, a associação entre os valores do mercado de ações (ou alterações desses } \\
\text { valores) com formas de mensuração alternativas, tais como um padrão contábil existente } \\
\text { e um a ser proposto. Esses estudos realizam normalmente a comparação dos R2 padrão } \\
\text { contábil com maior R2 dos modelos de regressão, sendo que o é avaliado como mais } \\
\text { relevante; (ii) Incremental association studies (Estudos de Associação Incremental), que } \\
\text { investigam se o componente contábil em análise é útil para explicar valores ou retornos } \\
\text { ao longo de períodos de tempo, sendo importante incluir outras variáveis. Considera-se } \\
\text { um valor relevante se o seu coeficiente de regressão estimado é significativamente } \\
\text { diferente de zero; e (iii) Marginal information content studies (Estudos de Conteúdo } \\
\text { Informacional Marginal), que investigam se determinado valor adiciona poder } \\
\text { informacional aos investidores em relação às informações disponíveis. Tipicamente, são } \\
\text { utilizadas metodologias de estudos de evento, onde o interesse é avaliar se a } \\
\text { disponibilidade de determinada informação está associada a alterações de valor de ativos } \\
\text { (reação de preços), onde reações são consideradas evidências da relevância. }\end{array}$ \\
\hline$\S 5^{-0}$ & $\begin{array}{l}\text { Existem vários estudos que buscam verificar a relevância da informação contábil, desde } \\
\text { os primeiros estudos de Ball e Brown (1968) e Beaver (1968), que, de acordo com } \\
\text { Yamamoto e Salotti (2006), foram os precursores desse tipo de estudo. Dentre estes, } \\
\text { podem-se destacar os seguintes, de acordo com Kothari (2001) e Iudícibus e Lopes } \\
\text { (2004): Beaver, Clarke, e Wright (1979); Beaver, Lamber, e Morse (1980); Collins, } \\
\text { Maydew, e Weiss (1997); Brown et al. (1999); Lopes (2001, 2002a e 2002b). }\end{array}$ \\
\hline$\S 6^{-}$ & $\begin{array}{l}\text { Outros estudos também podem ser destacados, tais como: Foster (1977); Board e Walker } \\
\text { (1990); Strong e Walker (1993); Harris, Lang, e Moller (1994); Collins, Pincus, e Xie } \\
\text { (1999); Francis e Schipper (1999); Dhaliwal, Subramanyam, e Trezevant (1999); Sarlo } \\
\text { Neto (2004); Costa e Lopes (2007); Lopes, Sant'Anna, e Costa (2007); Galdi e Lopes } \\
\text { (2008); Bastos, Nakamura, David, e Rotta (2009); Malacrida (2009) e Zanini, Cañibano, } \\
\text { e Zani (2010). }\end{array}$ \\
\hline
\end{tabular}




\begin{tabular}{|c|c|}
\hline Referência & Conteúdo \\
\hline$\S 7^{0}$ & $\begin{array}{l}\text { Diversos autores, tais como: Brown et al. (1999); Kothari (2001); Holthausen e Watts } \\
\text { (2001) e Barth et al. (2001) deram início a discussão sobre a relação existente entre a } \\
\text { relevância da informação contábil e os padrões e normas contábeis alternativos. }\end{array}$ \\
\hline$\S 8^{\mathrm{o}}$ & $\begin{array}{l}\text { A partir desse marco teórico, alguns estudos tentaram mostrar o impacto de mudanças } \\
\text { nos padrões contábeis na relevância das informações produzidas pela contabilidade e, } \\
\text { mais recentemente, sobre o impacto do processo de convergência aos padrões contábeis } \\
\text { internacionais (IFRS). }\end{array}$ \\
\hline \multicolumn{2}{|c|}{ Metodologia - Tópico 3} \\
\hline$\S 4^{-0}$ & $\begin{array}{l}\text { As informações utilizadas na DVA são, normalmente, extraídas da Demonstração do } \\
\text { Resultado do Exercício (DRE). No entanto, não apresentam objetivos semelhantes, mas } \\
\text { complementares. A DRE tem por prioridade enfatizar o lucro líquido, que, na DVA, } \\
\text { corresponde à parcela do valor adicionado destinada aos detentores do capital. Quanto às } \\
\text { demais parcelas do valor adicionado destinadas a empregados, governo e financiadores } \\
\text { externos, na DRE, aparecem como despesas. }\end{array}$ \\
\hline$\S 5^{-}$ & $\begin{array}{l}\text { Pode-se dizer que a DRE utiliza o critério da natureza, enquanto a DVA utiliza o critério } \\
\text { do benefício. Por exemplo, na DRE, os salários de empregados envolvidos no processo } \\
\text { produtivo serão considerados como custos e os salários da administração como despesas. } \\
\text { Já na DVA, independentemente da natureza, custo ou despesa, salários pagos } \\
\text { correspondem ao valor adicionado destinado aos empregados, ou seja, é utilizado o } \\
\text { critério de benefício da renda (Iudícibus, Martins, Gelbcke, \& Santos, 2010). }\end{array}$ \\
\hline$\S 7^{0}$ & $\begin{array}{l}\text { No Brasil, até 2007, a DVA não era obrigatória. Porém, sua elaboração e divulgação } \\
\text { eram incentivadas pela Comissão de Valores Mobiliários (CVM) desde 1992. Somente } \\
\text { em dezembro de 2007, a Lei no } 11.638 / 07 \text { introduziu a obrigatoriedade da divulgação da } \\
\text { DVA para as companhias abertas. }\end{array}$ \\
\hline$\S 8^{\underline{o}}$ & $\begin{array}{l}\text { A vigente lei societária considera a DVA uma demonstração financeira semelhante às } \\
\text { demais demonstraçôs, devendo, também, ser elaborada com base nos dados extraídos da } \\
\text { escrituração contábil. Para sua elaboração, o Comitê de Pronunciamentos Contábeis } \\
\text { emitiu o pronunciamento técnico CPC } 09 \text { (2008), estabelecendo o critério de elaboração } \\
\text { e divulgação. O referido pronunciamento enfatiza que a DVA é um dos elementos } \\
\text { componentes do balanço social e que os dados para sua elaboração, em sua grande } \\
\text { maioria, são obtidos principalmente da Demonstração do Resultado. O modelo } \\
\text { apresentado pelo CPC muito se assemelha ao modelo sugerido pela Fundação Instituto } \\
\text { de Pesquisas Contábeis, Atuariais e Financeiras - FIPECAFI e utilizado por muitas } \\
\text { empresas antes mesmo da obrigatoriedade. O modelo de DVA a ser seguido, segundo o } \\
\text { CPC 09, é constituído de duas partes. A primeira destina-se a demonstrar o valor } \\
\text { adicionado total a distribuir, que contempla o valor adicionado líquido produzido pela } \\
\text { entidade acrescido do valor adicionado recebido em transferência: }\end{array}$ \\
\hline$\S 12^{0}$ & $\begin{array}{l}\text { De Luca (1998) considera que a DVA é a parte do balanço social destinada a apresentar } \\
\text { informações de natureza econômica aos vários usuários, demonstrando o desempenho } \\
\text { econômico da empresa e seu relacionamento com a sociedade. Para Santos (2007), a } \\
\text { DVA é um componente do Balanço Social e "deve ser entendida como a forma mais } \\
\text { competente criada pela Contabilidade para auxiliar na medição e demonstração da } \\
\text { capacidade de geração, bem como de distribuição da riqueza de uma entidade" (Santos, } \\
\text { 2007, p. 37). Destaca-se que tanto Santos (2007) quanto De Luca (1998), entendem que a } \\
\text { DVA é parte integrante do balanço social. }\end{array}$ \\
\hline$\S 13^{0}$ & $\begin{array}{l}\text { Para Machado (2010), a DVA tem mais notoriedade,em relação às demais vertentes do } \\
\text { balanço social, especialmente pela existência de um modelo padrão, que permite a } \\
\text { comparabilidade, a obrigatoriedade de sua publicação para as companhias abertas e a } \\
\text { utilização de dados oriundos da contabilidade para sua elaboração, o que permite maior } \\
\text { credibilidade, principalmente quando as demonstrações contábeis são auditadas. Por tais } \\
\text { motivos, é muitas vezes tratada separadamente do balanço social, de modo semelhante às } \\
\text { demais demonstrações contábeis, como, por exemplo, DRE, Balanço Patrimonial (BP) e } \\
\text { Demonstração do Fluxo de Caixa (DFC). Entende-se que, em virtude de sua relevância, a } \\
\text { DVA pode ser tratada tanto como a vertente econômica do balanço social, como a } \\
\text { vertente social das demonstrações contábeis. }\end{array}$ \\
\hline
\end{tabular}




\begin{tabular}{|c|c|}
\hline Referência & Conteúdo \\
\hline$\S 15^{\mathrm{o}}$ & $\begin{array}{l}\text { Além das vantagens da DVA apresentadas por Riahi-Belkaoui (1992), especialmente no } \\
\text { contexto brasileiro, a DVA pode ser utilizada como ferramenta para avaliar as } \\
\text { contribuições das empresas, quando da concessão de benefícios fiscais, além de ser uma } \\
\text { alternativa para o cálculo do PIB, como acrescenta Santos (2007, p. 38): “[...] parece que } \\
\text { é inquestionável seu auxílio no cálculo do PIB e de indicadores sociais extremamente } \\
\text { importantes. As decisões de investimentos por áreas, regiões, Estados etc. terão nessa } \\
\text { demonstração excelente instrumental para a solução de conflitos." }\end{array}$ \\
\hline$\S 16^{\circ}$ & $\begin{array}{l}\text { Pesquisas empíricas sobre a DVA, em nível internacional, são escassas, possivelmente } \\
\text { pelo fato dos padrões internacionais de contabilidade não contemplarem a DVA como } \\
\text { parte do conjunto de demonstrações financeiras a ser apresentada no relatório anual, } \\
\text { sendo, portanto, uma divulgação voluntária (Van Staden, 2000). Dentre os estudos } \\
\text { encontrados sobre DVA, destacam-se pesquisas que buscaram averiguar a utilização da } \\
\text { DVA (Van Staden, 1998; Stainbank, 2009) e pesquisas que tiveram foco na magnitude } \\
\text { de seu conteúdo informacional (Riahi-Belkaoui \& Fekrat, 1994; Riahi-Belkaoui \& Picur, } \\
\text { 1994; Riahi-Belkaoui \& Picur, 1999). }\end{array}$ \\
\hline$\S 17^{\circ}$ & $\begin{array}{l}\text { Riahi-Belkaoui e Fekrat (1994) analisaram a variabilidade e persistência de indicadores } \\
\text { de desempenho derivados da demonstração do valor adicionado e indicadores extraídos } \\
\text { das demonstrações financeiras. Quanto às variáveis, os autores utilizaram o valor } \\
\text { adicionado líquido, o fluxo de caixa operacional, representando métrica decorrente do } \\
\text { regime de caixa, e o lucro, representando uma medida baseada no regime de } \\
\text { competência. Assim, foram utilizados dados de } 673 \text { empresas americanas, referentes ao } \\
\text { período de 1981-1990. Os resultados apontaram que indicadores baseados no valor } \\
\text { adicionado líquido apresentam menor variabilidade e maior persistência se comparados a } \\
\text { indicadores baseados no lucro líquido ou fluxo de caixa operacional. Adicionalmente, os } \\
\text { autores destacam que as medidas contábeis de risco baseadas no valor adicionado líquido } \\
\text { têm maior associação como o mercado do que medidas baseadas no lucro ou fluxo de } \\
\text { caixa. }\end{array}$ \\
\hline$\S 18^{\circ}$ & $\begin{array}{l}\text { A utilidade do valor adicionado líquido, para explicar o retorno das ações de uma } \\
\text { amostra de empresas americanas, foi investigada por Riahi-Belkaoui e Picur (1994). O } \\
\text { estudo investigou se o valor adicionado líquido e a variação do valor adicionado líquido, } \\
\text { todos divididos pelo preço, são relevantes para explicar o retorno. Para isso, os autores } \\
\text { assumiram: (i) que o preço reflete informações que estão inclusas no valor adicionado } \\
\text { líquido anual de uma série de tempo passado; e (ii) que o preço reflete informações de } \\
\text { uma série de tempo passada da variação do valor adicionado líquido anual. O resultado } \\
\text { da pesquisa apontou que tanto o valor adicionado quanto a sua variação são relevantes } \\
\text { para explicar o retorno das ações, e que o valor adicionado líquido tem uma melhor } \\
\text { associação com o retorno do que a variação do valor adicionado líquido. }\end{array}$ \\
\hline$\S 21^{\circ}$ & $\begin{array}{l}\text { No estudo de Crippa e Coelho (2012), observa-se a mesma linha de pesquisa, porém } \\
\text { utilizando uma amostra de empresas de capital aberto no período de } 2007 \text { a } 2010 \text {, já áto } \\
\text { incluindo um período de publicação obrigatória da DVA. Os autores encontraram } \\
\text { evidências de que existe relação positiva significativa entre a riqueza gerada pelas } \\
\text { empresas da amostra com o retorno das ações, concluindo, assim, pela relevância da } \\
\text { riqueza criada para o mercado brasileiro de capitais. }\end{array}$ \\
\hline$\S 22^{\circ}$ & $\begin{array}{l}\text { Barros, Catapan, Scherer, e Isidoro (2013) deram continuidade ao estudo de Scherer } \\
\text { (2006), porém a análise foi ampliada até um período mais recente em que a publicação } \\
\text { da DVA já era obrigatória no Brasil. Porém, os resultados foram bem diferentes dos } \\
\text { achados de Scherer (2006), visto que, no estudo, não se encontrou evidência de } \\
\text { relevância do valor adicionado, com exceção para empresas listadas nos níveis } \\
\text { diferenciados de governança corporativa da BM\&FBOVESPA. }\end{array}$ \\
\hline$\S 23^{\circ}$ & $\begin{array}{l}\text { Por fim, mais recentemente, o estudo de Martins, Machado, e Callado (2014) avaliaram a } \\
\text { aditividade de value relevance da DFC e da DVA ao conjunto de demonstrações } \\
\text { contábeis no contexto do mercado acionário brasileiro. Como resultados principais, } \\
\text { apresentaram que a DVA, representada pela variável riqueza criada, não demonstrou } \\
\text { conteúdo informacional inserida isoladamente ao conjunto de demonstrações, nem em } \\
\text { conjunto com a DFC. Segundo os referidos autores, tal fato pode ser explicado pelo fato } \\
\text { de a DVA não apresentar conteúdo novo, além dos já apresentados na demonstração do } \\
\text { resultado (DRE). }\end{array}$ \\
\hline
\end{tabular}




\begin{tabular}{|c|c|}
\hline Referência & Conteúdo \\
\hline \multicolumn{2}{|c|}{ Metodologia - Tópico 4.2} \\
\hline$\S 5^{0}$ & $\begin{array}{l}\text { Sendo assim, a base de dados da Exame-FIPECAFI apresentou um total de } 1.271 \\
\text { unidades de análise, das quais } 376 \text { unidades não apresentaram informações válidas, } \\
\text { restando } 895 \text { unidades. Dessas não foram encontradas informações na base de dados da } \\
\text { Economática para } 184 \text { unidades, restando, portanto, } 711 \text { unidades válidas para análise. }\end{array}$ \\
\hline$\S 6^{-}$ & $\begin{array}{l}\text { Assim, a amostra final é composta por essas } 711 \text { observações de } 172 \text { companhias abertas } \\
\text { não financeiras, listadas na base de dados da Melhores \& Maiores, que apresentaram a } \\
\text { Demonstração do Valor Adicionado (DVA), no período de } 2005 \text { a } 2011 \text { e que tinham } \\
\text { disponíveis as outras informações necessárias. Destaca-se que cada empresa em cada ano } \\
\text { foi considerada como uma unidade de análise. Desse modo, as regressões apresentadas } \\
\text { para análise de value relevance são pooling. }\end{array}$ \\
\hline$\S 7^{0}$ & $\begin{array}{l}\text { Por fim, ressalta-se uma possível limitação da pesquisa em considerar empresas que } \\
\text { apresentaram voluntariamente a DVA no período de } 2005 \text { a } 2007 \text {. Isso pode trazer para o } \\
\text { estudo o viés de que apenas as empresas que tinham algum interesse na publicação da } \\
\text { DVA é que evidenciaram essas informações. }\end{array}$ \\
\hline \multicolumn{2}{|c|}{ Metodologia - Tópico 4.3} \\
\hline$\S 9^{-0}$ & $\begin{array}{l}\text { Tendo em vista que outros fatores, além da riqueza criada, podem influenciar o preço das } \\
\text { ações, foram incluídas, na análise empírica, algumas variáveis de controle, de modo a } \\
\text { garantir a robustez da análise. Tais variáveis são: Lucro Líquido por ação (LLPA) e } \\
\text { Patrimônio Líquido por ação (PLPA), já que essas variáveis foram encontradas em } \\
\text { grande parte dos estudos sobre value relevance, tais como Collins et al. (1997); Costa e } \\
\text { Lopes (2007); Morais e Curto (2008) e Macedo et al. (2011). }\end{array}$ \\
\hline$\S 13^{0}$ & $\begin{array}{l}\text { Para analisar se houve ganho ou perda de conteúdo ao incluir a RCPA, comparou-se o } \\
\text { R2 Assim, sendo o R2 ajustado das regressões. ajustado da Equação } 3 \text { maior que o R2 } \\
\text { ajustado da Equação 2, pode-se concluir que houve ganho informacional e, portanto, a } \\
\text { DVA possui value relavance. Adicionalmente, fez-se uso do teste de Wald. }\end{array}$ \\
\hline$\S 14^{\circ}$ & $\begin{array}{l}\text { A comparação dos modelos por meio do teste de Wald,via estatística F, é preferível à } \\
\text { comparação por meio do R2 Ajustado (Heij, de Boer, Franses, Kloek, \& van Dijk, 2004). } \\
\text { Para isso, deve-se comparar o modelo original, denominado modelo restrito (Equação 2), } \\
\text { com o modelo com as novas variáveis explicativas acrescidas, denominado de modelo } \\
\text { irrestrito (Equação 3). O objetivo é avaliar se a inclusão da variável RCPA melhora o } \\
\text { poder explicativo do modelo. Para esse teste, a estatística F é calculada conforme } \\
\text { Equação 4: }\end{array}$ \\
\hline$\S 22^{\circ}$ & $\begin{array}{l}\text { No que diz respeito ao preço das ações, considerou-se o preço da ação de maior liquidez } \\
\text { da empresa na data de } 30 \text { de abril do ano subsequente ao da publicação das } \\
\text { demonstrações contábeis. Os dados referentes à riqueza criada foram obtidos junto à base } \\
\text { de dados da FIPECAFI. Já as informações sobre preço, número de ações, Lucro Líquido } \\
\text { e Patrimônio Líquido foram extraídas do banco de dados da Economática. Uma vez que } \\
\text { os dados referentes à riqueza criada foram fornecidos em dólares americanos, as } \\
\text { informações sobre preço, Lucro Líquido e Patrimônio Líquido também foram coletadas } \\
\text { nessa mesma moeda. }\end{array}$ \\
\hline$\S 23^{\circ}$ & $\begin{array}{l}\text { Por fim, ressalta-se que toda análise de relevância da DVA está focada numa única } \\
\text { proxy: a Riqueza Criada por Ação (RCPA). Portanto, os resultados da pesquisa estão } \\
\text { sujeitos também a essa limitação. }\end{array}$ \\
\hline \multicolumn{2}{|c|}{ Resultado - Tópico 5} \\
\hline$\S 3^{\underline{0}}$ & $\begin{array}{l}\text { De acordo com a Tabela } 1 \text {, painel B, a regressão estimada, considerada isoladamente, } \\
\text { mostrou-se significativa em termos estatísticos ao nível de significância de } 1 \% \text {, tendo em } \\
\text { vista que o p-value obtido para a estatística F é inferior a } 0,01 \text {. Obteve-se um coeficiente } \\
\text { de determinação de } 0,650 \text {, evidenciando que } 65,0 \% \text { da variação no preço das ações é } \\
\text { explicada pela variação da riqueza criada. Quanto à significância, o painel A, da Tabela } \\
1 \text {, por meio da estatística t, indica que a variável RCPA mostrou-se significativa } \\
\text { estatisticamente ao nível de } 1 \% \text {, bem como o sinal previsto. Isso mostra que a RCPA é } \\
\text { uma variável que consegue explicar o preço das ações, ou seja, que a riqueza criada é } \\
\text { uma informação relevante para o mercado brasileiro de capitais. Em primeira instância, } \\
\text { esses resultados confirmam os achados de Riahi-Belkaoui e Picur (1994), Riahi-Belkaoui } \\
\text { e Picur (1999), Scherer (2006) e Crippa e Coelho (2012), porém estão parcialmente em } \\
\text { discordância com os resultados obtidos por Barros et al. (2013) e divergente do estudo de } \\
\text { Martins et al. (2014). }\end{array}$ \\
\hline
\end{tabular}




\begin{tabular}{|c|c|}
\hline Referência & Conteúdo \\
\hline$\S 4^{\mathrm{o}}$ & $\begin{array}{l}\text { A Tabela } 2 \text { demonstra os resultados da regressão, utilizando o Lucro Líquido por ação } \\
\text { (LLPA) e Patrimônio Líquido por ação (PLPA) como variáveis explicativas e o preço } \\
\text { das ações como variável dependente, conforme Equação } 2 \text {. }\end{array}$ \\
\hline$\S 5^{\circ}$ & $\begin{array}{l}\text { De acordo com a Tabela } 2 \text {, painel } \mathrm{B} \text {, a regressão estimada, considerada isoladamente, } \\
\text { mostrou-se significativa em termos estatísticos ao nível de significância de } 1 \% \text {, tendo em } \\
\text { vista que o p-value obtido para a estatística F é inferior a } 0,01 \text {. Obteve-se um coeficiente } \\
\text { de determinação de } 0,713 \text { evidenciando que } 71,3 \% \text { da variação no preço das ações é } \\
\text { explicada pela variação do LLPA e do PLPA. Quanto à significância, o painel A, da } \\
\text { Tabela } 2 \text {, por meio da estatística t, indica que tanto a variável LLPA, quanto a PLPA, } \\
\text { mostraram-se significativas estatisticamente ao nível de } 1 \% \text {, bem como apresentaram o } \\
\text { sinal previsto. Assim sendo, tem-se a confirmação da relevância das informações de } \\
\text { lucro e patrimônio líquido para o mercado brasileiro de capitais. }\end{array}$ \\
\hline$\S 6^{\circ}$ & $\begin{array}{l}\text { No intuito de verificar se os resultados obtidos na Tabela } 1 \text { eram consistentes, ou seja, se } \\
\text { a DVA possui conteúdo informacional relevante, foram incluídas variáveis de controle, } \\
\text { com objetivo de verificar se havia alteração no sinal ou na significância estatística da } \\
\text { variável RCPA }\end{array}$ \\
\hline$\S 7^{\circ}$ & $\begin{array}{l}\text { Observa-se que a inclusão das variáveis de controle LLPA e PLPA (Equação 3) não } \\
\text { alterou a significância, nem o sinal da variável RCPA (Tabela 3). Adicionalmente, } \\
\text { percebe-se uma melhora no coeficiente de determinação ajustado, em relação aos } \\
\text { resultados da Tabela 2. Percebe-se, ainda, pela análise do coeficiente de determinação } \\
\text { ajustado (Tabelas } 2 \text { e 3), um ganho informacional ao acrescentar a RCPA no modelo com } \\
\text { LLPA e PLPA (R2 Ajustado 0,712), visto que o modelo que utiliza a RCPA (Tabela 3) } \\
\text { apresentou R2 ajustado maior (0,755). }\end{array}$ \\
\hline$\S 8^{\circ}$ & $\begin{array}{l}\text { A análise de ganho ou perda informacional, com a inclusão da RCPA, de acordo com o o } \\
\text { teste de Wald, revela que o modelo da Equação } 3 \text { mostrou-se significativamente superior } \\
\text { ao modelo da Equação } 2 \text {, ao nível de } 1 \% \text { (p-valor de } 0,002 \text {, para estatística F de 9,654). } \\
\text { Logo, pode-se concluir que a inclusão da variável RCPA no modelo da Equação } 2 \\
\text { melhora o poder explicativo do referido modelo. Portanto, pode-se concluir que a } \\
\text { variável RCPA possui value relevance. }\end{array}$ \\
\hline$\S 9^{0}$ & $\begin{array}{l}\text { Com isso, percebe-se que os resultados obtidos até aqui mostram que a riqueza criada, } \\
\text { informação advinda da DVA, não só possui relevância para o mercado brasileiro de } \\
\text { capitais, como adiciona conteúdo informacional às informações de lucro e patrimônio } \\
\text { líquido. Ou seja, percebe-se que existe conteúdo informacional marginal na DVA para os } \\
\text { investidores. Esse é um achado que as pesquisas anteriores ainda não tinham observado. }\end{array}$ \\
\hline$\S 11^{\circ}$ & $\begin{array}{l}\text { De acordo com o teste de Wald, tanto o modelo da Equação } 2 \text { (p-valor de } 0,00 \text {, para } \\
\text { estatística F de } 14,30 \text { ), quanto o modelo da Equação } 6 \text { (p-valor de } 0,00 \text {, para estatística F } \\
\text { de } 17,42 \text { ), mostraram-se superiores ao modelo da Equação 5, significativo ao nível de } \\
1 \% \text {. Logo, pode-se concluir que a inclusão tanto da variável RCPA, quanto do LLPA, no } \\
\text { modelo da Equação 5, melhora o poder explicativo do referido modelo. Portanto, pode-se } \\
\text { concluir que as variáveis RCPA e LLPA possuem value relavance. }\end{array}$ \\
\hline$\S 12^{\circ}$ & $\begin{array}{l}\text { Em seguida, comparou-se os modelos representados pelas Equações } 3 \text { (Tabela 3) e } 6 \\
\text { (Tabela 4). Observa-se que, ao incluir o LLPA no modelo com PLPA e RCPA (Tabela } \\
\text { 3), praticamente, não há alteração no coeficiente de determinação ajustado. Ademais, } \\
\text { segundo o teste de Wald, o modelo representado pela Equação } 3 \text { não se mostrou superior } \\
\text { ao modelo da Equação } 6 \text { (p valor de } 0,021 \text {, para estatística F de 5,38), ao nível de } 1 \% \text { de } \\
\text { significância, resultados contrários aos obtidos quando comparado os modelos } \\
\text { representados pelas Equações } 2 \text { e } 3 \text {. }\end{array}$ \\
\hline$\S 13^{\circ}$ & $\begin{array}{l}\text { Adicionalmente, ao comparar o coeficiente de determinação ajustado e o critério de } \\
\text { informação de Schwarz dos modelos representados pelas Equações } 2 \text { (Tabela 2) e } 6 \\
\text { (Tabela 4), percebe-se um maior coeficiente de determinação ajustado para o modelo } \\
\text { com RCPA }(0,741) \text {, comparativamente ao modelo com LLPA }(0,712) \text {, bem como menor } \\
\text { valor para o critério de informação de Schwarz (7,366 e 7,471, respectivamente). Diante } \\
\text { do exposto, há indícios que o mercado reage mais à RCPA do que ao LLPA. Dessa } \\
\text { forma, os resultados obtidos podem estar revelando evidências de que, sob a ótica do } \\
\text { mercado de capitais, a RCPA poderia ser uma melhor proxy para o resultado da empresa } \\
\text { que o LLPA, o que corrobora os resultados de Riahi-Belkaoui e Picur (1999) e contraria } \\
\text { os achados de Scherer (2006). }\end{array}$ \\
\hline
\end{tabular}




\begin{tabular}{|c|c|}
\hline Referência & Conteúdo \\
\hline \multicolumn{2}{|c|}{ Considerações Finais - Tópico 6} \\
\hline$\S 1^{\underline{0}}$ & $\begin{array}{l}\text { Os estudos de value relevance objetivam verificar a relevância de determinada } \\
\text { informação contábil para o mercado de capitais. Tais estudos têm por objetivo verificar } \\
\text { se determinadas informações estão refletidas no preço das ações das empresas. Assim, } \\
\text { para a informação contábil possuir conteúdo informacional relevante, ela precisa ter seu } \\
\text { coeficiente na equação de regressão significativamente diferente de zero. }\end{array}$ \\
\hline$\S 2^{\mathrm{o}}$ & $\begin{array}{l}\text { Dentro desse contexto, este estudo teve por objetivo analisar a relevância do conteúdo } \\
\text { informacional da Demonstração do Valor Adicionado (DVA) no mercado brasileiro. Para } \\
\text { tanto, analisou-se a relação entre o preço das ações e a riqueza criada por ação (RCPA), } \\
\text { para o período de } 2005 \text { a } 2011 \text {, das empresas não financeiras de capital aberto listada } \\
\text { entre as melhores e maiores empresas, segundo a publicação anual da Revista Exame. } \\
\text { Como objetivo secundário, este artigo procurou analisar se a RCPA representava uma } \\
\text { melhor proxy para o resultado que o LLPA. }\end{array}$ \\
\hline$\S 3^{-0}$ & $\begin{array}{l}\text { As evidências empíricas encontradas sugerem que a DVA possui conteúdo informacional } \\
\text { relevante, pois consegue explicar a variação no preço das ações das empresas } \\
\text { pesquisadas. Adicionalmente, a relação entre a RCPA e o preço mostrou-se significativa, } \\
\text { mesmo depois da inclusão das variáveis de controle. }\end{array}$ \\
\hline$\S 4^{0}$ & $\begin{array}{l}\text { Observa-se que, ao incluir o LLPA no modelo com PLPA e RCPA, praticamente, não há } \\
\text { alteração no coeficiente de determinação ajustado. Ademais, a comparação entre os } \\
\text { modelos com PLPA e RCPA e com PLPA e LLPA revelou evidências de que o mercado } \\
\text { reage mais à RCPA do que ao LLPA. Dessa forma, os resultados obtidos revelam } \\
\text { indícios de que a RCPA representa uma melhor proxy para o resultado da empresa que o } \\
\text { LLPA, corroborando os resultados de Riahi-Belkaoui e Fekrat (1994), Riahi-Belkaoui e } \\
\text { Picur (1994) e Riahi-Belkaoui e Picur (1999). }\end{array}$ \\
\hline$\S 5^{-}$ & $\begin{array}{l}\text { Possivelmente, esse resultado justifica-se por ser a riqueza criada uma medida mais } \\
\text { abrangente do desempenho da empresa que o lucro líquido que representa apenas parcela } \\
\text { da riqueza criada, destinada aos detentores de capital. Assim, presume-se que o mercado } \\
\text { espera das empresas não apenas a remuneração do capital próprio, mas, principalmente, a } \\
\text { geração de riqueza que possa garantir a viabilidade futura, bem como remunerar todos os } \\
\text { que se esforçam para a geração de riqueza. Supõe-se, também, que o mercado pode estar } \\
\text { considerando a responsabilidade social da empresa, também evidenciada na DVA. O } \\
\text { resultado corrobora os estudos de Scherer (2006) e de Crippa e Coelho (2012). Contudo, } \\
\text { vão de encontro com os achados de Barros et al. (2013) e Martins et al. (2014). }\end{array}$ \\
\hline$\S 6^{-}$ & $\begin{array}{l}\text { De forma geral, os resultados mostram que o processo de mudanças do padrão contábil } \\
\text { no Brasil está trazendo conteúdo informacional às demonstrações financeiras em relação } \\
\text { ao mercado de capitais, ou seja, a exigência da DVA melhora a qualidade informacional } \\
\text { das demonstrações financeiras. Isso está em consonância com os resultados de Bartov et } \\
\text { al. (2005); Hung e Subramanyam (2007), Barth et al. (2008); Chalmers et al. (2008); } \\
\text { Morais e Curto (2009), Chalmers et al. (2009), Kadri et al. (2009) e Lima (2011), que } \\
\text { também encontraram melhoria do conteúdo informacional das demonstrações contábeis } \\
\text { após o processo de convergência às normas internacionais de contabilidade. }\end{array}$ \\
\hline$\S 7^{0}$ & $\begin{array}{l}\text { Ademais, é possível levantar a hipótese de que a DVA tem apresentado utilidade ao } \\
\text { investidor e sugerir que novos estudos sobre o conteúdo informacional sejam realizados, } \\
\text { aumentando o número de observações, bem como incluindo outras variáveis de controle } \\
\text { e análises que diferenciem as empresas estudadas, especialmente, quanto à adoção de } \\
\text { práticas socioambientais, à adoção de práticas de governança, ao setor ao qual pertence e } \\
\text { à forma de distribuição do valor adicionado. }\end{array}$ \\
\hline
\end{tabular}

